UNIVERSIDADE DE SÃO PAULO

INSTITUTO DE GEOCIÊNCIAS

\title{
EVOLUÇÃO DIAGENÉTICA DAS FORMAÇÕES PIRAMBÓIA E BOTUCATU (SISTEMA AQÜÍFERO GUARANI) NO ESTADO DE SÃO PAULO
}

\author{
Ana Lúcia Desenzi Gesicki
}

Orientador: Prof. Dr. Paulo César Fonseca Giannini

TESE DE DOUTORAMENTO

Programa de Pós-Graduação em Geologia Sedimentar

SÃO PAULO

2007 
Autorizo a reprodução e divulgação total ou parcial deste trabalho, por qualquer meio convencional ou eletrônico, para fins de estudo e pesquisa, desde que citada a fonte.

Ficha catalográfica preparada pelo Serviço de Biblioteca e Documentação do Instituto de Geociências da Universidade de São Paulo

Gesicki, Ana Lúcia Desenzi

Evolução diagenética das formações Pirambóia e Botucatu

(Sistema Aqüífero Guarani) no Estado de São Paulo /

Ana Lúcia Desenzi Gesicki - São Paulo, 2007.

175 fls.: il

Tese (Doutorado): IGc/USP

Orient.: Giannini, Paulo César Fonseca

1. Diagênese 2. Sistema Aqüífero Guarani 3. Petrofácies

4. Hidrogeoquímica I. Título 
Aos meus queridos

Camila e Jon 


\section{AGRADECIMENTOS}

Devo sinceros agradecimentos ao Prof. Dr. Paulo César Fonseca Giannini, orientador e amigo, que viabilizou e contribuiu em todas as etapas do estudo, pelo apoio, atenção e disponibilidade, mas principalmente pelo aprendizado em sedimentologia e pela agradável convivência no campo, na sala de aula e em todos os momentos.

Agradeço à FAPESP pelo financiamento deste estudo, através de projeto de auxílio à pesquisa concedido ao Prof. Dr. Paulo César Fonseca Giannini (processo 03/08911-0), e à CAPES pela concessão de bolsa de doutorado.

Ao Prof. Dr. Reginaldo Antonio Bertolo, amigo de longa data, e ao Prof. Dr. Ricardo Hirata, agradeço pelo indispensável apoio nas etapas de levantamento de campo e de interpretação dos dados hidrogeoquímicos do aqüífero. Estou em débito com Isaac Jamil Sayeg, do Laboratório de Microscopia Eletrônica do IGc-USP (LabMev), e acredito não ser capaz de retribuir à extrema atenção que me foi dispensada durante toda a longa fase de realização dos trabalhos de laboratório.

Aos bolsistas estagiários do Laboratório de Sedimentologia (LabSed) e do Laboratório de Petrografia Sedimentar (LabSed) do IGc-USP, agradeço pela ajuda e dedicação nas etapas de preparação de amostras, de análise de imagens digitais de lâmina e de captação de imagens de MEV, em especial Vitor Aguiar, Adriano de Souza, Rodolfo Marinho, Cecília Blanco, Bruna Marquezini, Jaqueline Ronque, Priscila Cachucho e Rebeca Cardoso. Agradeço à técnica do LabSed, Elaine Sinfronio, pelo suporte ao uso dos equipamentos deste laboratório.

Sou grata também aos colegas pós-graduandos que me acompanharam nos levantamentos de campo, Charazéd Morenghi, Milene Fornari, André Stern, Alexandra Sugohussof, Ingo Wanfried e ao Prof. Dr. André Sawakuchi. Aos alunos do curso de Geologia, Weder Portugal, Daiane Curti e Rogério Brandi, agradeço pela contribuição no laboratório e no campo.

Agradeço ao DAEE (Departamento de Água e Energia Elétrica de São Paulo) e à Superintendência Regional de São Paulo da CPRM (Serviço Geológico do Brasil) por terem permitido o acesso a suas litotecas e aos acervos de dados de poços de captação de água subterrânea. Sou grata pelo apoio recebido, em Araraquara, dos geólogos José Luiz Mendonça, Marco Aurélio Carvalho e Cícero Azzi. À SABESP, pela 
autorização de coleta de água subterrânea em poços de abastecimento no interior do estado.

Agradeço imensamente o Dr. Almério França pelo gentil empréstimo de seções delgadas de sua coleção, de amostras de arenitos das formações Pirambóia e Botucatu provenientes de poços de petróleo da Bacia do Paraná.

Com relação aos funcionários e técnicos do IGc-USP, gostaria de registrar especial agradecimento a Luiz Nogueira e Paulo Morgato (seção de laminação); Durval de Oliveira e Marciano Marques (seção de transportes); Ana Paula Cabanal e Magali Rizzo (seção de pós-graduação).

Ao DNPM (Departamento Nacional de Produção Mineral), na figura do geólogo Enzo Luís Nico Jr., sou grata pela compreensão e apoio na fase conclusiva deste trabalho.

Ao meu querido Paulo Boggiani, pelo suporte, incentivo, companheirismo, paciência e dedicação. Dedico-Ihe este trabalho com muito carinho. 


\section{RESUMO}

GESICKI, A.L.D. Evolução diagenética das formações Pirambóia e Botucatu (Sistema Aqüífero Guarani) no Estado de São Paulo. 2007. 175 p. Tese (Doutorado) - Instituto de Geociências, Universidade de São Paulo.

A investigação das rochas das formações Pirambóia e Botucatu em subsuperfície foi realizada através da revisão, coleta e análise de amostras de calha de poços de captação de água no interior do Estado de São Paulo, além de dados de poços de petróleo da Bacia do Paraná, com o objetivo de delinear a evolução diagenética destas unidades e identificar possíveis controles faciológicos do Sistema Aqüífero Guarani no estado. Segundo modelo genético definido na faixa de afloramentos destas unidades no centro-leste do Estado de São Paulo, as rochas da Formação Pirambóia são associadas ao desenvolvimento de sistema eólico úmido e a Formação Botucatu a sistema eólico seco. Através da análise petrográfica de amostras de calha e testemunhos de sondagem, foram definidos dois grupos de petrofácies, o de quartzo-arenitos (QA) e o de arenitos feldspáticos (FA), subdivididos nos tipos 1 e 2 devido, respectivamente, à presença ou ausência de cutícula argilo-ferruginosa. A Formação Pirambóia é caracterizada por petrofácies predominantemente feldspáticas e a Formação Botucatu por petrofácies essencialmente quartzosas. Ambas unidades apresentam arcabouço aberto e feições de compactação física e química pouco a moderadamente eficiente. A principal fase de geração de porosidade secundária das formações está associada à configuração do sistema aqüífero, com invasão profunda de águas meteóricas a partir da zona de afloramento das unidades. O Sistema Aqüífero Guarani (SAG) é caracterizado por três grupos de águas subterrâneas, divididas em cinco áreas hidroquímicas no Estado de São Paulo, segundo as condições de confinamento das rochas. A evolução química do SAG representa a interação da água com o substrato de rochas modificadas por eventos diagenéticos pretéritos. Devido às características faciológicas das unidades e ao histórico de soterramento relativamente pouco profundo, as modificações diagenéticas não foram eficientes a ponto de influenciar drasticamente as características permo-porosas originais das rochas. A Formação Pirambóia apresenta evolução diagenética mais complexa, devido ao histórico de soterramento mais longo, e constitui domínio com maior heterogeneidade no SAG. Nesta formação, são encontrados horizontes preferenciais de cimentação carbonática tardia, na interface de contato superior com a Formação Botucatu, e 
intercalações pelíticas no domínio inferior da unidade. A Formação Botucatu é preferencialmente porosa e suas modificações diagenéticas referem-se a neoformação incipiente de argilominerais e precipitação de cimentos de quartzo e feldspato nas porções de maior soterramento da bacia.

Palavras-chave: Diagênese; Sistema Aqǘfero Guarani; Formação Pirambóia; Formação Botucatu; Petrofácies; Hidrogeoquímica. 


\section{ABSTRACT}

GESICKI, A.L.D. Evolução diagenética das formações Pirambóia e Botucatu (Sistema Aqüífero Guarani) no Estado de São Paulo. 2007. 175 p. Tese (Doutorado) - Instituto de Geociências, Universidade de São Paulo.

The purpose of this study consists of subsurface investigation of Pirambóia and Botucatu formations (Late Permian to Early Cretaceous of Paraná Basin) with revision, sampling and petrography of cutting samples from water and petroleum wells in São Paulo State. The main aim was delineate the diagenetic evolution of these formations and identify possible faciologic controls in Guarani Aquifer System. The depositional model of Pirambóia and Botucatu formations in outcrop domain of the São Paulo State is associated to, respectively, warm aeolian system and dry aeolian system. Sedimentary petrography was the basic analytical tool. Two main petrofacies was defined, the quartz sandstones (QA) and the feldspathic sandstones (FA). The presence or absence of thin clay coats demarks the 1 and 2 petrofacies subtypes, respectively. The Pirambóia Formation is mainly composed of feldspathic sandstones related to weak mechanical and chemical compaction and low packing indexes $(<40 \%)$. The diagenetic components recognized were infiltrated clays, feldspathic cement and neoformed clays (smectite and mixed layer illite/smectite) during eodiagenesis; mesogenetic quartz and bitumen cements, neoformed clays (caolinite) and precipitation of calcite cement during telodiagenesis. The generation of secondary porosity is associated to aquifer system configuration, due to deep invasion of meteoric water from the outcrop belt (recharge zone). The Botucatu Formation consists of predominant porous quartz sandstones with late intersticial calcite and chalcedony cements restricted to aquifer margins. Sandstone framework is typically open (IP<35\%) and displays some mechanical and chemical compaction preferentialy to deeper basin, in the western São Paulo State. The main diagenetic componets are: eogenetic vadose infiltrated clays; incipiently neoformed clayminerals and quartz cement during mesodiagenesis; secondary porosity features, with mineral dissolution and feldspar replacing by claymineral (caolinite) during telodiagenesis. The Guarani Aquifer System (GAS) is characterized by three main geochemical groups of groundwater, divided in five hydrogeochemical areas, according to confinement conditions of the rocks. The hydrochemical evolution of the Guarani Aquifer System represents the water interaction with rock modified by 
previous diagenetic alterations. However, the efficiency of the diagenetic transformations was not enough to hardly changed the original high porosity and permeability of the rocks. The more complex Pirambóia Formation diagenetic evolution relates to longer buried history and to more heterogeneous faciologic composition (fine grained beds in the lower unity). The upper Pirambóia Formation presents the main calcite cemented domain of the aquifer. The Botucatu Formation is porous in almost whole aquifer extension in São Paulo.

Keywords: Diagenesis; Guarani Aquifer System; Pirambóia Formation; Botucatu Formation; Petrofacies; Hydrogeochemistry. 


\section{SUMÁRIO}

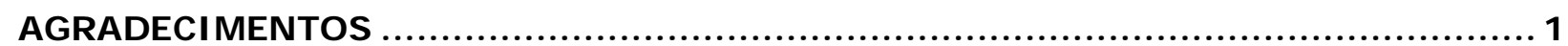

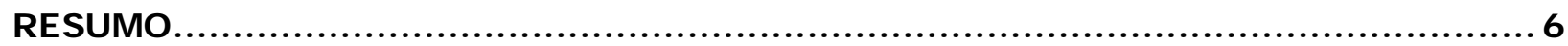

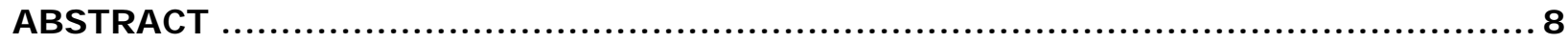

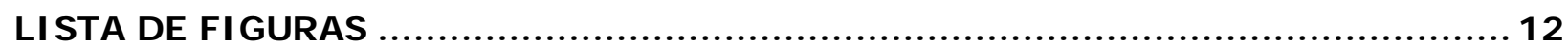

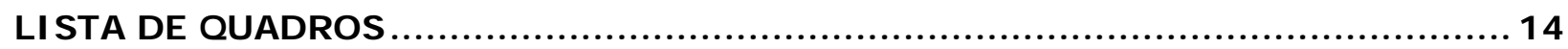

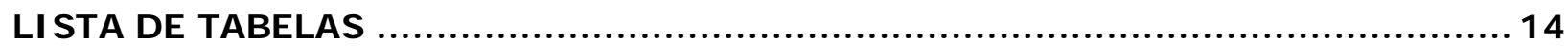

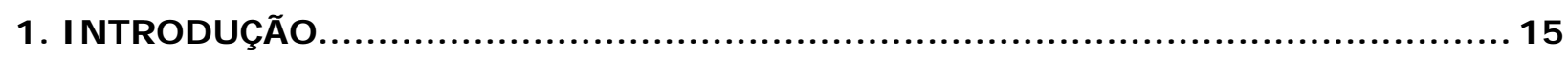

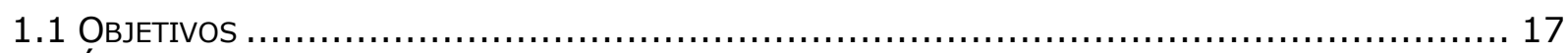

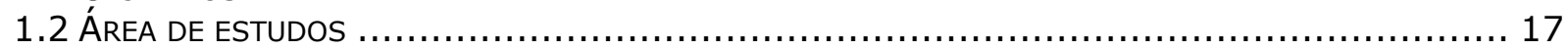

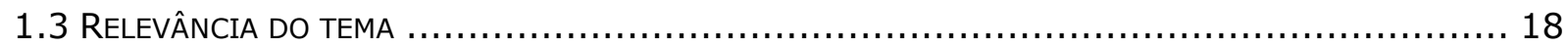

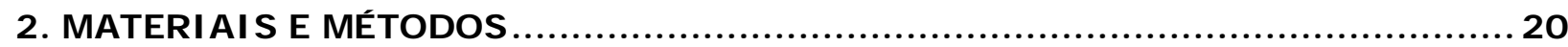

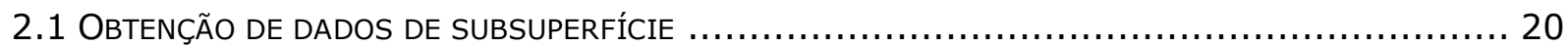

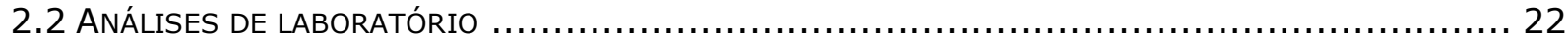

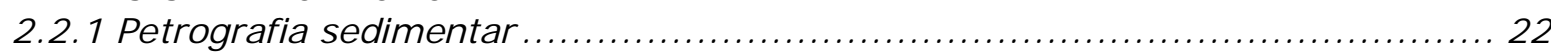

Preparação e confeç̧ão de seções delgadas ............................................................ 22

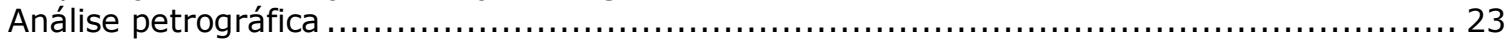

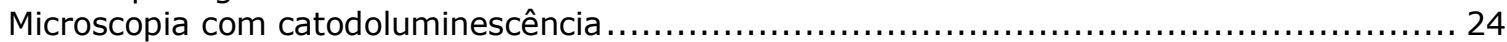

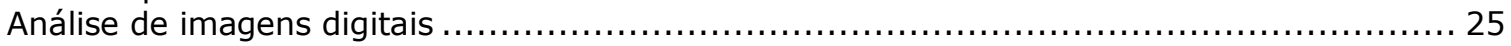

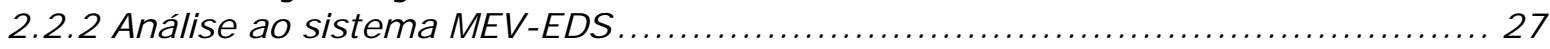

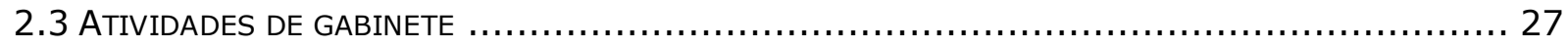

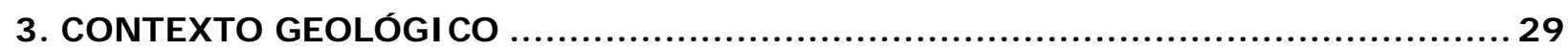

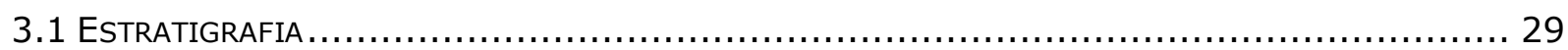

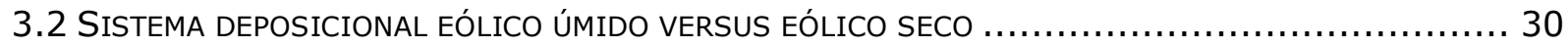

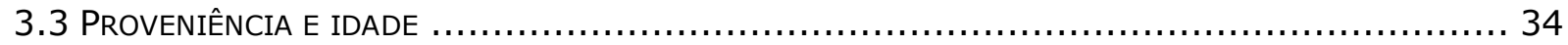

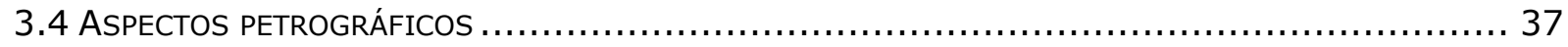

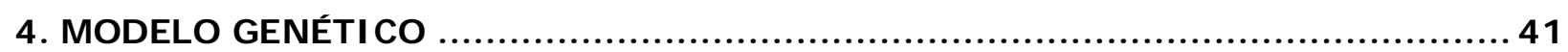

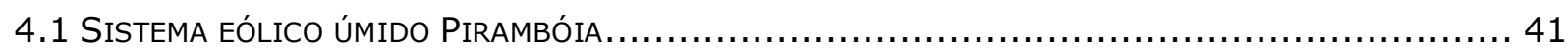

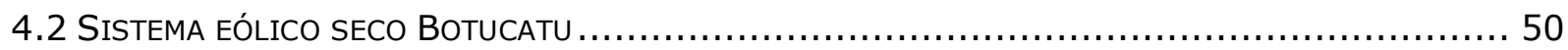

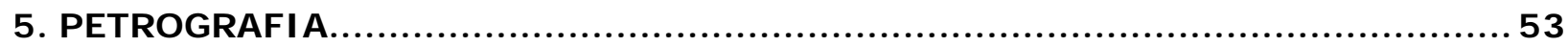

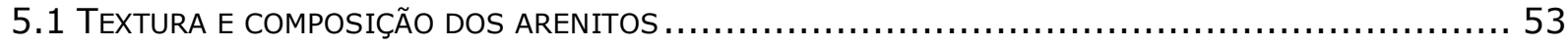

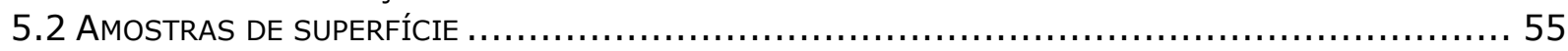

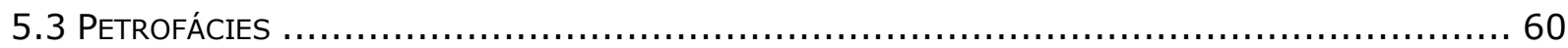

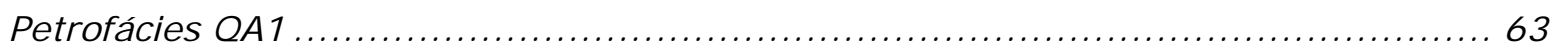

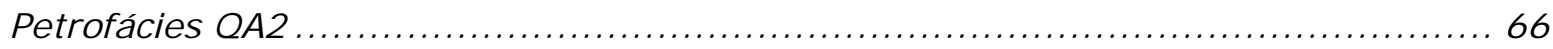

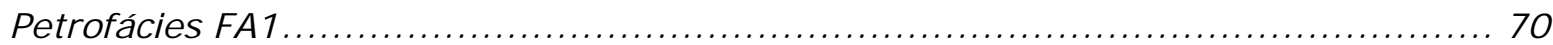

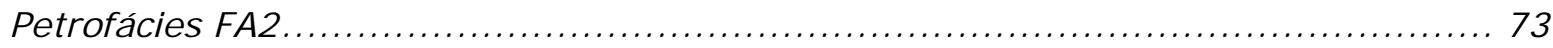

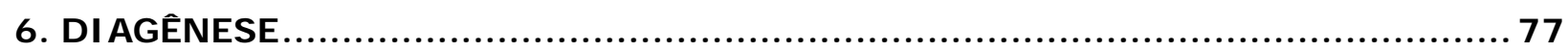

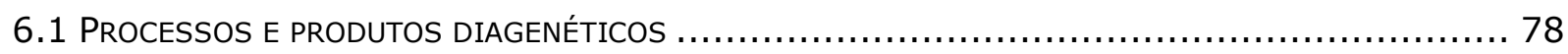

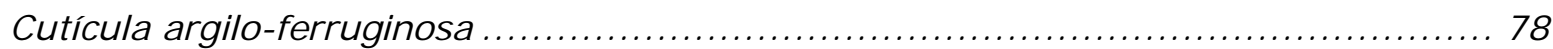

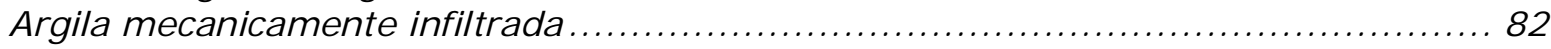

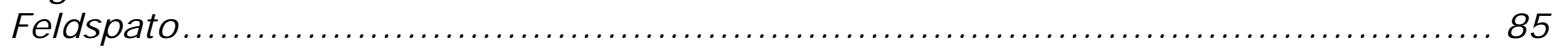

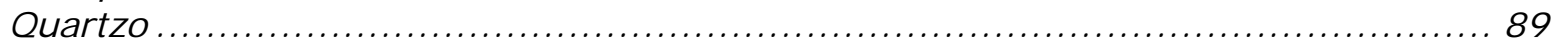

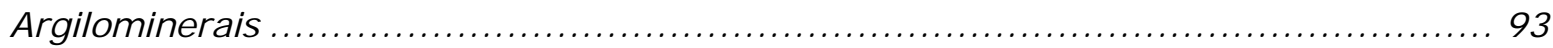

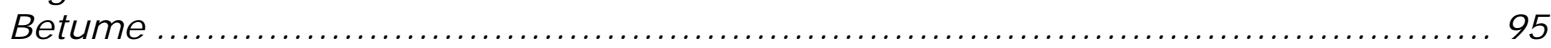

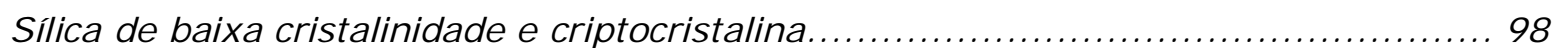

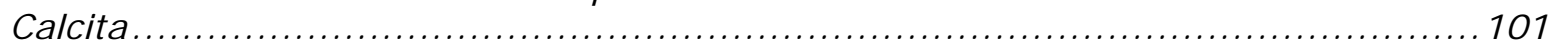


Compactação mecânica e química ...

Geração de porosidade secundária

Outros cimentos

6.2 SEQÜÊNCIA DE EVENTOS DIAGENÉTICOS

7. AS FORMAÇÕES PI RAMBÓI A E BOTUCATU EM SUBSUPERFÍ CIE 112

7.1 DiSTRIBUIÇÃO DAS UNIDADES EM SUBSUPERFÍCIE 113

8. O SI STEMA AQUÍ FERO GUARANI (SAG) EM SP 119

8.1 DADOS HIDROGEOQUÍMICOS E ISOTÓPICOS RECENTES 122

8.2 MODELO HIDROGEOQUÍMICO CONCEITUAL

9. CONSI DERAÇÕES SOBRE A DI AGÊNESE E A EVOLUÇÃO QUÍ MI CA DO SAG ...... 135

9.1 EODIAGÊNESE 136

9.2 MESODIAGÊNESE 137

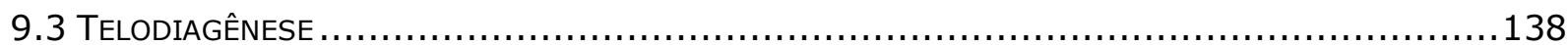

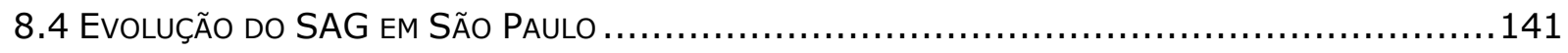

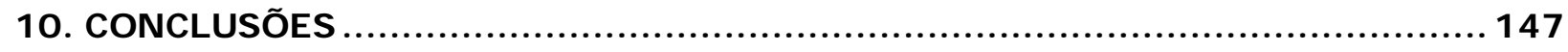

REFERÊNCI AS BI BLI OGRÁFI CAS............................................................ 152

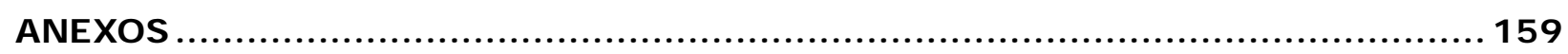




\section{LISTA DE FIGURAS}

Figura 1.1 - Localização e esboço geológico da área de estudos.

Figura 1.2 - Localização dos afloramentos e dos poços de captação de água e de petróleo utilizados neste estudo.

Figura 3.1 - Coluna litoestratigráfica da Bacia do Paraná. Baseada em Milani et al. (1994) e Matos (1995).

Figura 4.1 - Séries de estratificações cruzadas acanaladas da fácies Aca.

Figura 4.2 - Arenitos muito finos com estratificação de ângulo de mergulho baixo da fácies

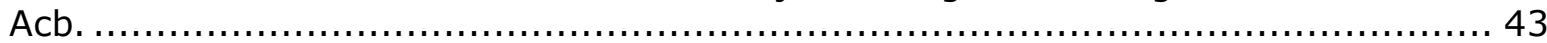

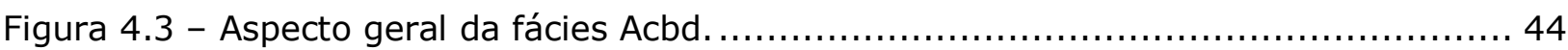

Figura 4.4 - Arenitos muito finos sílticos com estratificação heterolítica da fácies Acbl.. .. 45

Figura 4.5 - Fácies Acp preenchendo paleocanal de superfície basal irregular. 46

Figura 4.6 - Arenitos finos maciços da fácies Am, que podem ocorrer sobrepostos à fácies de brecha intraformacional............................................................... 47

Figura 4.7 - Visão geral (fotografias A e B) dos arenitos conglomeráticos da fácies ACg, atribuído a depósitos de rios entrelaçados do sistema Pirambóia Superior.............. 48

Figura 4.8 - Passagem transicional entre o sistema marinho raso Passa Dois e sistema eólico úmido Pirambóia................................................................... 49

Figura 4.9 - Arenitos finos da fácies AFca, do sistema eólico seco Botucatu................. 51

Figura 5.1 - Composição mineralógica do arcabouço dos arenitos das formações Pirambóia e Botucatu.

Figura 5.2 - Relação entre conteúdo de feldspato do arcabouço dos arenitos e profundidade

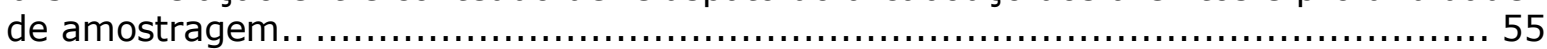

Figura 5.3 - Arenitos finos a médios da fácies eólica (duna) do sistema eólico Pirambóia.. 57

Figura 5.4 - Arenitos finos a médios da fácies eólica (interdunas) do sistema eólico Pirambóia.

Figura 5.5 - Arenitos médios a grossos da fácies flúvio-eólica (fluvial) da porção superior do sistema eólico Pirambóia.

Figura 5.6 - Arenitos muito finos a finos da fácies eólica (dunas) do sistema eólico Botucatu.

Figura 5.7 - Arenitos finos de fácies eólicas (duna) do sistema eólico Botucatu com cimento silicoso.

Figura 5.8 - Aspectos texturais e diagenéticos da petrofácies QA1........................65 65

Figura 5.9 - Aspectos texturais e diagenéticos da petrofácies QA2........................6 68

Figura 5.10 - Aspectos texturais e diagenéticos da petrofácies QA2f........................69

Figura 5.11 - Aspectos texturais e diagenéticos da petrofácies FA1 ........................ 72

Figura 5.12 - Aspectos texturais e diagenéticos da petrofácies FA2 . ...................... 74

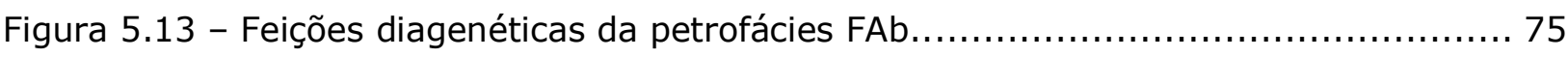

Figura 6.1 - Feições texturais das cutículas argilosas precoces.. .......................... 79

Figura 6.2 - Prováveis interestratificados esmectita/illita.............................. 82

Figura 6.3 - Aspectos texturais das argilas mecanicamente infiltradas.. ................... 84

Figura 6.4 - Relação entre o conteúdo de cimento de feldspato com a profundidade e com o conteúdo de feldspato detrítico do arcabouço.............................................. 85

Figura 6.5 - Aspectos texturais dos cimentos de feldspato............................. 86 
Figura 6.6 - Distribuição do cimento de quartzo com a profundidade e sua relação com as

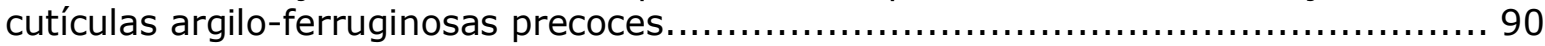

Figura 6.7 - Feições texturais do cimento de quartzo, o qual ocorre como crescimento secundário sintaxial.

Figura 6.8 - Substituição pseudomórfica de argilominerais em grãos de feldspato. ......... 94

Figura 6.9 - Cimento de betume nos arenitos da Formação Pirambóia. .................... 97

Figura 6.10 - Cimentos de sílica de baixa cristalinidade.................................... 100

Figura 6.11 - Distribuição heterogênea do cimento de calcita com a profundidade.........102

Figura 6.12 - Feições de compactação mecânica nos arenitos porosos das formações Pirambóia e Botucatu.

Figura 6.13 - Avaliação quantitativa da perda de porosidade dos arenitos das formações Pirambóia e Botucatu.

Figura 6.14 - Avaliação relativa da influência da compactação e cimentação na perda de

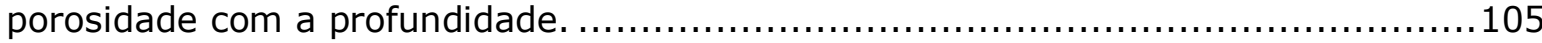

Figura 6.15 - Avaliação da perda de porosidade em comparação a parâmetros deposicionais e diagenéticos.

Figura 6.16 - Tipos de porosidade secundária reconhecidos nas unidades estudadas.

Figura 6.17 - Distribuição da macroporosidade total e da porosidade secundária em relação à profundidade de ocorrência.

Figura 6.18 - Cimento de óxido de ferro na forma de franja poro-envolvente e cimento de analcima intersticial.

Figura 6.18 - Seqüência paragenética das formações Pirambóia e Botucatu.

Figura 7.1 - Mapa de contorno estrutural do topo da Formação Botucatu em São Paulo. Isóbatas expessas em metros

Figura 7.2 - Mapa de contorno estrutural do topo da Formação Pirambóia em São Paulo. Isóbatas expressas em metros.

Figura 7.3 - Mapa de isópacas das rochas que encobrem as formações Pirambóia e Botucatu em São Paulo.

Figura 7.4 - Mapa de isópacas da Formação Botucatu em São Paulo......................116

Figura 7.5 - Mapa de isópacas da Formação Pirambóia em São Paulo.

Figura 7.6 - Mapa de isópacas da porção superior da Formação Pirambóia em São Paulo.117

Figura 8.1 - Mapa potenciométrico do SAG no Estado de São Paulo. Baseado em Takahashi (2005)

Figura 8.2 - Mapas de isoconcentrações de cálcio, sódio + potássio, sulfato e cloreto do SAG em São Paulo. Extraído de Portugal (2006).

Figura 8.3 - Mapas de distribuição dos índices hidroquímicos $\mathrm{Ca} /\left(\mathrm{Ca}+\mathrm{SO}_{4}\right)$ e $\mathrm{SiO}_{2} /(\mathrm{Na}+\mathrm{K}$

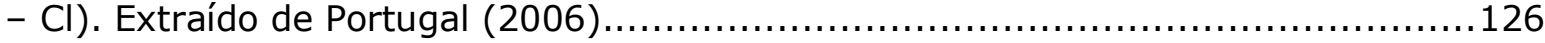

Figura 8.4 - Mapas de distribuição dos valores da razão entre bicarbonato e sílica e do índice de saturação teórico da calcita na água. Extraído de Portugal (2006).

Figura 8.5 - Diagramas de estabilidade de aluminossilicatos, em relação à concentração de cálcio, sódio e potássio da água. Extraído de Portugal (2006).

Figura 8.6 - Mapa de isócronas do SAG, baseadas em datação ${ }^{14} \mathrm{C}$. Extraído de Portugal (2006). As setas indicam o sentido de fluxo advectivo do aqǘf́ero.

Figura 8.7 - Mapa potenciométrico do SAG em Mato Grosso do Sul, segundo proposta de Gastmans \& Chang (2005).

Figura 8.8 - Mapa com a distribuição das áreas hidrogeoquímicas do SAG, segundo modelo conceitual proposto por Portugal (2006).

Figura 9.1 - Quadro diagenético evolutivo das formações Pirambóia (PIR) e Botucatu (BOT) no Estado de São Paulo. 
Figura 9.2 - Evolução hidráulica do SAG e principais fronteiras de modificação química das

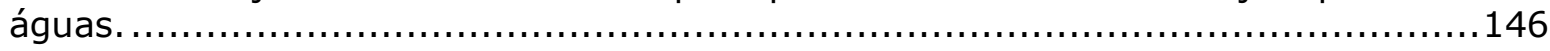

\section{LISTA DE QUADROS}

Quadro 4.1 - Resumo das fácies sedimentares e processos deposicionais dos sistemas eólicos Pirambóia e Botucatu (baseado em Giannini 2001) ....

Quadro 5.1 - Características petrográficas dos domínios genéticos dos sistemas eólicos

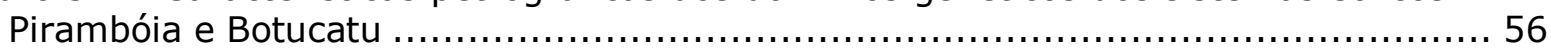

Quadro 5.2 - Características da petrofácies das formações Pirambóia e Botucatu. .......... 61

Quadro 8.1 - Relação dos poços de amostragem de água (Portugal 2006). ...................123

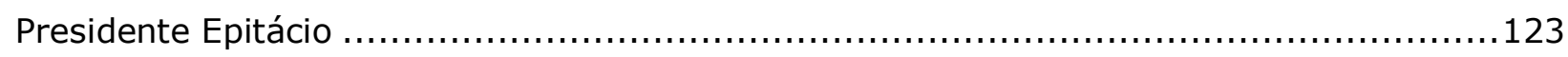

\section{LISTA DE TABELAS}

Tabela 5.1 - Parâmetros texturais dos arenitos das formações Pirambóia e Botucatu........ 53

Tabela 5.2 - Relação de poços e petrofácies reconhecidas em subsuperfície. 61 


\section{INTRODUÇÃO}

A petrografia de arenitos constitui ferramenta indispensável à análise da qualidade de reservatórios no setor exploratório da indústria de petróleo, por ser de baixo custo, relativamente precisa e da qual é possível obter uma série de informações essenciais, como identificar componentes deposicionais e diagenéticos e decifrar as muitas vezes complexas interações e modificações físico-químicas às quais a rocha foi submetida após a deposição. Aliada a outras ferramentas, pode fornecer elementos preditivos importantes à prospecção de reservatórios em bacias sedimentares.

A maior dificuldade e custo da localização e extração de petróleo, em comparação com a água subterrânea, e o valor de mercado do produto, justificam os maiores inestimentos e toda tecnologia de ponta utilizada pela indústria petrolífera. Mesmo diante deste fato, o segmento de produção de água subterrânea pode ser considerado modesto em excesso nos seus investimentos, especialmente quando se leva em conta que a água subterrânea é uma alternativa muitas vezes indispensável para abastecimento urbano e manutenção da vida nas cidades. As empresas que perfuram poços tubulares com profundidades maiores que $500 \mathrm{~m}$ detêm e aplicam maior tecnologia para prospecção e caracterização dos aqüíferos subterrâneos, principalmente ferramentas de investigação indireta (levantamentos geofísicos e perfilagem de poços). Porém, mesmo nesse caso, a especialidade dos profissionais da área é primordialmente em Hidrogeologia; e os hidrogeólogos privilegiam amplamente o estudo da água subterrânea em si e negligenciam a rocha. Visto que o sistema aqüífero por definição é composto pelo conjunto água e rocha (ou depósito sedimentar), no caso de aqüíferos porosos a sedimentologia deveria ser abordada em detalhe tanto quanto a hidrogeoquímica e a hidráulica.

Em aqüíferos porosos confinados, assim como em reservatórios profundos, poucas são as ferramentas de investigação direta da rocha. Nos poços de prospecção de petróleo, há a possibilidade de obtenção de testemunhos dos intervalos de interesse para estudos de sedimentologia, estratigrafia e petrofísica. Por sua vez, o método de perfuração dos poços de captação de água subterrânea é destrutivo e só é possível recuperar material de calha (sedimento desagregado), pois a testemunhagem da rocha torna a perfuração cara e demorada. O material de calha é descrito de forma expedita na boca do poço, com intuito de identificar os 
intervalos estratigráficos de interesse (intervalos produtores do aqüífero), e nem sempre é coletado, processado e arquivado de forma adequada.

Estudar amostras de calha de poços de captação de água subterrânea não é das tarefas mais fáceis. Não é à toa que ninguém se interesse em fazer petrografia de arenitos quando se estuda um aqüífero. Existe uma série de inconvenientes neste tipo de amostragem: sedimentos desagregados, mistura de intervalos estratigráficos, contaminação pela lama de perfuração, imprecisão da profundidade de amostragem, entre outros. No entanto, como será visto adiante neste trabalho, a petrografia de amostras de fragmentos de calha de poços de água, adotados certos critérios analíticos, torna-se viável, pois permite a caracterização da rocha em profundidade e fornece informações importantes sobre a faciologia das unidade sedimentares atravessadas pelo poço e sobre os componentes diagenéticos resultantes da interação rocha/água.

No caso específico do Sistema Aqüífero Guarani (SAG) no Estado de São Paulo, trata-se sem dúvida de um reservatório de qualidade excepcional, com ampla área de ocorrência de águas pouco salinizadas e valores elevados de vazão de poços, com produção de até $600 \mathrm{~m}^{3} / \mathrm{h}$ na sua porção confinada, situada no oeste do estado. Embora razoavelmente investigado quanto às características hidrogeológicas, pouco se conhece sobre suas rochas - os arenitos das formações Pirambóia e Botucatu - além da faixa de afloramentos. Este estudo pretende preencher esta lacuna de conhecimento e abrir nova frente de pesquisa do SAG, tendo em vista integrar a distribuição e composição da água com os modelos sedimentar e de evolução diagenética da rocha.

No início deste estudo, uma série de dúvidas serviu como guia para a investigação: o modelo genético deposicional das formações Pirambóia e Botucatu, que foi definido da zona aflorante, é o mesmo no centro da bacia? As distintas características faciológicas das formações Pirambóia e Botucatu geram alguma compartimentação no SAG? Estas formações apresentam variações composicionais de suas rochas do centro para a borda da bacia? A diagênese influenciou de alguma forma as características atuais do SAG? Como foi a evolução diagenética destas unidades?

Para tentar esclarecer estas questões, utilizou-se o material disponível dos poços de captação de água (amostras de calha e perfis) do Estado de São Paulo, além de raros testemunhos de sondagem e dados de poços de petróleo, sendo a ferramenta básica de análise a petrografia sedimentar. 


\subsection{Objetivos}

Os principais objetivos desta Tese são:

- estudar a constituição faciológica das formações Pirambóia e Botucatu em superfície e subsuperfície no Estado de São Paulo;

- caracterizar as feições diagenéticas dos arenitos das formações Pirambóia e Botucatu no Estado de São Paulo, através do estudo integrado das características microscópicas de amostras de subsuperfície e de superfície, utilizando a petrografia sedimentar como ferramenta básica de análise;

- delinear a cronologia relativa dos eventos diagenéticos que afetaram os sedimentos das formações Pirambóia e Botucatu;

- identificar as variações diagenéticas das sucessões sedimentares e os fatores que influenciam esta variação;

- analisar a distribuição espacial das unidades em subsuperfície e identificar seus limites estratigráficos.

- oferecer subsídios para avaliação da qualidade do aqüífero sedimentar através da análise das heterogeneidades faciológicas e diagenéticas, as quais tenham influência direta na distribuição da porosidade e características hidroquímicas do aqüífero.

\section{2 Área de estudos}

A área de estudos compreende a extensão das formações Pirambóia e Botucatu no Estado de São Paulo, desde a faixa de afloramento das unidades na região centro-leste do estado, até sua porção confinada por sob rochas vulcânicas da Formação Serra Geral e depósitos da Bacia Bauru, no sentido oeste (Figura 1.1).

A área de afloramentos destas unidades constitui faixa de direção aproximada NNE-SSW, com largura variável desde cerca de $4 \mathrm{~km}$, no sudoeste do estado próximo ao limite com o Paraná (região entre as cidades de Fartura e Piraju), até o máximo de aproximadamente $130 \mathrm{~km}$, no centro-leste paulista (região balizada pelas cidades de Ribeirão Bonito e Rio Claro). 
As espessuras em superfície das formações Pirambóia e Botucatu nas áreas de exposição no estado são de no máximo 270 m e 150 m, respectivamente (Soares 1975, Caetano-Chang 1997), enquanto que em subsuperfície a espessura máxima conhecida das duas formações em conjunto é de 437 m, no poço de Araçatuba (2-AR-01-SP).

No domínio oeste do Estado de São Paulo, estas unidades encontram-se subjacentes a até quase 2000 m de rochas vulcânicas da Formação Serra Geral, sedimentos cretácicos da Bacia Bauru, e depósitos sedimentares mais jovens.

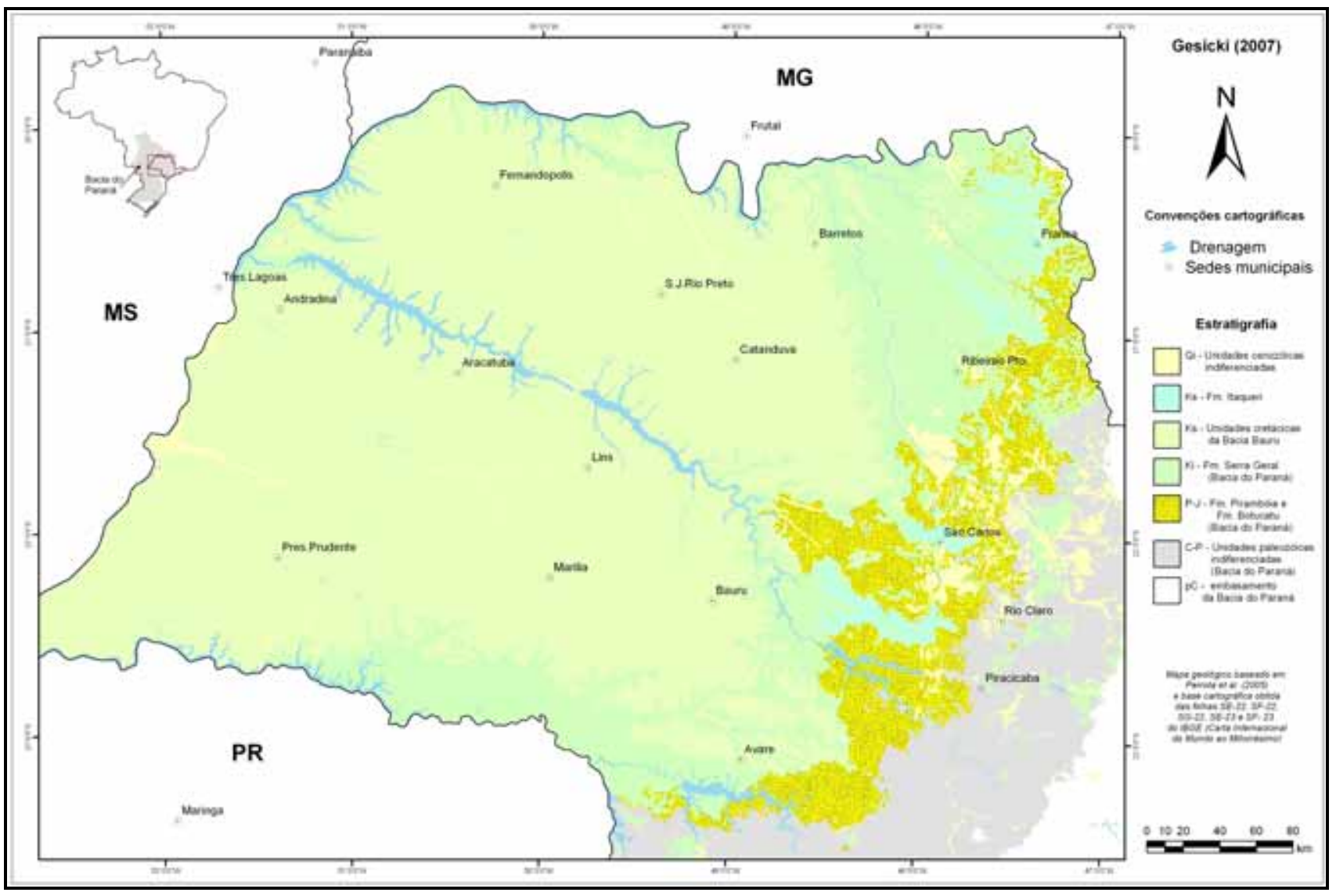

Figura 1.1 - Localização e esboço geológico da área de estudos.

\subsection{Importância dos estudos sedimentológicos das rochas do SAG}

A escassez e poluição acelerada dos recursos hídricos superficiais têm ampliado o interesse da sociedade pelo uso e proteção dos mananciais subterrâneos. A despeito da sua extensão transfronteiriça, é no Estado de São Paulo, a região mais populosa e com maior índice de industrialização, que o Aqüífero Guarani é mais intensamente utilizado e, por conseqüência, concentra maior número de dados de poços tubulares. São mais de 800 poços profundos 
perfurados para captação de água subterrânea deste aqüífero no estado, cerca de 350 deles destinados ao abastecimento público (Chang 2006).

O Sistema Aqüífero Guarani é um sistema de origem complexa, o qual não pode ser restringido apenas ao aspecto hidrogeológico. A qualidade do aqüífero depende das características sedimentares dos arenitos, que por sua vez dependem das condições deposicionais, modificações diagenéticas, compartimentação tectônica e, por fim, da interação das águas de infiltração com a rocha e das condições climáticas reinantes na área de recarga.

Apesar da importância do Sistema Aqüífero Guarani como fornecedor de água subterrânea, a caracterização diagenética das rochas das formações Pirambóia e Botucatu é um aspecto que sempre foi abordado de forma subordinada nos diversos estudos faciológicos e estratigráficos desenvolvidos sobre estas unidades na zona de afloramentos e praticamente ignorado nos estudos hidrogeológicos do aqüífero.

Trabalhos específicos de petrografia das rochas das formações Pirambóia e Botucatu restringem-se a amostras de superfície, obtidas na faixa de afloramento das unidades nos estados de São Paulo e Paraná (Carvalho 1954, Paraguassu 1968, Wu \& Soares 1974, Wu \& Caetano-Chang 1992a) e visaram, sobretudo, à caracterização textural e de proveniência dos sedimentos. Trabalhos mais recentes, com abordagem diagenética, foram elaborados por Caetano-Chang (1997), sobre a Formação Pirambóia estudada através de amostras de superfície e de poços na região de Anhembi, e por França et al. (2003), sobre a Formação Botucatu em subsuperfície.

O principal desafio deste estudo residiu na integração do conhecimento dos aspectos sedimentares das formações Pirambóia e Botucatu, através da análise de dados de supefície e subsuperfície, com as características hidrogeológicas do Sistema Aqüífero Guarani no Estado de São Paulo. Pretende-se demonstrar aqui a necessidade de investigação integrada da água e da rocha para o conhecimento e uso racional de um aqüífero. 


\section{MATERIAIS E MÉTODOS}

No presente estudo, foram analisados dados e amostras das formações Pirambóia e Botucatu obtidos em levantamentos de campo, nas áreas de exposição no leste do estado, e em consulta a litotecas e banco de dados de órgãos públicos. O material coletado foi submetido à análise petrográfica em microscópio ótico e eletrônico e análise de imagens digitais.

\subsection{Obtenção de dados de subsuperfície}

A principal fonte de dados de subsuperfície deste estudo consiste de poços tubulares para captação de água subterrânea, cujos projetos foram realizados pelo DAEE (Departamento de Águas e Energia Elétrica) e pela CPRM (Serviço Geológico do Brasil), os quais atingiram as formações Botucatu e Pirambóia no Estado de São Paulo. Estas duas instituições dispõem de litotecas, ambas na cidade de Araraquara (SP), onde estão armazenadas amostras de calha de cada poço executado, colhidas a cada $2 \mathrm{~m}$ de perfuração. Além deste material, foram obtidos os relatórios de poço, os quais possuem dados estratigráficos, hidrogeológicos e de perfilagem geofísica (raios gama, resistividade, potencial espontâneo, calliper e, eventualmente, perfil sônico).

Foram revisados 76 poços da litoteca do DAEE e 28 poços da litoteca da CPRM (Figura 1.2), com descrição das amostras de calha quanto a cor e aspectos texturais como granulometria, tipo de cimento, seleção e arredondamento dos grãos, com vista à diferenciação dos intervalos estratigráficos Botucatu e Pirambóia.

Grande parte das amostras de calha disponível não possibilita a obtenção de fragmentos íntegros ou "verdadeiros" da rocha perfurada. Devido ao processo destrutivo de perfuração, a recuperação da rocha porosa geralmente resulta em areias desagregadas ou aglomerados artificiais da areia com a lama de perfuração. Amostras íntegras da rocha foram obtidas preferencialmente em horizontes cimentados por carbonato ou sílica. Desta forma, dos 104 poços revisados, foram obtidas amostras de fragmentos de rocha em apenas 30, o que totaliza cerca de 130 amostras. Em pelo menos três poços (Barretos, Batatais e Fernandópolis), pôde ser realizada amostragem razoavelmente representativa das duas formações ao longo de um mesmo perfil de poço. 


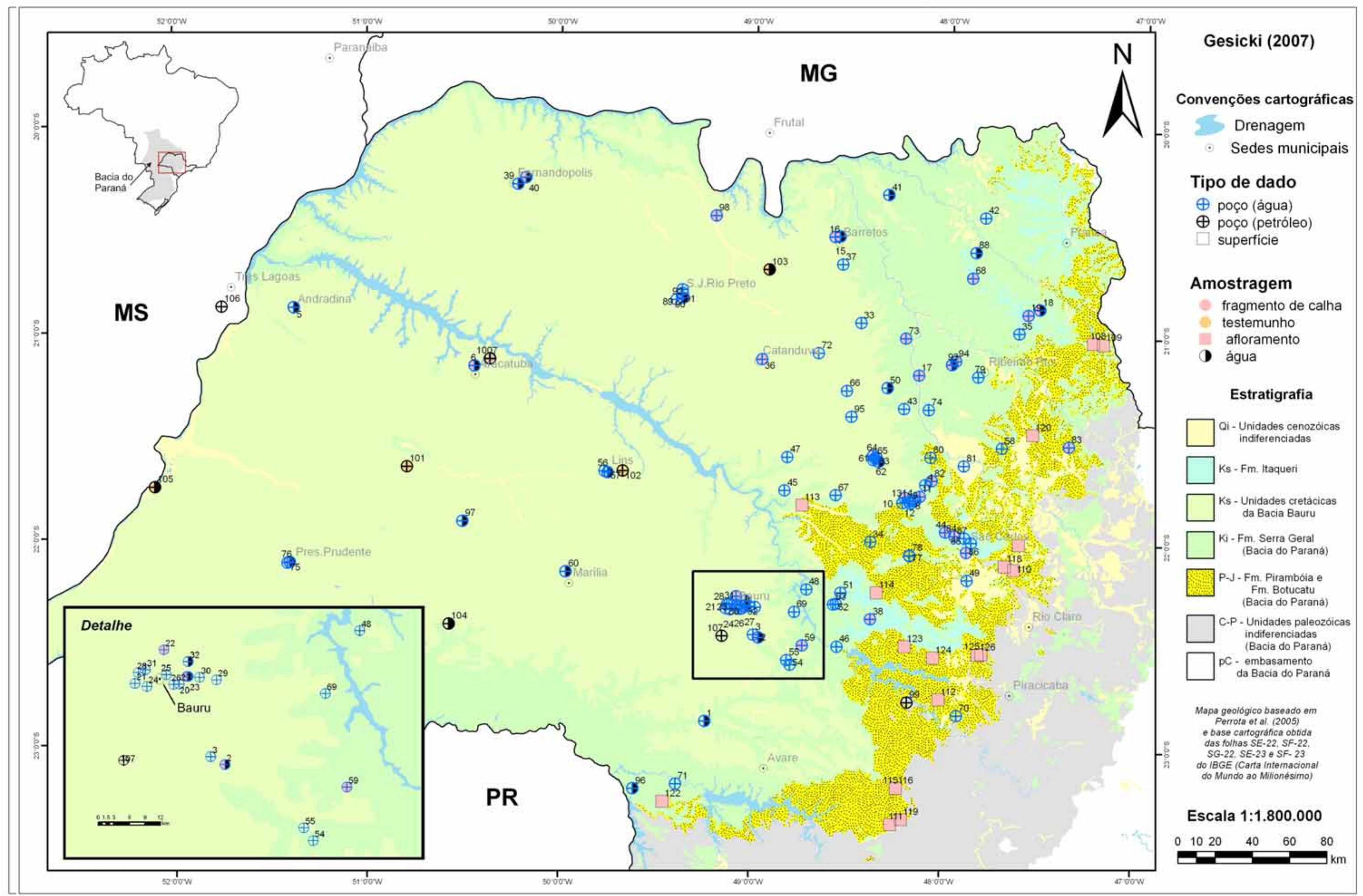

Figura 1.2 - Localização dos afloramentos e dos poços de captação de água e de petróleo utilizados neste estudo. Vide relação na Tabela 1 (Anexos). 
Além dos poços de captação de água subterrânea, procurou-se obter amostras de calha e de testemunhos de sondagem de poços de prospecção de petróleo perfurados pela Petrobras e Paulipetro na Bacia do Paraná. Infelizmente este material não esteve acessível para este estudo, mesmo após três anos de insistentes pedidos junto à ANP (Agência Nacional do Petróleo), detentora dos dados públicos da Bacia do Paraná, para que a Petrobras fornecesse as referidas amostras. Esta lacuna foi parcialmente sanada com o gentil empréstimo de seções delgadas de amostras de cinco poços da Bacia do Paraná, pertencentes à coleção pessoal do Dr. Almério $B$. França, além de uma amostra de testemunho de sondagem do poço de Presidente Epitácio (2-PE-01-SP), disponível na coleção didática do IGc-USP.

\subsection{Análises de laboratório}

\subsubsection{Petrografia sedimentar}

\section{Preparação e confecção de seções delgadas}

Antes de serem encaminhadas à laminação, as amostras de calha (subsuperfície) e de superfície coletadas passaram por processo de impregnação com resina colorida, cuja finalidade é ressaltar a porosidade original dos sedimentos para a etapa seguinte de análise petrográfica, assim como soldar os fragmentos de calha que individualmente não podem ser laminados. Este processo consiste no gotejamento, numa câmara de vácuo, de uma mistura de resina epóxi, endurecedor, solvente (álcool etílico) e corante azul, nas proporções em massa 50:5:7:1, respectivamente, sobre o material disposto em porta-amostra de silicone, de modo que a mistura lentamente permeie toda a amostra, até encobrila. No caso de amostras de superfície, molda-se um prisma de cerca de $3 \mathrm{~cm} \times 3 \mathrm{~cm} \times 1 \mathrm{~cm}$ para ser colocado no porta-amostra.

As seções delgadas foram preparadas na espessura padrão de $30 \mu \mathrm{m}$, sem cobertura de lamínula, de modo a permitir sua posterior análise no sistema MEVEDS e por catodoluminescência. No total, confeccionaram-se 133 lâminas de amostras de calha, 11 de amostras de superfície e uma de amostra de testemunho de sondagem. 


\section{Análise petrográfica}

A análise petrográfica consistiu na caracterização textural, mineralógica e de feições diagenéticas dos litotipos principais das formações Pirambóia e Botucatu em seções delgadas. Os procedimentos de análise seguiram aqueles adotados no Laboratório de Petrografia Sedimentar do IGc-USP, através dos quais se divide a descrição petrográfica de rochas psamíticas em componentes deposicionais (arcabouço e matriz) e componentes diagenéticos (cimento e porosidade), segundo as seguintes etapas:

- quantificação dos componentes (arcabouço, matriz, cimento e poro) através da contagem de pelo menos 200 pontos espaçados regularmente (malha de $0,5 \times 0,5 \mathrm{~mm}$ ou $0,3 \times 0,3 \mathrm{~mm})$;

- descrição e quantificação relativa do arcabouço quanto à mineralogia (conteúdo percentual de quartzo, feldspato e fragmentos líticos), textura (granulometria modal e desvio padrão, grau de seleção, graus de arredondamento e de esfericidade) e petrotrama (segregação granular, empacotamento e imbricação);

- determinação das características texturais do arcabouço (granulometria média e modal, desvio padrão e grau de seleção), através da medição do eixo maior aparente de pelo menos 100 grãos de cada fragmento de calha. O grau de seleção é dado pelo valor do desvio padrão da medida do eixo maior, transformado para a escala phi (Folk 1965);

- determinação do índice de proximidade de empacotamento $\left(\mathrm{IP}_{\mathrm{Kp}}\right)$ de Kahn (1956);

- descrição e quantificação da matriz quanto à mineralogia, textura e natureza (matriz deposicional ou diagenética);

- descrição e quantificação do cimento quanto à mineralogia, textura e relações espaciais com o arcabouço e espaço poroso;

- caracterização das interrelações dos componentes deposicionais e diagenéticos, como tipos de contato entre grãos do arcabouço (avaliação da compactação mecânica e química) e entre arcabouço e cimento;

- descrição dos tipos de porosidade secundária presentes, conforme classificação de Schmidt \& McDonald (1979); 
- determinação da maturidade textural e mineralógica da rocha segundo Folk (1968);

- classificação petrográfica de arenitos segundo Dott (1964) e Folk (1968);

- individualização de petrofácies.

A análise ao microscópio foi antecedida de descrição das feições macroscópicas das amostras, como cor, estruturas sedimentares e presença de cimento, além da identificação da fácies sedimentar correspondente, no caso de amostras de superfície. Para as amostras de calha, além da classificação petrográfica, elaborou-se classificação de petrofácies através da individualização de litologias com características texturais e diagenéticas específicas. A estas petrofácies, procurou-se associar tentativamente as fácies sedimentares das formações Pirambóia e Botucatu reconhecidas em afloramentos.

Foram analisadas aproximadamente 68 seções delgadas de amostras de calha, referentes a 28 poços de captação de água (litotecas do DAEE e CPRM), além de 48 seções delgadas de testemunhos e amostras de calha relativos a cinco poços de prospecção de petróleo. As análises foram realizadas em microscópio petrográfico Carl-Zeiss Axioplan 2 do Laboratório de Petrografia Sedimentar do IGcUSP.

\section{Microscopia com catodoluminescência}

O uso da catodoluminescência, técnica que consiste na investigação da radiação (luminescência) produzida por determinado material submetido à emissão de feixe de elétrons energizados, tem sido amplamente empregada na petrografia, especialmente em rochas sedimentares, no diagnóstico de crescimentos secundários diagenéticos de quartzo e feldspato, no reconhecimento de zoneamentos complexos de cimentos carbonáticos e na delineação das sucessivas fases de precipitação mineral (Marschall 1988).

O comprimento de onda e intensidade da luminescência gerada pela incidência de elétrons energizados reflete as características do mineral e distribuição de impurezas. Para o quartzo, a luminescência é relativamente fraca se comparada com a de feldspato e carbonatos. Geralmente, o quartzo autigênico (cimento) apresenta catodoluminescência relativamente mais fraca do que o quartzo detrítico (grão). 
Estudos pioneiros de uso de catodoluminescência (CL) para estudos diagenéticos de arenitos, desenvolvidos por Sippel (1965), demonstraram que o quartzo autigênico, na forma de cimento intersticial ou sobrecrescimento, apresenta $\mathrm{CL}$ ausente ou francamente mais fraca que a do quartzo detrítico, com ocorrência de nítido contraste entre os dois tipos, mesmo que ocorra continuidade óptica entre as duas fases minerais.

O contraste de CL entre quartzo autigênico e detrítico é interpretado como devido à diferença de temperatura de formação, que é menor no quartzo secundário. O uso de catodoluminescência para estudos de quartzo exige correntes de energização de elétrons com voltagens relativamente maiores do que as empregadas para obter luminescência de carbonatos e feldspatos, quando geralmente se empregam correntes entre 5 e 7 kVolts. Para o quartzo, é necessário a energização dos elétrons sob correntes superiores a 12 kVolts e muitas vezes determinadas feições somente são observadas com uso de correntes com voltagens superiores a 20 kvolts, sendo típicos os valores por volta de 30 kVolts (Sippel 1965, Zinkernagel 1978).

No estudo das amostras de arenitos das formações Pirambóia e Botucatu, foi empregado o luminoscópio ELM - 3 R do Laboratório de Ótica do IGc-USP, com corrente de 1 a 2 mA e voltagem máxima de 15 kVolts.

\section{Análise de imagens digitais}

Utilizou-se análise de imagens digitais para quantificar a porosidade em seção delgada de material de calha do poço de Barretos, o qual apresentou amostragem mais representativa das formações Pirambóia e Botucatu, comparativamente aos outros poços. Os procedimentos básicos adotados para este tipo de análise foram:

1. aquisição de imagens digitais coloridas, a partir de câmera compacta digital (CCD) acoplada a microscópio petrográfico, as quais são armazenadas no formato TIF;

2. obtenção da imagem binária a partir do processo de discriminação do matiz (hue) dos poros; 
3. tratamento da imagem binária através de sucessivas etapas de correção e edição, de modo que a imagem discriminada coincida fiel e estritamente com os poros da amostra;

4. detecção do percentual de pixels da imagem discriminada em relação aos da imagem total, o que corresponde à porcentagem em área de poros da seção.

Para cada amostra, captaram-se e gravaram-se todas as imagens necessárias (fase 1) para então proceder à análise de porosidade (fases 2 a 4) em cada imagem previamente gravada.

Os procedimentos descritos foram executados com uso de microscópio petrográfico Carl-Zeiss Axioplan 2 do Laboratório de Petrografia Sedimentar do IGcUSP, acoplado a câmera Sony 3CCD, tendo sido a imagem captada e trabalhada através do software Leica Qwin 550. As imagens digitais foram obtidas com um aumento de 100x (objetiva e ocular de 10x de aumento) e resolução de 512x512 pixels, que neste caso representa um Campo de Visão Microscópica (CVM) de 0,28 $\mathrm{mm}^{2}$ de área. No caso de amostras de granulometria média na fração areia média ou grossa, utilizou-se aumento de 50x (objetiva de 5x e ocular de 10x de aumento), o que significa um CVM com área de $1,14 \mathrm{~mm}^{2}$.

Para uma análise representativa de cada amostra, foram obtidos o mínimo de 10 e o máximo de 30 CVM's por seção de fragmento de calha (Ehrlich et al. 1991a), de forma que a porcentagem mínima de cobertura da área da amostra fosse de $1 \%$ (Mowers \& Budd 1996).

A rotina utilizada para quantificação da porosidade foi adaptada de uma rotina contida no banco de dados do software Qwin. A introdução progressiva de etapas de tratamento de imagem e de binários na rotina original resultou na geração de oito diferentes versões, sendo que a versão utilizada neste trabalho é denominada "porosidade-library-color-v-3.1". Nas etapas de detecção de imagem, optou-se pelo uso do histograma de matiz (hue), o qual se mostrou suficientemente preciso na diferenciação entre pixels referentes a poros (tons de azul na imagem) e pixels associados a arcabouço e cimentos (não poro), conforme proposta de Crabtree et al. (1984). 


\subsubsection{Análise no sistema MEV-EDS}

O sistema MEV-EDS é constituído por Microscópio Eletrônico de Varredura (MEV) e equipamento acoplado de Espectrometria de Energia Dispersiva de raios $\mathrm{X}$ (sigla EDS do termo em inglês). O processo de obtenção de imagens no MEV faz-se através da detecção de elétrons emitidos pela superfície da amostra submetida a um feixe eletrônico. Este equipamento possui detectores para dois tipos diferentes de emissões de elétrons. O detector de elétrons secundários, ou SE (secondary electrons), produz imagens representativas da topografia da amostra, enquanto o detector de elétrons retroespalhados, ou BSD (backscattered detector), gera imagens em que as tonalidades de cinza correspondem a variações do peso atômico médio dos constituintes elementares. O equipamento de EDS faz a detecção dos raios $X$ emitidos pela amostra e permite assim realizar análises químicas elementares semiquantitativas pontuais.

Submeteram-se a este tipo de análise amostras brutas de fragmentos subcentimétricos de arenito (amostras em fratura viva), assim como seções delgadas. Os fragmentos foram recobertos com película de ouro e as seções delgadas com película de carbono. Imagens de detectores de elétrons secundários foram obtidas preferencialmente em amostras brutas, ao passo que as imagens de seções delgadas obtiveram-se preferencialmente através de detectores de elétrons retroespalhados.

Cerca de 24 amostras de subsuperfície e quatro de afloramento foram analisadas no sistema MEV-EDS. Com este equipamento, foi possível a observação detalhada das fases minerais, em especial os cimentos de argilominerais, do espaço poroso e das relações intergranulares entre arcabouço e cimentos, além da obtenção de análises químicas semiquantitativas dos cimentos em seções delgadas. O equipamento utilizado foi um LEO 440I do Laboratório de Microscopia Eletrônica do IGc-USP.

\subsection{Análise dos dados de subsuperfície}

Um volumoso acervo de dados de poços de captação de água subterrânea do DAEE e da CPRM, compreendendo relatórios e perfis geofísicos de 30 poços, foi revisado e parcialmente xerocopiado. Os poços perfurados pela CPRM contam com perfis elétricos (potencial espontâneo, resistividade normal curta e normal longa), radioativos (gama natural e muito raramente gama induzido), e, em alguns casos, 
acústicos (sônico). A análise destes perfis auxiliou no reconhecimento dos limites estratigráficos entre as formações Pirambóia e Botucatu em subsuperfície, em complemento à revisão das amostras de calha. Paralelamente foi montado um banco de dados de informações de poços, relativas à localização, estratigrafia e características petrográficas.

Os dados estratigráficos (revisão dos poços de água) e sedimentológicos (petrografia sedimentar), organizados em banco de dados, foram lançados sobre mapa base geológico, utilizando-se o software ArcView 9.1.

A base cartográfica utilizada neste trabalho resultou da compilação das folhas SE-22 (Goiânia), SF-22 (Paranapanema) e SG-22 (Curitiba), da Carta Internacional do Mundo ao Milionésimo, obtidas via internet por download a partir do sítio do IBGE (Instituto Brasileiro de Geografia e Estatística). A base geológica adotada é o mapa geológico do Estado de São Paulo, escala 1:750.000 (Perrotta et al. 2005). 


\section{CONTEXTO GEOLÓGICO}

O conjunto sedimentar essencialmente psamítico subjacente e intercalado às rochas efusivas da Bacia do Paraná chama a atenção dos pesquisadores desde a última década do século XIX. Os trabalhos publicados pela Comissão Geográfica e Geológica de São Paulo foram pioneiros na descrição dos arenitos infrabasálticos aflorantes ao longo da escarpa da serra de Botucatu, localidade que Gonzaga de Campos (1889 apud Soares 1975) utilizou para criar a designação "Arenito Botucatu".

O reconhecimento de distintas litologias dentro de um mesmo intervalo estratigráfico sob os basaltos, como arenitos com estratificações cruzadas de grande porte, arenitos argilosos estratificados e lutitos (siltitos e argilitos), resultaram na denominação destes depósitos, respectivamente, como "Arenito Botucatu", "Arenito Pirambóia" e "Arenito Santana" (Pacheco 1927 e Florence \& Pacheco 1929 apud Washburne 1930). A partir destes estudos pioneiros, seguiu-se um longo e fecundo período de estudos e discussões, que se estende até os dias de hoje, acerca da estratigrafia, da interpretação dos processos deposicionais e da idade destes depósitos.

\subsection{Estratigrafia}

Anteriormente à década de 1970, as sucessões psamíticas mesozóicas da Bacia do Paraná eram consideradas uma única unidade litoestratigráfica, denominada Arenito ou Formação Botucatu lato sensu, a qual, em conjunto com a unidade vulcânica, compunha a Série ou Grupo São Bento. O reconhecimento de depósitos arenáceos e lutáceos com características litológicas e genéticas distintas levou à designação, ainda que informal, de Arenito Pirambóia, ao domínio inferior da unidade Botucatu lato sensu. Esta nova unidade foi associada inicialmente à deposição subaquosa de caráter lacustre e fluvial (Washburne 1930, Almeida \& Barbosa 1953, Almeida 1954). O termo Arenito Botucatu sensu stricto (Washburne 1930) passou então a ser utilizado para designar o conjunto sedimentar, em posição estratigráfica superior, consensualmente atribuído a origem eólica.

Os trabalhos de Soares $(1973,1975)$ marcam a formalização do Arenito Pirambóia no status de formação, individualizada da Formação Botucatu segundo critérios faciológicos e geomorfológicos específicos da faixa aflorante no centro- 
leste paulista. Em termos faciológicos, Soares (1973, 1975) manteve a linha interpretativa, vigente à época, de sedimentação fluvial (meandrante), para a Formação Pirambóia, e eólica, para a Formação Botucatu.

A presença de sedimentos finos no Arenito Pirambóia tradicionalmente foi usada como argumento para interpretar o predomínio de deposição subaquosa nesta unidade. Desta forma, pode-se reconhecer uma precoce distinção faciológica entre as unidades Pirambóia e Botucatu, sendo que as divergências de interpretação residiram no tipo de sistema deposicional dessa unidade, se flúviolacustre (Almeida \& Barbosa 1953), fluvial entrelaçado (Bosio 1973) ou fluvial meandrante (Soares 1975).

A partir da década de 1990, Lavina (1991) e Caetano-Chang et al. (1991) passam a questionar a relação entre presença de finos e origem exclusiva por transporte e deposição subaquosos para a Formação Pirambóia. Para CaetanoChang \& Wu (1992a,b; 1993), a sedimentação desta unidade pode ser caracterizada por predomínio de processos eólicos, e subordinadamente flúvioaluviais, no contexto faciológico de depósitos de dunas, interdunas e lençóis de areia (sandsheets). Os finos seriam em parte de origem diagenética, inclusive precoce, e em parte relacionados à presença de água em fácies interdunas.

\subsection{Sistema deposicional eólico úmido versus eólico seco}

Caetano-Chang \& Wu (1993) diferenciam os sistemas eólicos Pirambóia e Botucatu através da maior complexidade faciológica do primeiro, em contraposição à simplicidade do segundo. Para estes autores, a Formação Pirambóia seria caracterizada pela combinação de sistemas de extra-erg e erg, com umidade decrescente da base para o topo da unidade, ao passo que a Formação Botucatu representaria um sistema de erg seco. Uma superfície de deflação regional marcaria o contato discordante entre as duas formações.

Dentro da concepção de sistema deposicional de erg e extra-erg para a Formação Pirambóia, Caetano-Chang \& Wu (1992a) e Caetano-Chang (1997) descrevem quatro associações de fácies principais: dunas, interdunas, lençóis de areia e canais fluviais efêmeros (wadi). A associação de dunas eólicas compreeende depósitos de frentes (foresets) e de "caudas de dunas". Os primeiros apresentam estratos cruzados de geometria acanalada, com alto ângulo de mergulho em séries de espessura métrica, onde o processo predominante seria a 
queda de grãos (grainfall); nos depósitos de caudas de dunas, os estratos cruzados são tipicamente de baixo ângulo de mergulho e as estruturas sedimentares mais comuns são gradação inversa, relacionada a processos de avalanche (grainflow), e ondulações eólicas. Texturalmente, os depósitos de dunas são caracterizados por arenitos muito finos a finos, às vezes siltosos, com intercalações de lâminas de arenito médio a grosso, que apresenta boa seleção, alta maturidade e, localmente, bimodalidade granulométrica.

Segundo os autores supracitados, a associação de interdunas eólicas é formada por fácies de geometria tabular, aspecto geral maciço e discreta laminação plano-paralela e compreende interdunas secas, interdunas úmidas (dump), interdunas aquosas (wet) e interdunas de overbank. Na fácies de interdunas secas, encontram-se laminações sub-horizontais formadas por migração de ondulações eólicas, além de feições de escavação e estruturas deformacionais. À semelhança das interdunas secas, nas interdunas úmidas os autores admitem a coexistência de processos de migração de ondulações eólicas (tração) e queda de grãos, responsáveis pela bimodalidade granulométrica dos estratos, com a diferença de que no substrato umedecido são maiores as chances de preservação destas estruturas. A maior presença de água nas interdunas aquosas resulta na deposição de lâminas argilo-siltosas e formação de laminações de ôndulas cavalgantes subaquosas. Além destas feições, os autores relatam presença de estruturas de dessecação na fácies de overbank. Em termos texturais, nas interdunas predominam arenitos finos e muito finos siltosos, com matriz de argilas infiltradas, seleção regular e maturidade variável, clastos de lama e intercalações delgadas de argilitos, sendo comuns bimodalidade granulométrica e alterações localizadas por bioturbação.

As fácies de lençóis de areia, na concepção de Caetano-Chang (1997), representam depósitos delgados de arenitos finos e muito finos, com ou sem silte, marcados por laminação sub-horizontal sub-centimética, com ondulações eólicas de cavalgamento subcrítico, nos quais se encontram intercaladas delgadas lentes de arenito médio a grosso, às vezes com gradação inversa. Os depósitos de wadi constituem registro de feições efêmeras e de pequeno porte (submétrico), caracterizados por estruturas de corte, com geometria acanalada e base erosiva irregular, preenchidas por arenitos finos de aspecto maciço ou estratificação cruzada incipiente, contendo na base intraclastos de arenito e ventifactos. 
Embora considerem os depósitos fluviais subordinados no âmbito do sistema eólico Pirambóia, Caetano-Chang \& Wu (1993) relatam a presença de arenitos médio-grossos, atribuídos a sheetfloods, e arenitos conglomeráticos, atribuídos a leques aluviais, associados a arenitos supostos como de dunas eólicas, próximo ao contato superior com a Formação Botucatu. Para Caetano-Chang (1997), estes depósitos rudáceos são designados Arenito Itirapina e é aventada a hipótese de contemporaneidade entre as fácies eólicas e as do sistema de canais fluviais entrelaçados. Na acepção de Soares (1975), estes depósitos são posicionados na base da Formação Botucatu e corresponderiam a eventos torrenciais do início da sedimentação desta unidade.

A predominância de depósitos de arenitos finos dispostos em sets de estratificação cruzada de grande porte, típicos da Formação Botucatu, considerados de fácies de frentes de dunas eólicas, denotam o caráter monótono desta unidade, em termos faciológicos, como já ressaltado, entre outros, nos trabalhos de Soares (1973, 1975) e Caetano-Chang (1997). A última autora descreve os arenitos como finos e médios, com frações subsidiárias de arenito muito fino e grosso, quartzosos e com marcante bimodalidade granulométrica dos estratos imposta por processos de avalanche (grainflow). O teor de finos (silte e argila), segundo ela, é inferior a $5 \%$, e os grãos apresentam bom arredondamento e superfície fosca.

Estudos centrados na faixa aflorante da bacia, nos estados de São Paulo e Paraná, subsidiaram o desenvolvimento de projeto de pesquisa voltado à elaboração de modelo genético integrado da sucessão Pirambóia-Botucatu, com os principais resultados sumarizados em Giannini et al. (1999, 2004), Sawakuchi (2000), Oliveira (2001), Giannini (2001), Donatti et al. (2001) e Donatti (2002). Neste estudo, foi possível individualizar cinco associações de fácies, sendo quatro delas representantes do sistema deposicional eólico úmido (costeiro) Pirambóia, e uma correspondente ao sistema eólico seco Botucatu, de acordo com nomenclatura de sistemas deposicionais eólicos de Kocurek \& Havholm (1993).

O sistema eólico úmido Pirambóia, segundo proposta de Giannini (2001), é caracterizado, da base para o topo, por fácies de lençóis de areia em planície de marés, fácies de campo de dunas costeiro inferior, com planícies interdunas alagadas, fácies de campo de dunas costeiro superior, com planícies interdunas raramente inundadas, e fácies de planície aluvial, com desenvolvimento de rios entrelaçados e dunas. A umidade neste sistema deu-se em decorrência do nível freático elevado, provavelmente em virtude da proximidade à costa do sistema 
marinho coetâneo (Grupo Passa Dois). O sistema eólico Botucatu é representado por fácies de campo de dunas seco.

A associação de fácies de lençóis de areia ocorre em contato interdigitado com os sedimentos do Grupo Passa Dois (Formação Teresina/Corumbataí), o que caracteriza passagem transicional entre os depósitos marinhos e as areias do sistema eólico em implantação. Esta associação é formada por arenitos finos com estratificação cruzada de ângulo de mergulho baixo $\left(<10^{\circ}\right)$, arenitos maciços e brecha de matriz arenosa com clastos de silexito, os quais se intercalam com siltitos e carbonatos típicos do topo do Grupo Passa Dois. O contato é marcado por feições de perturbações penecontemporâneas, como estruturas de sobrecarga, gretas de dessecação e brechas intraclásticas recorrentes.

Segundo o modelo proposto por Giannini (2001), a associação de campo de dunas costeiro, com interdunas alagadas, ocorre na porção inferior da Formação Pirambóia, sobreposta às fácies de lençóis de areia, e é caracterizada por sistema eólico bem desenvolvido, com depósitos eólicos de dunas e interdunas, além de depósitos suaquosos de canais efêmeros (wadi). Esta associação é representada por fácies de arenitos finos a médios com estratificações cruzadas acanaladas de ângulo de mergulho alto $\left(>10^{\circ}\right)$, dispostos em sets de espessura decimétrica a métrica, interpretadas como frentes de dunas barcanas e/ou barcanóides. Ocorrem ainda arenitos muito finos, sílticos, com estratificação cruzada de ângulo de mergulho baixo e arenitos finos com laminação plano-paralela, os quais apresentam intercalações de lâminas silto-argilosas onduladas (laminação heterolítica), feições de fluidificação, climbings subcríticas e marcas onduladas simétricas, revelando contexto interdunas úmido a subaquoso (Giannini 2001).

A metade superior da Formação Pirambóia, segundo Giannini (2001), é caracterizada por um campo de dunas com diminuição sensível da presença de água nos domínios interdunas, o que foi relacionado pelo autor ao distanciamento progressivo da linha de costa do sistema marinho Passa Dois. A variedade faciológica desta associação é menor, denotada pela presença de arenitos com estratificações cruzadas de ângulo de mergulho alto (fácies de dunas) e arenitos finos a médios com cruzadas de ângulo baixo ou estratificação sub-horizontal (fácies de interdunas úmidas), com níveis subordinados de pelitos e feições deformacionais (convoluções). 
As fácies de planície aluvial são caracterizadas por depósitos rudáceos, que integram o desfecho do sistema deposicional eólico úmido Pirambóia. Trata-se de arenitos conglomeráticos com estratificações cruzadas acanaladas de pequeno e médio porte, freqüentemente com lâminas com gradação normal. Para Giannini (2001), estas fácies representariam o desenvolvimento de rios entrelaçados, distais a sistema de leques aluviais, durante fase de acentuada atividade tectônica na bacia.

O sistema eólico Botucatu é constituído, segundo Giannini (2001), por fácies de arenitos finos a muito finos com laminação milimétrica, dispostos em séries de estratificações cruzadas de geometria lenticular, com espessura média de $3 \mathrm{~m}$ e extensão decamétrica. A estratificação, marcada por lentes de fluxo granular relativamente delgadas (menos de $3 \mathrm{~cm}$ ), seria representativa do avanço de dunas e draas em campo de dunas seco. Estratificação deformada e laminações cruzadas cavalgantes subcríticas são feições relativamente freqüentes. De forma subordinada, mais tipicamente próximo ao contato basal da unidade, ocorrem arenitos com estratificação cruzada de ângulo baixo, que poderiam representar planícies ou depressões interdunas da fase de instalação do sistema deposicional eólico.

Destaca-se, enfim, certa convergência recente das linhas de interpretação que associam a sedimentação da Formação Pirambóia a um sistema eólico úmido (Assine et al. 2004), distinto do sistema eólico seco da Formação Botucatu (Scherer 2000). Divergências ainda persistem, como a interpretação de contemporaneidade (Matos 1995, Giannini 2001, Giannini et al. 2004) ou não (Soares 1975, CaetanoChang 1997) entre o início do sistema eólico Pirambóia e o final do sistema marinho Passa Dois.

\subsection{Proveniência e idade}

A reconstituição da paleogeografia a partir de estudo de rumos de paleocorrentes eólicas na Formação Botucatu lato sensu, obtidas em afloramentos do centro-sul brasileiro, constitui o escopo dos clássicos artigos de Bigarella \& Salamuni (1961) e Bigarella (1973). Nestes trabalhos, os autores reconheceram dois domínios, com orientações opostas, de paleoventos: um setentrional (MG, SP e norte do PR), com rumos para SW, e outro meridional (sul do PR, SC e RS), para $\mathrm{NE}$, sendo que o centro do Paraná seria zona de convergência de paleofluxo. Para 
os autores, o paleodeserto Botucatu (lato sensu) estaria posicionado em baixas latitudes durante o Juro-Cretáceo e a distribuição de rumos de paleoventos refletiria o padrão de circulação de alísios de retorno, provenientes de $\mathrm{N}$ e $\mathrm{NE}$ (domínio setentrional), além de ventos vindos de W (domínio meridional), derivados de células de alta pressão localizadas sobre o paleo-oceano Pacífico.

A individualização do conjunto psamítico Botucatu lato sensu em unidades estratigráficas com possíveis idades e contextos deposicionais distintos criou a necessidade de revisar o quadro paleogeográfico delineado por Bigarella \& Salamuni (1961). Soares (1973) atribuiu à Formação Pirambóia, no leste paulista, paleocorrentes fluviais para W e SW. Nesta mesma região, Assine (1993) individualizou paleocorrentes eólicas e fluviais na unidade Pirambóia, com rumos de paleofluxo voltados, respectivamente, para sul (SE e SW) e oeste (WNW). Também no centro-leste paulista, Caetano-Chang (1997) inferiu dois rumos preferenciais de paleoventos desta formação, um na porção inferior da unidade, para SE, e outro na poção superior, para SW. Além das paleocorrentes eólicas, esta autora destacou paleofluxo fluvial no topo da formação (Arenito Itirapina), com rumo persistente WNW.

Mais recentemente, Giannini et al. (2004) coletaram quase um milhar de medidas de azimutes de mergulho de estratificações cruzadas da Formação Pirambóia, ao longo da faixa aflorante nos estados de São Paulo e Paraná, utilizando critérios de fatiamento estratigráfico, posição geográfica e fácies deposicionais. Estes autores puderam inferir rumos de paleoventos e paleocorrentes fluviais utilizando testes de uniformidade (testes de hipóteses estatísticas). Os resultados reforçaram a existência de zona de convergência de paleoventos, no norte do Paraná, durante todo o desenvolvimento do sistema deposicional eólico Pirambóia, com ligeira migração desta zona de convergência para sul no topo da unidade, quando teria atingido o centro-norte deste estado. Giannini et al. (2004) discutem a possibilidade desta zona de convergência refletir um padrão de circulação atmosférica global, como suposto por Bigarella (1973), ou da existência de paleorrelevo de direção NW, que tivesse promovido o bloqueio local dos paleoventos, sem descartar a possibilidade de coexistência dos dois fatores. Os rumos de paleocorrentes subaquosas, reconhecidos neste trabalho, apresentam grande variabilidade e podem estar associadas tanto a paleofluxo fluvial entrelaçado quanto de correntes de maré. À primeira possibilidade poderia inferir-se paleodeclividade na bacia para SW no norte do Paraná (todo intervalo 
sedimentar Pirambóia) e sudoeste de São Paulo (só fatia inferior), balizada pela ocorrência de paleoalto estrutural nesta região.

As idades das formações Pirambóia e Botucatu não são, ainda hoje, bem definidas, principalmente pela escassez de conteúdo fossilífero. Soares (1973, 1975) posicionou a sedimentação destas unidades no intervalo entre o Triássico Médio e o limite Jurássico-Cretáceo. Baseou-se para isso nas relações de contato da base da Formação Pirambóia (por ele considerada discordante sobre o Grupo Passa Dois) e do topo da Formação Botucatu (contemporâneo ao início dos derrames de lava) e na correlação estratigráfica da Formação Pirambóia com a Formação Rosário do Sul, aflorante no Rio Grande do Sul, de idade Triássica Superior. Outros autores, entre eles Riccomini et al. (1984), Lavina (1991) e Matos (1995), consideram contato discordante entre as formações Pirambóia e Botucatu e contemporaneidade entre o início da sedimentação Pirambóia e a Formação Corumbataí / Rio do Rasto. Deste modo, posicionam a sedimentação Pirambóia no Permo-Triássico. Há ainda uma terceira linha interpretativa de que os limites estratigráficos superior e inferior da Formação Pirambóia seriam discordantes, respectivamente, com a Formação Serra Geral e o Grupo Passa Dois (Rohn 1994, Caetano-Chang 1997), e que o início da sedimentação desta unidade teria se dado no Triássico Médio.

Com base na interdigitação dos arenitos da Formação Botucatu com os vulcanitos da Formação Serra Geral, alguns autores supõem que a sedimentação da unidade tenha ocorrido entre o final do Jurássico e o início do Cretáceo (Schneider et al. 1974, Caetano-Chang \& Wu 1992a, Caetano-Chang 1997). Riccomini (1995), no entanto, posiciona todo o intervalo de tempo de deposição da Formação Botucatu no Cretáceo Inferior, contemporâneo ao início do vulcanismo Serra Geral.

A coluna estratigráfica do paleozóico-mesozóico da Bacia do Paraná, adotada neste trabalho, encontra-se na Figura 3.1. 


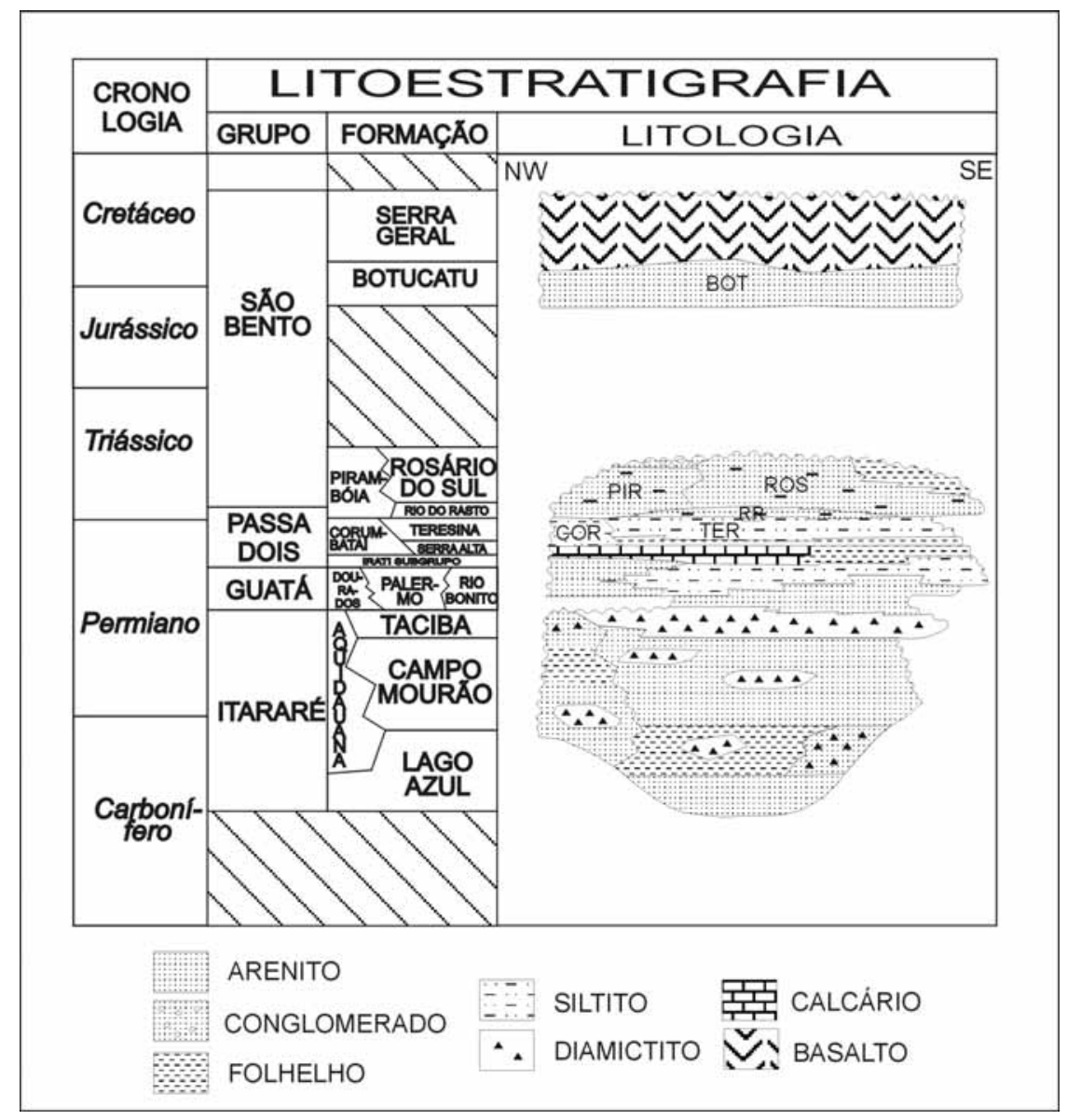

Figura 3.1 - Coluna litoestratigráfica da Bacia do Paraná. Baseada em Milani et al. (1994) e Matos (1995).

\subsection{Aspectos petrográficos}

Estudos voltados à caracterização mineralógica e granulométrica das formações Pirambóia e Botucatu evidenciam diferenças marcantes na textura e mineralogia entre os litotipos destas unidades.

Em estudos petrográficos do "Arenito de Anhembi" (atualmente admitido consensualmente como Formação Pirambóia), Leinz (1938) já havia reparado em feições texturais "indicativas de deposição eólica", como granulometria modal na fração areia muito fina $(0,1 \mathrm{~mm})$, baixo conteúdo de argila, ótima seleção e bom arredondamento dos grãos na fração modal.

Análises mineralógicas comparativas da assembléia de minerais pesados das formações Furnas, Rio Bonito e Botucatu, realizadas por Suguio et al. (1974), demonstraram a eficiência da investigação das feições texturais dos grãos na diferenciação estratigráfica das unidades. Segundo estes autores, a Formação Botucatu, mais jovem, apresenta alto índice de arredondamento e esfericidade dos 
minerais pesados ultraestáveis (zircão, turmalina, rutilo) em contraposição às feições angulosas da estaurolita (mineral metaestável), como bordas serrilhadas, interpretadas como de alteração química. Para estes autores, as primeiras feições seriam sugestivas de canibalismo sedimentar para a unidade, e as últimas, de corrosão diagenética (dissolução intraestratal).

O predomínio de minerais ultraestáveis bem arredondados como característica típica das assembléias de minerais pesados das formações Pirambóia e Botucutu foi reconhecido também por Wu \& Caetano-Chang (1992a) e por eles apontado como indicativo de transporte prolongado. Estes autores definiram duas províncias mineralógicas no centro-leste paulista, uma característica da Formação Pirambóia, composta por alta a moderada porcentagem de minerais metaestáveis (estaurolita, granada e epídoto), e outra dominante na Formação Botucatu, que apresenta alta porcentagem de minerais opacos (magnetita e ilmenita). A assembléia de minerais pesados revelou importante contribuição de rochas metamórficas na porção central e sudoeste da faixa de afloramentos em São Paulo e derivação a partir de sedimentos preexistentes na porção nordeste do estado, próxima à borda da bacia. Para estes autores, a presença de estaurolita nas assembléias minerais reforçaria a condição de clima árido e ambiente desértico destas unidades, em função da alta resistência à abrasão mecânica e estabilidade química moderada deste mineral. O conteúdo significativo de opacos na assembléia da Formação Botucatu indicaria, ainda, contribuição do magmatismo cretáceo contemporâneo à deposição desta unidade.

Wu \& Caetano-Chang (1992c) classificaram os sedimentos da Formação Pirambóia como subarcóseos (segundo classificação petrográfica de Folk 1968), considerados maturos, em termos mineralógicos, e submaturos a maturos, em termos texturais. A Formação Botucatu seria composta principalmente por quartzoarenitos com alta maturidade textural e mineralógica (maturos a supermaturos). A Formação Pirambóia apresenta tipicamente maior conteúdo de feldspatos (3\% a $10 \%$ ) e de matriz secundária (argilas infiltradas) do que a Formação Botucatu, sendo comum em ambas as unidades cimentação por óxido-hidróxido de ferro e por argilominerais.

Os resultados da análise granulométrica e da petrografia de arenitos, reunidos em Giannini (2001), revelam tendência nítida para engrossamento dos arenitos, da base para o topo do sistema eólico Pirambóia, e tendência sutil de afinamento, da base para o topo do sistema eólico Botucatu. O sistema eólico 
Pirambóia inferior é caracterizado por arenitos finos e muito finos (nas fácies de interdunas) e arenitos finos a médios (nas fácies de dunas), com conteúdo variável, porém relativamente alto $(<20 \%)$, de pelitos, teor que tende a diminuir (menor relação fino/grosso) nas fácies de dunas do domínio superior deste sistema. A fácies rudácea, do topo do sistema eólico úmido Pirambóia, apresenta granulometria modal na fração areia média ou grossa, presença significativa de grânulos e seixos e baixa razão fino/grosso (areia mais cascalho / silte mais argila). Com relação ao sistema eólico seco Botucatu, os arenitos apresentam estreita faixa de variação da granulometria, dentro da fração areia fina, e baixa relação fino/grosso.

Em termos mineralógicos e diagenéticos, Giannini (2001) diferencia os arenitos das fácies eólicas dos sistemas Pirambóia e Botucatu através do maior conteúdo de feldspatos ( $5 \%$ a $15 \%$ ), maior razão de tamanho entre quartzo e feldspato, menor volume de cimento (<10\%) e maior porosidade $(12 \%$ a $35 \%)$ do primeiro em relação ao segundo. Os arenitos do sistema Pirambóia são quartzoarenitos e arenitos feldspáticos (na classificação de Dott 1964), com arcabouço relativamente aberto, feições indicativas de moderada compactação química (contatos entre grãos do tipo planar e pontual) e presença de feições de dissolução diagenética (porosidade intragranular do tipo alveolar em grãos de feldspato e estaurolita com bordas corroídas). Os arenitos do sistema Botucatu, segundo este autor, são quartzo-arenitos com maior percentual de cimentação (até 15\%), porosidade variável ( 0 a 25\%) e apresentam feições menos evidentes de dissolução diagenética (feldspato bem preservado), muitas vezes só detectadas sob MEV.

França et al. (2003) advertem que o conteúdo escasso de feldspato da Formação Botucatu em superfície, 3\% em média, deve-se à quase completa lixiviação deste mineral devido à percolação intensa de águas meteóricas, da borda para o centro da bacia. Em subsuperfície, o conteúdo de feldspato aumenta para, em média, $15 \%$, desde zona de confinamento relativamente rasa (pelo menos 30 $\mathrm{km}$ de distância da borda aflorante) até zona de confinamento profundo. Reconhecem quatro tipos principais de cimento: cutículas precoces de hematita e illita, que ocorrem em praticamente toda a bacia, calcita/dolomita intersticial, calcedônia/opala intersticial e sobrecrescimento de quartzo e feldspato. Este último tipo foi identificado exclusivamente nas porções de confinamento profundo, ao passo que o cimento de calcedônia/opala é típico das porções mais próximas à borda aflorante. A calcita, por sua vez, caracteriza cimento de ampla, porém 
heterogênea, distribuição, desde cerca de mais de $10 \%$ em volume de rocha total no centro da bacia até praticamente desaparecer $(<0,5 \%)$ em profundidades menores que $250 \mathrm{~m}$. A porosidade média dos arenitos medida em seção delgada (amostras de testemunhos) é de cerca de 16\%, embora os autores estimem valores mais altos, de até $30 \%$, com base em perfis sônicos de poços. Nesse trabalho, não foi reconhecida nenhuma variação significativa de porosidade na Formação Botucatu que pudesse estar ligada à profundidade ou posição em relação ao interior e borda da bacia, apesar das mudanças no tipo de cimento. No geral, a porosidade secundária, gerada pela dissolução de grãos de feldspato e de cimento carbonático, teria sido gerada pelo influxo de águas meteóricas e possivelmente ampliou a porosidade primária, já originalmente alta.

O quadro evolutivo da diagênese em amostras de superfície das formações Pirambóia e Botucatu, delineados por Giannini (2001) e Donatti (2002), aponta para uma maior complexidade no caso da primeira unidade, devido possivelmente à dissolução pós-deposicional preferencial ou mais prolongada. Donatti (2002) reconhece a seguinte seqüência de eventos diagenéticos no sistema eólico Pirambóia: formação de película ferruginosa (de textura sacaroidal) envoltória aos grãos, envelope argilo-ferruginoso (esmectita) envoltório e sobrecrescimento de quartzo, na fase eodiagenética; compactação mecânica e química (incipiente) e cimentação de sílica microcristalina instersticial, em fase mesodiagenética; e geração de porosidade secundária (alveolar) e cimento de argilominerais (caulinita), durante a telodiagênese. A seqüência de eventos diagenéticos do sistema eólico Botucatu admitida por mesmo autor seria: formação de película argilo-ferruginosa envoltória, sobrecrescimento sintaxial de quartzo e franja envoltória de argilominerais (esmectita), na eodiagênese; compactação mecânica e química (incipiente), durante a mesodiagênese; geração de porosidade secundária (dissolução de feldspatos e de provável cimento carbonático) e cimento argiloferruginoso intersticial, na telodiagênese. 


\section{MODELO GENÉTICO}

O modelo elaborado por Giannini (2001) e Donatti (2002), que associa a deposição da Formação Pirambóia ao desenvolvimento de sistema deposicional eólico úmido e a Formação Botucatu a sistema deposicional eólico seco, baseou-se em descrições de afloramentos destas unidades no Estado de São Paulo e norte do Paraná. Alguns afloramentos representativos destes sistemas deposicionais foram revisados neste estudo, com o intuito de ilustrar e fornecer o panorama síntese das fácies sedimentares encontradas, tendo em vista a premissa de testar, em subsuperfície, o modelo genético definido em superfície.

No modelo genético em questão, algumas premissas básicas são admitidas para as relações estratigráficas entre os sistemas deposicionais sucessivos. Referem-se à contemporaneidade entre o início da sedimentação do sistema eólico úmido Pirambóia e o sistema marinho Passa Dois, de um lado, e entre o desenvolvimento do sistema deposicional eólico seco Botucatu e os derrames Serra Geral, de outro. Desta forma, a superfície que separa o registro dos dois sistemas eólicos é uma discordância, cujo hiato de tempo não foi seguramente dimensionado até hoje.

Segue descrição e interpretação das principais fácies sedimentares que compõem os sistemas eólicos estudados. A nomenclatura de fácies segue aquela definida em Donatti (2002).

\subsection{Sistema eólico úmido Pirambóia}

O sistema eólico úmido Pirambóia constitui sucessão de associações de fácies com diversidade decrescente de litotipos da base para o topo, desenvolvido em contexto costeiro. Em termos gerais, este sistema pode ser subdividido informalmente em dois domínios: inferior, associado à instalação de campo de dunas costeiro, com marcante presença de água na sedimentação, e superior, associado ao desenvolvimento mais interiorizado do campo de dunas, sob linha de costa em recuo. Neste domínio superior, há ainda o registro de interação flúvioeólica no sistema deposicional.

As principais fácies sedimentares encontradas nas associações de campo de dunas costeiro são: 
Aca (arenitos com estratificações cruzadas de alto ângulo de mergulho): esta fácies é caracterizada por arenitos bimodais (areia fina e média) com estratificações cruzadas acanaladas de ângulo alto $\left(>10^{\circ}\right)$, compondo séries de espessura decimétrica a métrica e extensão decamétrica (Figura 4.1). A estratificação é marcada por segregação granular relacionada à alternância de depósitos de queda de grãos e fluxo granular, estes últimos constituindo estratos sub-centimétricos lenticulares, muitas vezes com gradação inversa. Esta fácies corresponde à migração de frentes de dunas eólicas, provavelmente barcanas e/ou barcanóides.
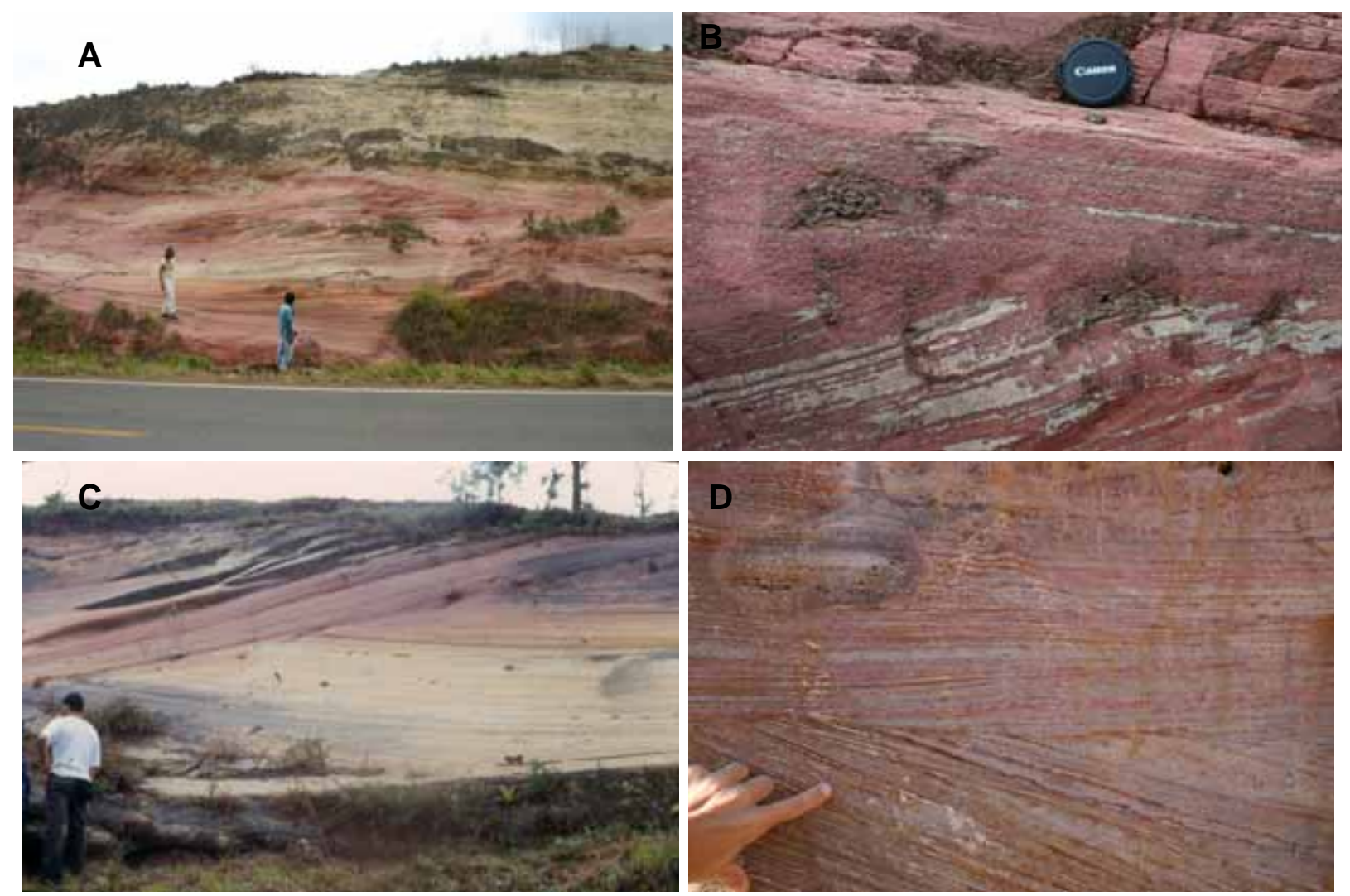

Figura 4.1 - Séries de estratificações cruzadas acanaladas da fácies Aca. Notar detalhe da estratificação e das superfícies de truncamento de $3^{a}$ ordem que delimitam as séries, nas fotografias B, C e D. A, B: afloramento da rodovia SP191, trecho entre Ipeúna e Charqueada.C: rodovia SP280, km 167. D: Areeiro CRS, rodovia SP225, km 74.

Acb (arenito com estratificação cruzada de baixo ângulo de mergulho): trata-se de arenitos finos, cuja granulometria varia desde areia muito fina síltica até areia média, com estratificação cruzada de ângulo de mergulho baixo $\left(<10^{\circ}\right)$, localmente de aspecto maciço, compondo geometria lenticular de extensão decamétrica, cuja base pode sobrepor superfícies residuais (lags de deflação), evidenciadas pela presença de seixos (Figura 4.2A). Nesta fácies, podem ser 
encontradas laminações cavalgantes subcríticas e bioturbação (Figura 4.2D). Quanto à interpretação, associa-se esta fácies aos domínios de interdunas úmidas do campo de dunas.
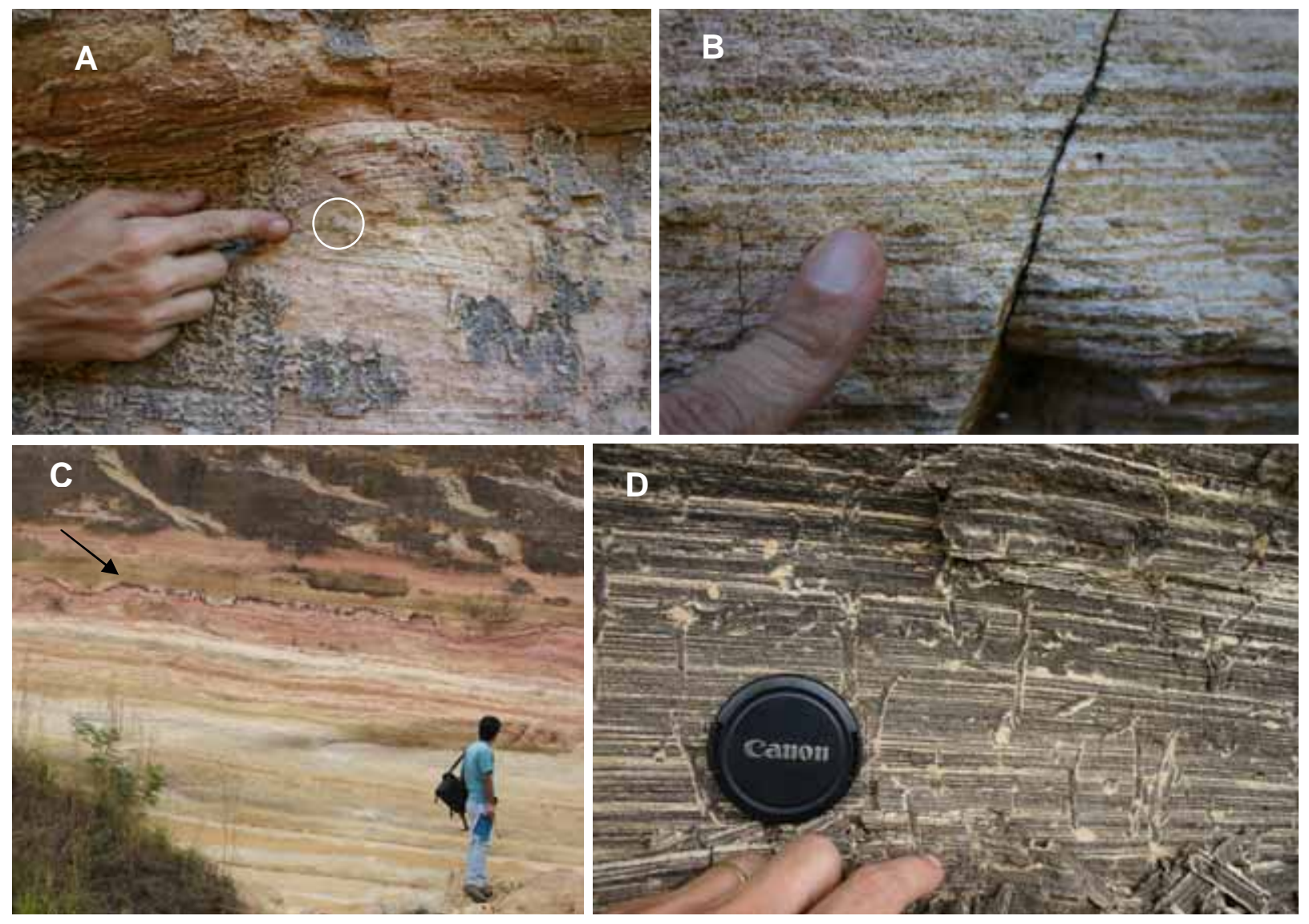

Figura 4.2 - Arenitos muito finos com estratificação de ângulo de mergulho baixo da fácies Acb (fotografia C), cuja granulação pode alcançar até areia média (fotografia $B$ ). Na fotografia A, a superfície residual com seixo (círculo) delimita a fácies Aca, abaixo, da fácies Acb, acima. Na fotografia $\mathrm{C}$, destaque para a superfície irregular (deformacional) que delimita duas camadas da fácies Acb sobrepostas (seta). Notar bioturbação ressaltada por cimento de betume na fotografia D. A, B: corte da Ferrovia FEPASA, sob viaduto da rodovia SP191, próximo à Ipeúna C: afloramento da SP191, trecho entre Ipeúna e Charqueada. D: Jazida Nhaíva, em Guareí.

Acbd (arenito com estratificação de baixo ângulo deformada): esta fácies é constituída de arenitos muito finos sílticos a arenitos médios, de espessura decimétrica, com estratificação deformada na forma de acamentos convolutos (Figura 4.3). Ocorre em horizontes confinados entre conjuntos de arenitos com estratificação horizontal ou cruzada de baixo ângulo (fácies Acb e Ash). Associa-se a domínios de interdunas úmidas cujos sedimentos foram fluidificados por agente externo, eventualmente sismos. 

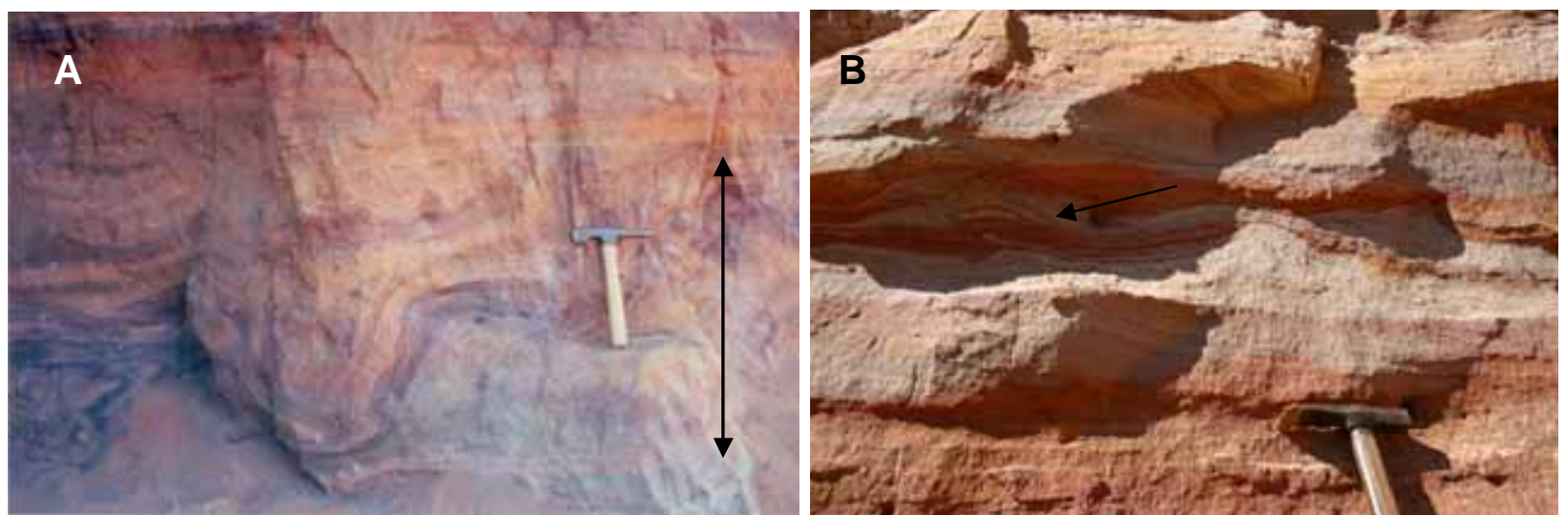

Figura 4.3 - Aspecto geral da fácies Acbd, onde o horizonte com convoluções (seta) está confinado entre camadas indeformadas das fácies Aca e Acb. A: Região de São Pedro. B: Areeiro Bragato, Descalvado.

Acbl (arenito com estratificação horizontal ou cruzada de baixo ângulo e intercalações de lutitos): esta fácies constitui-se de arenitos muito finos sílticos, onde intercalações argilo-siltosas de espessura milimétrica a subdecimétrica (até 6 $\mathrm{cm}$ ) caracterizam laminação horizontal heterolítica, localmente ondulada (Figura 4.4). As ondulações, com comprimento de onda típico de 6 a $7 \mathrm{~cm}$, são geralmente simétricas e formam às vezes laminações cruzadas de cavalgamento. Outras feições comuns são estruturas de sobrecarga na base dos estratos arenosos e gretas de dessecação nos estratos pelíticos, com freqüente encurvamento dos flocos de lama. Esta fácies é interpretada como depósito de interdunas úmidas, efemeramente inundadas, como sugerido pela associação entre lâminas pelíticas, estruturas trativas subaquosas e feições de dessecação.

Ash (arenito com estratificação sub-horizontal): trata-se de arenitos muito finos sílticos com laminação milimétrica sub-horizontal marcada por segregação granular. Ocoore em camadas de espessura decimétrica e extensão lateral decamétrica. Nota-se freqüente bioturbação, a qual chega a descaracterizar a laminação original, dando ao conjunto aspecto maciço. Encontra-se intercalada às fácies Acb e Acbd. 

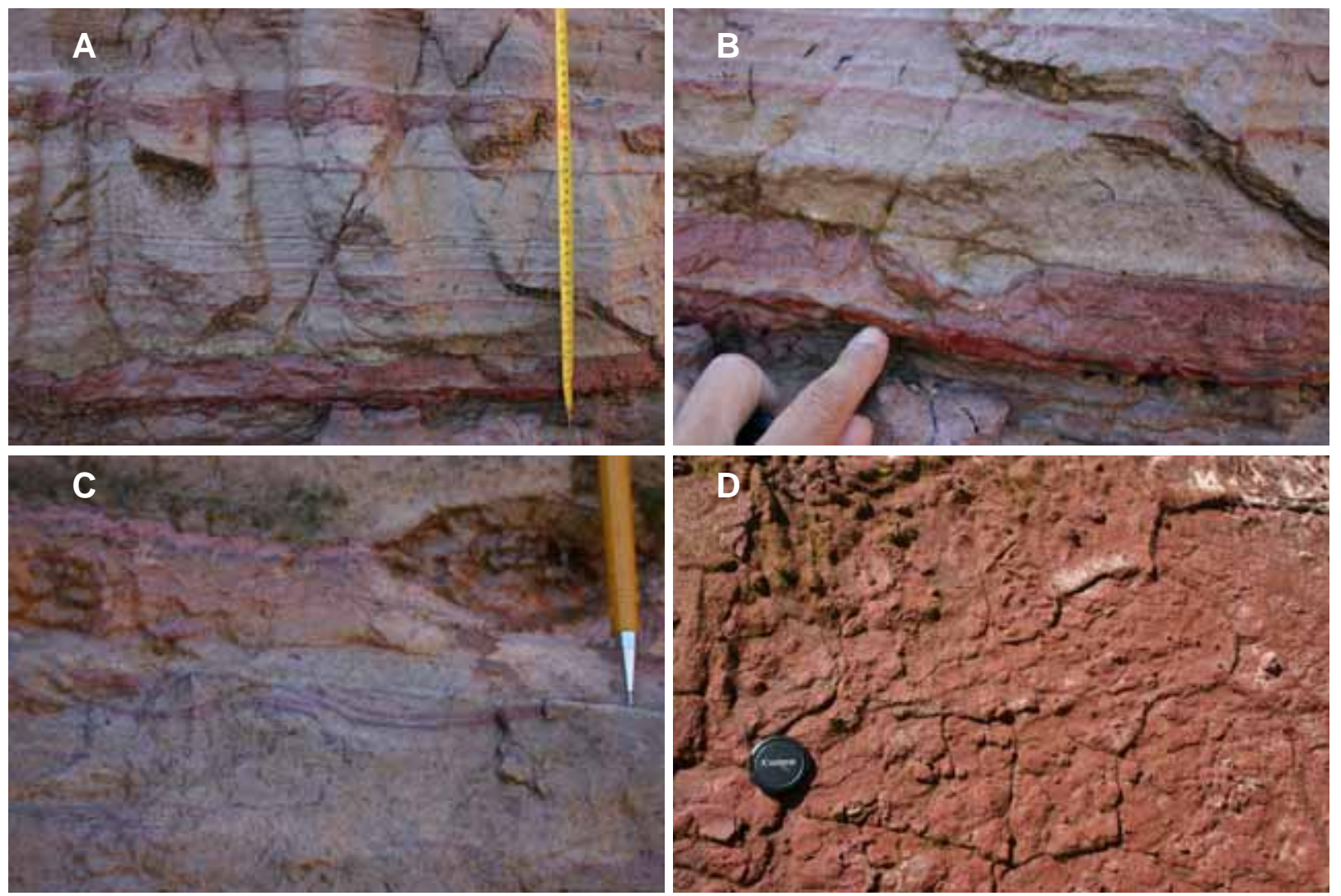

Figura 4.4 - Arenitos muito finos sílticos com estratificação heterolítica da fácies Acbl. Notar ritmicidade da intercalação arenito/lutito e sucessões decimétricas com diminuição da espessura das lâminas para o topo (fotografia A). Esta fácies pode apresentar também feições de sobrecarga (fotografia B), laminações onduladas (fotografia C) e gretas de dessecação preenchidas por areia (fotografia D, em planta). Areeiro CRS, rodovia SP225, km 74, próximo à Analândia.

Acp (arenito com intraclastos preenchendo paleocanais): fácies constituída por arenito fino a muito fino que preenche estrutura erosiva decamétrica de geometria irregular (canal), inferida pela associação entre marcas de sola e brecha basal, esta constituída por intraclastos do arenito que ocorre abaixo (Figura 4.5). Acima do horizonte basal de brecha intraclástica, os arenitos que preenchem 0 canal apresentam estratificação cruzada acanalada de ângulo de mergulho baixo. Esta fácies associa-se a processos subaquosos trativos efêmeros desenvolvidos nas depressões interdunas, provavelmente enxurradas ou wadi, conforme reconhecidos por Caetano-Chang \& Wu (1994). 

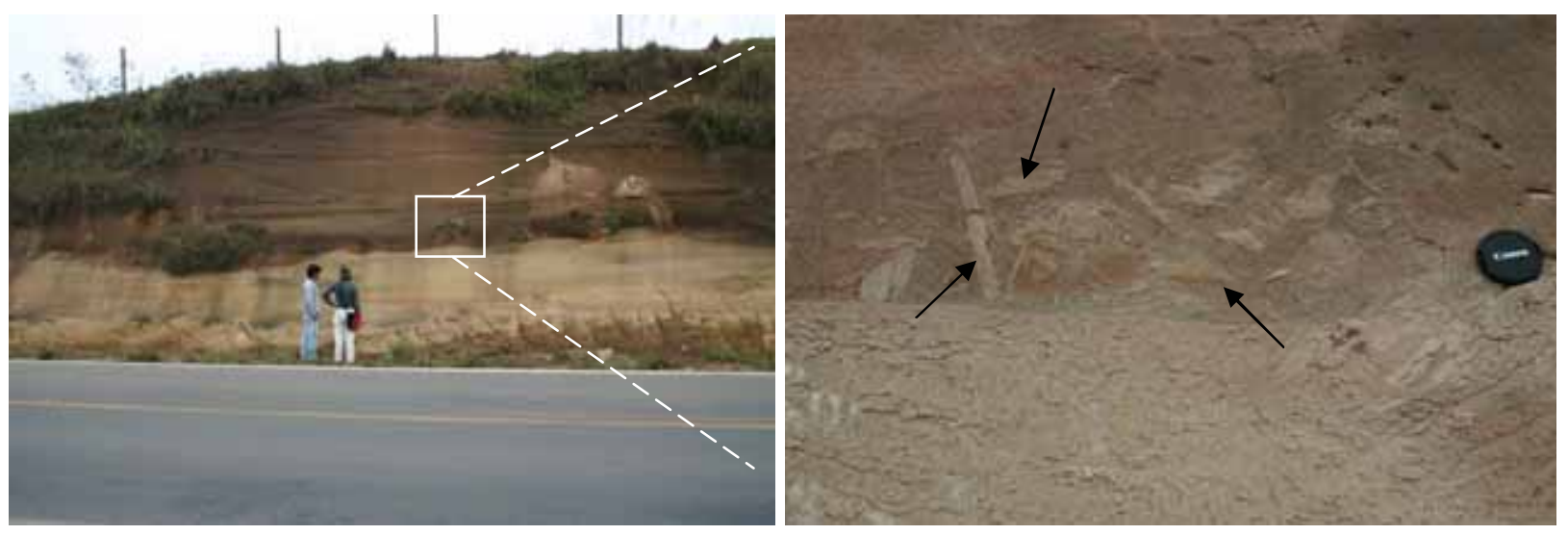

Figura 4.5 - Fácies Acp, em que a superfície basal irregular e a presença de brecha intraformacional com intraclastos tabulares de arenito (setas na foto da direita) permite interpretar escavação subaquosa da fácies subjacente (Aca, em tom mais claro). Afloramento da rodovia SP191, trecho entre Charqueada e São Pedro.

Am (arenito maciço): fácies composta por arenitos muito finos sílticos, sem estrutura interna, de espessura decimétrica a métrica e extensão decamétrica, em camadas aparentemente tabulares, amalgamadas. Esta fácies ocorre preferencialmente no domínio inferior do sistema eólico úmido, geralmente sobrepondo a fácies de brecha $(\mathrm{Bm})$, com a qual apresenta contato inferior irregular (Figura 4.6). Representa provavelmente o avanço de lençóis de areia, em estágio inicial de instalação do sistema eólico, em posição marginal em relação ao campo de dunas costeiro.

Bm (brecha intraformacional maciça com clastos de silexito): a fácies de brecha caracteriza-se por clastos de silexito ou intraclastos pelíticos (siltitos) dispersos na matriz areno-pelítica maciça (Figura 4.6). Ocorre na interface entre a sucessão de siltitos típicos da Formação Corumbataí/Teresina e os arenitos estratificados ou maciços da Formação Pirambóia e marca a passagem entre os sistemas deposicionais marinho raso e eólico úmido. Esta fácies corresponde à Camada Porangaba definida por Matos \& Coimbra (1997), cuja origem foi atribuída a processos de exposição subaérea, seguida de remobilização localizada, dos sedimentos marinhos (lutitos e calcilutitos) das formações Teresina e Corumbataí. 

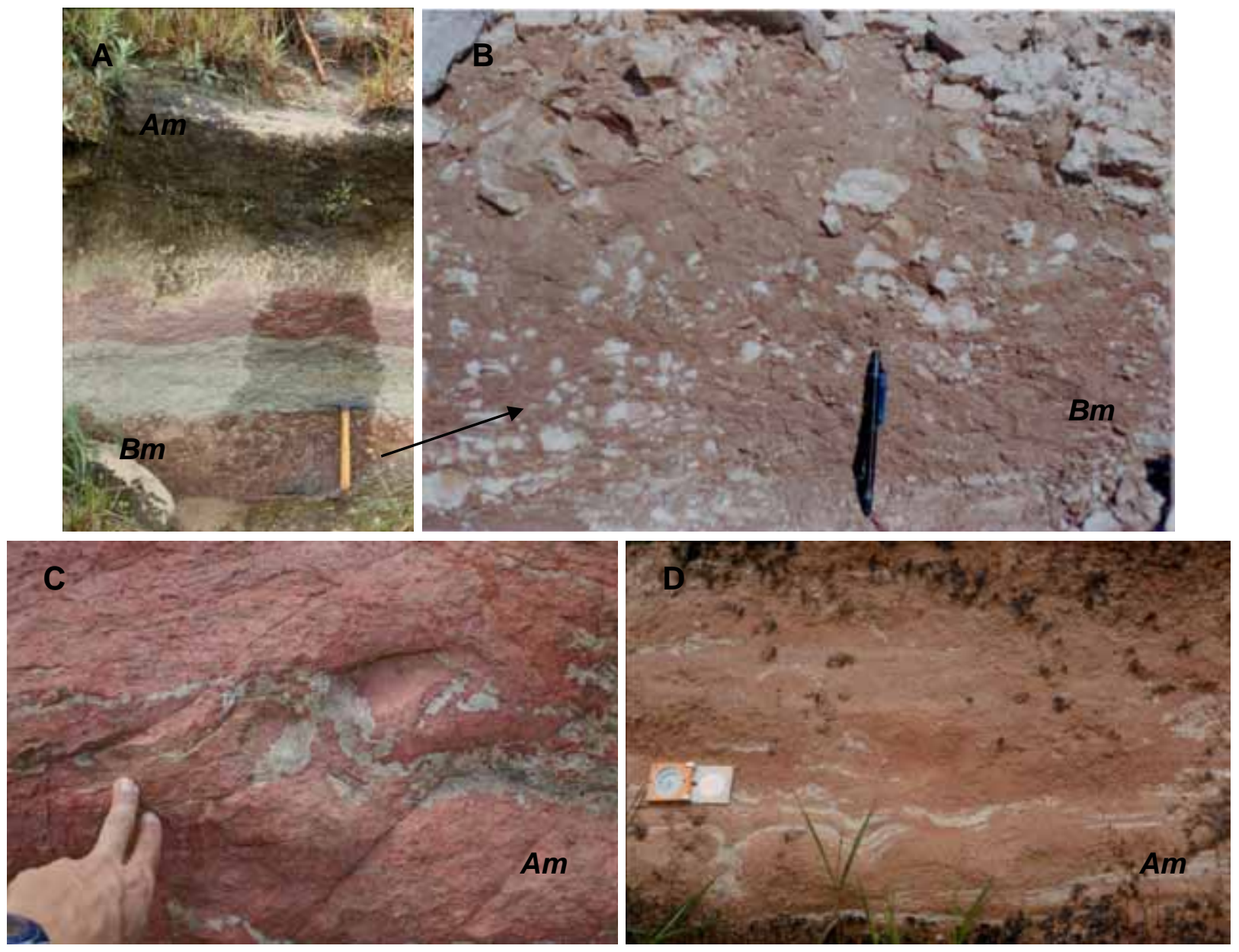

Figura 4.6 - Arenitos finos maciços da fácies Am, que podem ocorrer sobrepostos à fácies de brecha intraformacional (fácies $\mathrm{Bm}$ ), na base da sucessão do sistema eólico úmido Pirambóia. A, B e D: rodovia SP280, km 167. C: Rodovia SP191, trecho entre Ipeúna e Charqueada.

ACg (arenito conglomerático em estratos com gradação normal): arenitos conglomeráticos (a grânulos e seixos de até $5 \mathrm{~cm}$ de diâmetro) esbranquiçados, com estratos sub-horizontais ou cruzados granodecrescentes. Estratificações cruzadas acanaladas de pequeno porte (séries de espessura sub-métrica e extensão métrica), marcadas por concentração de grânulos e seixos orientados (Figura 4.7), são comuns. Localmente, encontram-se arenitos com estratos cruzados, de granulometria areia média a fina. Os processos sedimentares interpretados para esta fácies são de deposição trativa subaquosa em regime de fluxo inferior de alta energia a superior, com carga de sedimentos excessiva em relação à capacidade de transporte do fluxo. A sua deposição tem sido associada a depósitos de barras de rios entrelaçados que teriam se desenvolvido no final do sistema eólico úmido. Estes depósitos são equivalentes ao litotipo "Arenito Itirapina" de Caetano-Chang (1997). 

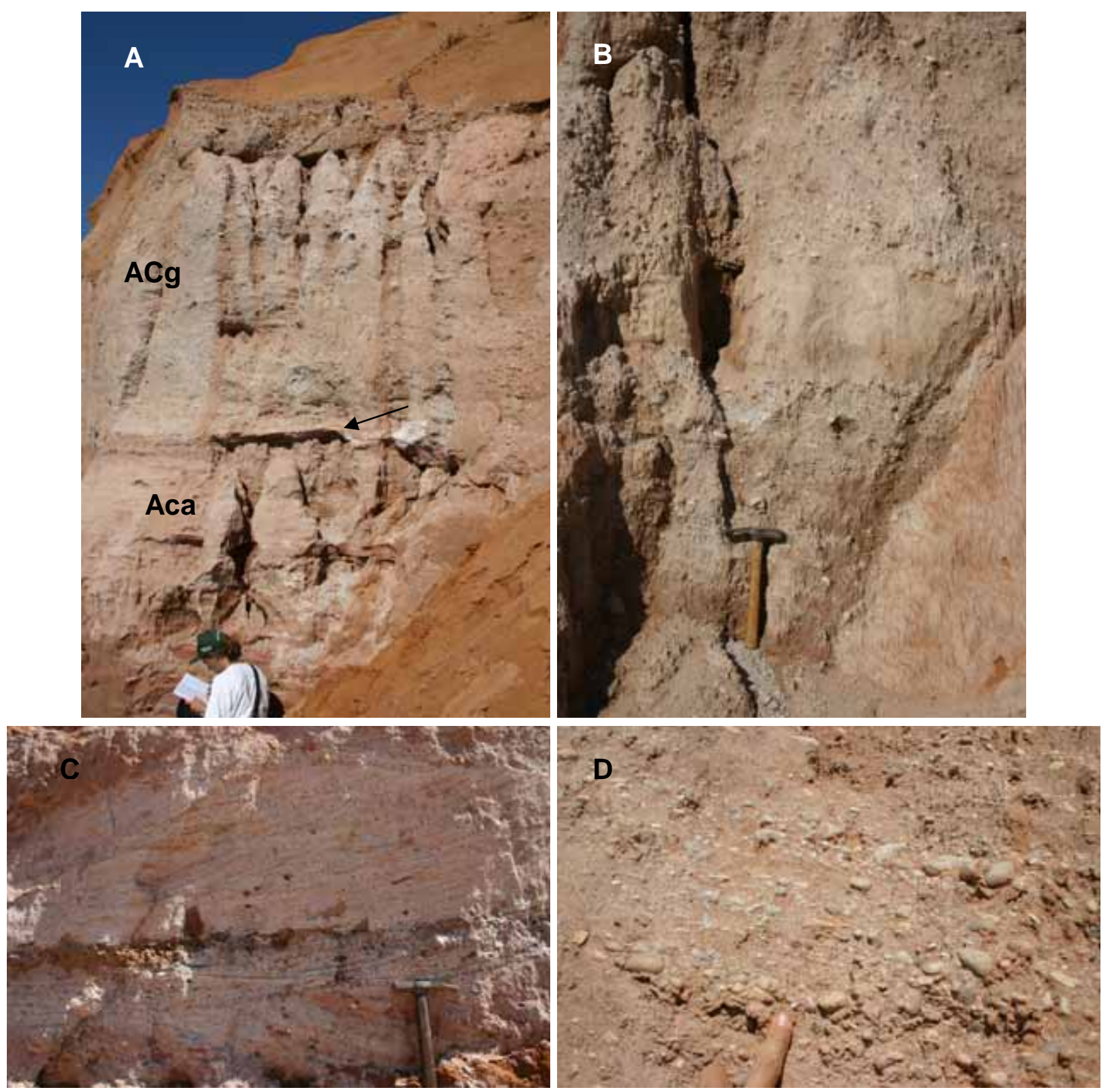

Figura 4.7 - Visão geral (fotografias A e B) dos arenitos conglomeráticos da fácies ACg, atribuído a depósitos de rios entrelaçados do sistema Pirambóia Superior. Na imagem A, a fácies $\mathrm{ACg}$ sobrepõe a fácies Aca e o contato entre as duas fácies faz-se através de superfície erosiva de baixo ângulo de mergulho com cimentação diferencial (seta). Notar séries de estratificações cruzadas de espessura decimétrica (fotografia C) e orientação longitudinal dos clastos rudáceos nos planos de estratificação (fotografia D). Areeiro Bragato, estrada vicinal (Estrada da Laranja) entre a SP225 e Descalvado.

No domínio inferior do sistema eólico Pirambóia, predominam as fácies Aca, Acb, Acbl, Acp, Ash e Am, podendo ou não ocorrer a fácies de brecha (Bm) na interface com o sistema marinho Passa Dois. Esta associação indica constante presença de água no sistema, com depressões interdunas intermitentemente alagadas. Nos locais onde a fácies de brecha é ausente, o contato basal com os 
siltitos subjacentes do Grupo Passa Dois é litologicamente abrupto e apresenta com freqüência estruturas deformacionais produzidas por sobrecarga dos arenitos maciços e estratificados (fácies Am, Acb, Aca) da Formação Pirambóia (Figura 4.8) sobre o topo das camadas de lutito da Formação Corumbataí. Este tipo de contato denota não ter havido hiato de tempo significativo entre a deposição das duas unidades, de tal forma que os sedimentos abaixo estariam ainda inconsolidados quando do avanço das primeiras frentes de dunas. Outro aspecto que reforça esta hipótese refere-se ao fato de os siltitos do topo da Formação Teresina/Corumbataí tornarem-se gradualmente mais ricos em areia fina, possivelmente depositada a partir de carga em suspensão trazida pelos ventos, ou mesmo em areia média, fração granulométrica tipicamente mais abundante no sistema Pirambóia que no Passa Dois (Figura 4.8).
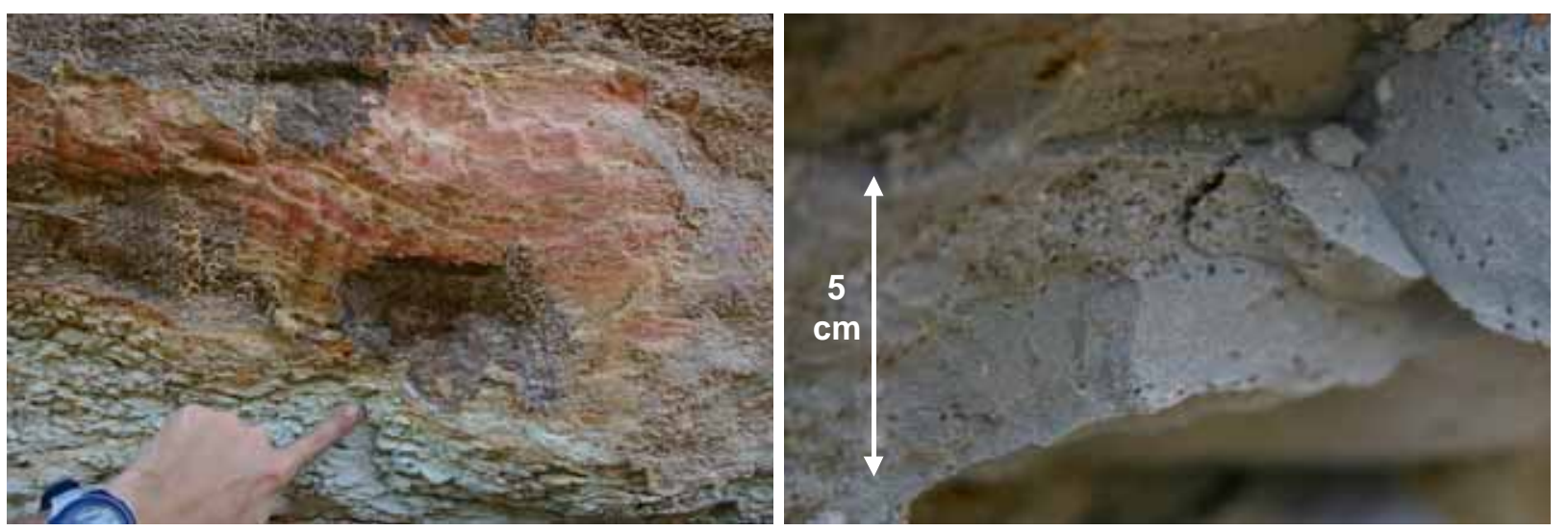

Figura 4.8 - Passagem entre o sistema marinho raso Passa Dois e sistema eólico úmido Pirambóia. Na fotografia da esquerda, notar feição de sobrecarga nos siltitos esverdeados (Formação Corumbataí) subjacentes à camada de arenitos estratificados. Na fotografia da direita, notar presença de areia média nos siltitos esverdeados. Corte da Ferrovia FEPASA, sob viaduto da Rodovia SP191, próximo à Ipeúna, SP.

No domínio superior do sistema eólico úmido Pirambóia, a associação de fácies é menos diversificada, caracterizada pelas fácies Aca, Acb, Acbd e Ash, com menor freqüência de estratos silto-argilosos. Esta associação permite interpretar decréscimo de umidade em relação à porção inferior da unidade, passando-se provavelmente a cenário de campo de dunas interior. Em cenário deste tipo, mas já no desfecho do sistema eólico úmido, passa a dominar a fácies $\mathrm{ACg}$, cuja associação esporádica com a fácies Aca demonstra a instalação de rios entrelaçados no sistema eólico. 


\subsection{Sistema eólico seco Botucatu}

O sistema eólico seco Botucatu é caracterizado pelas seguintes fácies:

Fácies AFca (arenito fino com estratificação cruzada de alto ângulo de mergulho): os arenitos desta fácies são de granulação tipicamente fina (areia fina e muito fina, localmente areia média), com laminação milimétrica bem marcada por segregação granular, dispostos em séries, de espessura métrica (de 3 a $5 \mathrm{~m}$ ), extensão decamétrica e geometria lenticular ou acanalada, de estratificações cruzadas tangenciais na base (Figura 4.9). São comuns estratos lenticulares centimétricos gerados por fluxo granular bem como laminação de marcas onduladas cavalgantes subcríticas ("pseudo-estratificação" sensu Hunter 1977). Esta fácies é característica do sistema eólico seco Botucatu, representando avanço de dunas em campo de dunas seco. Repete-se de forma monótona ao longo de toda sucessão aflorante. Localmente, são reconhecidas feições deformacionais, na forma de dobras e micro-falhas confinadas nos estratos cruzados, gerados por escorregamento de areia úmida na face de sotavento das dunas (Figura 4.9). Outra feição, menos comum, é a presença de icnofósseis, como pegadas de vertebrados de diâmetro centimétrico a decimétrico, mais facilmente reconhecíveis na superfície da estratificação (Figura 4.9).

Fácies AFcb (arenito fino com estratificação cruzada de baixo ângulo de mergulho): esta fácies é de ocorrência esporádica e ocorre principalmente no domínio basal da unidade. É constituída por arenitos finos ou bimodais (areia fina e areia média, excepcionalmente areia grossa), com estratificação cruzada de ângulo de mergulho geralmente menor que $15^{\circ}$, na forma de séries métricas lenticulares. Provavelmente corresponde a depressões interdunas secas, ou de periferia do campo de dunas, representantes da instalação do sistema eólico seco. 

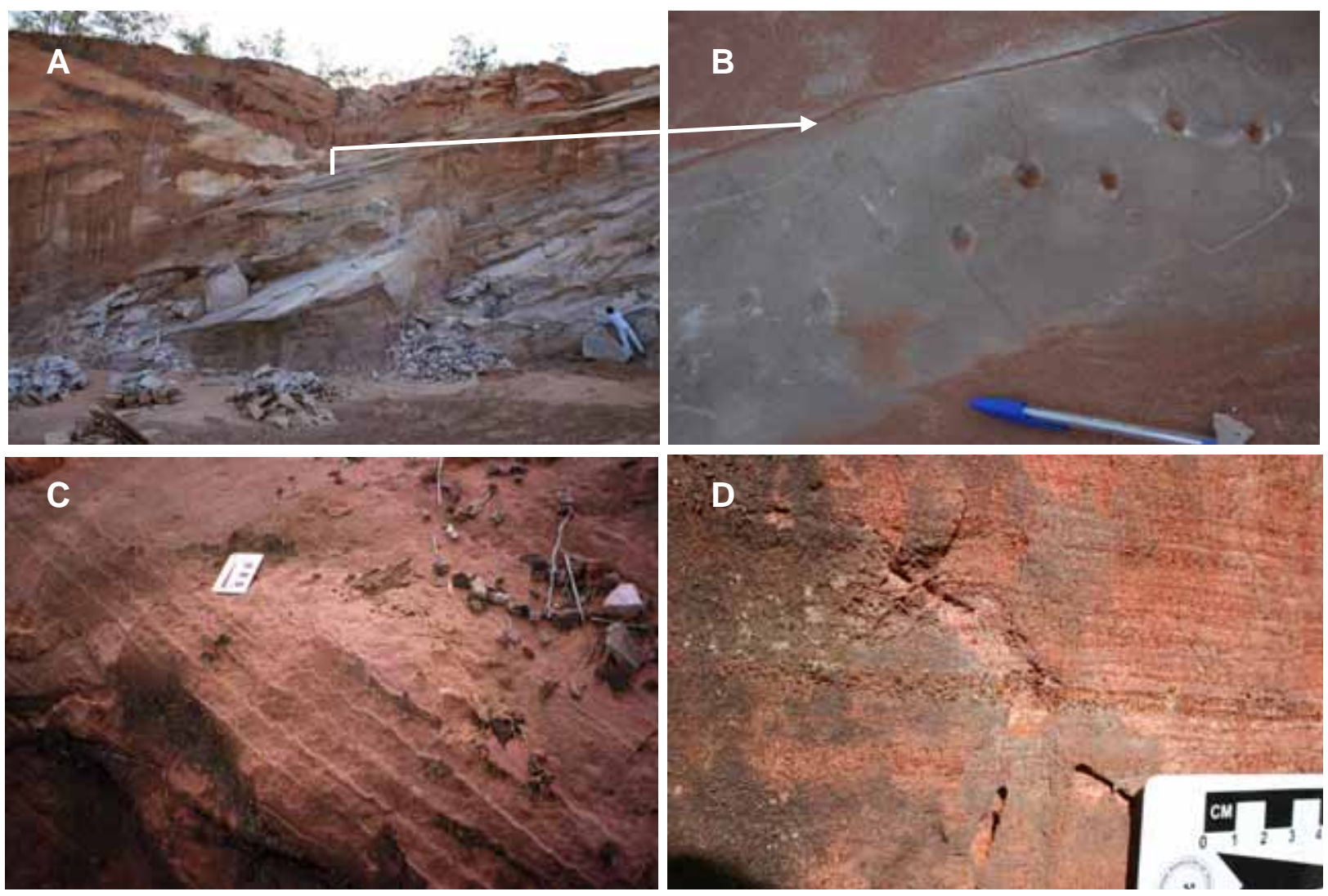

Figura 4.9 - Arenitos finos da fácies Afca e AFcb, do sistema eólico seco Botucatu. As estratificações cruzadas de Afca são de médio a grande porte (fotografia A) e localmente apresentam pegadas fósseis (gênero Brasilichnum, fotografia B). Na fotografia $C$, notar feições deformacionais devido a processos de escorregamento nas frentes de duna. $\mathrm{Na}$ fotografia $D$, observa-se bimodalidade granulométrica (areia fina versus areia média a grossa) em estratos de baixo ângulo de mergulho (fácies AFcb) do domínio inferior do sistema. A, B: Pedreira São Bento, Araraquara, SP; C: afloramento do km 12,7 da Rodovia SP287, entre Sarutaiá e Piraju, SP; D: afloramento da Rodovia SP253, nas imediações de São Simão, SP.

A distribuição faciológica monótona do sistema eólico seco Botucatu é característica marcante da unidade estratigráfica, reconhecida na grande maioria dos trabalhos prévios. O consenso sobre a origem eólica destes depósitos, desde os estudos pioneiros na bacia, como o de Washburne (1930), está relacionado certamente ao grande porte das estratificações cruzadas e às características texturais relativamente homogêneas dos arenitos, com quase nenhuma evidência de água no sistema.

O Quadro 4.1 resume as associações de fácies dos sistemas eólicos estudados e os principais processos sedimentares envolvidos. 
Quadro 4.1 - Resumo das fácies sedimentares e processos deposicionais dos sistemas eólicos Pirambóia e Botucatu (baseado em Giannini 2001)

\begin{tabular}{|c|c|c|c|}
\hline $\begin{array}{c}\text { Sistema } \\
\text { deposicional }\end{array}$ & $\begin{array}{c}\text { Associação de } \\
\text { fácies sedimentares }\end{array}$ & $\begin{array}{c}\text { Processos } \\
\text { sedimentares } \\
\text { principais }\end{array}$ & Cenário deposicional \\
\hline $\begin{array}{c}\text { Eólico seco } \\
\text { Botucatu }\end{array}$ & AFca, AFcb & $\begin{array}{c}\text { Migração de dunas } \\
\text { eólicas e draas }\end{array}$ & $\begin{array}{c}\text { Campo de dunas } \\
\text { eólicas com depressões } \\
\text { interdunas secas }\end{array}$ \\
\hline $\begin{array}{c}\text { Eólico úmido } \\
\text { Pirambóia } \\
\text { (superior) }\end{array}$ & $\mathrm{ACg}, \mathrm{Aca}$ & $\begin{array}{c}\text { Migração de barras de } \\
\text { rios entrelaçados e de } \\
\text { dunas eólicas }\end{array}$ & $\begin{array}{c}\text { Rios entrelaçados, } \\
\text { distais de leques } \\
\text { aluviais, em avanço } \\
\text { sobre campos de dunas } \\
\text { com planícies interdunas }\end{array}$ \\
\hline $\begin{array}{c}\text { Eólico úmido } \\
\text { Pirambóia } \\
\text { (inferior) }\end{array}$ & Aca, Acb, Acbd & $\begin{array}{c}\text { Migração de dunas } \\
\text { eólicas e umidificação e } \\
\text { liquidificação de areias de } \\
\text { interdunas }\end{array}$ & $\begin{array}{c}\text { Campo de dunas eólicas } \\
\text { costeiras com planícies } \\
\text { interdunas raramente } \\
\text { inundadas }\end{array}$ \\
\hline $\begin{array}{c}\text { Eólico úmido } \\
\text { Pirambóia } \\
\text { (inferior) }\end{array}$ & Aca, Acb, Acbl, Ash, & $\begin{array}{c}\text { Migração de dunas } \\
\text { eólicas e inundação de } \\
\text { interdunas, com } \\
\text { deposição subaquosa por } \\
\text { tração e suspensão }\end{array}$ & $\begin{array}{c}\text { Campo de dunas eólicas } \\
\text { costeiras com planícies } \\
\text { interdunas } \\
\text { freqüentemente } \\
\text { inundadas }\end{array}$ \\
\hline
\end{tabular}




\section{PETROGRAFIA}

\subsection{Textura e composição dos arenitos}

Os arenitos analisados das formações Pirambóia e Botucatu apresentam granulometria média e modal na fração areia fina e seleção boa a moderada. No caso de arenitos com granulometria bimodal, as frações são de areia fina e areia média, com seleção em geral boa por moda. Os arenitos da porção superior da Formação Pirambóia, de contexto flúvio-eólico, apresentam granulometria média e modal na fração areia média e seleção moderada a ruim (Tabela 5.1).

Em termos texturais, os arenitos eólicos das duas formações são bastante semelhantes entre si, pois apresentam amplitude estreita de variação da granulometria, de areia muito fina a areia média, com distribuição tanto unimodal quanto bimodal. As diferenças são sutis e residem no grau de arredondamento dos grãos, ligeiramente inferior nos arenitos da Formação Pirambóia. Os arenitos flúvioeólicos do topo da Formação Pirambóia, por sua vez, são em média mais grossos, mas apresentam ampla variação de granulometria (de areia muito fina a areia muito grossa), da seleção (<0,35 muito boa a 1,00, pobre) e do grau de arredondamento (de subangular a bem arredondado).

Tabela 5.1 - Parâmetros texturais dos arenitos das formações Pirambóia e Botucatu.

\begin{tabular}{|c|c|c|c|c|c|c|c|c|c|}
\hline \multicolumn{2}{|c|}{ Unidade } & $\begin{array}{l}\text { Gran. } \\
\text { Média }\end{array}$ & $\begin{array}{l}\text { Gran. } \\
\text { modal }\end{array}$ & Seleção & Moda 1 & Moda 2 & $\begin{array}{l}\text { Seleção } \\
\text { Moda } 1\end{array}$ & $\begin{array}{l}\text { Seleção } \\
\text { Moda } 2\end{array}$ & $\begin{array}{l}\text { Arred. } \\
\text { Médio }\end{array}$ \\
\hline \multirow{3}{*}{$\begin{array}{l}\text { BOT } \\
n=27\end{array}$} & MÉDIA & 210 & 195 & 0.57 & 135 & 324 & 0.42 & 0.38 & 0.52 \\
\hline & MÁX. & 314 & 300 & 0.82 & 210 & 437 & 0.56 & 0.50 & 0.70 \\
\hline & MíN. & 132 & 88 & 0.40 & 90 & 210 & 0.29 & 0.30 & 0.40 \\
\hline \multirow{3}{*}{$\begin{array}{c}\text { PIR } \\
n=25 \\
\end{array}$} & MÉDIA & 199 & 176 & 0.57 & 134 & 323 & 0.41 & 0.40 & 0.47 \\
\hline & MÁX. & 276 & 273 & 0.79 & 187 & 410 & 0.50 & 0.49 & 0.60 \\
\hline & MíN. & 108 & 105 & 0.37 & 105 & 230 & 0.26 & 0.34 & 0.40 \\
\hline \multirow{3}{*}{$\begin{array}{c}\text { PIR-SUP } \\
n=25\end{array}$} & MÉDIA & 393 & 389 & 0.67 & 151 & 433 & 0.43 & 0.38 & 0.46 \\
\hline & MÁX. & 1114 & 1091 & 1.36 & 212 & 771 & 0.64 & 0.58 & 0.70 \\
\hline & MíN. & 100 & 105 & 0.27 & 105 & 230 & 0.38 & 0.29 & 0.30 \\
\hline
\end{tabular}

OBS.: Valores de granulometria em micrômetros; valores de arredondamento segundo escala de Powers (1953).

Em relação à composição mineralógica do arcabouço, os arenitos estudados são classificados como quartzo-arenitos e arenitos feldspáticos (Dott 1964) ou subarcóseos (Folk 1968), conforme pode ser visto na Figura 5.1. 
$\operatorname{Dott}(1964) \quad \mathbf{Q}$

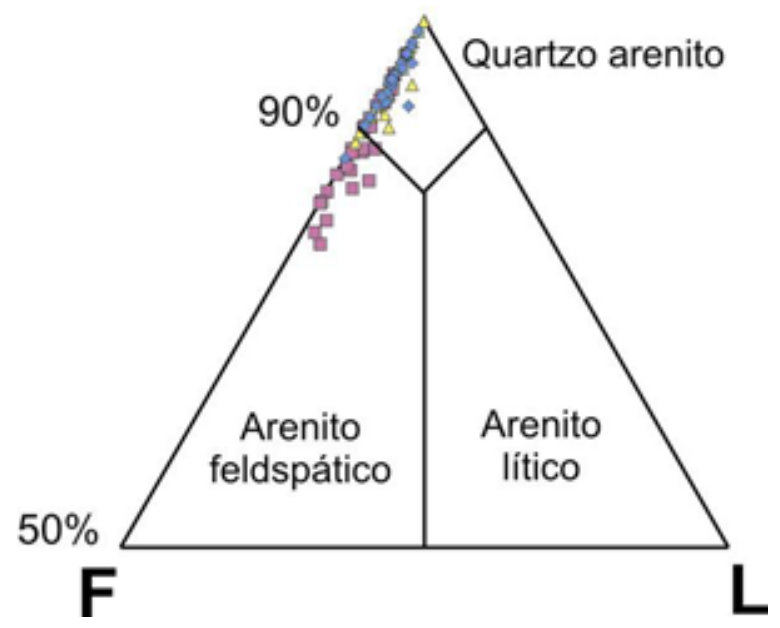

Folk (1968)

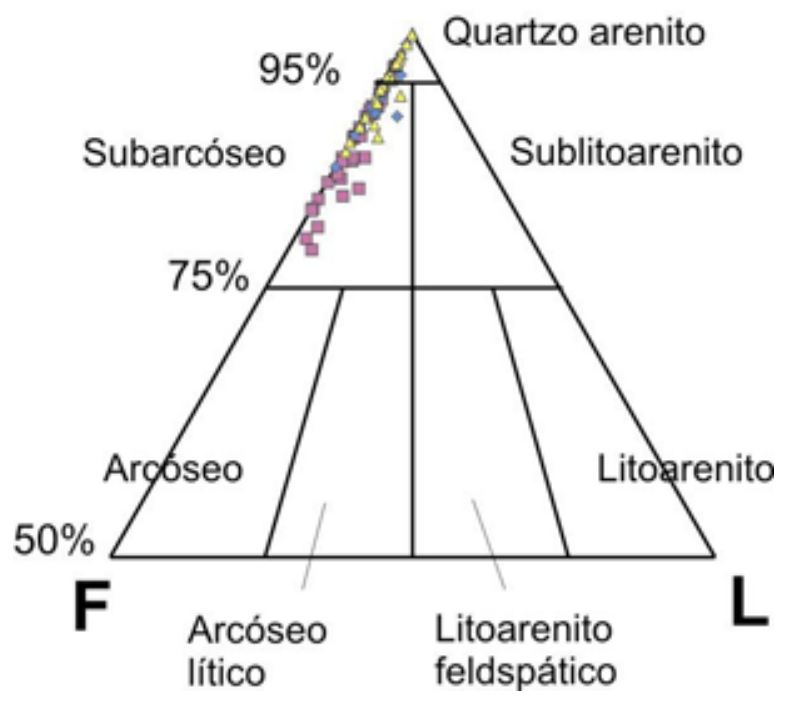

Figura 5.1 - Composição mineralógica do arcabouço dos arenitos das formações Pirambóia e Botucatu lançada nos diagramas de classificação petrográfica de Dott (1964) e Folk (1968). Diamante azul - Formação Botucatu; quadrado rosa - Formação Pirambóia (eólico); triângulo amarelo - porção superior da Formação Pirambóia (flúvio-eólica).

Os arenitos da Formação Botucatu e da porção superior da Formação Pirambóia são essencialmente quartzosos (sensu Dott 1964), com proporção menor de arenitos feldspáticos, enquanto os arenitos eólicos da Formação Pirambóia são predominantemente feldspáticos (sensu Dott 1964) e subarcoseanos (sensu Folk 1968). Estas características são observadas tanto nas amostras de afloramento quanto nas de subsuperfície. Isto significa que mesmo em condições aflorantes, onde o intemperismo tende a lixiviar os grãos quimicamente instáveis, os arenitos eólicos da Formação Pirambóia apresentam conteúdo de feldspato acima de $10 \%$. Em contraposição, os arenitos da Formação Botucatu, em subsuperfície, em geral são pobres neste mineral, com conteúdo de no máximo $13 \%$ (poço de Batatais). Não é possível estabelecer uma relação direta entre conteúdo de feldspato e distância da borda da bacia ou profundidade de ocorrência (Figura 5.2). Estes dados contrapõem-se à interpretação de França et al. (2003) de que os arenitos da Formação Botucatu teriam composição original feldspática ou subarcoseana e tornaram-se quartzosos na zona aflorante, por modificações ocorridas na telodiagênese. 


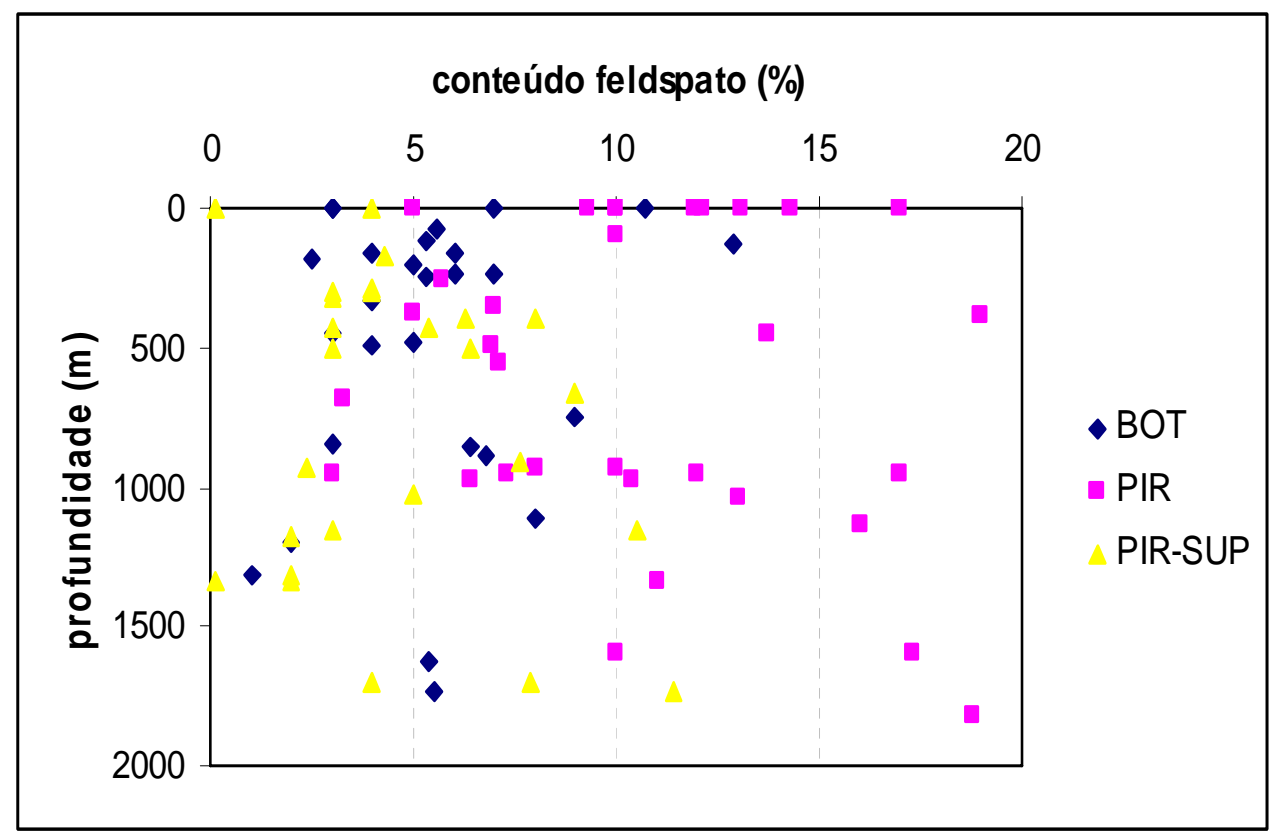

Figura 5.2 - Relação entre conteúdo de feldspato do arcabouço dos arenitos e profundidade de amostragem. BOT: Formação Botucatu, PIR: Formação Pirambóia, PIR-SUP: porção superior da Formação Pirambóia, de contexto fúvio-eólico.

A porção superior do sistema eólico Pirambóia em superfície é nitidamente rudácea, com predomínio de arenitos grossos a conglomeráticos, com seleção moderada a ruim e arredondamento variável, dispostos em estratos cruzados acanalados com gradação interna, atribuídos a processos trativos subaquosos (contexto de barras fluviais). Em subsuperfície, este domínio é também caracterizado pela presença de arenitos conglomeráticos, no entanto ressaltam-se as intercalações de arenitos finos, por vezes bimodais, com bom arredondamento e seleção, típicos de processos de remobilização eólica. Nos perfis de poços, os horizontes eólicos geralmente sobrepõem os horizontes tipicamente subaquosos e demarcam localmente a interface discordante entre os sistemas eólicos Pirambóia, abaixo, e Botucatu, acima.

\subsection{Amostras de superfície}

As fácies sedimentares dos sistemas eólicos Pirambóia e Botucatu, reconhecidas na zona aflorante, apresentam características petrográficas texturais, mineralógicas e diagenéticas que Ihes permitem serem agrupadas em dois grandes domínios faciológicos, com conotação genética abrangente em termos de processo sedimentar: fácies eólicas, correspondentes aos depósitos de duna e interduna, e 
fácies flúvio-eólica, relativa aos depósitos de canais e barras de rios entrelaçados associados ao sistema eólico. As principais características petrográficas destes domínios faciológicos em cada uma das unidades encontram-se descritas no Quadro 5.1.

Quadro 5.1 - Características petrográficas nos domínios genéticos dos sistemas eólicos Pirambóia e Botucatu

\begin{tabular}{|c|c|}
\hline Domínios genéticos & Descrição \\
\hline \multicolumn{2}{|l|}{$\begin{array}{c}\text { Sistema eólico } \\
\text { Pirambóia }\end{array}$} \\
\hline $\begin{array}{l}\text { Fácies eólica - } \\
\text { duna } \\
\text { (Figura 5.3) }\end{array}$ & $\begin{array}{l}\text { Arenitos finos a médios, em geral feldspáticos ( } \geq 10 \%) \text {, } \\
\text { caracterizados por segregação granular nítida e orientação dos } \\
\text { grãos alongados, seleção granulométrica moderada a boa por } \\
\text { moda, grãos arredondados a subarredondados, arcabouço aberto, } \\
\text { compactação química incipiente sugerida por contatos pontuais e } \\
\text { planares, cutícula e franja de cimento argilo-limonítico e } \\
\text { porosidade intergranular e intragranular (alveolar e móldica). }\end{array}$ \\
\hline $\begin{array}{l}\text { Fácies eólica - } \\
\text { interduna } \\
\text { (Figura } 5.4 \text { ) }\end{array}$ & $\begin{array}{l}\text { Arenitos muito finos a médios, com intercalações pelíticas, e } \\
\text { composição feldspática ( } \geq 10 \%) \text {, caracterizados por bimodalidade } \\
\text { textural (areia fina e areia média), seleção granulométrica } \\
\text { moderada, grãos subarredondados a subangulares, arcabouço } \\
\text { aberto, segregação granular, feições de compactação química } \\
\text { incipiente (contatos intergranulares pontuais e planares), cutícula } \\
\text { argilo-limonítica, cimento intersticial de argilominerais e } \\
\text { porosidade intergranular e intragranular (alveolar e móldica). }\end{array}$ \\
\hline $\begin{array}{l}\text { Fácies flúvio-eólica } \\
\text { (Figura } 5.5 \text { ) }\end{array}$ & $\begin{array}{l}\text { Arenitos finos a grossos e conglomeráticos, pobres em feldspato } \\
(<10 \%) \text { e relativamente ricos em líticos estáveis (quartzito 9\%), } \\
\text { caracterizados por seleção moderada a pobre, grãos arredondados } \\
\text { a angulares, granodecrescência por lâmina, orientação dos grãos } \\
\text { alongados, feições de compactação química moderada (contatos } \\
\text { intergranulares planares e côncavo-convexos), sobrecrescimento } \\
\text { sintaxial de quartzo precoce, cutículas argilo-limoníticas delgadas } \\
\text { ou inexistentes e porosidade intergranular e móldica. }\end{array}$ \\
\hline \multicolumn{2}{|l|}{$\begin{array}{c}\text { Sistema eólico } \\
\text { Botucatu }\end{array}$} \\
\hline $\begin{array}{l}\text { Fácies eólica - } \\
\text { duna } \\
\text { (Figura } 5.6 \text { e } 5.7 \text { ) }\end{array}$ & $\begin{array}{l}\text { Arenitos finos a muito finos, localmente médios, pobres em } \\
\text { feldspato (<10\%), caracterizados por bimodalidade textural (areia } \\
\text { fina e muito fina ou areia fina e média), segregação granular nítida } \\
\text { por variação granulométrica e de empacotamento, seleção boa por } \\
\text { moda, grãos bem arredondados a arredondados, laminação pin- } \\
\text { stripe, orientação dos grãos alongados, feições de compactação } \\
\text { química incipiente (contatos pontuais e planares), cutículas argilo- } \\
\text { limoníticas, cimento intersticial de argilominerais e porosidade } \\
\text { intergranular e intragranular (alveolar e móldica). Pode apresentar } \\
\text { cimento silicoso (opala e calcedônia) poro-envolvente e intersticial. }\end{array}$ \\
\hline
\end{tabular}

Estas características serviram para orientar a interpretação quanto à posição estratigráfica e faciologia das amostras de calha. Os principais critérios texturais adotados para a individualização dos agrupamentos de fácies foram: 1) diâmetro modal e bimodalidade textural; 2) seleção e arredondamento e 3) cimento eodiagenético. 

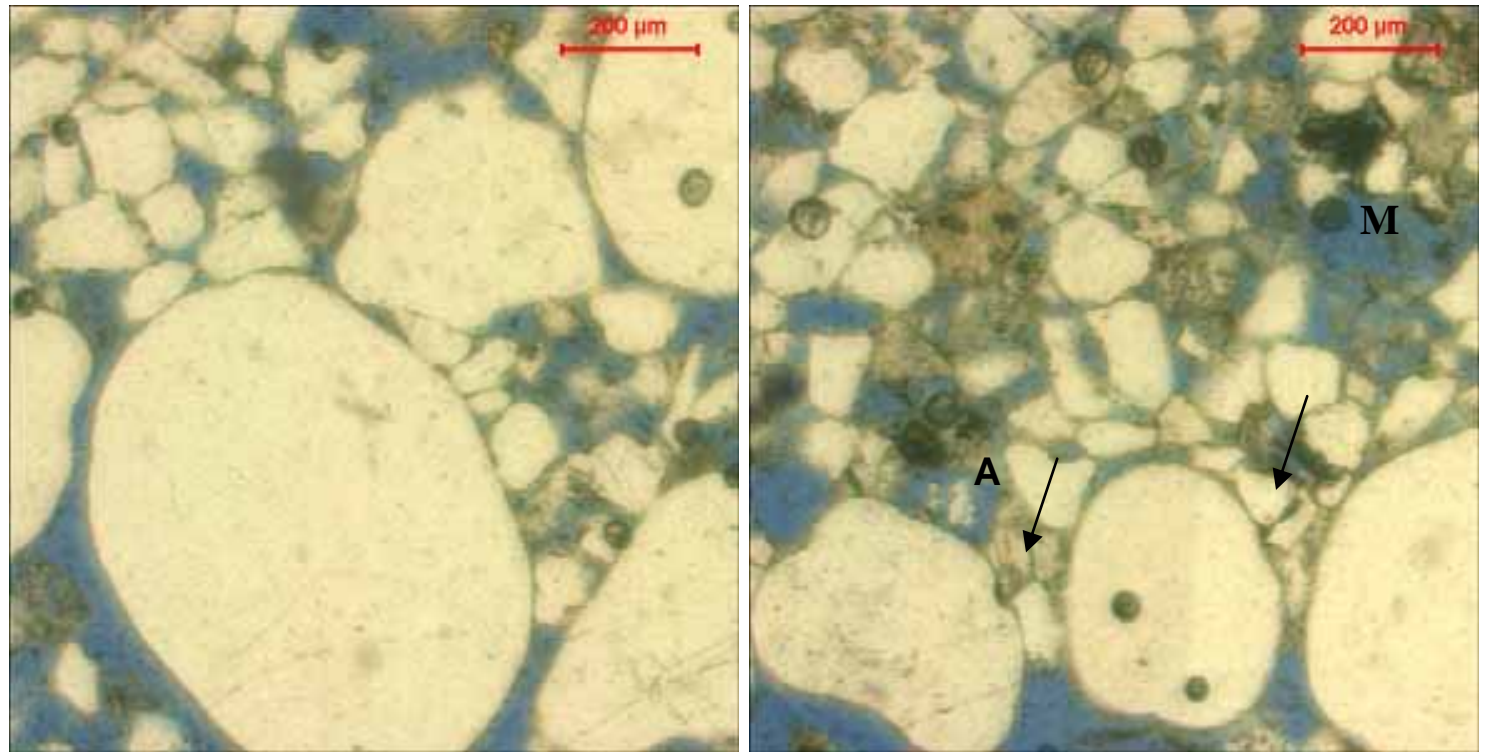

Figura 5.3 - Arenitos finos a médios da fácies eólica de duna do sistema Pirambóia. Notar bimodalidade textural (modas nas frações areia fina e areia média), grãos arredondados, na moda areia média, a subarredondados, na moda areia fina, seleção boa por moda, arcabouço aberto $\left(\mathrm{IP}_{\mathrm{kp}}=29,7 \%\right)$ e contatos intergranulares pontuais e planares. $\mathrm{Na}$ imagem da direita, ressalta-se a segregação granular marcada por diferenças de granulação (base: areia média, topo: areia fina). Notar que os grãos mais finos preenchem parcialmente os espaços intergranulares da lâmina inferior (setas). Nicóis paralelos. M: porosidade móldica; A: porosidade alveolar em feldspato. Arenitos com estratificações cruzadas de alto ângulo, porção inferior da Formação Pirambóia, ponto SP-09C, São Pedro, SP.
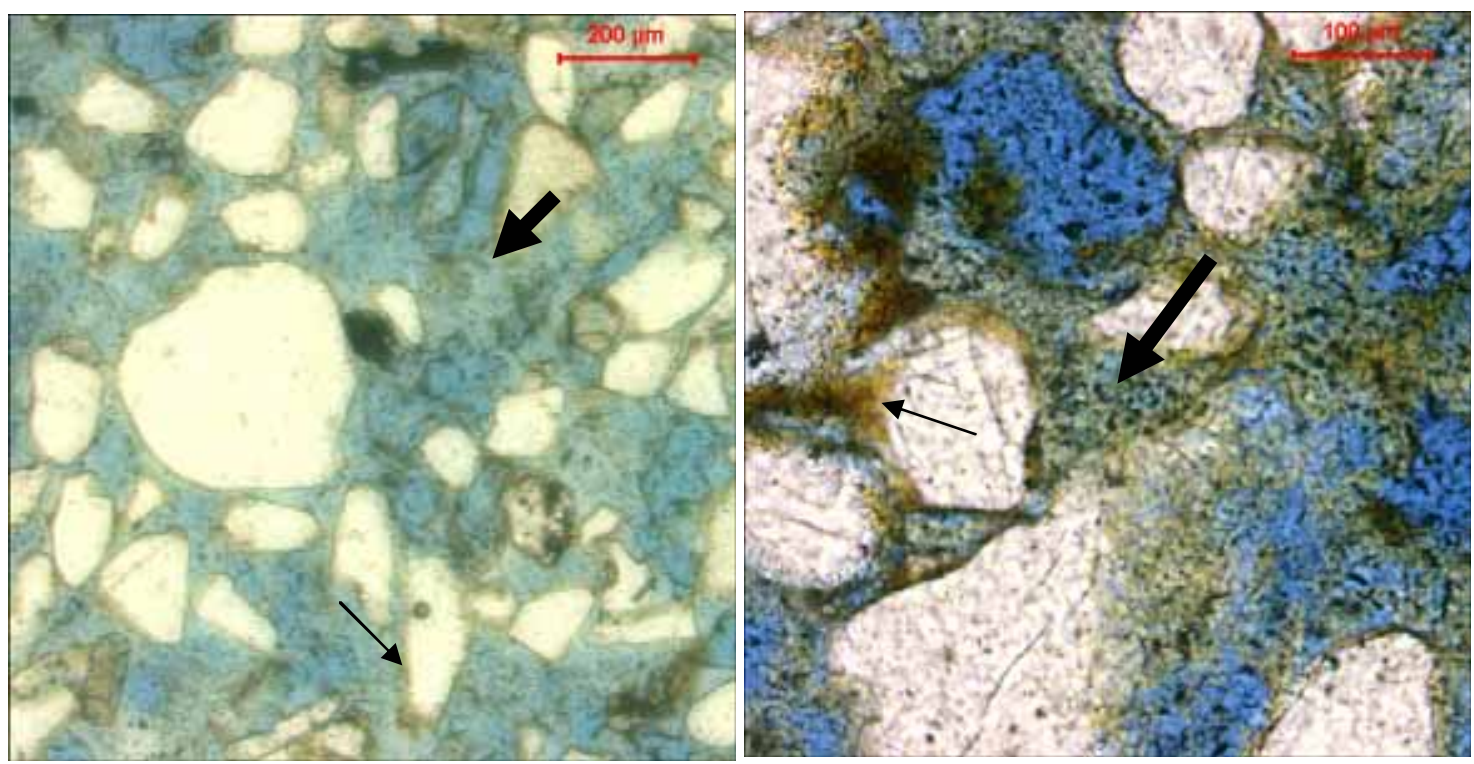

Figura 5.4 - Arenitos finos a médios da fácies eólica de interdunas do sistema Pirambóia. Notar bimodalidade textural (modas nas frações areia fina e areia média), seleção moderada, grãos em geral subarredondados e arcabouço aberto ( I $_{\mathrm{Kp}}=17,2 \%$ ). Não se identifica segregação granular nítida nesta lâmina. Na fotomicrografia de detalhe (direita), ressaltam-se cutículas argilo-ferruginosas envolventes (seta fina), de textura sacaroidal e espessura variável, e cimento de argilominerais intersticial (seta grossa), que sob nicóis cruzados apresenta baixa birrefringência. Este último cimento, na fotomicrografia da esquerda, apresenta aspecto de "manchas esbranquiçadas", ocupando grande parte do espaço intergranular. Notar elevado volume de porosidade intragranular (móldica e alveolar) e intracimento (microporosidade). Nicóis paralelos. Arenitos finos com 
estratificação cruzada de baixo ângulo de mergulho, porção inferior da Formação Pirambóia, ponto SP-07h, São Pedro, SP.
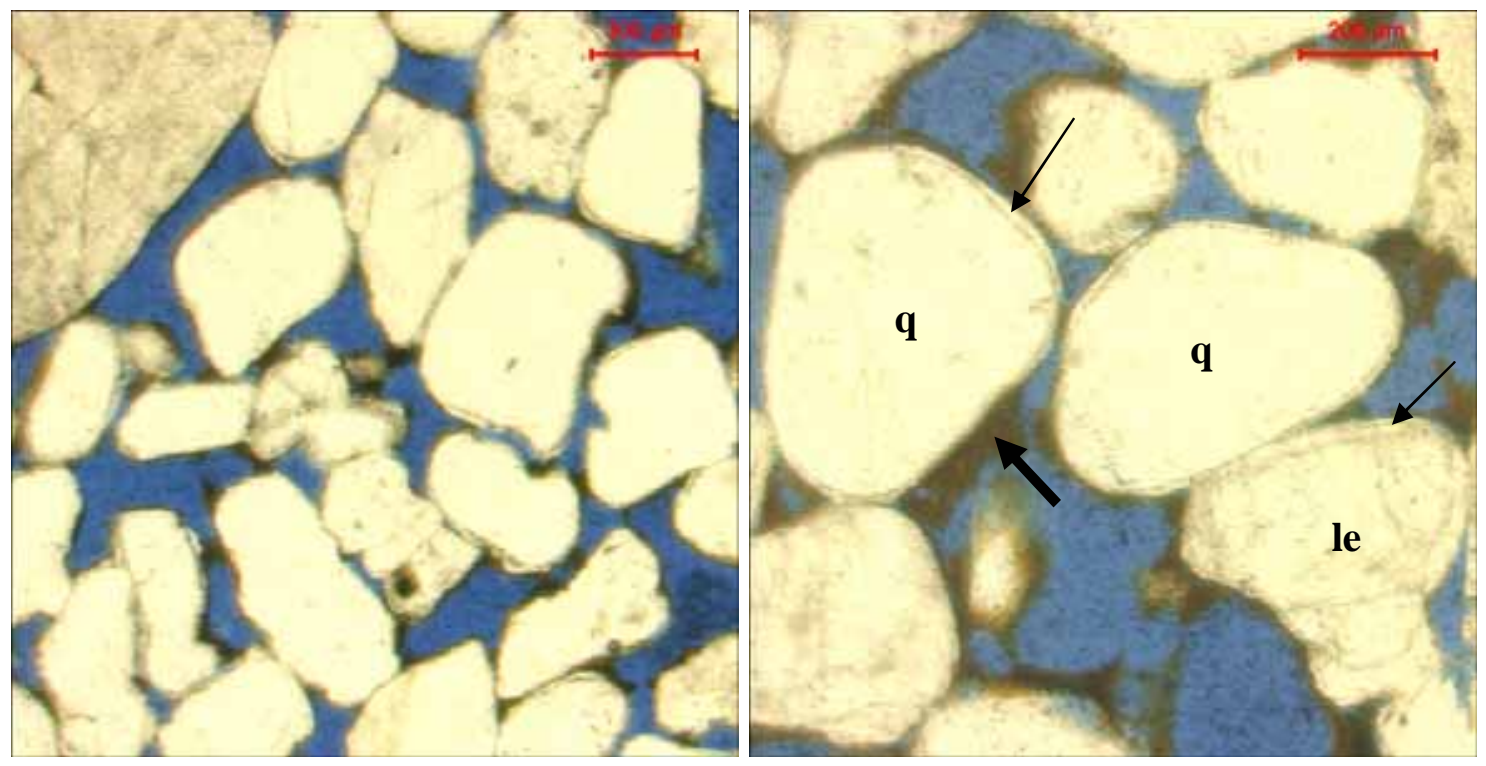

Figura 5.5 - Arenitos médios a grossos da fácies flúvio-eólica (fluvial) da porção superior do sistema Pirambóia, caracterizados por grande amplitude de variação granulométrica, de areia fina (diâmetro mínimo $150 \mu \mathrm{m})$ a areia muito grossa (1200 $\mu \mathrm{m}$ ), com granodecrescência ascendente nos estratos subcentimétricos. Notar arcabouço aberto $(\mathrm{IPKp}=20,5 \%)$ e predomínio de contatos intergranulares planares. Na fotomicrografia de detalhe à direita, pode-se visualizar sobrecrescimento sintaxial (setas finas) de quartzo (q) em grãos uni e policristalinos de fragmento de rocha (le), além de espessas cutículas argiloferruginosas (rims) revestindo as bordas dos poros (prováveis argilas infiltradas, seta grossa). Notar também alta porosidade intergranular. Nicóis paralelos. Arenitos conglomeráticos com estratos gradados, porção superior da Formação Pirambóia, ponto MS07c, Ivaiporã, PR.
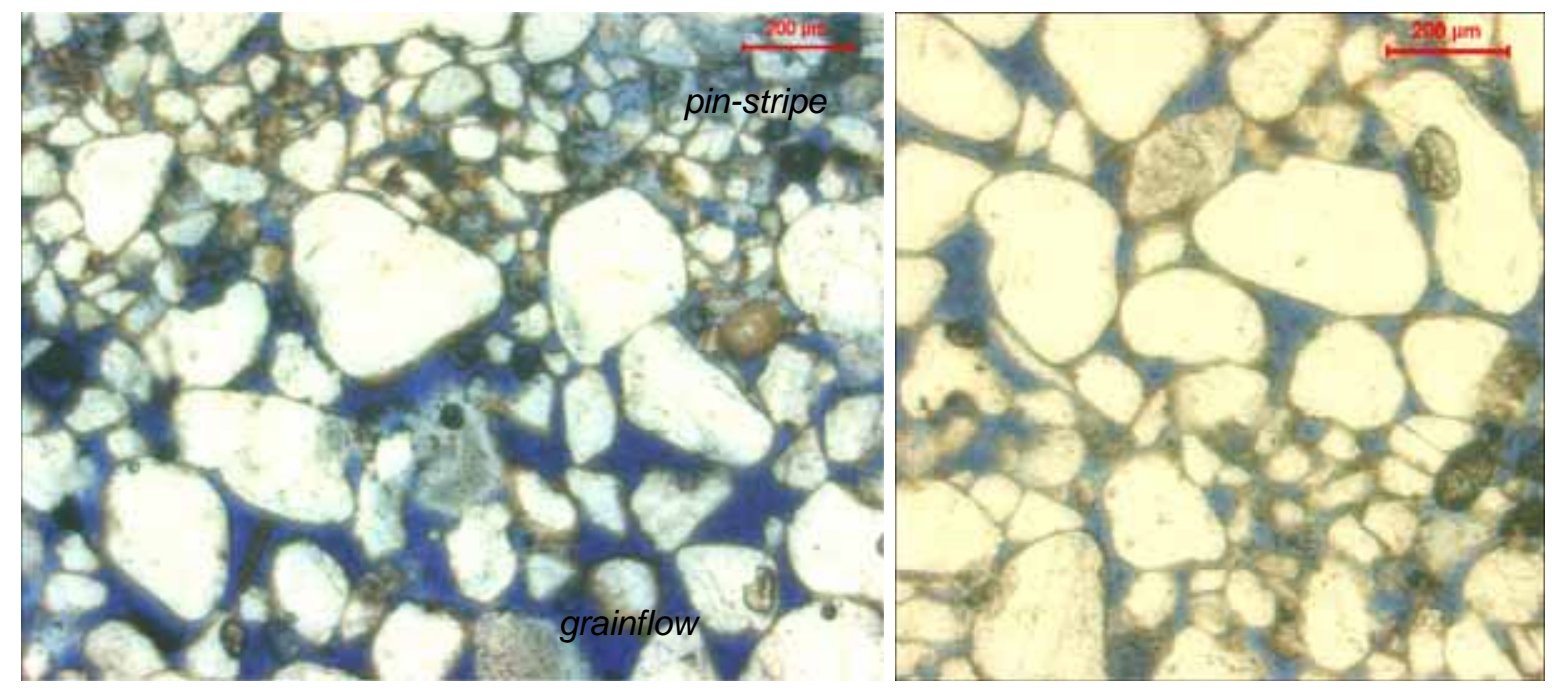

Figura 5.6 - Arenitos muito finos a finos da fácies eólica de duna do sistema Botucatu. Notar nítida segregação granular por variação granulométrica (frações areia fina e areia muito fina) e de empacotamento. Na fotomicrografia da esquerda, o estrato mais fino apresentase mais cimentado (cutículas argilosas vermelhas), uma das características típicas, ao microscópio, da laminação pin-stripe; o estrato mais grosso apresenta empacotamento mais frouxo, com contatos intregranulares pontuais e grãos "flutuantes", indicativos de deposição 
por fluxo granular (grainflow). Notar bom arredondamento dos grãos e boa seleção por estrato. Nicóis paralelos. Arenitos muito finos com estratificações cruzadas de ângulo alto e grande extensão lateral, porção inferior da Formação Botucatu, ponto SM-02c, Santa Maria da Serra, SP.

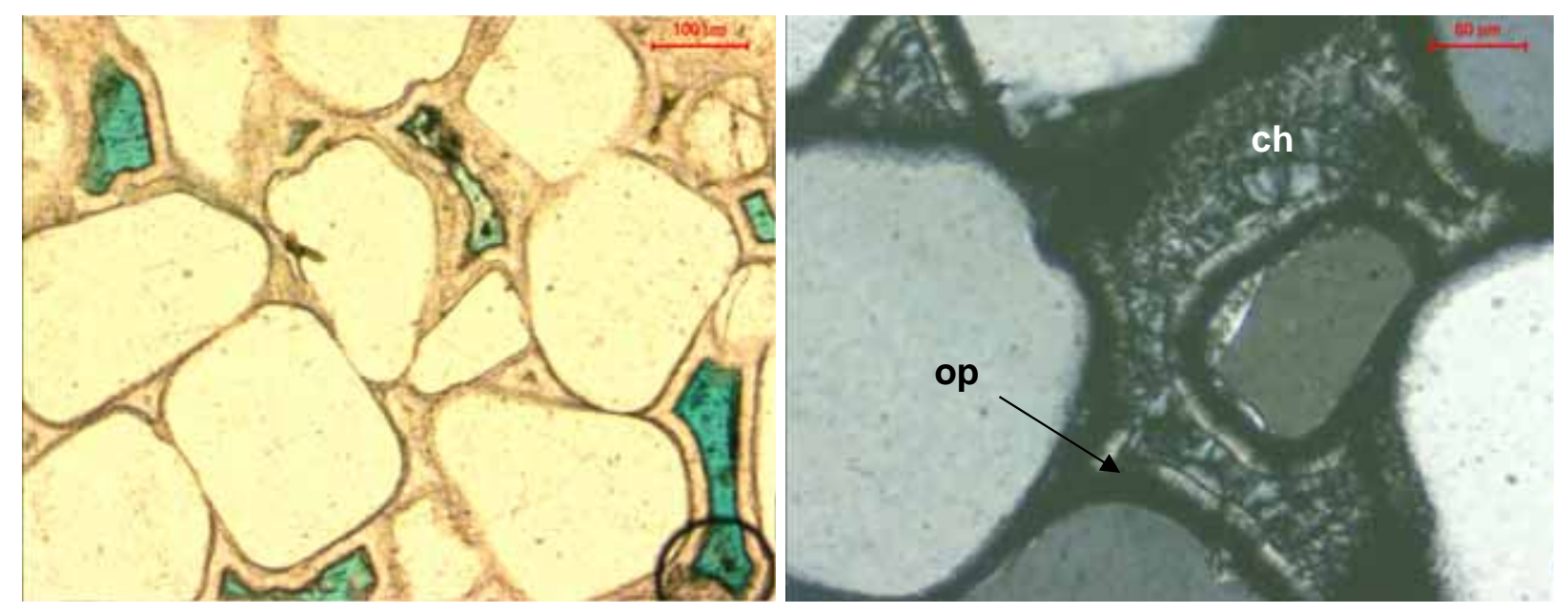

Figura 5.7 - Arenitos finos de fácies eólicas de duna do sistema Botucatu, com cimento silicoso. Os cimentos são franjas poro-envolventes de opala (op) isótropa (imagem da direita, com nicóis cruzados) e calcedônia fibrorradiada intersticial (ch), esta na forma de mosaicos. Notar porosidade remanescente à silicificação (tom azulado) na imagem da esquerda, com nicóis paralelos. Pedreira São Bento, Distrito do Ouro, Araraquara, SP.

Com relação às fácies eólicas, uma característica típica é a bimodalidade textural. Os arenitos do sistema eólico Pirambóia apresentam distribuição granulométrica nas frações areia fina e areia média e seleção $(\sigma>0,5)$ e grau de arredondamento moderados. Entre as fácies de interdunas e dunas, o principal critério de diferenciação é, respectivamente, a presença ou não de finos, na forma de estratos silto-argilosos ou matriz infiltrada mecanicamente. Outro critério distintivo é que a fácies de interdunas geralmente apresenta granulometria modal e média mais fina comparativamente à fácies de duna. No sistema eólico Botucatu, os arenitos apresentam distribuição nas frações areia fina (às vezes muito fina) e areia média, seleção boa a moderada e alto grau de arredondamento da moda areia média. A segregação granular por variação de granulometria e de empacotamento e a orientação dos grãos são características típicas das fácies de dunas dos dois sistemas eólicos.

No caso das fácies flúvio-eólicas da porção superior do sistema eólico Pirambóia, a granulometria modal e média na fração areia média, o conteúdo de fragmentos líticos estáveis (quartzito) e o grau de arredondamento variável (subangular a arredondado) são considerados critérios distintivos. A designação flúvio-eólica é aqui utilizada tanto para os arenitos rudáceos (tipicamente fluviais) 
quanto para os arenitos finos, com bom arredondamento e seleção (tipicamente eólicos), intercalados ou sobrepostos aos primeiros.

Com relação aos componentes diagenéticos, a diferença mais marcante entre os domínios genéticos de fácies eólicas e flúvio-eólica é a presença, no primeiro grupo, de cutículas argilo-ferruginosas precoces, envolvendo quase que totalmente a superfície dos grãos detríticos. Os arenitos conglomeráticos, típicos do contexto superior do sistema eólico Pirambóia, de origem fluvial, apresentam cutícula muito tênue (linha de sujeira), perceptível nos grãos com sobrecrescimento sintaxial de quartzo. Os cimentos de argilominerais, formando franjas ou ocupando o espaço intersticial, são comuns a todos os litotipos descritos (arenitos de dunas, interdunas e lags de canal fluvial).

A porosidade secundária intragranular, principalmente em grãos de feldspato potássico e plagioclásio alveolares ou completamente lixiviados (poros móldicos), é característica comum nas rochas superficiais, denotando influência do intemperismo químico telogenético.

\subsection{Petrofácies}

A individualização de petrofácies consiste no agrupamento de rochas sedimentares que possuam atributos similares de textura, petrotrama e mineralogia, resultantes da combinação e sobreposição de aspectos deposicionais por aspectos diagenéticos. O uso do termo petrofácies nesta Tese constitui uma variante da própria definição de fácies ou litofácies (sensu Walker 1980). Desse modo, as petrofácies são consideradas descritivas por natureza e representam um conjunto de características físicas e químicas de um sedimento, analisáveis em escala microscópica, o qual se supõe ser produto de processos deposicionais e diagenéticos específicos.

Os critérios de individualização de petrofácies seguiram os seguintes aspectos, nesta ordem: 1) mineralogia e textura dos componentes deposicionais, 2) tipo de cimento dominante ou 3) porosidade dominante. Foram definidos dois grupos principais de petrofácies, quartzo-arenito (QA) e arenito feldspático (FA), subdivididos nos tipos 1 e 2 tendo em vista, respectivamente, a presença ou ausência de cutícula argilo-limonítica precoce. Os subtipos petrográficos são: poroso ( $p)$, com cimento carbonático (c), com cimento de felspato (f), com cimento 
silicoso (s), com cimento de betume (b) e com matriz infiltrada mecanicamente (i) (Quadro 5.2).

O critério de individualização das petrofácies seguiu a nomenclatura de rochas sedimentares de Dott (1964), a qual estipula o limite mínimo de $10 \%$ do conteúdo de feldspato no arcabouço para diferenciar os arenitos feldspáticos dos quartzosos.

Quadro 5.2 - Características da petrofácies das formações Pirambóia e Botucatu.

\begin{tabular}{|c|c|c|c|c|}
\hline $\begin{array}{c}\text { Petro- } \\
\text { fácies }\end{array}$ & $\begin{array}{c}\text { Comp. Mineraló- } \\
\text { gica do arcabouço }\end{array}$ & $\begin{array}{c}\text { Cutícula argilo- } \\
\text { ferruginosa }\end{array}$ & $\begin{array}{c}\text { Porosidade } \\
\text { dominante }\end{array}$ & Cimento dominante \\
\hline \multirow{2}{*}{$\mathrm{QA}$} & $\mathrm{F}<10 \%$ & $\mathrm{QA1}-$ presente & $\mathrm{QA1p}$ & $\begin{array}{c}\text { QA1c, QA1s, QA1f } \\
\text { QA2c, QA2s, QA2f }\end{array}$ \\
\cline { 3 - 4 } & $\mathrm{QA2}-$ tênue/ausente & QA2p & \multirow{2}{*}{ FA1c, FA1f, FA1i, FAb } \\
\multirow{2}{*}{$\mathrm{FA}$} & $\mathrm{F} \geq 10 \%$ & FA1 - presente & FA1p & FA2c \\
\cline { 3 - 4 } & & FA2 - tênue/ausente & FA2p & \\
\hline
\end{tabular}

As petrofácies reconhecidas em subsuperfície estão relacionadas na Tabela 5.2.

Tabela 5.2 - Relação de poços e petrofácies reconhecidas em subsuperfície.

\begin{tabular}{|c|c|c|c|c|}
\hline Localidade & Profundidade $(\mathrm{m})$ & I ntervalo estratigráfico & Petrofácies & Domínio genético \\
\hline Agudos & 178 & Formação Botucatu & QA1p & Fácies eólica \\
\hline \multirow[t]{2}{*}{ Araraquara (G5) } & 202 & Formação Botucatu & $\mathrm{QA1}(\mathrm{p})$ & Fácies eólica \\
\hline & 358 & Formação Pirambóia & $\mathrm{QA} 1(\mathrm{p}, \mathrm{c})$ & Fácies eólica \\
\hline Araraquara (F4) & 150,156 & Formação Botucatu & $\mathrm{QA1}(\mathrm{p})$ & Fácies eólica \\
\hline \multirow{3}{*}{$\begin{array}{l}\text { Araçatuba } \\
\text { (Petrobrás) }\end{array}$} & 1080,1116 & Formação Botucatu & QA1p & Fácies eólica \\
\hline & 1173 & Formação Pirambóia Superior & $\mathrm{QA} 2(\mathrm{p})$ & Fácies fluvial \\
\hline & $\begin{array}{l}1206,1233,1275 \\
1254,1302,1338 \\
1356,1374,1398\end{array}$ & Formação Pirambóia & FA1p & Fácies eólica \\
\hline $\begin{array}{l}\text { Araçatuba (D8, } \\
\text { 04-AR-01-SP) }\end{array}$ & 1158 & Formação Pirambóia Superior & QA2p, FA2c & Fácies flúvio-eólica \\
\hline \multirow[t]{3}{*}{$\begin{array}{c}\text { Barretos } \\
(04-\mathrm{BA}-03-\mathrm{SP})\end{array}$} & $\begin{array}{c}824,830,834,844, \\
846,852,876,880 \\
882,886,890\end{array}$ & Formação Botucatu & QA1p & Fácies eólica \\
\hline & $\begin{array}{l}900,904,906,908 \\
910,914,922,928 \\
\end{array}$ & Formação Pirambóia Superior & QA2C & Fácies flúvio-eólica \\
\hline & $\begin{array}{c}934,938,940,948 \\
952,954,958, \\
964,968,974,978, \\
982,986,990\end{array}$ & Formação Pirambóia & $\begin{array}{c}\text { QA1p, QA1c, } \\
\text { FA1p }\end{array}$ & Fácies eólica \\
\hline \multirow[t]{2}{*}{ Barretos (N1) } & $892,896,928,934$ & Formação Pirambóia & FA1p & Fácies eólica \\
\hline & 928,934 & Formação Pirambóia & FA1c & Fácies eólica \\
\hline Barrinha (L2) & $362,382,386,394$ & Formação Pirambóia Superior & QA2C & Fácies flúvio-eólica \\
\hline \multirow{2}{*}{$\begin{array}{c}\text { Batatais (04-BT- } \\
01-\mathrm{SP})\end{array}$} & 108,124 & Formação Botucatu & FA1p & Fácies eólica \\
\hline & $194,208,240$ & Formação Pirambóia & QA2p, QA1p & Fácies eólica \\
\hline \multirow[t]{2}{*}{ Batatais (T6) } & 326,330 & Formação Botucatu & QA1s & Fácies eólica \\
\hline & 496 & Formação Pirambóia & QA2C & Fácies eólica \\
\hline Bauru (B18) & $\begin{array}{c}62,68,70,72,74, \\
78\end{array}$ & Formação Botucatu & QA1C & Fácies eólica \\
\hline Bauru (H5) & 290 & Formação Pirambóia Superior & QA2C & Fácies flúvio-eólica \\
\hline
\end{tabular}




\begin{tabular}{|c|c|c|c|c|}
\hline Localidade & Profundidade (m) & I ntervalo estratigráfico & Petrofácies & Domínio genético \\
\hline \multirow{2}{*}{$\begin{array}{c}\text { Catanduva (H7, } \\
04-\mathrm{CT}-01-\mathrm{SP}))\end{array}$} & 476 & Formação Botucatu & $\mathrm{QA1}(\mathrm{p})$ & Fácies eólica \\
\hline & 668 & Formação Pirambóia Superior & $\mathrm{QA} 1(\mathrm{p}, \mathrm{c})$ & Fácies flúvio-eólica \\
\hline $\begin{array}{l}\text { Dois Córregos } \\
\text { (04-DC-01-SP) }\end{array}$ & 552 & Formação Pirambóia & QA1p & Fácies eólica \\
\hline $\begin{array}{l}\text { Fernandópolis } \\
(04-F E-03-S P)\end{array}$ & $\begin{array}{c}1502,1512,1528 \\
1590,1598\end{array}$ & Formação Pirambóia & FA1p, FA2p & Fácies eólica \\
\hline Ibaté (I1) & 234 & Formação Botucatu & $\mathrm{QA1}(\mathrm{p})$ & Fácies eólica \\
\hline \multirow{2}{*}{$\begin{array}{l}\text { Lagoa Azul } \\
\text { (Petrobrás) }\end{array}$} & $1284,1299,1317$ & Formação Botucatu & $\mathrm{QA1}(\mathrm{p})$ & Fácies eólica \\
\hline & 1335,1341 & Formação Pirambóia Superior & $\mathrm{QA} 2(\mathrm{p}, \mathrm{c})$ & Fácies fluvial \\
\hline \multirow[t]{2}{*}{ Lins (Petrobrás) } & $\mathrm{T} \# 4,750$ & Formação Botucatu & QA1p & Fácies eólica \\
\hline & $\mathrm{T} \# 6,949$ & Formação Pirambóia & FA1i & Fácies eólica \\
\hline Macatuba (B3) & $110,118,142,156$ & Formação Botucatu & QA1p & Fácies eólica \\
\hline \multirow[t]{2}{*}{ Matão (T5) } & $446,450,468$ & Formação Botucatu & QA2C & Fácies eólica \\
\hline & $474,492,508,520$ & Formação Pirambóia Superior & QA2f, QA2c & Fácies flúvio-eólica \\
\hline $\begin{array}{c}\text { Matão (04-MT- } \\
\text { 03-SP) }\end{array}$ & 428 & Formação Pirambóia Superior & QA2f, QA2C & Fácies flúvio-eólica \\
\hline $\begin{array}{c}\text { Olímpia } \\
\text { (Petrobrás) }\end{array}$ & $\mathrm{T \# 2,1031}$ & Formação Pirambóia & FA1i & Fácies eólica \\
\hline Orlândia (J9) & $320,380,450$ & Formação Pirambóia & FA1p, FA1c & Fácies eólica \\
\hline Pitangueiras (L3) & 672,682 & Formação Pirambóia & QA1p & Fácies eólica \\
\hline \multirow{3}{*}{$\begin{array}{l}\text { Presidente } \\
\text { Epitácio } \\
\text { (Petrobrás) }\end{array}$} & $\mathrm{T} \# 10,1625$ & Formação Botucatu & QA1p & Fácies eólica \\
\hline & 1732 & Formação Pirambóia Superior & FA2c & Fácies flúvio-eólica \\
\hline & 1813 & Formação Pirambóia & FA1i & Fácies eólica \\
\hline $\begin{array}{c}\text { Presidente } \\
\text { Prudente (A3, } \\
\text { 04-PP-01-SP) } \\
\end{array}$ & 1748,1780 & Formação Pirambóia & FA1p & Fácies eólica \\
\hline $\begin{array}{c}\text { Presidente } \\
\text { Prudente (04-PP- } \\
02-\mathrm{SP}) \\
\end{array}$ & $1684,1698,1702$ & Formação Pirambóia Superior & QA2c, QA2p & Fácies flúvio-eólica \\
\hline Santa Lúcia (L5) & 240,248 & Formação Botucatu & QA1p & Fácies eólica \\
\hline $\begin{array}{l}\text { Sta. Rosa do } \\
\text { Viterbo (A9) }\end{array}$ & 100 & Formação Pirambóia & FA1p & Fácies eólica \\
\hline São Carlos (CS) & $92,94,100,118$ & Formação Botucatu & QA1p & Fácies eólica \\
\hline $\begin{array}{c}\text { São Carlos (04- } \\
\text { SC-01-SP) }\end{array}$ & $198,232,234$ & Formação Botucatu & QA1p & Fácies eólica \\
\hline $\begin{array}{c}\text { S. J. do Rio Preto } \\
\text { (A1, 04-RP-01- } \\
\text { SP) }\end{array}$ & 1072 & Formação Pirambóia & FA1p & Fácies eólica \\
\hline \multirow{3}{*}{$\begin{array}{l}\text { S. J. do Rio Preto } \\
\text { (I4, 04-RP-03- } \\
\text { SP) }\end{array}$} & 848 & Formação Botucatu & $\mathrm{QA1}(\mathrm{p})$ & Fácies eólica \\
\hline & 1024 & Formação Pirambóia Superior & $\mathrm{QA} 1(\mathrm{p}, \mathrm{c})$ & Fácies flúvio-eólica \\
\hline & 1136 & Formação Pirambóia & $\mathrm{FA} 1(\mathrm{p}, \mathrm{c})$ & Fácies eólica \\
\hline $\begin{array}{c}\text { Sertãozinho (U5, } \\
\text { 04-SE-03-SP) }\end{array}$ & 304,316 & Formação Pirambóia Superior & QA2c, QA1p & Fácies flúvio-eólica \\
\hline $\begin{array}{c}\text { Sertãozinho (J11, } \\
04-\mathrm{SE}-01-\mathrm{SP})\end{array}$ & 376 & Formação Pirambóia & QA1p & Fácies eólica \\
\hline \multirow{2}{*}{$\begin{array}{l}\text { Votuporanga } \\
\text { (R5) }\end{array}$} & 1198 & Formação Botucatu & $\mathrm{QA1}(\mathrm{p})$ & Fácies eólica \\
\hline & 1316,1340 & Formação Pirambóia Superior & $\mathrm{QA} 2(\mathrm{p}, \mathrm{c})$ & Fácies flúvio-eólica \\
\hline
\end{tabular}




\section{Petrofácies QA1}

Componentes detríticos: Esta petrofácies apresenta granulometria modal e média na fração areia fina (125-250 $\mu \mathrm{m})$, com diâmetro dos grãos variando de 31 a $651 \mu \mathrm{m}$ (silte grosso a areia grossa). O arcabouço comumente apresenta granulometria bimodal (areia fina e média), às vezes unimodal (fração areia muito fina, fina ou média), sendo que a seleção por moda é sempre boa $(\sigma=0,35-0,50)$. Os grãos são bem arredondados a arredondados, na moda areia média, e subarredondados, ou até mesmo subangulares, na moda mais fina. O arcabouço é tipicamente frouxo, com índices de empacotamento geralmente entre 10 e 20\%, valor que pode alcançar $35 \%$ em profundidades maiores que $1500 \mathrm{~m}$, como no poço Presidente Epitácio. Nota-se orientação dos grãos alongados e é comum reconhecer segregação granular por variação granulométrica ou de empacotamento, com estratos de areia média com empacotamento mais frouxo que estratos de granulometria mais fina (Figura 5.8A). O conteúdo de feldspatos $(<10 \%)$, fragmentos líticos estáveis $(<5 \%)$ e instáveis $(<5 \%)$ é baixo, constituído, respectivamente, por: feldspato potássico, além de plagioclásio e pertita; quartzito e chert; mica grossa, mica-xisto e granitóide. Entre os minerais acessórios, reconheceram-se zircão, turmalina, rutilo, granada, epídoto, cianita e estaurolita. Na classificação de Folk (1968), esta petrofácies abrange tanto quartzo-arenitos quanto subarcóseos.

Componentes diagenéticos: O cimento eodiagenético presente em amostras de superfície ou subsuperfície corresponde a cutículas argilo-ferruginosas que envolvem quase toda a superfície dos grãos e ressaltam seu contorno. Na presença de cimentos sintaxiais, a cutícula de argila em lâmina, aparece na forma de "linhas de sujeira" (dust lines) (figura 5.8C). Sobre estas cutículas, foi reconhecida incipiente neoformação de argilominerais, com morfologia crenulada e composição química qualitativa (EDS) de $\mathrm{Si}, \mathrm{Al}, \mathrm{O}, \mathrm{Mg}$, $\mathrm{Ca}$ e $\mathrm{Fe}$, possivelmente relacionada a esmectita. As feições de compactação física e química são incipientes, tendo em vista as relações de contato entre grãos serem predominantemente do tipo pontuais e planares, sendo mais raros os contatos interpenetrativos (côncavoconvexo e suturado). Este último tipo é mais freqüente em profundidades abaixo de $800 \mathrm{~m}$, embora seja reconhecido mesmo em amostras de afloramento. 
QA1p: esta petrofácies designa arenitos com macroporosidade superior a 15\%, sendo que os valores variam de 16,6\% (poço de Presidente Epitácio) até 41\% (poço de Agudos). A porosidade secundária é principalmente alveolar em feldspato e, subordinadamente, móldica, sendo que este último tipo só foi observado em amostras de superfície ou em poços da zona de afloramentos. Os cimentos reconhecidos são sobrecrescimentos sintaxiais de quartzo (máximo de $11 \%$ da rocha) (figura $5.8 \mathrm{C}, \mathrm{E}, \mathrm{F}$ ) e de feldspato potássico (máximo de 1\%), além de argilominerais como substituição pseudomórfica de feldspato alcalino nos poços de Batatais e Presidente Epitácio.

QA1c: esta petrofácies, identificada apenas em amostras de subsuperfície, apresenta baixa porosidade (variável de 1,2\% a 11\%) devido à intensa cimentação intersticial por carbonato $(22,7 \%$ a 35,9\%) com textura espática e poiquilotópica (figura 5.8D). Avaliação sob MEV e catodoluminescência revelou ser este cimento essencialmente calcítico e sem zoneamentos composicionais.

QA1s: reconhecida em amostras de afloramento e em poços próximos à borda da bacia, esta petrofácies apresenta baixa porosidade $(0,7 \%$ e 2,5\%) e cimentação silicosa composta por franjas de opala poro-envolventes, de cerca de $20 \mu \mathrm{m}$ de espessura, e calcedônia fibrorradiada, formando mosaicos intersticiais, localmente de textura sacaroidal (chert). No poço de Batatais, as franjas de opala aparecem substituídas por calcedônia fibrorradiada à profundidade de $326 \mathrm{~m}$ (figura 5.8G). No poço de Bauru, aos $70 \mathrm{~m}$ de profundidade, estes cimentos silicosos encontram-se aparentemente substituídos por calcita micrítica (em franjas) e microespática (intersticial) (figura 5.8F). A substituição pseudomórfica da calcedônia pela calcita é sugestiva tendo em vista a preservação da forma original da franja e pelo fato de que a textura micrítica e microesparítica da calcita não foi reconhecida em nenhuma outra amostra analisada. 

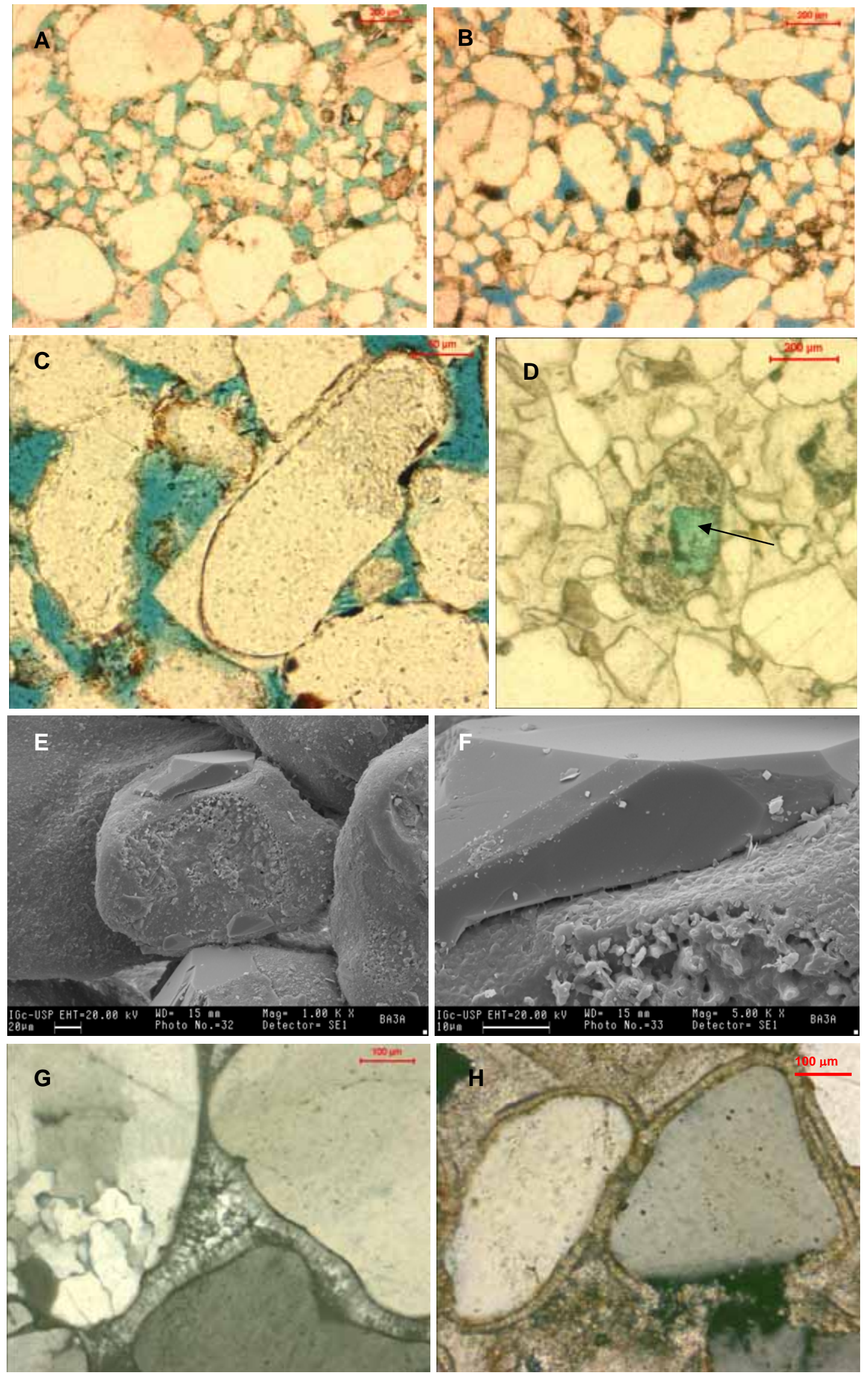

Figura 5.8 - Aspectos texturais e diagenéticos da petrofácies QA1. A) Feição de segregação granular por variação granulométrica (bimodalidade nas frações areia fina e média). Nicóis paralelos. Petrofácies QA1p, poço Barretos, $876 \mathrm{~m}$, fragmento de calha. B) Bimodalidade granulométrica, orientação e sutil imbricação dos grãos alongados. Notar empacotamento 
mais frouxo no estrato de areia média. Nicóis paralelos. Petrofácies QA1p, poço Araçatuba (Petrobrás), $1080 \mathrm{~m}$, fragmento de calha. C) Cutículas argilo-ferruginosas grão-envolventes precoces ressaltando contato entre quartzo detrítico e autígeno sintaxial. Nicóis paralelos. Petrofácies QA1p, poço Presidente Epitácio, 1625 m, testemunho. D) Porosidade secundária intragranular do tipo alveolar (seta) em feldspato potássico parcialmente alterado. Nicóis paralelos. Petrofácies QA1c, poço Matão, $450 \mathrm{~m}$, fragmento de calha. E) Imagem de MEV mostrando relação espacial entre cimento precoce (cutículas argilo-ferruginosas) e cimento de quartzo euédrico (terminações piramidais), este último sobrepondo o primeiro. Detector de elétrons secundários. Petrofácies QA1p, poço Barretos, $876 \mathrm{~m}$, fragmento de calha. F) Detalhe de imagem anterior, onde se pode notar a textura lisa das cutículas argiloferruginosas. G) Cimento de calcedônia fibrorradiada em franja poro-envolvente e de calcedônia criptocristalina intersticial que obstroem completamente a porosidade intergranular. Em amostras de superfície (Pedreira São Bento, figura 19), estas franjas são de composição opalina, o que demonstra que em profundidade houve substituição pseudomórfica por calcedônia. Nicóis cruzados. Petrofácies QA1s, poço Batatais, 326 m, fragmento de calha. H) Substituição pseudomórfica dos cimentos silicosos por calcita microespática (interstícios) e micrítica (franjas). O arcabouço nesta amostra é muito aberto, com predomínio de grãos "flutuantes". Nicóis cruzados. Poço Bauru, 70 m, fragmento de calha.

\section{Petrofácies QA2}

Componentes detríticos: Esta petrofácies é caracterizada por granulometria média nas frações areia fina (177-250 $\mu \mathrm{m})$ a areia média (250-350 $\mu \mathrm{m})$, apresentando variação no diâmetro dos grãos de 57 a $1680 \mu \mathrm{m}$ (silte grosso a areia muito grossa). O arcabouço apresenta granulometria unimodal ou bimodal (areia fina e areia média), sendo que a seleção de cada moda é moderada $(\sigma=0,50-1,0)$ a boa $(\sigma=0,35-0,50)$. Os grãos apresentam variedade no grau de arredondamento, desde angulares até arredondados, e as amostras com granulometria bimodal exibem grãos melhor arredondados. O arcabouço é aberto, com índice de empacotamento médio de $18 \%$. As feições de orientação dos grãos são nítidas e raramente se reconhece segregação granular. O conteúdo de feldspato varia de 2 a $9 \%$ (feldspato potássico, plagioclásio e pertita), o de fragmenos líticos estáveis de 1 a 4\% (predomínio de quartzito) e o de fragmentos líticos instáveis é normalmente $<1 \%$ (mica grossa e raros fragmentos de pelito). Minerais acessórios reconhecidos são: zircão, turmalina, rutilo, epídoto e estaurolita. Na classificação de Folk (1968), esta petrofácies insere-se preferencialmente no campo do quartzo-arenito.

Componentes diagenéticos: Foram reconhecidas cutículas argilo-ferruginosas grão-envolventes muito tênues, ou mesmo ausentes (figura 5.9A), além de sobrecrescimentos sintaxiais de quartzo (figura 5.9C, D) e de feldspato potássico (figura 5.9F). O cimento de quartzo (conteúdo de até $4 \%$ da rocha) foi identificado 
em poços de várias profundidades e em amostras de afloramento. No poço de Matão, o cimento de feldspato potássico chega a constituir $16 \%$ da rocha e envolve muitas vezes quase todo o contorno do grão detrítico, o que é indício de origem eodiagenética (figura 5.10). As feições de compactação física e química são incipientes, com predomínio de contatos intergranulares pontuais e planares, sendo menos comuns os côncavo-convexos.

QA2p: característica desta petrofácies é a porosidade alta, de cerca de $16 \%$ a $28 \%$, reconhecida preferencialmente em amostras de afloramento. A porosidade é principalmente intergranular e secundariamente intragranular alveolar (grãos de feldspato lixiviado).

QA2c: esta petrofácies apresenta baixa porosidade (2 a 10\%) devido à presença de cimento calcítico intersticial espático e poiquilotópico (figura 5.9E), o qual constitui de 19 a 36\% da rocha, e ocorre exclusivamente em amostras de subsuperfície. A porosidade secundária reconhecida é principalmente intraconstituinte, de dissolução de cimento carbonático, e alveolar em feldspato. Avaliação sob MEV e catodoluminescência revelou ser este cimento essencialmente calcítico e sem zoneamentos composicionais.

QA2f: esta petrofácies apresenta porosidade na faixa de 20 a $27 \%$ e intensa cimentação de feldspato potássico (adulária) eodiagenético (cerca de $8 \%$ da rocha, em média) na forma de franjas drusiformes, que envolvem o contorno dos grãos de composição silicosa (quartzo mono e policristalino), e de sobrecrescimentos sintaxiais ao redor de grãos detríticos (microclínio e ortoclásio) (figura 5.10). A textura drusiforme é conspícua nos fragmentos de granulometria areia grossa e desaparece nas porções de granulometria areia fina, sendo que nesta situação só se reconhecem os sobrecrescimentos sobre núcleos detríticos de feldspato. Cabe destacar o caráter excepcionalmente frouxo do arcabouço (índice de empacotamento de cerca de $10 \%$ ). 

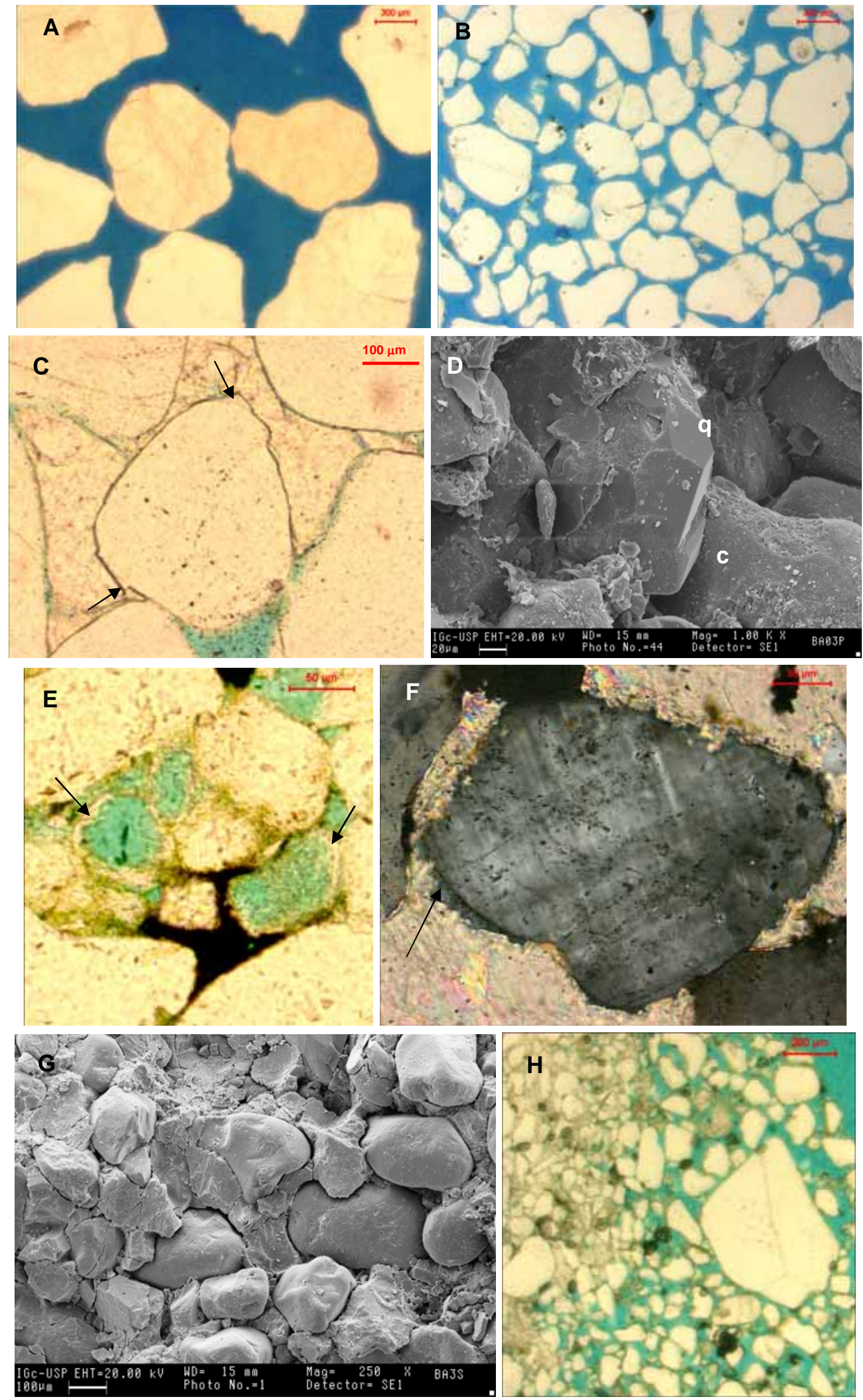

Figura 5.9 - Aspectos texturais e diagenéticos da petrofácies QA2. A) Grãos de quartzo ricos em inclusões alinhadas (tipo leitoso), de granulação areia grossa, subarredondados a subangulares, da petrofácies QA2(p). Notar ausência de cutículas argilo-ferruginosas. Nicóis 
paralelos, poço Lagoa Azul, $1341 \mathrm{~m}$, areia de calha. B) Arcabouço de granulometria bimodal (areia fina e areia média), cujos grãos não apresentam cutículas argilo-ferruginosas eodiagenéticas. Nicóis paralelos, petrofácies QA2(p), poço Catanduva, $668 \mathrm{~m}$, areia de calha. C) Cutículas argilo-ferruginosas grão-envolventes muito tênues, demarcando o sobrecrescimento de quartzo (seta) em grão detrítico arredondado. O espaço intergranular encontra-se parcialmente preenchido por calcita espática. Nicóis paralelos. Petrofácies QA2c, poço Barretos, $900 \mathrm{~m}$, fragmento de calha. D) Cimento de quartzo sintaxial (q). Notar tênue cutícula sobre grão detrítico (c). Imagem de MEV, detector de elétrons secundários, petrofácies QA2p, poço Barretos, $910 \mathrm{~m}$, fragmento de calha. E) Porosidade intragranular em grãos de feldspato potássico quase completamente lixiviados. Notar bordas dos grãos não alteradas (setas), as quais constituem cimento sintaxial precoce de maior estabilidade química devido à composição mais pura. Nicóis paralelos, petrofácies QA2p, poço Araçatuba, $1158 \mathrm{~m}$, fragmento de calha. F) Cimento de feldspato sintaxial (seta) sobre grão de microclínio fresco, envolvido por calcita poiquilotópica. Nicóis cruzados. Petrofácies QA2c, poço Barrinha, 394 m, fragmento de calha. G) Imagem de MEV ilustrando o aspecto compacto do sedimento devido à cimentação pervasiva de calcita intersticial. Detector de elétrons secundários. Petrofácies QA2c, poço Barretos, $922 \mathrm{~m}$, fragmento de calha. H) Arcabouço com granulação (silte grosso a areia média) e arredondamento variáveis (seleção pobre, $\sigma \sim 1,0$ ). Nicóis paralelos. Petrofácies QA2p, poço Sertãozinho, 316 $\mathrm{m}$, fragmento de calha.

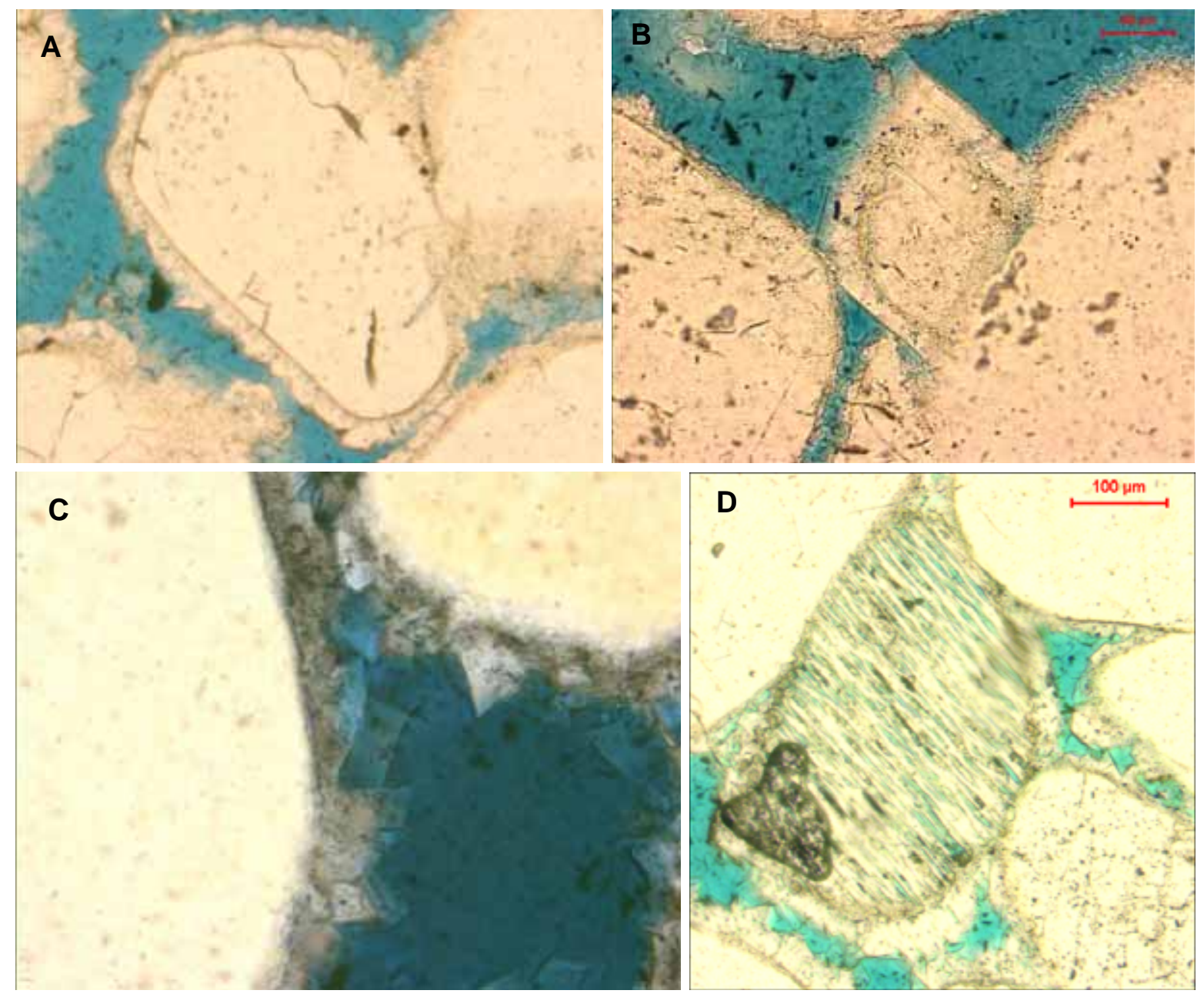

Figura 5.10 - Aspectos texturais e diagenéticos da petrofácies QA2f do poço Matão, profundidade de $508 \mathrm{~m}$. A) Franja drusiforme de feldspato potássico sobre grão de quartzo. B) Sobrecrescimento sintaxial ao redor de praticamente todo o contorno de grão de feldspato potássico. C) Detalhe da franja, evidenciando cristais romboédricos (adulária) de 
até $50 \mu \mathrm{m}$ de espessura. Nicóis cruzados. D) Porosidade intragranular em feldspato potássico. Notar que o sobrecrescimento feldspático sobre o grão não se encontra alterado.

\section{Petrofácies FA1}

Componentes detríticos: a granulometria média dos arenitos desta petrofácies varia de areia fina (177-250 $\mu \mathrm{m})$ a areia média $(250-500 \mu \mathrm{m})$, sendo que a bimodalidade nas frações areia fina e areia média ou areia fina e areia grossa é característica típica. O tamanho dos grãos varia de $53 \mu \mathrm{m}$ a $1022 \mu \mathrm{m}$ (silte grosso a areia muito grossa), sendo que a seleção por moda granulométrica é sempre boa $(\sigma=0,35-0,50)$. Os grãos apresentam grau de arredondamento variável, com predomínio de arredondado nas modas areia média e areia grossa e subarredondados a subangulares na moda areia fina. Feições de orientação e segregação granular são conspícuas. O arcabouço é aberto e os índices de proximidade de empacotamento variam de $15 \%$ a $38 \%$. O conteúdo de feldspato varia de 10 a 17\%, sendo constituído por feldspato potássico (microclínio e ortoclásio) e, secundariamente, por plagioclásio (em geral labradorita) e pertita. O conteúdo de clastos líticos estáveis (quartzito, chert e raros granitóides) varia de zero a $10 \%$ e o de líticos instáveis (micas grossa, pelito e xisto) é de no máximo $3 \%$. Os principais minerais acessórios são zircão, turmalina, rutilo, estaurolita, granada, epídoto, cianita e sillimanita. Na classificação de Folk (1968), esta petrofácies corresponde a subarcóseo ou sublitoarenito.

Componentes diagenéticos: foram reconhecidas cutículas argilo-ferruginosas grão-envolventes precoces, as quais constituem delgadas "linhas de sujeira" sob cimentos sintaxiais de quartzo ou feldspato (figura 5.11B). O cimento de feldspato $(0,4$ a $1 \%)$ é componente diagenético característico desta petrofácies e apresenta indícios de precipitação em condições eodiagenéticas. Constitui sobrecrescimento sintaxial e possui composição potássica. As feições de compactação mecânica e química são incipientes, exceto nos poços de Lins (949 m), Olímpia (1032 m), Fernandópolis $(1502 \mathrm{~m})$ e Presidente Prudente $(1780 \mathrm{~m})$, nos quais se reconhece presença de grãos de feldspato fraturados e de mica grossa e fragmentos pelíticos amassados (figura 5.11C). Nota-se, ainda, cimento de argilominerais como substituição pseudomórfica de grãos de feldspato alcalino (nos poços de Barretos, Batatais, Fernandópolis e Santa Rosa do Viterbo). No geral, os tipos de contato 
intergranular são predominantemente planares e pontuais, secundariamente côncavo-convexos e raramente suturados.

FA1p: esta petrofácies possui porosidade entre 17 e 24\%, sendo do tipo intergranular e intragranular alveolar e móldica (até 6\%) (figura 5.11G, H). Além dos cimentos eodiagenéticos já citados, destacam-se cutículas de argilominerais poro-envolventes, argila intersticial e cimento sintaxial de quartzo (traço a 2,7\%). Com relação aos argilominerais, a análise no sistema MEV-EDS revelou intensa autigênese sobre cutículas eodiagenéticas, com morfologia crenulada e composição química qualitativa de $\mathrm{Si}, \mathrm{Al}, \mathrm{O}, \mathrm{Mg}, \mathrm{Na}, \mathrm{Ca}$ e $\mathrm{Fe}$, indicativa de provável esmectita (figura $5.11 \mathrm{E}$ ). O cimento de quartzo sintaxial é posterior à fase de neoformação destes argilominerais, tendo em vista que as faces prismáticas de sobrecrescimento envolvem as bordas crenuladas do argilomineral (poço de Barretos, figura 5.11F). Em amostras de poço raso situado na zona de afloramento (Sta. Rosa do Viterbo, $100 \mathrm{~m}$ ), foram reconhecidos argilominerais autigênicos intersticiais, de hábito vermiforme, e em forma de franjas poro-envolventes, de composição qualitativa Si, $\mathrm{Al}, \mathrm{O}$, Fe e $\mathrm{K}$, que correspondem provavelmente a caulinita (figura $5.11 \mathrm{G}$ ).

FA1c: refere-se a arenitos com baixa porosidade (<8\%) e cimentação parcial de calcita espática e poiquilotópica intersticial (em média $23 \%$ da rocha).

FA1i: esta petrofácies foi definida em arenitos com argilas intersticiais (conteúdo de $9 \%$ no poço de Olímpia, 22\% no poço de Lins e $10 \%$ no poço de Presidente Epitácio) que obstroem parcialmente o espaço intergranular de arenitos com arcabouço de granulometria bimodal e seleção moderada. As características texturais destas argilas, as quais formam lamelas espessas ao redor dos grãos do arcabouço, bem como agregados maciços intersticiais, sugerem terem sido infiltradas mecanicamente em estágio eodiagenético (figura 5.11D), provavelmente sob condições freáticas (Moraes \& De Ros 1990). A macroporosidade é de $5 \%$ e de $17 \%$, respectivamente, nos poços de Olímpia e Lins, sendo do tipo intergranular e intraconstituinte (intragranular em feldspato alveolar e de contração). A presença de porosidade de contração nas argilas intersticiais indica redução de volume dos argilominerais ao longo da diagênese por perda de água estrutural. 

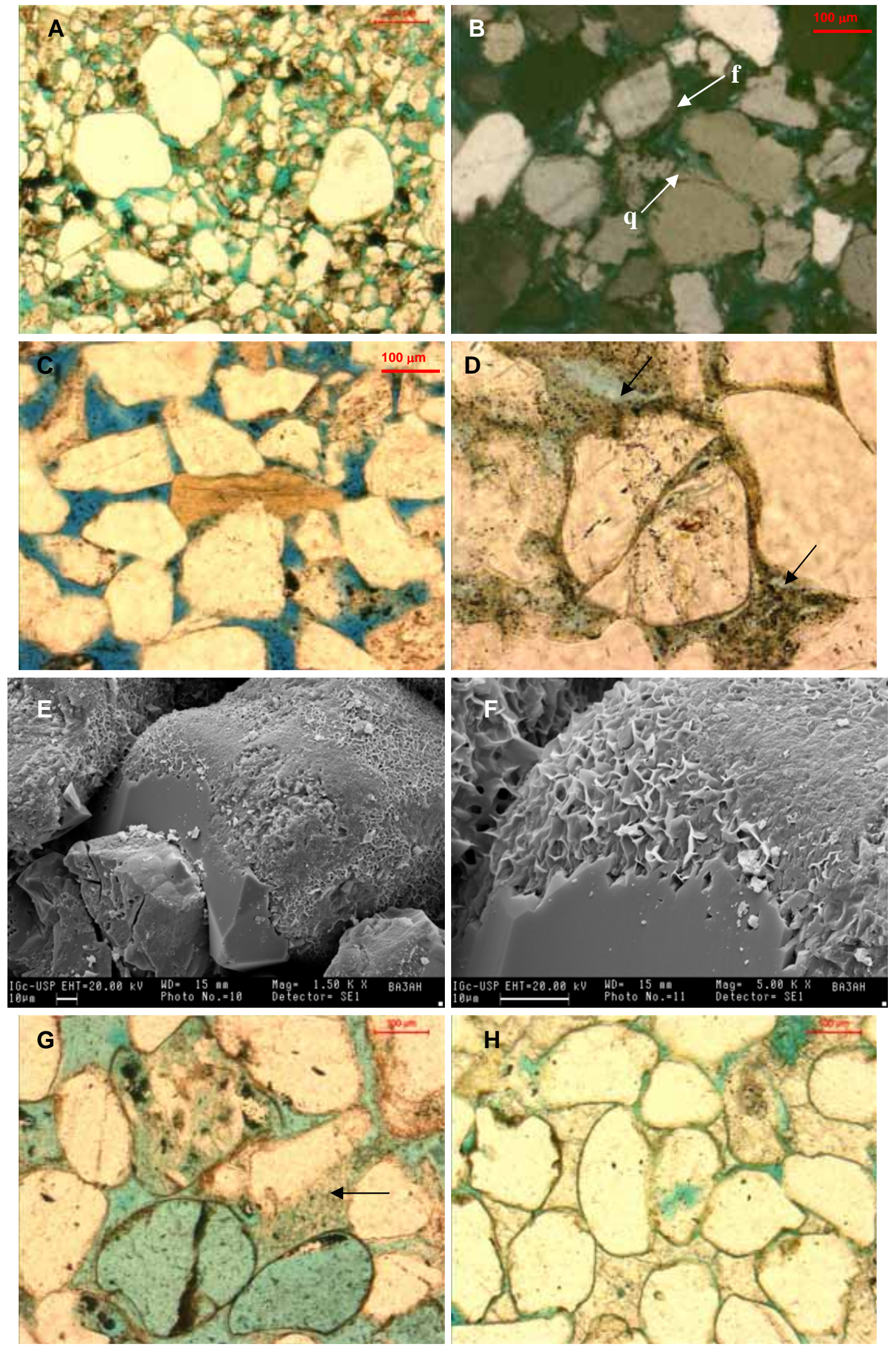

Figura 5.11 - Aspectos texturais e diagenéticos da petrofácies FA1. A) Aspecto geral dos arenitos bimodais (areia fina e média), com predomínio de grãos subarredondados e sem segregação granular. Nicóis paralelos. Petrofácies FA1p, poço Fernandópolis, $1512 \mathrm{~m}$, fragmento de calha. B) Cimento sintaxial de quartzo (q) e de feldspato (f) sobre cutícula argilo-ferruginosa ("linhas de sujeira"). Nicóis cruzados. Petrofácies FA1p, poço Barretos, 
$934 \mathrm{~m}$, fragmento de calha. C) Ligeiro amassamento de fragmento lítico de pelito (grão de tom mais alaranjado). Nicóis paralelos. Petrofácies FA1p, poço Lins, 949 m, testemunho 6. D) Grão de feldspato potássico fraturado pela compactação mecânica. A argila instersticial foi interpretada como eodiagenética, de infiltração mecânica. Notar porosidade de contração (seta) na argila intersticial. Nicóis paralelos. Petrofácies FA1i, poço Olímpia, $1031 \mathrm{~m}$, testemunho 2. E) Argilomineral autigênico de textura crenulada (provável esmectita) e sobrecrescimento de quartzo. A neoformação de argilomineral é aqui interpretada como regeneração de cutículas argilosas grão-envolventes eodiagenéticas. Imagem de MEV, detector de elétrons secundários. Petrofácies FA1p, poço Barretos, $990 \mathrm{~m}$, fragmento de calha. F) Detalhe da imagem anterior, mostrando as relações entre os cimentos. A neoformação de argilomineral ocorre sobre cutículas precoces e é envolvida, posteriormente, pelo cimento de quartzo. G) Porosidade intragranular em prováveis grãos de feldspato (poros móldicos no inferior da fotografia) e em fragmento lítico granitóide (porção superior). Notar cimento intersticial de argilominerais (seta), possivelmente caulinita. Nicóis paralelos. Petrofácies FA1p, poço Santa Rosa do Viterbo, $100 \mathrm{~m}$, fragmento de calha. H) Porosidade alveolar em grão de feldspato potássico. Nicóis paralelos. Petrofácies FA1c, poço Fernandópolis, 1528 m, fragmento de calha.

\section{Petrofácies FA2}

Componentes deposicionais: esta petrofácies apresenta granulometria modal e média na fração areia fina (125-250 $\mu \mathrm{m})$, com diâmetros de grãos variando de 63 $\mu \mathrm{m}$ a $497 \mu \mathrm{m}$ (areia muito fina a areia média). A distribuição granulométrica é unimodal, com seleção boa e moderada ( $\sigma$ entre 0,39 e 0,62). Os grãos do arcabouço possuem grau de arredondamento variável de subangular a arredondado. O empacotamento é tipicamente frouxo, com índices entre 10 e $20 \%$. O conteúdo de feldspato do arcabouço, constituído por feldspato potássico e plagioclásio, é de no máximo $11,4 \%$. É baixo também o conteúdo de fragmentos líticos estáveis $(<3 \%)$, formados por quartzito e chert, e instáveis $(<1 \%)$, incluindo mica grossa e pelito. Os minerais acessórios reconhecidos são zircão, turmalina, rutilo e granada. Na classificação de Folk (1968), esta petrofácies corresponde a subarcóseo.

Componentes diagenéticos: as cutículas argilo-ferruginosas grão-envolventes são muito tênues na petrofácies $F A 2$, o que dificulta a identificação das feições texturais originais dos grãos detríticos (figura 5.12). O conteúdo dos cimentos de quartzo e de feldspato é de no máximo 4,5\% e 0,4\%, respectivamente. As feições de compactação física são incipientes, assim como as de compactação química, com predomínio de contatos intergranulares planares e pontuais, ainda que localmente notem-se contatos do tipo suturado.

FA2p: esta petrofácies foi reconhecida no poço de Fernandópolis (profundidade de $1598 \mathrm{~m}$ ), próximo ao contato com os siltitos do Grupo Passa Dois. O cimento, quando presente, é na forma de sobrecrescimento de quartzo (figura 
5.12B). A porosidade total nesta profundidade é alta (27\%) e a porosidade secundária é do tipo alveolar (2,2\% da rocha).

FA2c: petrofácies caracterizada pela presença de cimento de calcita intersticial, a qual obstrói parcialmente o espaço intergranular diminuindo a porosidade para no máximo $17 \%$, além de cimentos de quartzo ( $2 \%$ ) e feldspato $(0,4 \%)$. Ocorre em profundidades abaixo de $1000 \mathrm{~m}$ nos poços de Presidente Epitácio (1732 m) e Araçatuba (1158 m).
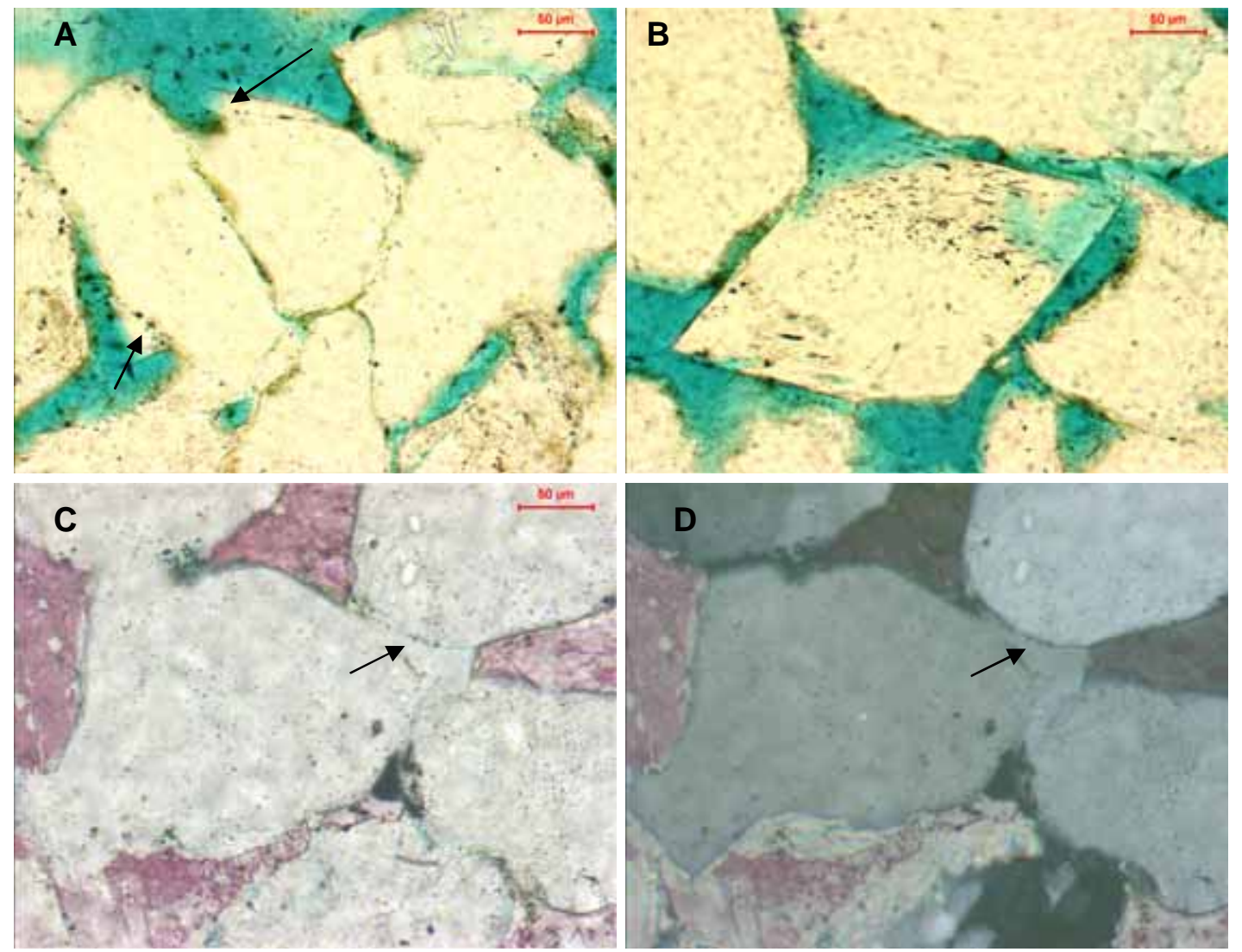

Figura 5.12 - Aspectos texturais e diagenéticos da petrofácies FA2. A) Cimento de quartzo sintaxial (setas) sobre grãos detríticos arredondados. Notar presença de tênues linhas de "sujeira". Nicóis paralelos. Petrofácies FA2p, poço Fernandópolis, 1598 m, fragmento de calha. B) Grão de feldspato potássico com cimento sintaxial, de hábito romboédrico, envolvendo todo o contorno do grão detrítico. Não se distingue a interface arcabouçocimento. Nicóis paralelos. Petrofácies FA2p, poço Fernandópolis, 1598 m, fragmento de calha. C) Cimento de quartzo sintaxial sobre tênue cutícula argilo-ferruginosa precoce (seta). Notar cimento de calcita intersticial (tingido de rosa). Nicóis paralelos. Petrofácies FA2c, poço Presidente Epitácio, 1732 m, fragmento de calha. D) Mesma imagem de C, a nicóis cruzados.

FAb: esta petrofácies foi identificada apenas em amostras da zona de afloramentos da Formação Pirambóia nas regiões de Angatuba, Anhembi, Bofete e 
Guareí (arenitos asfálticos). É constituída por arenitos muito finos a médios com cimento de betume (em média, $28,1 \%$ da rocha), o qual impregna cutículas argilosas poro-envolventes e preenche parte do espaço intergranular (figura 5.13). Este cimento é posterior aos cimentos sintaxiais de feldspato potássico (no máximo $1,7 \%$ ) e de quartzo (máximo de 0,7\%). Outros cimentos identificados são sulfeto (máximo de 1\%) e calcita espática (máximo de 22,3\%.) O empacotamento é aberto, com índices de proximidade de empacotamento entre $10 \%$ e $30 \%$. A macroporosidade total varia de $1 \%$ a $12 \%$ e a porosidade secundária é intragranular, do tipo alveolar (máximo de 0,7\%) e móldica (máximo de 0,5\%).
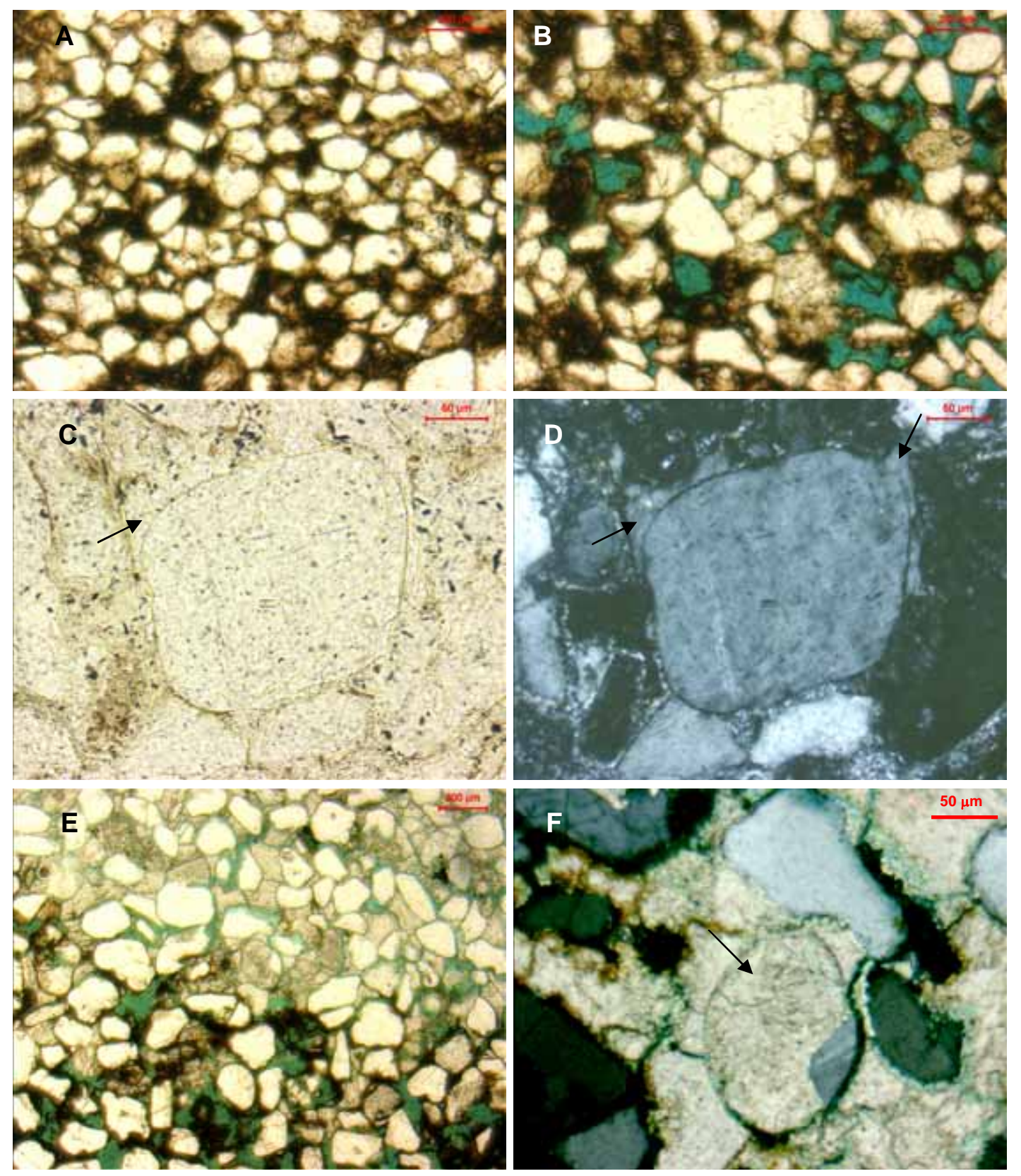

Figura 5.13 - Feições diagenéticas da petrofácies FAb. Cimento de betume obstruindo total (fotomicrografia A) e parcialmente (fotomicrografia $B$, porosidade da imagem 
aproximadamente 10\%) o espaço intergranular de arenitos finos de fácies eólica (duna). Nas fotomicrografias C e D, cimento sintaxial de feldspato potássico (setas). Cimento de calcita espática intersticial, aparentemente substituindo o cimento de betume na fotomicrografia $E$ (poção superior da imagem) e preenchendo porosidade intragranular (seta) na fotomicrografia F. Nicóis paralelos (exceto D e F). A, B, C, D: Amostra de afloramento, morro do Bofete, Rodovia SP280, km 174,5. E, F: Amostra de afloramento da Jazida Betumita, Anhembi, SP. 


\section{DIAGÊNESE}

Os estágios diagenéticos definidos por Choquette \& Pray (1970) e Schmidt \& McDonald (1979a) estão associados a alterações em condições de soterramento progressivo, desde raso (eodiagênese), envolvendo intervalo de profundidade sob influência das condições geoquímicas do ambiente sedimentar, até profundo (mesodiagênese), abaixo de $3000 \mathrm{~m}$. Além destes estágios, esses autores denominaram telodiagênese à retomada de condições de pequeno soterramento, por soerguimento tectônico no âmbito de um ciclo sedimentar completo. Morad et al. (2000) consideram que os limites aproximados de profundidade e de temperatura entre os estágios eo e mesodiagenético são, respectivamente, de 2000 $\mathrm{m}$ e $70^{\circ} \mathrm{C}$, condições que delimitariam grosso modo o início das principais transformações químicas minerais. Pelo fato da mesodiagênese envolver grande variedade de modificações ligadas a condições físico-químicas específicas, estes autores subdividiram-na em rasa (2 a $3 \mathrm{~km}$ de profundidade e temperaturas de 70 a $100^{\circ} \mathrm{C}$ ) e profunda (abaixo de $3 \mathrm{~km}$ e temperaturas maiores que $100^{\circ} \mathrm{C}$ ).

Os efeitos da diagênese sobre os componentes detríticos dos arenitos das formações Pirambóia e Botucatu na área de estudo referem-se a modificações ocorridas em profundidades relativamente rasas, de no máximo 2000 m, e temperaturas atuais de até $60^{\circ} \mathrm{C}$. Apesar das condições de soterramento raso, a evolução diagenética das duas unidades apresenta indícios de ter atravessado sucessão de estágios eo, meso e telodiagenético sensu Schmidt \& McDonald (1979a), tendo em vista a precipitação de cimentos precoces e tardios, a neoformação de argilominerais, as feições de compactação física e química incipientes e moderadas e a lixiviação de componentes quimicamente instáveis. Desta forma, admite-se aqui que as condições de soterramento mais profundo às quais as unidades Pirambóia e Botucatu foram submetidas referem-se ao limite mínimo do estágio mesodiagenético raso definido por Morad et al. (2000).

Nos arenitos das formações Pirambóia e Botucatu, foram identificados, como produtos da diagênese, cutículas argilo-ferruginosas, argilas mecanicamente infiltradas e precipitações autigênicas de feldspato, quartzo, argilominerais, calcita e analcima. 


\subsection{Processos e produtos diagenéticos}

Os principais componentes diagenéticos reconhecidos nessas duas formações encontram-se sintetizados em seguida.

\section{Cutícula argilo-ferruginosa}

As cutículas argilo-ferruginosas grão-envolventes constituem o cimento eodiagenético mais precoce, de ocorrência generalizada nos arenitos de fácies eólicas das formações Pirambóia e Botucatu (petrofácies FA1 e QA1). Estas cutículas caracterizam-se pela pequena espessura (1 a 5 micrômetros), pelo caráter em geral isópaco e pela cor alaranjada e textura sacaroidal ao microscópio petrográfico. Ressaltam o contorno do grão quando recoberto por cimentos sintaxiais de quartzo ou feldspato, o que fornece aspecto de "linhas de sujeira" (figura 6.1A). A avaliação das cutículas ao MEV revelou tratar-se de finas lamelas de aparência lisa, sendo que localmente pode-se reconhecer morfologia de placas anédricas assentadas concordantemente à superfície do grão, o que reforça a interpretação de origem mecânica. Esta morfologia denota formação sob condições de empacotamento de arcabouço frouxo, comumente encontradas próximas à superfície deposicional. Sobre estas cutículas, foi identificada neoformação de argilominerais em vários estágios, desde bordas sutilmente encurvadas até franjas com morfologia crenulada (figura 6.1C, D), interpretadas como regeneração dos argilominerais aderidos precocemente à superfície dos grãos.

A identificação dos argilominerais constituintes destas cutículas foi feita pela observação da morfologia dos cristálitos ao MEV, com auxílio da ferramenta de análise química qualitativa e semi-quantitativa (EDS). A identificação mais precisa dos argilominerais, através de difração de raios $X$ da fração argila, não foi possível de ser realizada tendo em vista o pequeno conteúdo do material de calha disponível para análise.

As cutículas argilo-ferruginosas da petrofácies QA1p (Formação Botucatu) possuem composição química qualitativa de $\mathrm{Si}, \mathrm{Al}, \mathrm{O}, \mathrm{Mg}, \mathrm{Fe}$, $\mathrm{Ca}$ e $\mathrm{K}$. Apesar das lamelas serem anédricas, situação que dificulta a identificação ao MEV, a composição química qualitativa é indicativa de esmectita. Mesmo na situação de soterramento profundo (>1500 m), como por exemplo no poço de Presidente Epitácio, a petrofácies QA1p apresenta incipiente neoformação de argilomineral sobre as cutículas precoces, com cristálitos de bordas encurvadas ou alongadas, orientadas ortogonalmente à superfície da cutícula. 

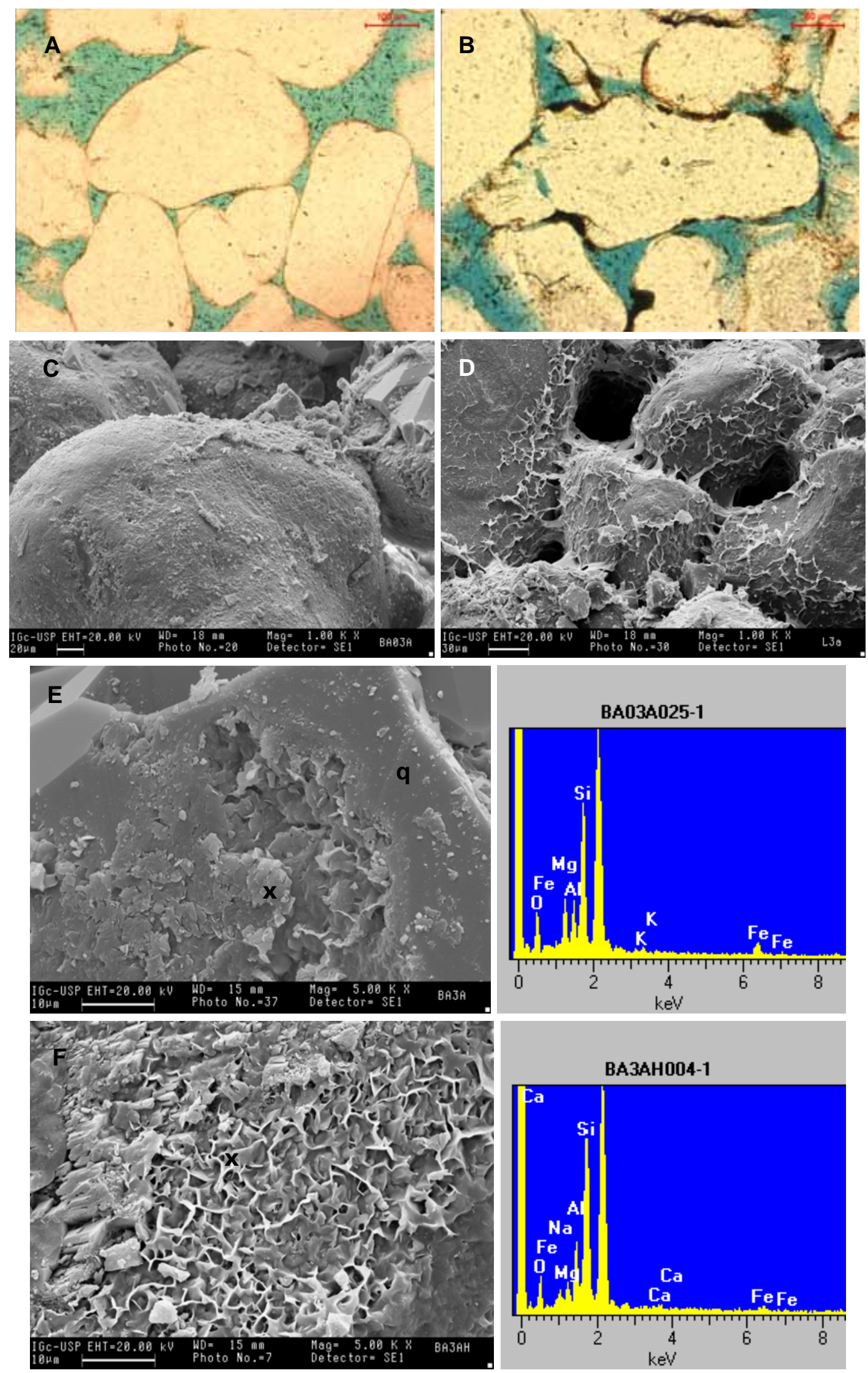

Figura 6.1 - Feições texturais das cutículas argilosas precoces. A) Cutículas argiloferruginosas precoces, as quais contornam os grãos exceto nos contatos intergranulares. Nicóis paralelos. Petrofácies QA1p, poço Barretos, $824 \mathrm{~m}$, fragmento de calha. B) Grão de quartzo policristalino com provável cutícula argilosa herdada, pois a mesma está presente inclusive nos contatos intergranulares e apresenta espessura irregular. Nicóis paralelos. 
Petrofácies QA1p, poço Presidente Epitácio, 1625 m, testemunho. C) Aspecto encurvado e sutilmente crenulado das lamelas da argila. Imagem MEV da mesma amostra da fotomicrografia A. D) Neoformação de argilomineral de hábito crenulado sobre cutículas grão-envolventes, formando pontes entre grãos e obstruindo parcialmente as gargantas de poro. Imagem de MEV, detector de elétrons secundários, petrofácies QA1p, poço Pitangueiras, $672 \mathrm{~m}$, fragmento de calha. E) Argilas anédricas, dispostas paralelamente à superfície do grão, de provável composição esmectítica (EDS qualitativo com Si, Al, O, Mg, Fe e K). Notar cimento de quartzo (q). Imagem MEV da mesma amostra da fotomicrografia A. F) Prováveis esmectitas autigênicas, de regeneração da cutícula aderida precocemente (EDS qualitativo com $\mathrm{Si}, \mathrm{Al}, \mathrm{O}, \mathrm{Mg}, \mathrm{Fe}, \mathrm{Ca}$ e $\mathrm{Na}$ ). Imagem de $\mathrm{MEV}$, detector de elétrons secundários, petrofácies FA1p, poço Barretos, 990 m, fragmento de calha.

As petrofácies porosas (QA1p, FA1p) da Formação Pirambóia, por sua vez, apresentam franja (até $5 \mu \mathrm{m}$ de espessura) de argilominerais de hábito crenulado sobre as cutículas argilo-ferruginosas precoces, típico de esmectitas autigênicas. A composição química qualitativa de $\mathrm{Si}, \mathrm{Al}, \mathrm{O}, \mathrm{Mg}, \mathrm{Fe}, \mathrm{Ca}$ e $\mathrm{Na}$ reforça esta interpretação.

Em arenitos eólicos, é relativamente comum a presença de cutículas argilosas herdadas (inherited clay rims), cuja correta identificação tem sido menosprezada, segundo Wilson (1992). As cutículas herdadas seriam parte do arcabouço reciclado, formadas previamente e fora do sítio de deposição, muito provavelmente pelos mecanismos descritos por Walker $(1967,1979)$ sobre a rubefação de sedimentos continentais. Os principais critérios de identificação das cutículas pré-deposicionais seriam sua espessura muito variável ao longo da superfície do grão (mais grossas nas irregularidades e depressões) e presença ao longo dos contatos intergranulares. No presente estudo, feições diagnósticas de cutículas herdadas foram observadas em arenitos da Formação Botucatu (petrofácies QA1p) no poço de Barretos, Lagoa Azul e Presidente Epitácio (figura 6.1B).

Walker (1967, 1979) associou o processo de rubefação de sedimentos continentais (red beds) à formação de cutículas geradas pela adesão de argilas dispersas no lençol freático à superfície dos grãos de areia, e pela precipitação in situ de hematita (pigmentação das cutículas) a partir de íons derivados da alteração de minerais ricos em ferro. O processo de introdução de argilas em depósitos arenosos aluviais e eólicos seria de natureza mecânica, basicamente pela infiltração de águas superficiais ao longo da zona vadosa e freática. Segundo Walker (1967, 1979), o tingimento diagenético dos arenitos processa-se in situ, em condições geoquímicas dentro do campo de estabilidade da hematita, ou seja, de águas intersticiais oxidantes e alcalinas. A formação de cutículas delgadas ao redor de 
grãos do arcabouço de arenitos eólicos está associada à pequena disponibilidade de finos e de água nestes ambientes sedimentares.

A autigênese da esmectita está associada a condições de intemperismo químico inibido, de baixa temperatura e de águas intersticiais alcalinas ricas em sílica e cátions dissolvidos, preferencialmente sob condições climáticas áridas. Estas características são compatíveis com aquelas reinantes nos cenários deposicionais das formações Pirambóia e Botucatu. McKinley et al. (2003) ressalta que as condições hidrodinâmicas do meio sedimentar podem influenciar a distribuição da esmectita, por exemplo, sendo mais rara em depósitos marinhos rasos (praiais e de maré) do que em depósitos aluviais e eólicos. Apesar dos depósitos eólicos e fluviais serem primordialmente de areias maturas em termos texturais (isentas de matriz), estes são mais sucetíveis à neoformação ou infiltração de argilas em condições eodiagenéticas devido a flutuações do lençol freático que ocorrem nos sistemas continentais.

Com o soterramento progressivo e conseqüente aumento de temperatura e evolução das características geoquímicas das águas intersticiais, a esmectita detrítica ou neoformada tende a se transformar em illita ou clorita (Bjørlykke \& Aagaard 1992) devido à perda de água interfoliar e incorporação ou substituição de cátions $\left(\mathrm{K}^{+}, \mathrm{Mg}^{+2}, \mathrm{Fe}^{+2}\right.$ e $\left.\mathrm{Al}^{+3}\right)$ na estrutura cristalina. Estas transformações químicas são fortementes dependentes da termodinâmica (temperaturas $>80^{\circ} \mathrm{C}$ ), cinética (tempo de reação rocha/água) e da disponibilidade de cátions dissolvidos, ou seja, dependem da alteração simultânea de outros minerais como feldspato e mica, e evoluem num primeiro estágio para interestratificados esmectita/illita ou esmectita/clorita (Bjørlykke \& Aagaard 1992, McKinley et al. 2003).

Ramos \& Formoso (1976) relatam o predomínio de montmorillonita (esmectita dioctaédrica) nos arenitos da Formação Botucatu lato sensu (inclui formações Pirambóia e Santa Maria), em amostras de testemunhos de sondagem de poços em SP, PR, SC e RS. Illita, clorita e camadas mistas são descritas nesse trabalho como de ocorrência subordinada, as duas primeiras identificadas em quantidades maiores que as de esmectita somente no poço de Olímpia (1362 m, Formação Pirambóia). Estes autores citam, ainda, a presença de caulinita no poço de Alegrete (RS), situado próximo à borda sul da bacia, em profundidades rasas, de até 250 m. Para França et al. (2003), as cutículas argilosas precoces da Formação Botucatu (lato sensu) são compostas apenas por illita com impregnação por óxido de ferro. 
A presença de camadas mistas esmectita/illita em arenitos porosos da Formação Pirambóia (petrofácies FA1p), nos poços de Fernandópolis e Presidente Prudente, a profundidades abaixo de 1000 m, é sugerida com base no hábito dos argilominerais neoformados encontrados, de bordas crenuladas com projeções ripiformes e encurvadas (figura 6.2) em direção ao centro do poro.
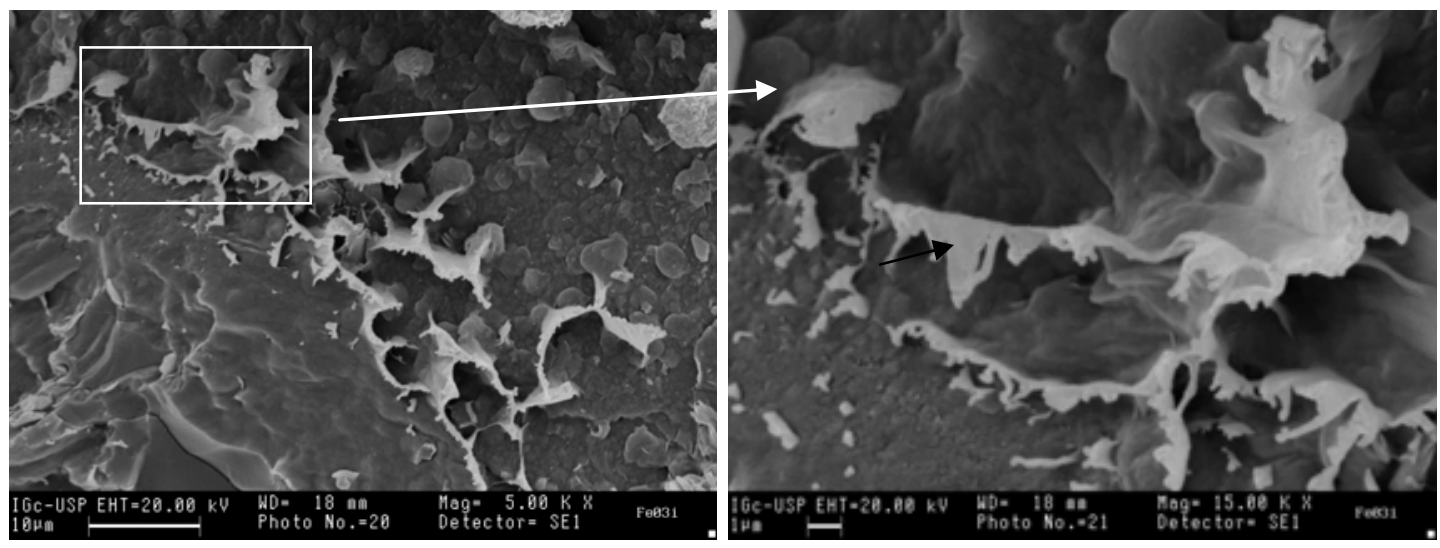

Figura 6.2 - Prováveis interestratificados esmectita/illita. Na imagem de detalhe à direita, notar que as bordas crenuladas do argilomineral autigênico apresentam projeções alongadas e em forma de fita (seta), muito sugestivo deste tipo de camada mista. A composição química qualititativa destes argilominerais é $\mathrm{Si}, \mathrm{Al}, \mathrm{O}, \mathrm{Mg}$, $\mathrm{Fe}$ e $\mathrm{K}$. Imagem de MEV, detector de elétrons secundários, petrofácies FA1p, poço Fernandópolis, 1524 m, fragmento de calha.

\section{Argila mecanicamente infiltrada}

Argilas infiltradas mecanicamente foram reconhecidas localmente em arenitos eólicos de interdunas da Formação Pirambóia (petrofácies FA1i) e em arenitos eólicos dunares da Formação Botucatu (petrofácies QA1p). Na petrofácies FA1i, o conteúdo destas argilas diagenéticas varia de $8,3 \%$ a $22 \%$. Elas ocorrem como cutículas anisópacas poro-envolventes (pore-lining) e agregados intersticiais obstruindo parcialmente o espaço intergranular (pore-filling). As argilas infiltradas da petrofácies QA1p ocorrem na forma de cristas e pontes, com lamelas dispostas ortogonalmente à superfície dos grãos (figura 6.3).

A infiltração mecânica de argila é comum em sistemas deposicionais aluviais desenvolvidos sob condições climáticas áridas, nos quais a posição profunda do nível freático permite a infiltração episódica de águas de enxurradas ricas em argila em suspensão, que promovem a introdução diagenética de finos nos horizontes arenosos isentos de matriz deposicional (Walker 1979). Segundo Moraes \& De Ros (1990, 1992), as concentrações de argila introduzida mecanicamente podem acontecer tanto na zona vadosa quanto na freática, embora esta última apresente 
maior potencial de preservação. As argilas infiltradas e depositadas na zona vadosa ocorrem quando o nível freático encontra-se muito profundo ou as enxurradas são de pequeno volume. Nesta situação, as argilas ficam retidas em filmes aquosos ao redor dos grãos, em meniscos e gotas pendulares. Já a concentração de argila no nível freático se dá pela diminuição da velocidade de fluxo das águas de infiltração ao encontrar a zona saturada, com conseqüente decantação das lamelas na superfície dos grãos (bordas dos poros). A zona de acumulação de argila infiltrada assim gerada adquire distribuição aproximadamente horizontal, no domínio superior da zona saturada (Moraes \& De Ros 1990). Este tipo de infiltração mecânica demonstra proximidade à superfície deposicional e é tipicamente eodiagenético, mas pode ocorrer também na telodiagênese.

Os principais critérios texturais de identificação das argilas infiltradas, descritos por Moraes \& De Ros (1990, 1992), são: a) presença de agregados e lamelas formando cristas e pontes ortogonais à superfície dos grãos e agregados pendulares geopetais, típicos de infiltração na zona vadosa; b) cutículas de espessura variável e cutans envolvendo os grãos do arcabouço e compostas por lamelas orientadas paralelamente à superfície aderida (zona freática); e c) agregados maciços intersticiais que obstroem parcial ou totalmente o espaço poroso, devido a condições de infiltração abundante de finos.

As características texturais das argilas infitradas reconhecidas nos arenitos das formações Pirambóia e Botucatu indicam que as condições de infiltração e decantação foram, respectivamente, na zona freática e na zona vadosa. Estas características são compatíveis com os modelos genéticos adotados para cada formação, ou seja, de maior presença de água nas depressões interdunas do sistema eólico úmido Pirambóia, como reflexo do nível freático relativamente elevado, em contraposição ao sistema eólico seco Botucatu, cuja posição do nível freático acredita-se tenha sido mais profunda. Na zona de afloramentos em São Paulo, foi reconhecido registro de enxurradas efêmeras nos domínios interdunas do sistema eólico Pirambóia (ver figura 4.5), cuja ocorrência é limitada ao domínio inferior do sistema.

Os argilominerais infiltrados são provavelmente de composição original esmectítica, conforme indicado pela composição química qualitativa dos argilominerais da petrofácies QA1p e FA1p no poço de Barretos, que é compatível com esmectita (EDS qualitativo de $\mathrm{Si}, \mathrm{Al}, \mathrm{O}, \mathrm{Mg}, \mathrm{Fe}, \mathrm{K} \pm \mathrm{Na}, \mathrm{Ca}$ ). No caso do poço de Olímpia, a presença de porosidade de contração na petrofácies FA1i (1032 m, 
Figura 6.3C) indica perda de água (desidratação) intercalada à estrutura de argilominerais de características expansíveis, os quais muito provavelmente passaram por processo de illitização ao longo da diagênese, conforme identificado em Ramos \& Formoso (1976).

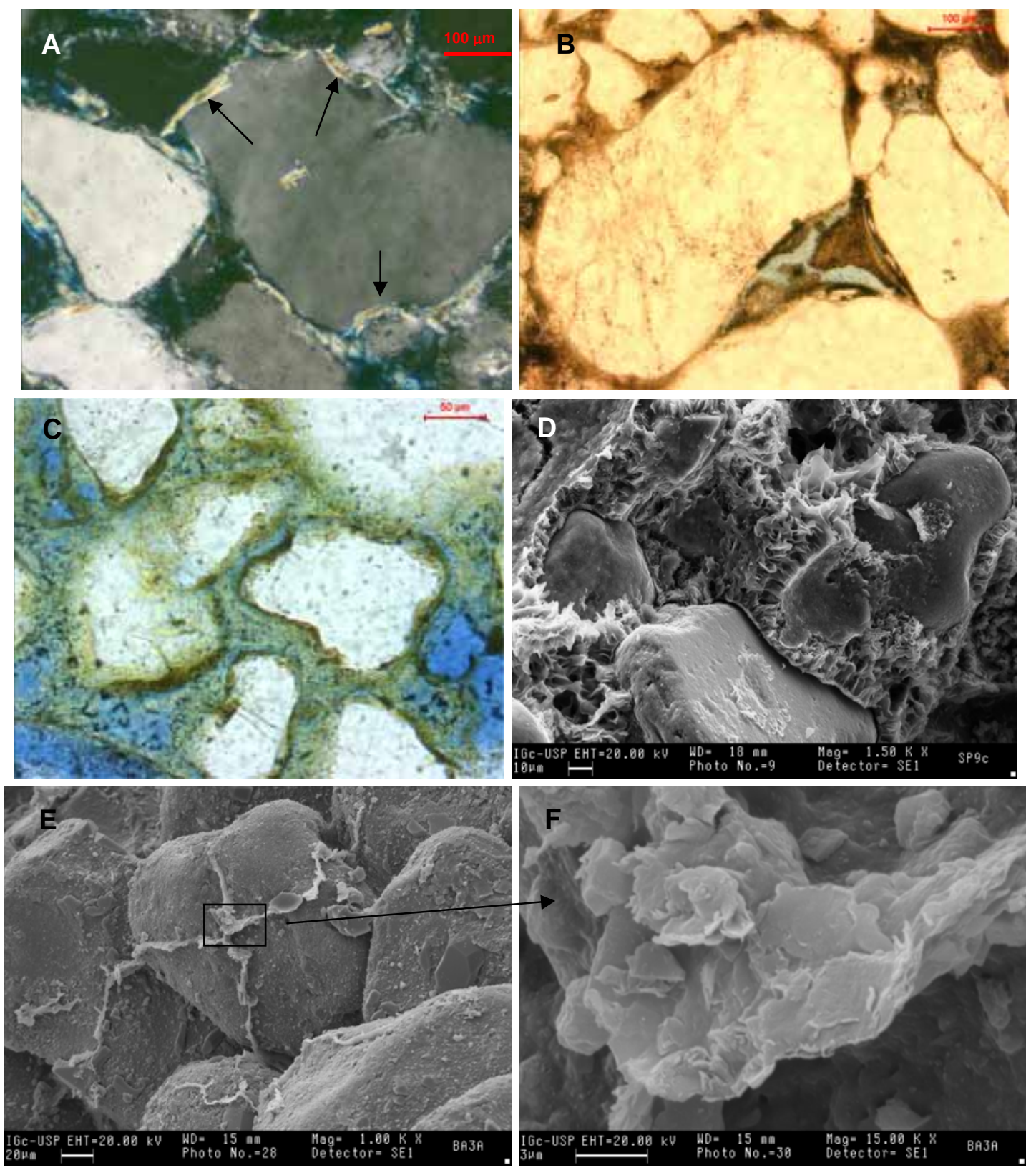

Figura 6.3 - Aspectos texturais das argilas mecanicamente infiltradas. A) Cutículas envoltórias de argilominerais de alta birrefringência (setas), com orientação ótica paralela à superfície dos grãos do arcabouço. Nicóis cruzados, petrofácies FA1i, poço Lins, 949 m, testemunho \#6. B) Argilas obstruindo totalmente o espaço intergranular. Notar porosidade de contração (desidratação) no centro da fotomicrografia. Nicóis paralelos, petrofácies FA1i, poço Olímpia, 1032m, testemunho \#2. C, D) Argilas infiltradas preenchendo parcialmente o espaço intergranular. Na imagem de MEV (D) é possível identificar regeneração do argilomineral (esmectita) e rearranjo dos cristálitos ortogonalmente à superfície do grão. Petrofácies FA1p, amostra de afloramento. E, F) Cristas e pontes de argilominerais infiltrados (provável esmectita), com orientação das lamelas ortogonalmente à superfície do grão (imagem de detalhe em F). Imagem de MEV, detector de elétrons secundários, petrofácies QA1p, poço Barretos, 824 m, fragmento de calha. 


\section{Feldspato autigênico}

Feldspato potássico autigênico, e, em menor proporção, albita, ocorrem heterogeneamente distribuídos nos arenitos das formações Pirambóia e Botucatu (máximo de 16\%), em praticamente todas as profundidades (figura 6.4). 0 cimento feldspático é constituinte característico e ocorre em maior quantidade nas petrofácies mais ricas em feldspato detrítico, com porcentagens de até 2,5\% nas petrofácies FA1 e FA2. Ocorre sob a forma de sobrecrescimento sintaxial grãoenvolvente em grãos de ortoclásio e microclínio, com lamelas sobrecrescidas predominantemente não geminadas, sendo não raro o hábito romboédrico (figura 6.5A). O aspecto contínuo deste cimento ao redor dos núcleos detríticos sugere precipitação eodiagenética, anterior à compactação.
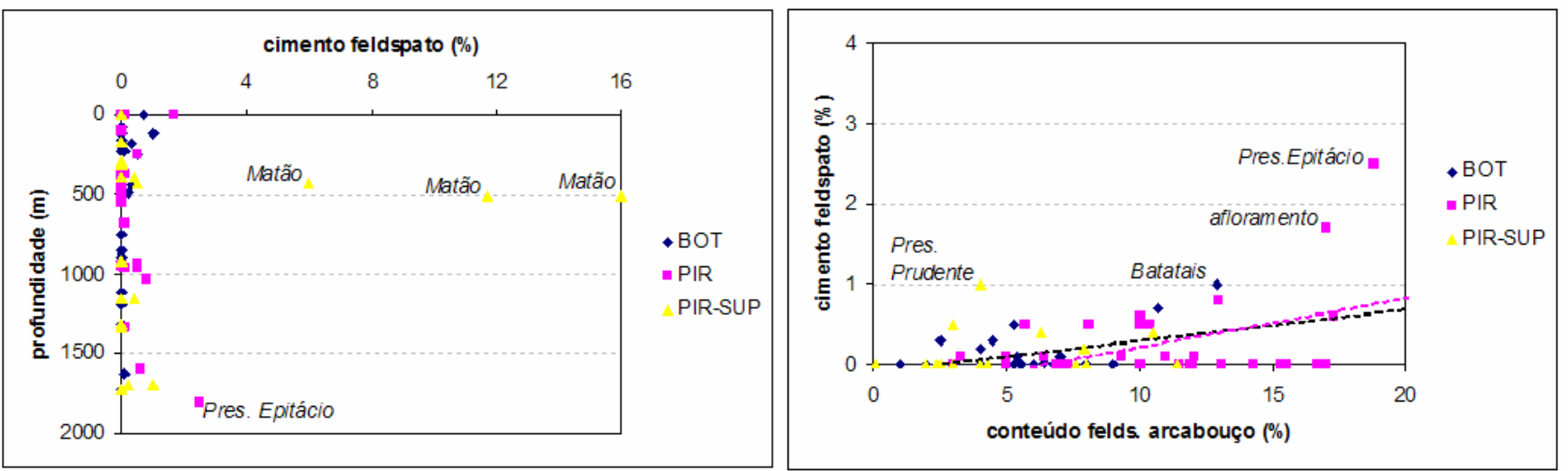

Figura 6.4 - Relação do conteúdo de cimento de feldspato com a profundidade e com o conteúdo de feldspato detrítico do arcabouço. Exceto o poço de Matão, cujos arenitos apresentam conteúdo anômalo de feldspato autígeno (petrofácies QA2f), este cimento representa no máximo $2,5 \%$ da rocha. O gráfico à direita evidencia tendência das petrofácies mais ricas em feldspato detrítico em apresentarem maior conteúdo de cimento do mesmo mineral, principalmente nos arenitos da Formação Pirambóia (coeficiente de correlação $c=0,45)$.

O cimento feldspático ocorre também na forma de franjas drusiformes ao redor de grãos de composição silicosa (quartzo e quartzito) e como cristais romboédricos intersticiais, ambos reconhecidos em arenitos da petrofácies QA2f, do poço de Matão (figura 6.5E). A franja apresenta cristais romboédricos alongados (hábito da adulária), com até $50 \mu \mathrm{m}$ de comprimento do eixo maior, os quais sobrepõem tênues cutículas argilo-ferruginosas precoces. 

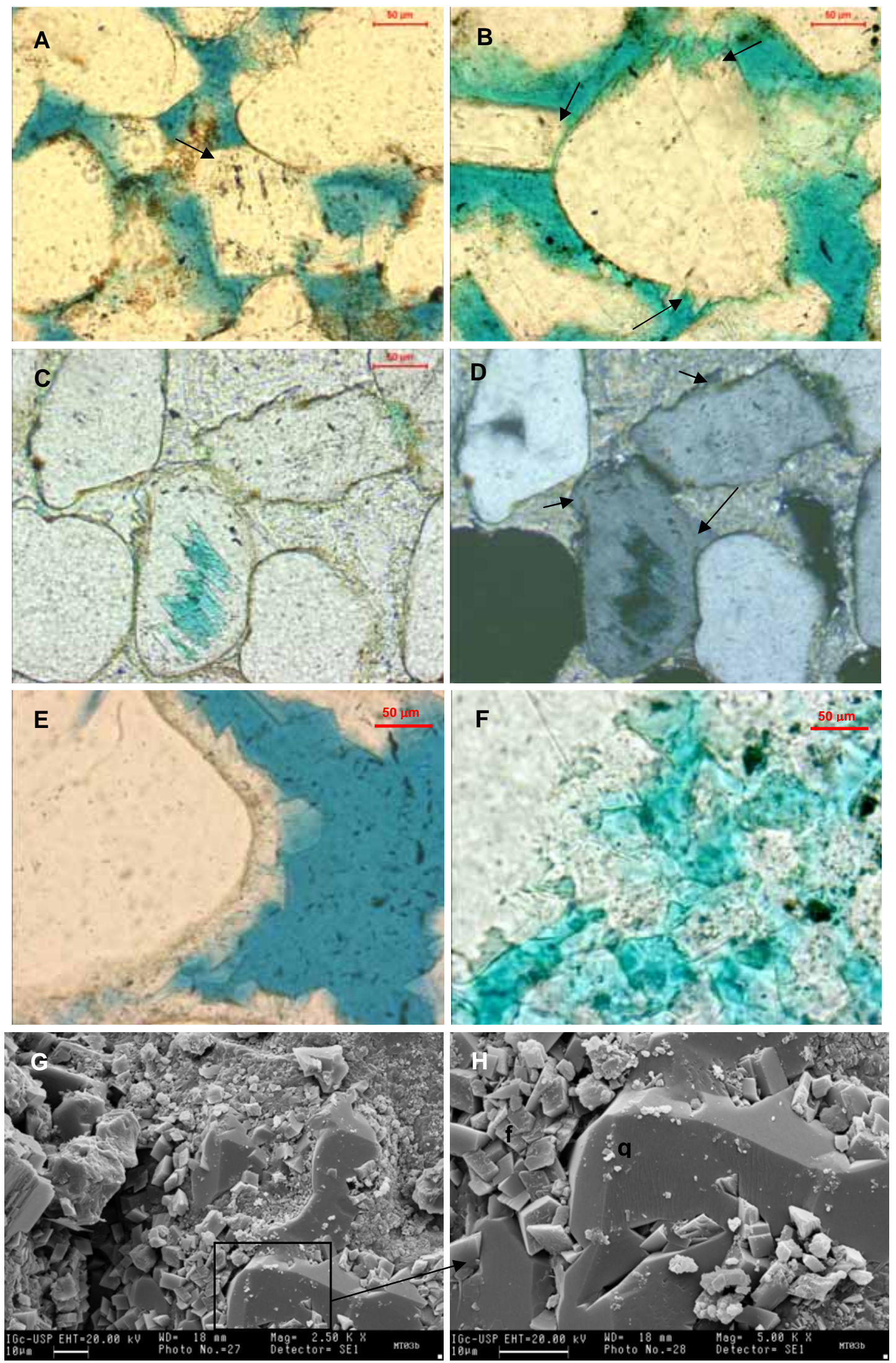

Figura 6.5 - Aspectos texturais dos cimentos de feldspato. O crescimento sintaxial de feldspato potássico ao redor de grãos de mesma composição ( $A$ a $D$ ), com faces euédricas sobrecrescidas (setas), é a textura mais comum nos arenitos estudados. Na petrofácies QA2f foi reconhecida cimentação por franjas de feldspato potássico de hábito romboédrico sobre grãos de quartzo (E) e como cimento intersticial (F). Nas imagens de $\operatorname{MEV}(G, H)$, 
pode-se observar que o cimento de quartzo (q) é posterior ao de feldspato (f), pois envolve os romboedros de adulária. A: petrofácies QA1p, poço Presidente Epitácio, $1625 \mathrm{~m}$, amostra de testemhunho; B: petrofácies FA1p, poço Fernandópolis, $1598 \mathrm{~m}$, fragmento de calha; C, D: petrofácies $F A 1 c$, poço Barretos, $968 \mathrm{~m}$, fragmento de calha. E a H: petrofácies QA2f, poço Matão, $428 \mathrm{~m}$, fragmento de calha.

A cimento de feldspato com textura drusiforme ocorre exclusivamente nos estratos de areia grossa, que apresentam grãos arredondados e com boa seleção. A origem eodiagenética deste cimento é atestada pelas relações espaciais do arcabouço, o qual é excepcionalmente aberto (IPKp $<10 \%$ ), com contatos intergranulares pontuais e grande quantidade de grãos flutuantes. A autigênese do feldspato tanto na forma de sobrecrescimento como na de franja deve ter sido contemporânea, conforme se pode deduzir pela presença de suturas medianas entre os dois tipos de cimento. A avaliação no sistema MEV-EDS revelou que a composição química semiquantitativa do cimento de feldspato é mais pura $(65,6 \%$ de $\mathrm{SiO}_{2}, 16,8 \%$ de $\mathrm{Al}_{2} \mathrm{O}_{3}, 17,1 \%$ de $\mathrm{K}_{2} \mathrm{O}$ e $0,5 \%$ de $\mathrm{Fe}_{2} \mathrm{O}_{3}$ ) se comparada à composição do grão $\left(65,3 \%\right.$ de $\mathrm{SiO}_{2}, 18,4 \%$ de $\mathrm{Al}_{2} \mathrm{O}_{3}, 15,1 \%$ de $\mathrm{K}_{2} \mathrm{O}, 0,7 \%$ de $\mathrm{NaO}$ e $0,5 \%$ de $\mathrm{BaO})$.

Cabe ressaltar a presença esporádica de cimento sintaxial de albita sobre grãos de plagioclásio, observada em amostras da Formação Botucatu (petrofácies QA1p) e Formação Pirambóia (petrofácies FA1i) nos poços de Barretos e Presidente Epitácio.

A presença de feldspato autigênico é bastante comum em arenitos feldspáticos de diversas profundidades, embora volumetricamente subordinada quando comparado a de outros cimentos, e tem sido associada à precipitação em condições eo ou mesodiagenéticas (McBride et al. 1987, Morad et al. 1990, 2000). O sobrecrescimento de feldspato potássico ou de albita sobre grãos detríticos de mesma composição (feldspato potássico e plagioclásio, respectivamente) consiste na textura mais comum deste tipo de cimento. Em grandes profundidades, abaixo de $3000 \mathrm{~m}$ e com temperaturas superiores a $100^{\circ} \mathrm{C}$, o feldspato potássico costuma ser substituído extensivamente pela albita, no processo conhecido como albitização (Morad et al. 1990). A precipitação destes cimentos está diretamente relacionada à reatividade dos sedimentos (composição feldspática) e à interação do arcabouço com as águas intersticiais alcalinas e saturadas em sílica. A paragênese mineral da rocha, com presença de argilominerais, carbonatos e sulfatos e as condições de temperatura do meio interferem nos tipos de reações envolvidas e subprodutos. 
Em condições superficiais, de pequeno soterramento e temperaturas abaixo de $70^{\circ} \mathrm{C}$ (eodiagênese), a precipitação de feldspato potássico depende diretamente do quimismo das águas intersticiais e do grau de saturação de íons K, Al e Si. Waugh (1978) ressalta que a autigênese de feldspato potássico inicia-se com a nucleação de pequenos cristais romboédricos (hábito da adulária), com mesma orientação ótica do grão hospedeiro, os quais coalescem até resultar nas faces planas. Sob condições de águas intersticiais com baixa saturação em íons, os cristais precipitam lentamente sobre os pontos de nucleação nos grãos hospedeiros, enquanto sob águas supersaturadas, com alta razão de fluxo iônico, ocorrem nucleações múltiplas e precipitação de cristais finos (De Ros et al. 1994).

São poucos os relatos sobre autigênese precoce de feldspato potássico em arenitos, mas merecem destaque os trabalhos focados nos reservatórios aluviais da Bacia Potiguar (Pereira 1991, Anjos et al. 2000 e Maraschin et al. 2004). Maraschin et al. (2004) descrevem sobrecrescimentos de composição potássica pura (adulária) em arenitos da Formação Açu, supostamente precipitados a partir de águas meteóricas enriquecidas em álcalis, sob condição climática semi-árida a úmida. Este cenário teria favorecido a neoformação de feldspato através da contínua infiltração de águas ricas em $\mathrm{K}, \mathrm{Al}$ e $\mathrm{Si}$, derivadas da alteração de minerais micáceos e de feldspatos, contidos nas rochas das margens da bacia.

No caso dos cimentos de feldspato aqui reconhecidos, além dos sobrecrescimentos, nota-se precipitação de franjas drusiformes ao redor de grãos não feldspáticos. Este aspecto revela supersaturação em álcalis e sílica das águas intersticiais, porosidade primária alta, tempo relativamente longo de reação entre rocha e fluido e condições relativamente estagnantes das águas intersticiais. Estas variáveis estão de acordo com as condições climáticas áridas inferidas para a sedimentação Botucatu e Pirambóia.

A autigênese precoce de feldspato potássico tem sido atribuída a condições climáticas semi-áridas a subúmidas e mínimo intemperismo químico de rochas ricas em micas e outros minerais potássicos (por exemplo, rochas metamórficas e vulcânicas) para suprir as águas intersticiais com K, Al e Si dissolvidos. Sob estas condições, a saturação de íons $\mathrm{K}$ nas águas é alcançada mesmo com a dissolução de quantidades muito pequenas de minerais-fontes deste íon (Maraschin et al. 2004). 
Acredita-se que as interdunas do sistema eólico úmido Pirambóia tenham sido caracterizados, pelo menos localmente, por condições de supersaturação de íons (águas alcalinas) devido à associação lateral com o sistema marinho Corumbataí/Teresina, o qual deve ter exercido controle sobre as flutuações do nível freático deste sistema eólico (Giannini 2001). Desta forma, a precipitação eodiagenética de feldspato potássico seria favorecida nas condições subaflorantes das interdunas costeiras. Adicionalmente, pode-se aventar ainda que uma fonte hidrotermal tenha promovido extensiva precipitação deste tipo de cimento no final da deposição da Formação Pirambóia. Existem evidências de eventos hidrotermais (vents) na Formação Teresina, descritos por Yamamoto et al. (2005).

Com relação à Formação Botucatu, a associação com as rochas vulcânicas da Formação Serra Geral, as quais interdigitam e soterram as dunas do sistema eólico seco, pode representar uma fonte adicional de álcalis e sílica dissolvida nas águas intersticiais eodiagenéticas daquela unidade, o que teria favorecido a precipitação de cimento de feldspato.

\section{Quartzo autigênico}

À semelhança do feldspato autigênico, o cimento de quartzo apresenta distribuição heterogênea nos arenitos estudados, porém em ocorrência volumetricamente mais expressiva, de até $5,8 \%$ da rocha. Caracteriza-se por sobrecrescimentos sintaxiais, formados por faces retilíneas e euédricas (terminações piramidais), as quais sobrepõem as cutículas argilo-ferruginosas precoces e envolvem bordas crenuladas de argilomineral neoformado (esmectita), sendo portanto a ele posteriores. Nas petrofácies cujas cutículas precoces são muito tênues ou ausentes (QA2), o cimento de quartzo cobre boa parte da superfície dos grãos detríticos o que, à primeira vista, sugere neoformação em condições anteriores ou contemporâneas à compactação química. Em amostras de granulometria média e grossa desta petrofácies, a identificação de cimento de quartzo é dificultada pelo caráter tênue, indistinto ou descontínuo da "linha de sujeira" no contorno do grão; no entanto, grãos de quartzo com faces aparentes retilíneas, formas exóticas (apófises) ou interligados por meniscos são sugestivos da presença deste tipo de cimento. A avaliação sob microscópio com catodoluminescência mostrou que os cimentos sintaxiais não são luminescentes. 
Os conteúdos máximos de cimento de quartzo nos arenitos da Formação Botucatu foram medidos no poço de Presidente Epitácio (5,8\% da rocha, $1625 \mathrm{~m}$ de profundidade) e Batatais (11\%, $330 \mathrm{~m}$ de profundidade), sendo que no primeiro poço o quartzo autigênico é nitidamente pós-compactação física e química. Os arenitos da Formação Pirambóia apresentam conteúdo máximo deste cimento em profundidades abaixo de $1500 \mathrm{~m}$, no poço de Fernandópolis (4,5\% da rocha, fácies eólica) e Presidente Prudente (4\% da rocha, fácies flúvio-eólica). Existe, portanto, uma tendência nítida de aumento do conteúdo de cimento de quartzo com o aumento da profundidade nas duas unidades (figura 6.6). A presença de cutículas e franjas argilosas ao redor dos grãos do arcabouço parece constituir uma barreira significativa à precipitação de quartzo autigênico (figura 6.7). Por outro lado, nas petrofácies cujo arcabouço é envolvido apenas por tênues cutículas argilosas precoces (QA2), há evidencias de que a autigênese do quartzo teria começado já na eodiagênese e uma das razões para isto seria a ausência de barreiras eficientes à nucleação deste cimento, conforme apontado por Pittman et al. (1992).
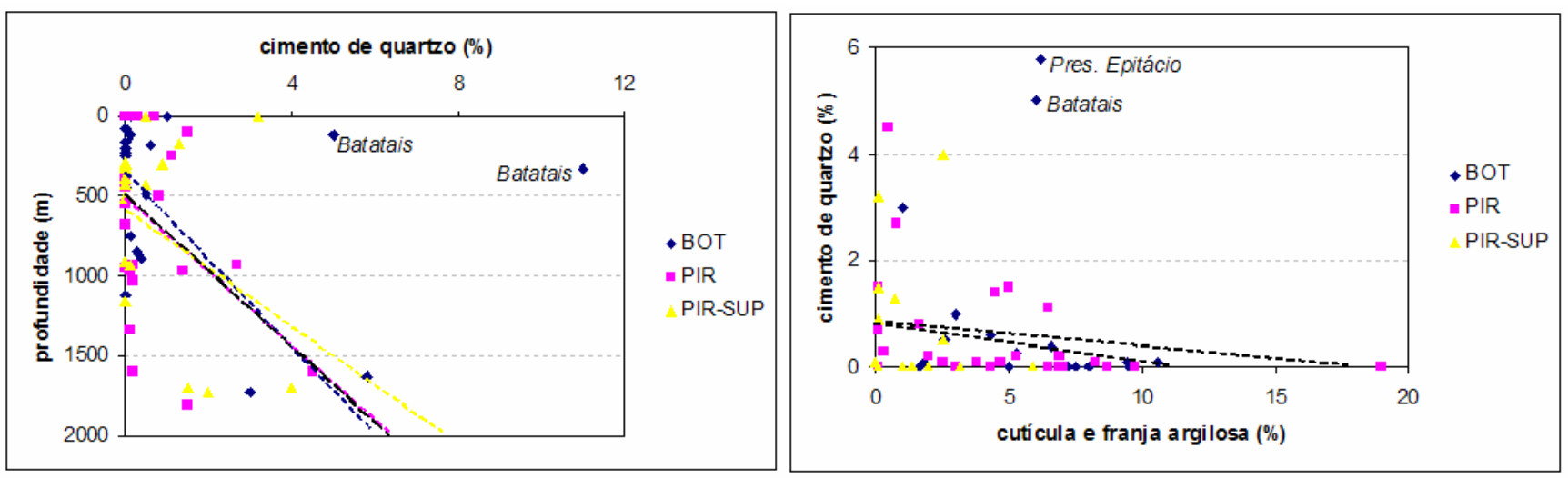

Figura 6.6 - Distribuição do cimento de quartzo com a profundidade e sua relação com as cutículas argilo-ferruginosas precoces. No gráfico da esquerda, nota-se tendência de aumento do conteúdo do cimento com a profundidade, indicando possivelmente sua origem mesodiagenética, à exceção dos arenitos do poço de Batatais. No gráfico da direita, podese inferir, em termos gerais, que a presença de cutículas argilosas envoltórias aos grãos é um elemento inibidor da precipitação de cimento de quartzo. 


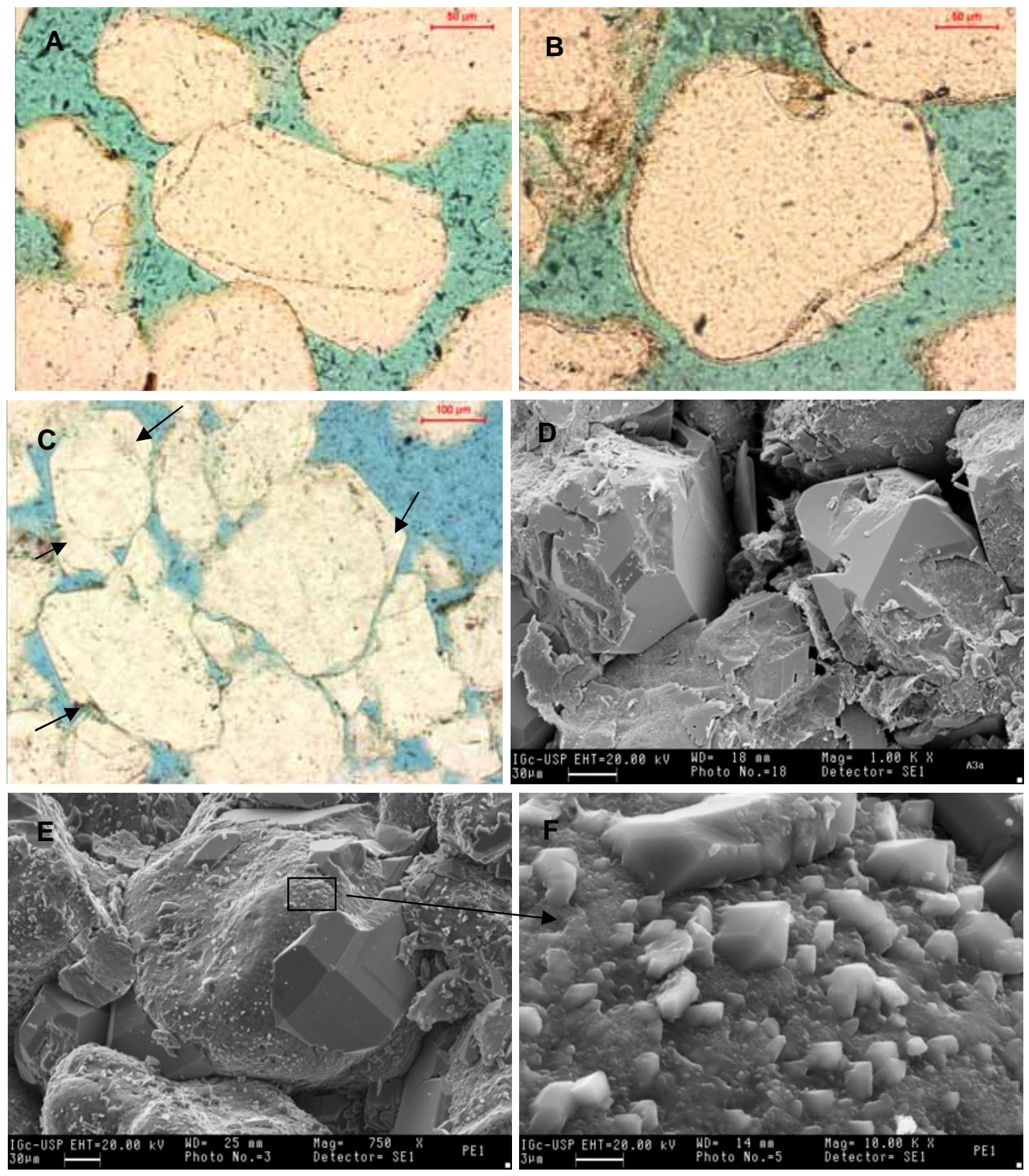

Figura 6.7 - Feições texturais do cimento de quartzo (setas), o qual ocorre como crescimento secundário sintaxial, envolvendo parcial a totalmente os grãos de quartzo do arcabouço ( $\mathrm{A}$ a $\mathrm{C}$ ). O hábito dos cristais em geral é euédrico, com terminações piramidais $(D, E)$ bem desenvolvidas ou múltiplos pontos de nucleação (detalhe na imagem $F$ ). A: petrofácies QA1p, poço Barretos, $824 \mathrm{~m}$. B: petrofácies FA1p, poço Santa Rosa do Viterbo, 100 m. C: petrofácies QA2p, poço Presidente Epitácio, 1732 m. D: imagem de MEV, petrofácies FA1p, poço Presidente Prudente, $1748 \mathrm{~m}$. E, F: imagem de MEV, petrofácies QA1p, poço Presidente Epitácio, 1625, amostra de testemunho.

McBride (1989) considera o sobrecrescimento (overgrowth) de quartzo sintaxial como a textura mais comum do quartzo diagenético em arenitos. Segundo este autor, o crescimento secundário inicia-se com a coalescência e fusão de vários pequenos cristais sobre o grão hospedeiro, até formar as faces euédricas, de hábito piramidal (overgrowth), ou pelo desenvolvimento dominante de um dos cristais, 
adquirindo hábito prismático alongado (outgrowth). Existe certa controvérsia sobre a seletividade granulométrica da cimentação de quartzo em arenitos, ou seja, se este cimento precipita em maior quantidade em horizontes arenosos finos ou grossos. McBride (1989) aponta que apesar de trabalhos experimentais apontarem que a cimentação é mais eficiente em estratos de areia fina, os estratos de granulação grossa, mais permeáveis, permitem altas razões de circulação de fluidos intersticiais e, portanto, tornam-se cimentados mais rapidamente que os estratos arenosos finos.

A correlação positiva entre volume de cimento de quartzo e profundidade está diretamente ligada ao aumento da temperatura com o soterramento progressivo, fator que interfere no equilíbrio termodinâmico de vários minerais silicáticos. Em condições de soterramento raso (até $3000 \mathrm{~m}$ ), as principais alterações mesodiagenéticas nos sedimentos, e especialmente a cimentação de quartzo, ocorreriam dentro do intervalo de temperatura entre $70^{\circ}$ e $100^{\circ} \mathrm{C}$ (Morad et al. 2000).

As principais variáveis de controle da precipitação de quartzo na diagênese são temperatura e disponibilidade de sílica dissolvida, sendo que a cimentação parece ser favorecida sob condições de águas salinas, alto pH e baixa concentração de potássio (Worden \& Morad 2000).

Várias fontes responsáveis pelo enriquecimento de sílica na água intersticial têm sido propostas (McBride 1989) e de fato mais de uma fonte pode ser responsável pela cimentação de quartzo, principalmente: a) dissolução por pressão ao longo dos contatos entre grãos de composição silicática (contatos interpenetrativos e estilólitos) e reprecipitação local na forma de cimento; b) dissolução de sílica amorfa, principalmente fragmentos vulcânicos e biogênicos; c) transformação de esmectita em illita ou clorita, cujas reações resultam em excesso de sílica dissolvida; d) alteração de feldspatos detríticos e substituição pseudomórfica por caulinita, illita ou albita; e) substituição de minerais silicáticos por carbonato. Em a) e b) o processo de dissolução e reprecipitação de sílica é termodinamicamente controlado. Em c) e d), as transformações minerais envolvidas, que resultam em excesso de sílica dissolvida, dependem também da composição química das águas intersticiais.

No caso dos arenitos das formações Pirambóia e Botucatu, a cimentação de quartzo é posterior à neoformação de argilominerais das cutículas envoltórias aos 
grãos e ao cimento de feldspato, tendo em vista que os sobrecrescimentos de quartzo envolvem os outros cimentos (ver figura $5.11 \mathrm{~F}$ e 6.5H). Apesar das condições de soterramento relativamente raso das unidades, a cimentação é volumetricamente significativa em profundidades abaixo de $1500 \mathrm{~m}$, o que aponta para possível origem mesodiagenética do cimento de quartzo. Exceção encontra-se na petrofácies QA2, cujo início da precipitação de quartzo diagenético parece ter ocorrido mais precocemente, devido às características frouxas do arcabouço (ver figura 5.5). A petrofácies QA1s do poço de Batatais representa uma situação anômala, na qual o cimento de quartzo está associado a processo de silicificação de arenitos em condições de proximidade à borda da bacia, aspecto que será abordado adiante (item Sílica de baixa cristalinidade).

\section{Argilominerais}

Grãos de feldspato potássico (preferencialmente ortoclásio), e, em menor proporção, de mica e plagioclásio, ocorrem substituídos parcialmente por argilominerais (até $1 \%$ da rocha), os quais constituem finas lamelas de alta birrefringência. Estas lamelas chegam a camuflar as feições ópticas originais do mineral, conferindo aspecto "sujo" ao grão (ou "sericitizado", figura 6.8A). Embora tenha sido reconhecida em todas as petrofácies, a substituição por argilominerais é típica das amostras de afloramento ou de poços rasos subaflorantes e, nesta situação, sua origem é intempérica. Por outro lado, em poços profundos como Presidente Epitácio, Presidente Prudente, Lins, Fernandópolis e Barretos, é comum observar na mesma lâmina vários graus de alteração do feldspato, desde fresco (principalmente em microclíneo) a muito alterado (com substituição por argilominerais) ou parcialmente dissolvido (com porosidade alveolar). O hábito do argilomineral que substitui o feldspato, observado em imagens de MEV, é indicativo de illita. 

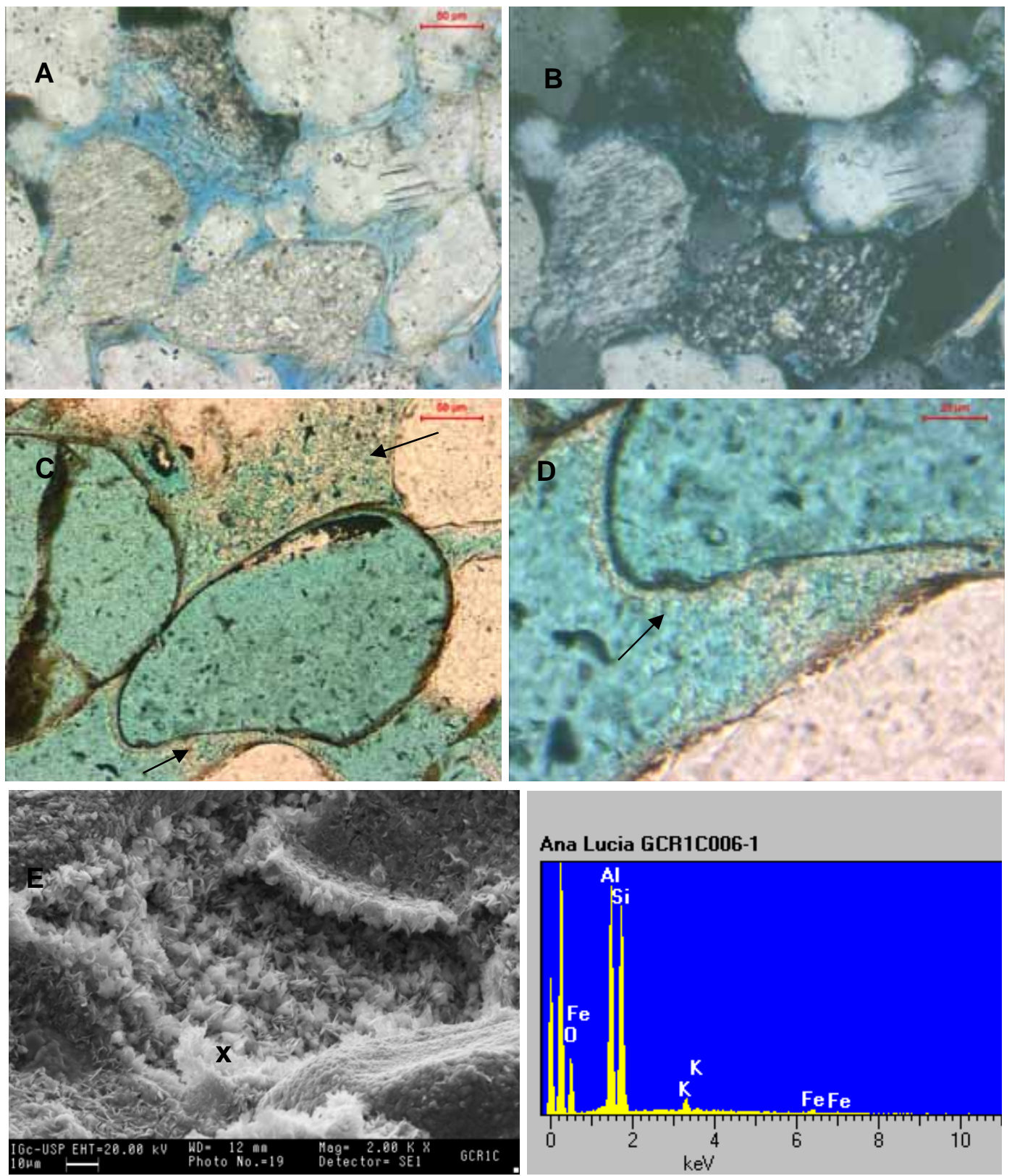

\section{Ana Lucia GCR1C006-1}
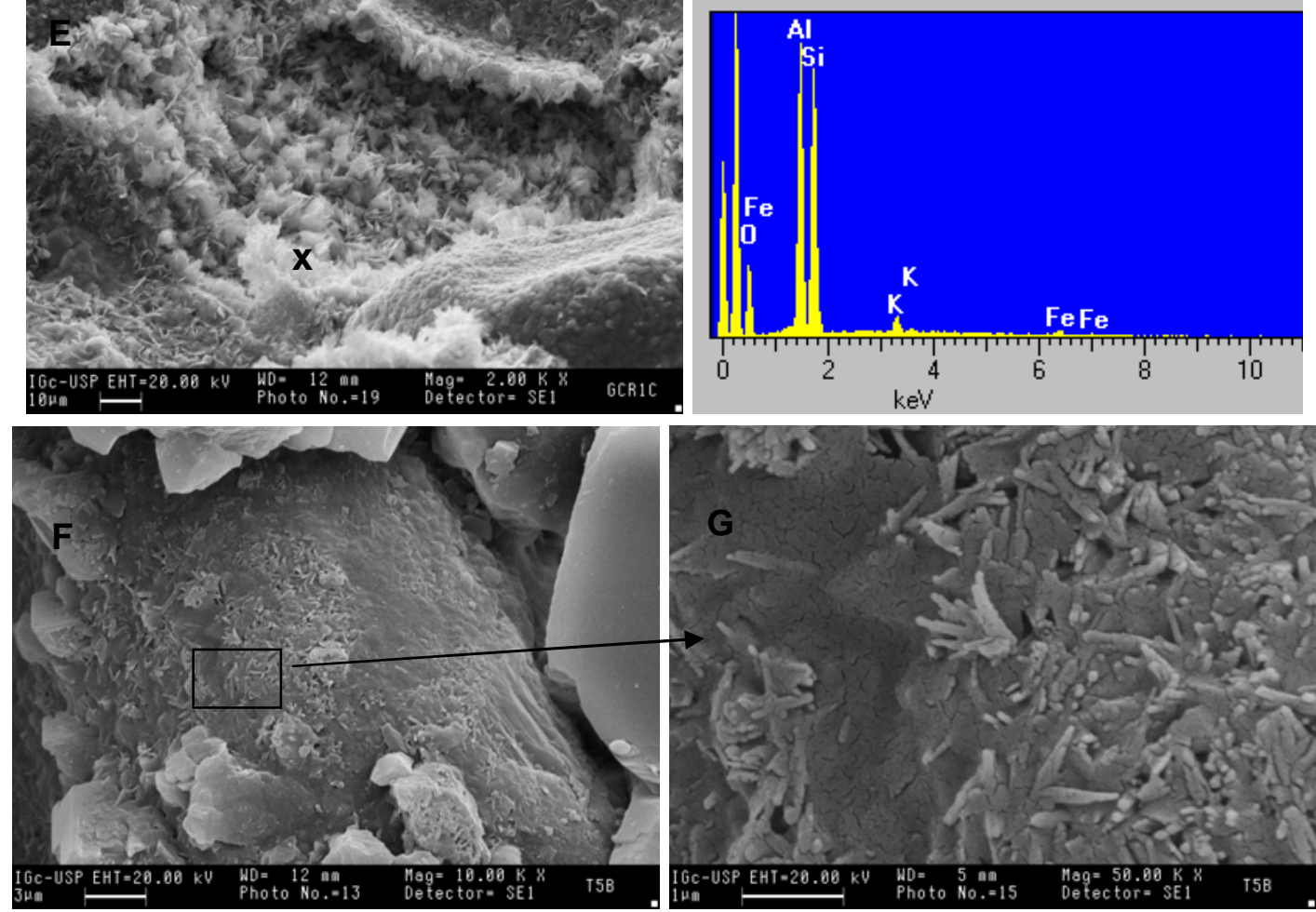

Figura 6.8 - A, B) substituição pseudomórfica de argilominerais em grãos de feldspato, os quais apresentam aspecto "sujo" ao microscópio. Petrofácies FA2c, poço Presidente Epitácio, $1732 \mathrm{~m}$. C, D, E) franjas e agregados intersticiais de argilominerais (setas) em arcabouço de grãos instáveis completamente lixiviados (poros móldicos). A imagem de MEV (fotomicrografia E) mostra que os argilominerais possuem hábito pseudohexagonal subédrico, cuja composição química qualitativa é indicativa de caulinita. Petrofácies FA1p, 
poço Santa Rosa do Viterbo, $100 \mathrm{~m}$. F, G) argilomineral de hábito ripiforme (paligorskita?) que ocorre na petrofácies QA2c, poço Matão, $474 \mathrm{~m}$.

Em amostras de superfície e em poços rasos da zona de afloramento, foram reconhecidos agregados intersticiais de argilominerais com hábito vermiforme, além de franjas de baixa birrefringência, cuja composição química qualitativa sugere composição caulinítica ( $\mathrm{Si}, \mathrm{Al}, \mathrm{O}$, $\pm \mathrm{Fe}, \mathrm{K}$ ). No poço de Santa Rosa do Viterbo, a grande intensidade de lixiviação de grãos instáveis ( $6 \%$ de porosidade alveolar e móldica), provavelmente em condições de intemperismo, parece ser o processo responsável pela neoformação de caulinita.

Argilominerais com hábito ripiforme e de "espada" (figura 6.8G), dispostos sobre cutículas envoltórias aos grãos, foram reconhecidos em uma amostra da petrofácies QA2p no poço de Matão (520 m) e são sugestivos de argilominerais evaporíticos, possivelmente paligorskita, mas infelizmente não foi possível obter sua composição química qualitativa por EDS. A presença de argilominerais evaporíticos (provável paligorskita) na Formação Pirambóia já foi aventada anteriormente por Donatti (2002) em arenitos do topo desta unidade, no mesmo contexto estratigráfico da petrofácies QA2p do poço de Matão.

\section{Betume}

O cimento de betume foi identificado em arenitos feldspáticos (petrofácies FAb) da porção inferior da Formação Pirambóia, em amostras de afloramento de arenito asfáltico no centro-leste paulista, região de Bofete, Angatuba e Guareí.

Em escala de afloramento, este cimento imprime aspecto listrado aos arenitos, devido à cimentação parcial seletiva dos estratos (figura 6.9). O betume impregna preferencialmente os estratos mais permeáveis, mas foi identificado tanto em fácies sedimentares de contexto de dunas quanto de interdunas. Aparentemente apenas os horizontes pelíticos mais espessos das interdunas subaquosas constituíram barreira eficiente à cimentação (figura 6.9).

A entrada de petróleo nos arenitos citados, segundo modelo genético de Araújo (2003), está associada ao sistema petrolífero Irati-Pirambóia, cuja geração se deu nos folhelhos betuminosos da Formação Assistência, com migração vertical através de estruturas extensionais de direção NW. A geração do óleo estaria associada às intrusões de soleiras de diabásio da Formação Serra Geral, datadas do 
Cretáceo Inferior (129-134 Ma), e a acumulação preferencial nos arenitos do domínio inferior da Formação Pirambóia ocorreu pela presença de armadilhas estratigráficas representadas pelas camadas pelíticas das fácies fluviais e de interdunas. Esse autor acredita que a transformação do óleo em asfalto deve-se à sua degradação provocada pela exumação do reservatório, após o final do Cretáceo.

A amarração cronológica da fase de cimentação de betume nos arenitos da Formação Pirambóia abre a possibilidade de situar os outros eventos diagenéticos de forma relativa à entrada do petróleo. As relações espaciais reconhecidas entre os cimentos da petrofácies FAb revelam que a entrada de óleo nos arenitos foi posterior à fase de cimentação eodiagenética (infiltração mecânica de argila e geração de cimento de feldspato potássico) e às etapas de neoformação de argilominerais e de incipiente cimentação de quartzo. Já a porosidade secundária intragranular (porosidade alveolar) é nitidamente posterior ao betume. Há também fase de geração de concreção carbonática, muito provavelmente nas condições superficiais atuais, cujo cimento de calcita substitui o de betume e preenche poros secundários tardios (figura 6.9).

A entrada de petróleo no reservatório pode retardar significativamente os principais processos diagenéticos, pelo fato do óleo deslocar a água do meio poroso e, por ser um fluido não condutivo em termos iônicos, inibir de forma considerável as reações químicas (Dixon et al. 1989), em especial a cimentação de quartzo e as transformações minerais. Previamente ao "congelamento" da diagênese com a entrada de óleo, a porosidade nos reservatórios pode ser ampliada (geração de porosidade secundária) pela ação sobre a rocha dos ácidos carboxílicos resultantes da maturação do petróleo, conforme demonstrado experimentalmente por Surdam et al. (1984). Através desta ação, ocorrem dissolução de cimentos carbonáticos e lixiviação do alumínio na forma de complexos orgânicos. 

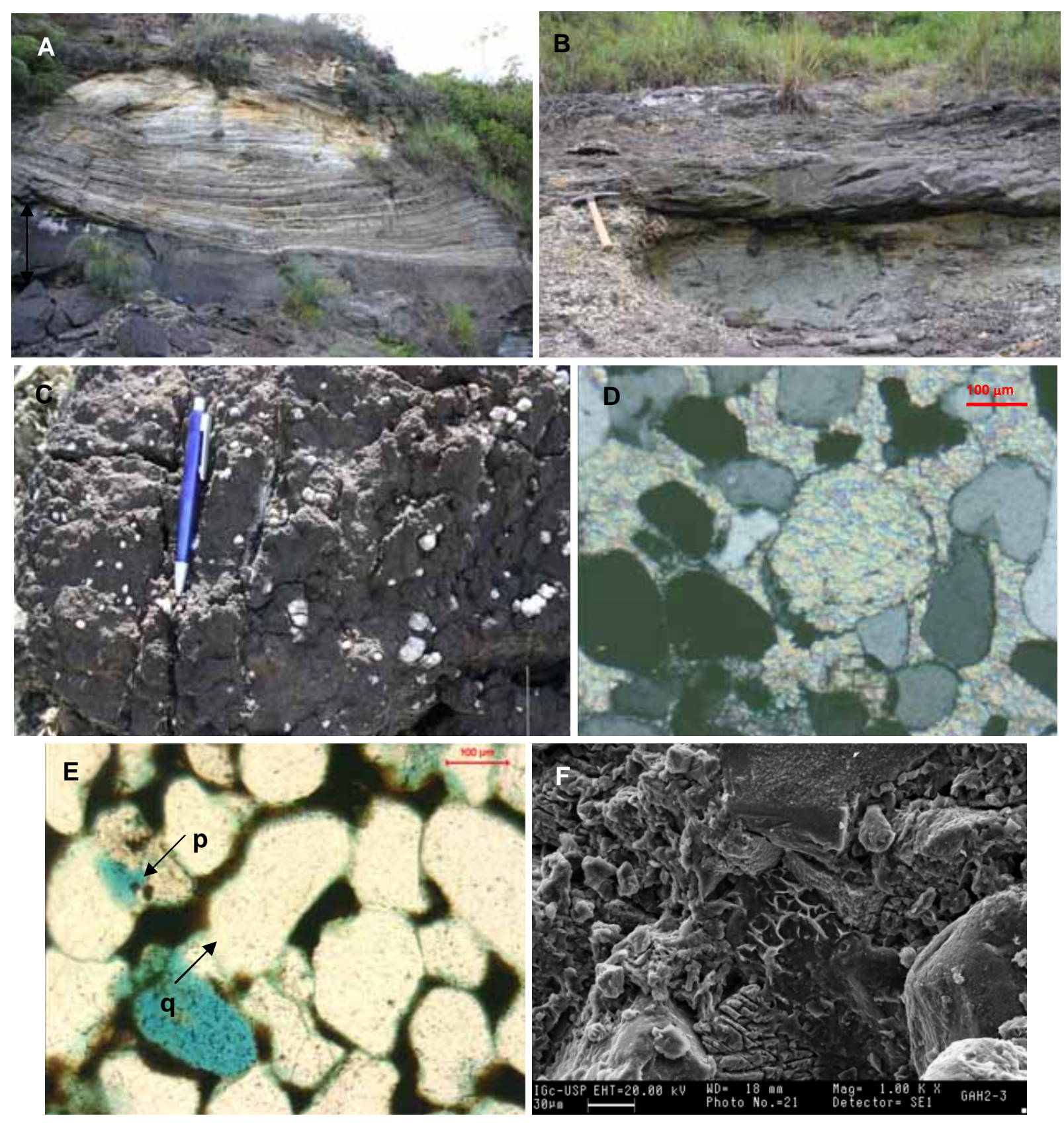

Figura 6.9 - Cimento de betume nos arenitos da Formação Pirambóia. A) Contraste entre duas distribuições de betume: seletiva, na fácies de estratificação cruzada acanalada (duna), o que confere aspecto listrado à camada superior, e generalizada, na fácies inferior (interduna úmida), totalmente impregnada. Jazida Betumita, Anhembi. B) Cimentação preferencial da camada de arenito com estratos cruzados (superior), sobreposta a horizonte síltico não cimentado por betume (interduna inundada). Afloramento da Rodovia SP280, km 174, Bofete. C) Detalhe de concreções carbonáticas (brancas) em horizonte impregnado por asfalto. Jazida Betumita, Anhembi. D) Fotomicrografia da concreção carbonática, com a calcita substituindo o cimento de betume intersticial e preenchendo porosidade secundária em feldspato lixiviado. Na imagem de MEV (F) de amostra de concreção, é possível reconhecer neoformação de argilomineral de hábito crenulado sobre grão detrítico. E) Fotomicrografia de arenito com cimento de betume obstruindo totalmente o espaço intergranular. Notar porosidade secundária alveolar (p) e cimento de quartzo (q). Jazida Itatigue, Guareí. 
A acumulação de óleo, posteriormente transformado em asfalto, nos arenitos da Formação Pirambóia ocorreu em condições de efetivo soterramento, posterior à fase de compactação química e de cimentação de quartzo. Não se pode afirmar, porém, se a entrada de óleo foi precedida por fase de geração de porosidade secundária devido à ação de ácidos carboxílicos uma vez que estas feições diagenéticas podem ter sido ampliadas consideravelmente pelo efeito do intemperismo atual.

\section{Sílica de baixa cristalinidade e criptocristalina}

Cimentação por opala e calcedônia foi reconhecida em amostras de superfície da Formação Botucatu (petrofácies QA1s) e em poço relativamente profundo, próximo à borda da bacia, em Batatais (326 m). É caracterizada pela presença de franjas poro-envolventes, com cerca de $20 \mu \mathrm{m}$ de espessura, de sílica isótropa (opala), sucedida de sílica criptocristalina (calcedônia) e fibrorradiada intersticial. A opala só foi reconhecida em amostras de superfície (Pedreira São Bento em Araraquara), ao passo que em subsuperfície ocorre exclusivamente a calcedônia, esta última aparentemente substituindo a primeira (substituição pseudomórfica por calcedônia fibrorradiada nas franjas). A análise destes cimentos ao MEV permitiu observar que as franjas são constituídas por lepisferas de cristobalita e que a calcedônia apresenta textura lisa (figura 6.10).

A seqüência completa de precipitação, tendo em vista as relações de sobreposição de cimentos, é: 1) opala-cristobalita em franjas que revestem a superfície externa dos poros; 2) calcedônia criptocristalina, formando fina película sobreposta às franjas; 3) calcedônia fibrorradiada intersticial, na forma de mosaicos; e 4) quartzo microcristalino ("megaquartzo"), com ocorrência muito localizada. Esta seqüência evidencia aumento progressivo de tamanho de cristais e do grau de cristalinidade dos cimentos e é comum em eventos hidrotermais ou de silicificação superficial (formação de silcretes) (Thiry \& Millot 1987). A opala é a forma mais instável e de mais baixa cristalinidade da sílica autígena, sendo comumente substituída por calcedônia e a calcedônia por quartzo no decorrer da diagênese, através de reações de dissolução e reprecipitação (Williams et al. 1985). A solubilidade de cada polimorfo de sílica cresce inversamente em relação ao grau de cristalinidade e é controlada pelo $\mathrm{pH}(>9)$, temperatura, saturação do meio e área superficial. Williams et al. (1985) argumentam que a temperatura não é o 
parâmetro essencial na variação da solubilidade dos polimorfos de sílica, mas que seu efeito é primordial no aumento das velocidades de reação e precipitação de um tipo para outro. Em condições de baixas temperaturas, a precipitação dos polimorfos mais instáveis do ponto de vista químico é controlado primordiamente pela presença de germes de cristalização (representados pelos próprios grãos detríticos de quartzo ou fragmentos de sílica biogênica) e pelo grau de saturação com respeito a cada polimorfo de sílica. Quanto menor o conteúdo de silte+argila detríticos nos sedimentos, os quais concorrem com o consumo de sílica dissolvida caso haja transformações químicas dos argilominerais, mais favorável a precipitação seqüencial de polimorfos de sílica (McBride 1989).

A silicificação nos arenitos da Formação Botucatu é aparentemente póscompactacional tendo em vista as relações de contato intergranular do arcabouço, com predomínio do tipo planar e presença rara do tipo côncavo-convexo. A localização marginal das ocorrências em relação à zona aflorante das unidades favorece a hipótese de cimentação telodiagenética superficial, como aventado por França et al. (2003).

Com relação à petrofácies QA1s do poço de Batatais, o conteúdo de cimento de quartzo sintaxial é anomalamente alto (16\%) e coexiste com franjas de calcedônia e calcedônia intersticial (figura 6.10). Esta situação permite evocar a possibilidade de temperaturas altas em condições de soterramento pouco profundo, as quais poderiam ter favorecido a dissolução-reprecipitação das franjas de opala ou calcedônia diretamente para quartzo. Neste local, é possível que tenha ocorrido percolação de fluidos hidrotermais ao longo de estruturas rúpteis, como falhas e diques.

Vale lembrar os estudos experimentais de silicificação de amostras de arenito da Formação Botucatu, realizados por Paraguassu (1972), nos quais foi demonstrado que a saturação de sílica amorfa em água destilada é rapidamente alcançada, em condições superficiais de temperatura, apenas pela percolação contínua da água através de arenitos quartzosos permeáveis. Segundo este autor, a silicificação observada ao longo da borda aflorante da Formação Botucatu, no Estado de São Paulo, poderia ser explicada pela evaporação das águas subterrâneas saturadas neste componente (ascensão por capilaridade e precipitação), mesmo sob as condições climáticas úmidas atuais. 

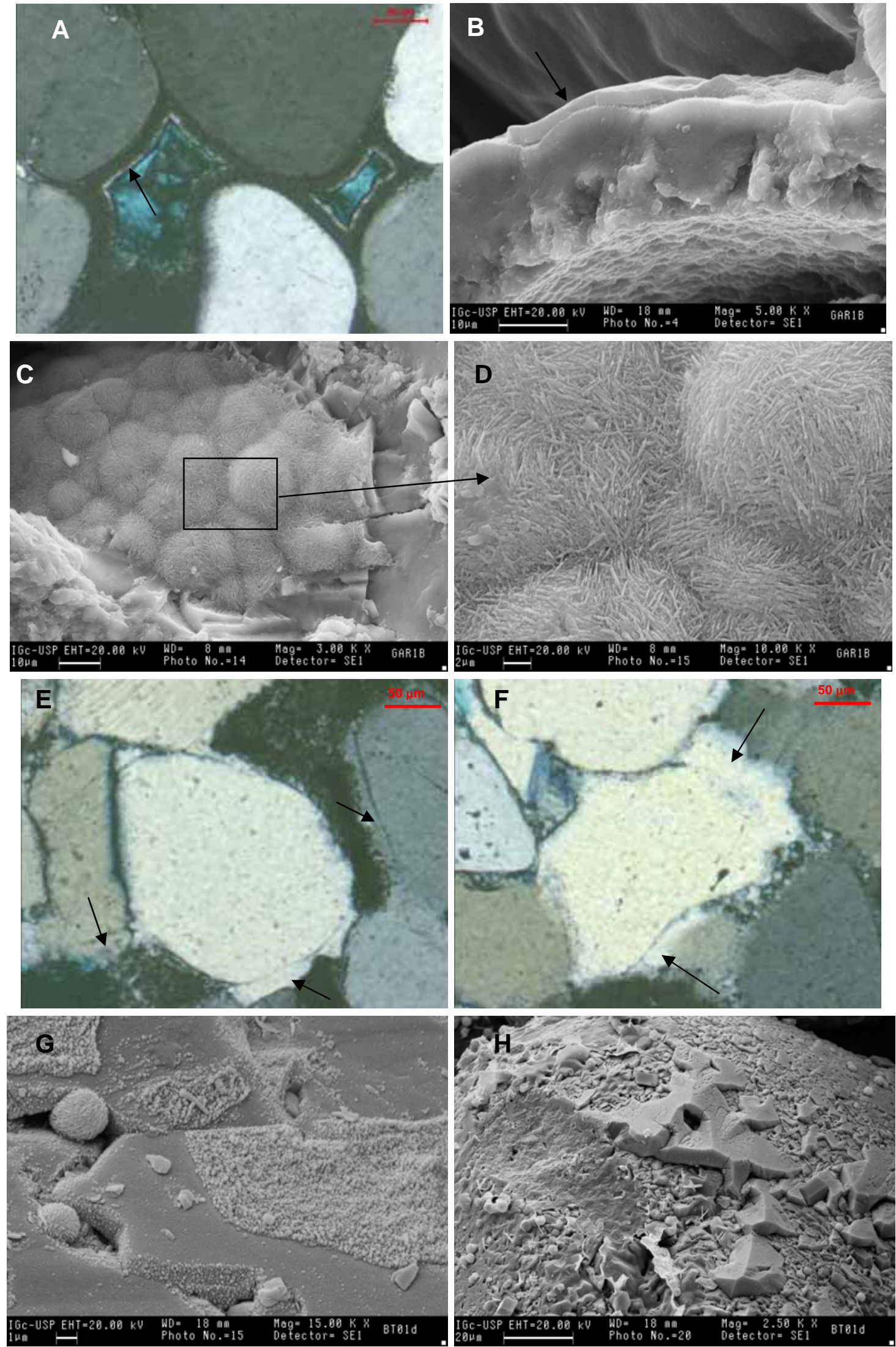

Figura 6.10 - Cimentos de sílica de baixa cristalinidade. A, B) Franjas poro-envolventes de opala (isótropa) de até $20 \mu \mathrm{m}$ de espessura. Notar que a borda externa na franja apresenta birrefringência baixa (seta fina). Na imagem de MEV em corte transversal à franja (B), notar duas gerações de cimento, uma inferior mais espessa (cerca de $10 \mu \mathrm{m}$ ) e outra sobreposta, mais fina ( $2 \mu \mathrm{m}$, seta fina), a qual corresponde à borda anisótropa da imagem 
A. C, D) Imagem de MEV da superfície das franjas formadas por lepisferas de cristobalita. E, F) Cimentação extensiva por quartzo sintaxial (setas) e coexistência com franjas de calcedônia fibrosa e calcedônia intersticial. Notar limite irregular entre as lamelas de quartzo e a calcedônia. G, H) Imagens de MEV ilustrativas das texturas do cimento de quartzo: lamelas contínuas sobre o grão, sobrepostas por delgada franja de sílica criptocristalina (G), ou bordas piramidais incipientes $(\mathrm{H})$. Notar coexistência com sílica de baixa cristalinidade (lepisferas dispersas no espaço poroso). A - D) Amostra de superfície, Pedreira São Bento, Araraquara. E-H) Fragmento de calha, poço Batatais, $330 \mathrm{~m}$.

\section{Calcita}

A calcita constitui o componente diagenético mais abundante dos arenitos analisados, onde chega a representar até 36\% da rocha. Sua distribuição é heterogênea em subsuperfície (figura 6.11), mas geralmente ocorre em profundidades abaixo dos $300 \mathrm{~m}$ (exceto poço de Bauru) e inexiste em amostras de afloramento. Caracteriza-se por textura espática e poiquilotópica e preenche parcial ou totalmente o espaço intergranular. As relações espaciais com o arcabouço e outros cimentos, inclusive de substituição pseudomórfica, permitem interpretar a calcita como o cimento mais tardio na evolução diagenética, exceto os cimentos de argilominerais e de sílica reconhecidos em amostras de superfície. As amostras de fragmentos de calha cimentadas por calcita são preferencialmente de granulometria areia fina e areia média e apresentam arcabouço frouxo ( $\operatorname{IP}_{\mathrm{kp}}$ entre $10 \%$ e $23 \%$ ), situação que pode significar cimentação preferencial nos horizontes mais permoporosos da rocha, por exemplo lentes de fluxo granular das frentes de dunas e arenitos conglomeráticos fluviais. A análise dos arenitos cimentados por calcita no sistema MEV-EDS permite atribuir ao cimento composição praticamente pura (36,8 $\%$ de cálcio no poço de Barretos), com traços de silício $(0,3 \%)$. À análise por catodoluminescência, caracteriza-se por luminescência laranja intensa, sem zoneamentos composicionais.

A calcita está presente preferencialmente nas petrofácies da Formação Pirambóia e só foi reconhecida na Formação Botucatu nos poços de Matão e Bauru. A porção superior da Formação Pirambóia, abaixo do contato com os arenitos Botucatu, constitui horizonte preferencial de cimentação interticial de calcita na bacia. A intensa cimentação condicionada pela discordância entre as duas unidades pode ter sido favorecida pela presumível diferença de permeabilidade entre arenitos finos acima (Botucatu) e arenitos médios a conglomeráticos abaixo (Pirambóia). No entanto, a calcita obstrói parcial a totalmente o espaço poroso de arenitos de 
diversas granulometrias (finos a médios) e arranjos internos, abaixo da discordância Pirambóia-Botucatu.

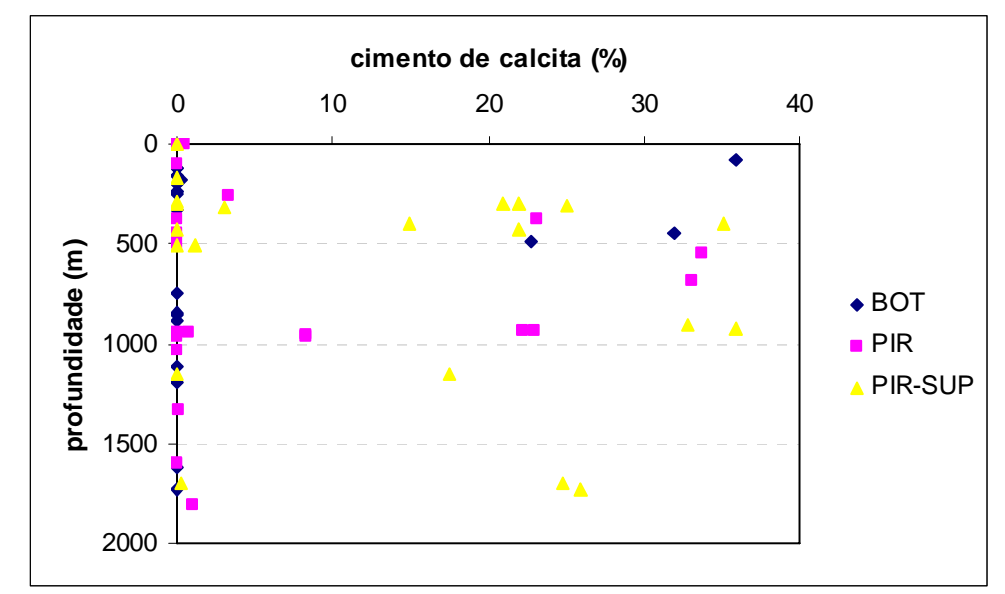

Figura 6.11 - Distribuição heterogênea do cimento de calcita com a profundidade. Notar que este cimento é muito mais freqüente nos arenitos da Formação Pirambóia (PIR) do que nos da Formação Botucatu (BOT).

Feições de dissolução do cimento calcítico são menos comuns nos fragmentos de calha de poços profundos do que em poços de pequeno confinamento. Porém, a preservação e amostragem preferencial, no processo de perfuração dos poços de capação de água, de horizontes intensamente cimentados, em comparação aos porosos, pode levar à subestimativa destas feições.

\section{Compactação mecânica e química}

As feições de compactação física e química nos arenitos das formações Pirambóia e Botucatu são incipientes a moderadas, como pode ser atestado pela presença de arcabouço essencialmente aberto (IPKp <40\%) e predomínio de contatos intergranulares planares e pontuais. As feições mais contundentes de compactação mecânica, como fraturamento de grãos de feldspato e amassamento de fragmentos líticos dúcteis, são observadas localmente em arenitos da Formação Botucatu (poço de Presidente Epitácio) e na porção basal da Formação Pirambóia (poços Lins, Olímpia, Fernandópolis e Presidente Prudente), em profundidades maiores que $1000 \mathrm{~m}$ (figura 6.12). 

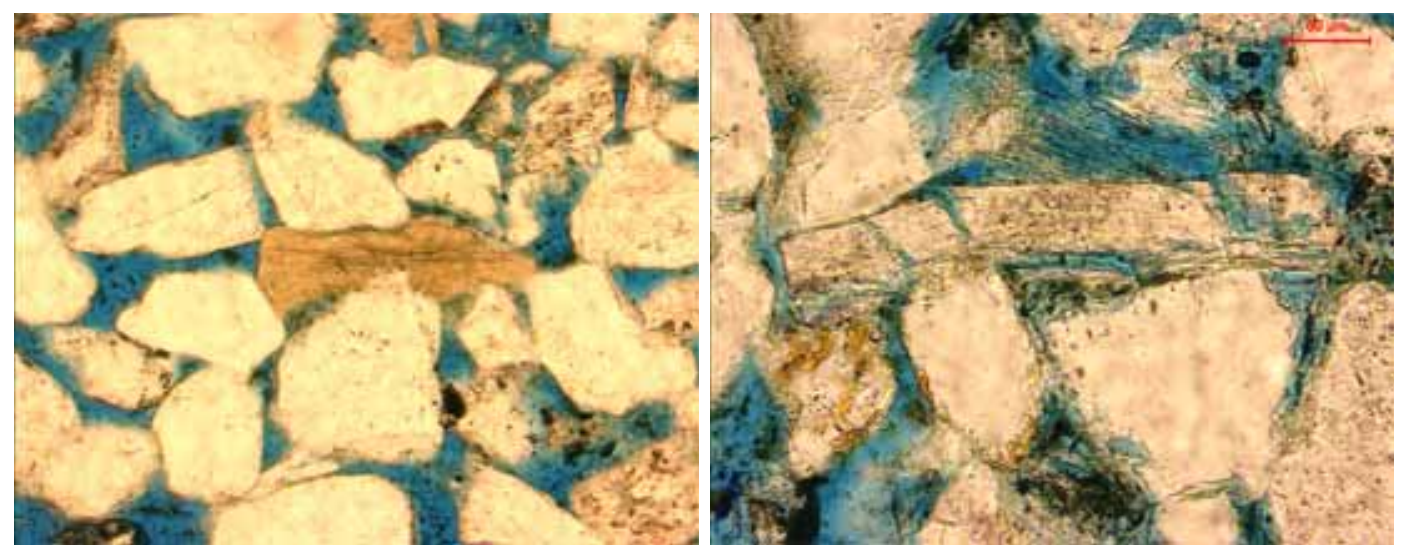

Figura 6.12 - Feições de compactação mecânica nos arenitos porosos das formações Pirambóia e Botucatu, como fragmento pelítico amassado (imagem da esquerda) e grão de feldspato quebrado (direita).

Existem três propostas para avaliação quantitativa da intensidade da compactação versus cimentação utilizando informações petrográficas (Houseknecht 1987, Lundegard 1992 e Ehrenberg 1995), as quais permitem determinar o impacto relativo da perda (ou não) de porosidade e se esta perda está relacionada com variação do volume total da rocha ao longo da história diagenética. $\mathrm{Na}$ proposta de Houseknecht (1987), a perda de porosidade por compactação é estipulada pela diferença entre a porosidade atual e uma porosidade inicial teórica de 40\%. Para Lundegard (1992), este cálculo simplificado subestima a perda de porosidade por compactação, principalmente por não levar em consideração o efeito da redução do volume total de rocha, por exemplo, decorrente da dissolução por pressão. Este autor espressa a perda de porosidade por compactação (COPL) e por cimentação (CEPL) como porcentagem relativa ao volume total original da rocha (ver equações na figura 36), adotando-se uma porosidade inicial (Pi) de 45\%. Na proposta de Ehrenberg (1995), são utilizadas as mesmas equações propostas por Lundegard (1992) para calcular a porcentagem da porosidade original remanescente (XPOR) e a porcentagem da porosidade total perdida por compactação (XCOM). A variável XCOM equivale ao "índice de compactação" definido inicialmente por Lundegard (1992) e estipula que valores entre 0 e $50 \%$ representam predomínio de perda de porosidade por cimentação e entre $50 \%$ e 100\% predomínio de perda de porosidade por compactação. O gráfico da correlação das variáveis XPOR e XCOM com a profundidade permite visualizar de que forma se deu a redução da porosidade e o quanto esta foi diminuída ao longo da diagênese. 
A avaliação dos diagramas da figura 6.13 revela que cimentação e compactação atuaram em intensidades mais ou menos semelhantes na redução da porosidade original das formações Pirambóia e Botucatu. O gráfico de Lundegard (1992) permite notar a existência de uma população de dados das duas unidades, com porosidades entre $10 \%$ e $30 \%$, cujo principal mecanismo de redução do espaço poroso foi a compactação. A correlação entre os parâmetros XPOR e XCOM (Ehrengberg 1995) demonstra também que apesar da compactação ter sido importante na redução da porosidade de arenitos (valores de XCOM $>50 \%$ ), há ainda bastante espaço poroso remanescente. Nos gráficos de correlação entre os parâmetros XPOR e XCOM com a profundidade (figura 6.14), fica mais clara a tendência de perda progressiva do espaço poroso por compactação com o aumento do soterramento, principalmente em arenitos da Formação Pirambóia.
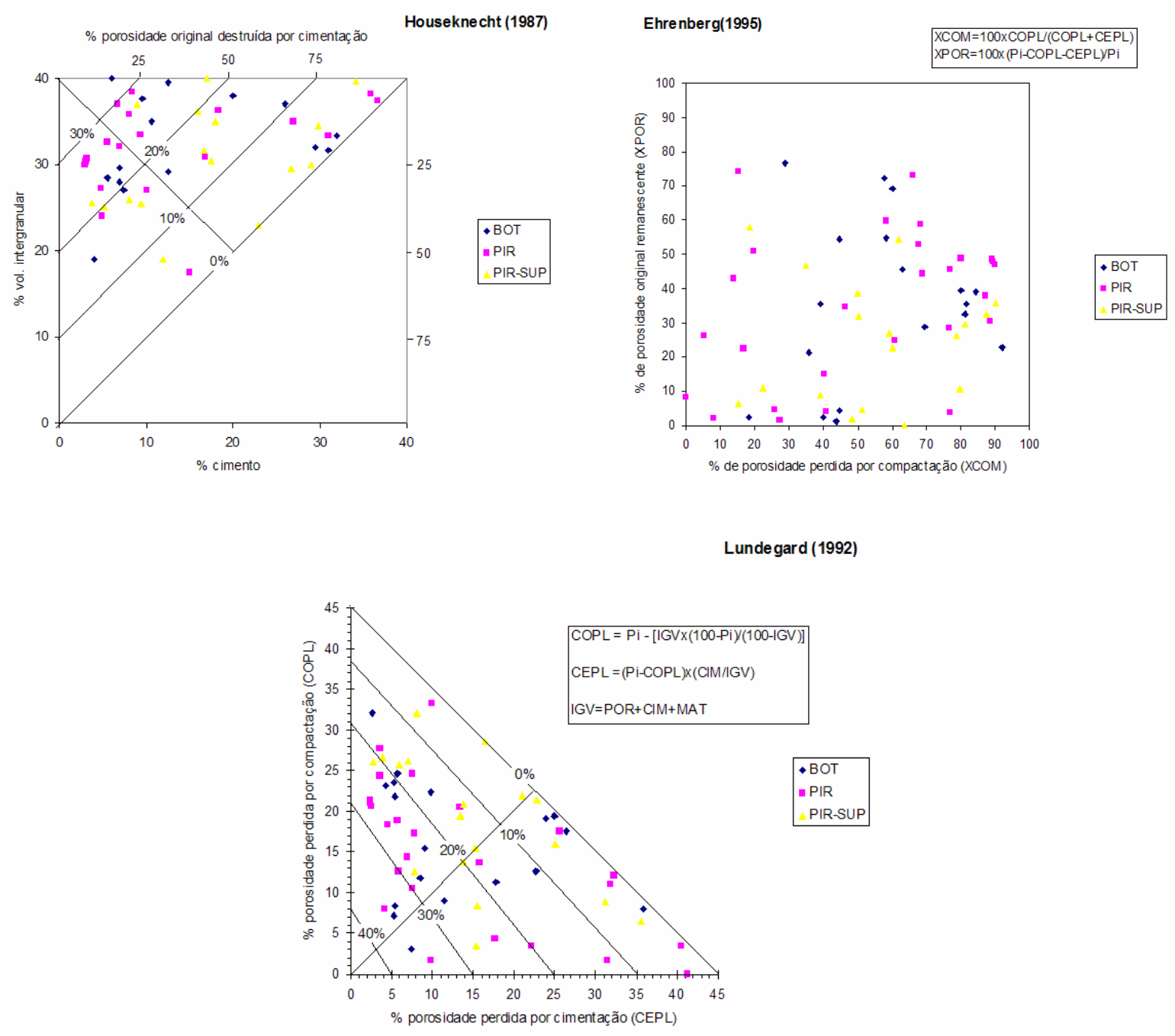

Figura 6.13 - Avaliação quantitativa da perda de porosidade dos arenitos das formações Pirambóia e Botucatu. 
Ehrenberg(1995)

Ehrenberg(1995)
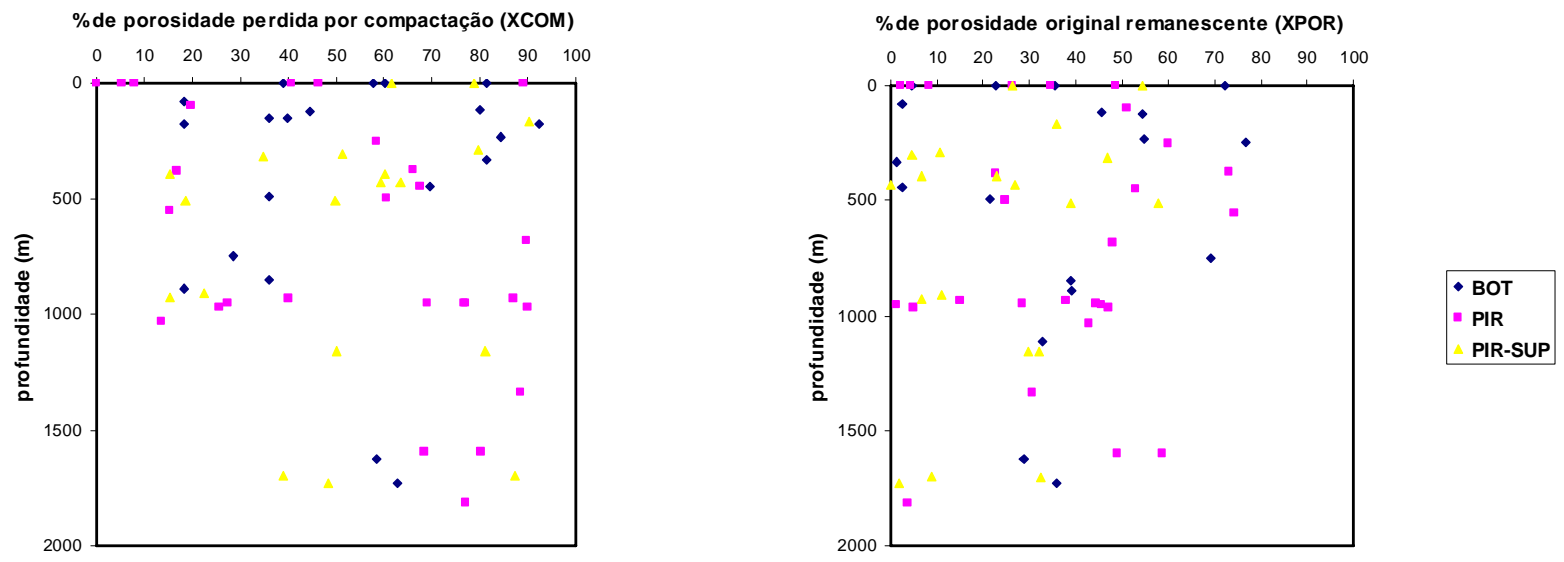

Figura 6.14 - Avaliação relativa da influência da compactação e cimentação na perda de porosidade com a profundidade.

Avaliando o impacto da compactação e cimentação sobre a porosidade e sua relação com parâmetros deposicionais e diagenéticos (figura 6.15), torna-se nítido o maior percentual da porosidade original preservada nas fácies dunares em comparação com as interdunares. No caso das petrofácies com cimentos intersticiais tardios (principalmente calcita), a tendência progressiva de perda de porosidade por compactação com o aumento da profundidade é menor do que nas petrofácies porosas.
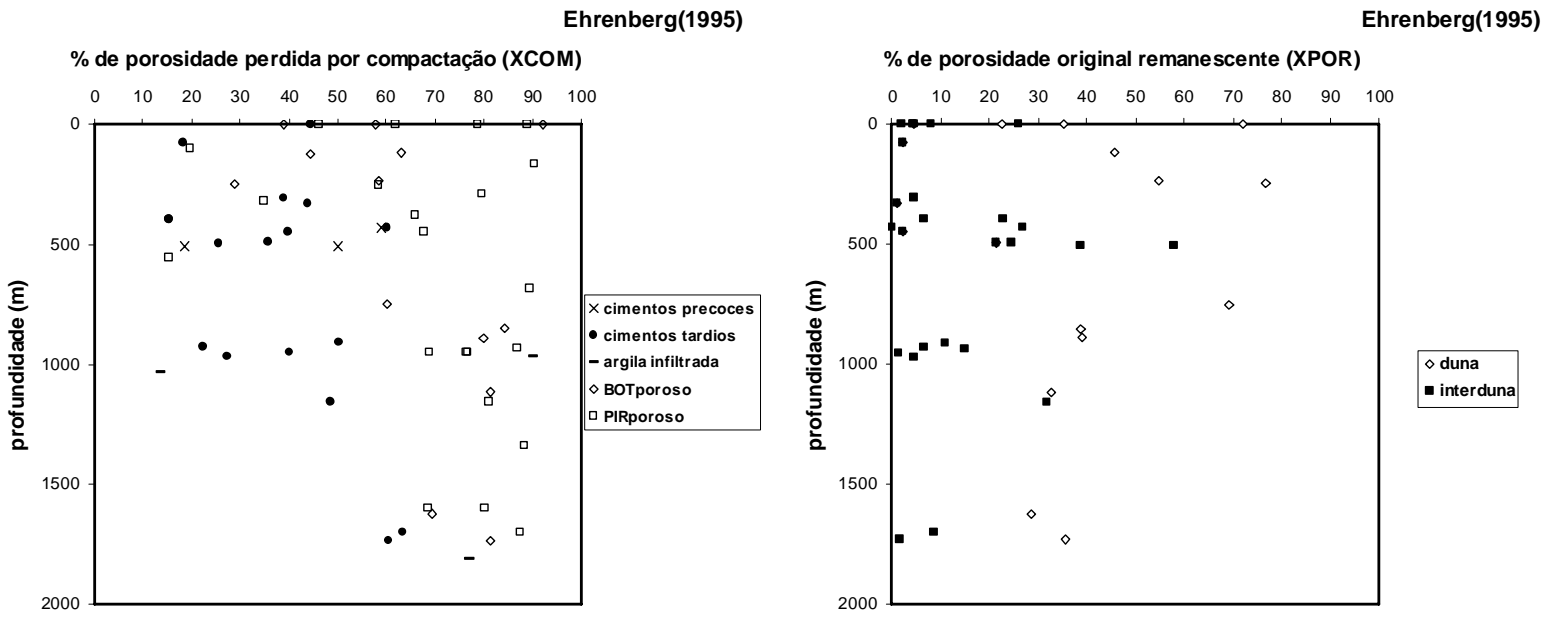

Figura 6.15 - Avaliação da perda de porosidade em comparação a parâmetros deposicionais e diagenéticos. 


\section{Geração de porosidade secundária}

A porosidade das amostras de subsuperfície estimada em seção delgada (macroporosidade) é bastante variável, desde traços até cerca de 40\%. Há amplo predomínio da porosidade intergranular em relação à porosidade intragranular (no geral, na proporção de 10:1), esta última tipicamente secundária, relação que tende a diminuir em direção às porções mais rasas da bacia e mais próximas da área de afloramentos. A porosidade intraconstituinte é basicamente alveolar (honeycomb) e móldica em feldspato potássico e plagioclásio, móldica em franjas de opala, de contração e de dissolução parcial no cimento carbonático (figura 6.16). Em amostras de afloramento e alguns poucos poços rasos, foram reconhecidos até $6 \%$ de porosidade móldica em arenitos da Formação Pirambóia. Não há exatamente um tipo preferencial de feldspato que apresente dissolução química, podendo coexistir, na mesma rocha, microclínio, ortoclásio e plagioclásio em graus variados de alteração, embora seja muito mais freqüente a ocorrência de microclínio fresco comparativamente aos outros dois tipos de feldspato. Nos arenitos com cimento carbonático, a porosidade secundária predominante é intraconstituinte (intracimento e intragranular alveolar).

A distribuição da porosidade nos arenitos das formações Pirambóia e Botucatu é heterogênea (figura 6.17), sem tendência nítida de variação com a profundidade ou o domínio faciológico. Com relação à porosidade secundária intraconstituinte, o gráfico da figura 6.17 demonstra que ela tende a ser ampliada em profundidades rasas e na zona de afloramento (máximo de 10\% em amostra de superfície) em comparação à zona mais profunda da bacia. Na situação de maior soterramento das unidades (>1500 m), a porosidade secundária é ainda alta, 4,7\% (intracimento) no poço de Presidente Prudente e 2,8\% (intragranular) no poço de Fernandópolis, sendo característica dos arenitos da Formação Pirambóia. 

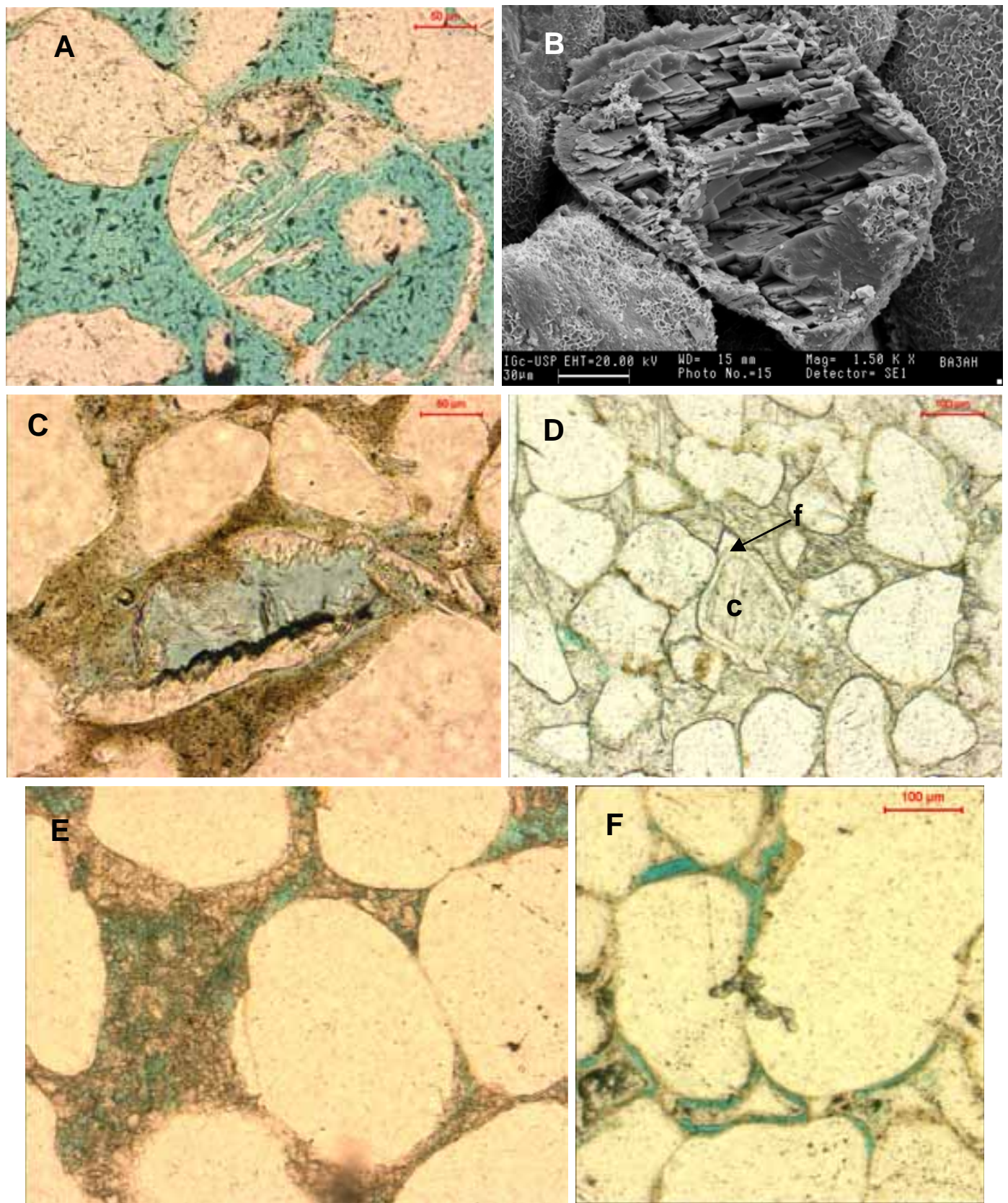

Figura 6.16 - Tipos de porosidade secundária reconhecidos nas unidades estudadas. A, B, C) Porosidade alveolar em grãos de feldspato potássico. A) Petrofácies QA2c, poço Barretos3, $914 \mathrm{~m}$. B) Imagem de MEV, petrofácies FA1p, poço Barretos, $990 \mathrm{~m}$. C) petrofácies FA1i, poço Olímpia, $1032 \mathrm{~m}$. D) Cimento de calcita preenchendo porosidade móldica (c) em feldspato. Notar cimento sintaxial preservado (f). Petrofácies FA1c, poço Barretos, $990 \mathrm{~m}$. E) Feição de dissolução de cimento carbonático intersticial. Petrofácies QA2c, poço Barretos, $914 \mathrm{~m}$. F) Porosidade móldica em prováveis franjas de opala. Petrofácies QA1s, poço Batatais, $326 \mathrm{~m}$. 

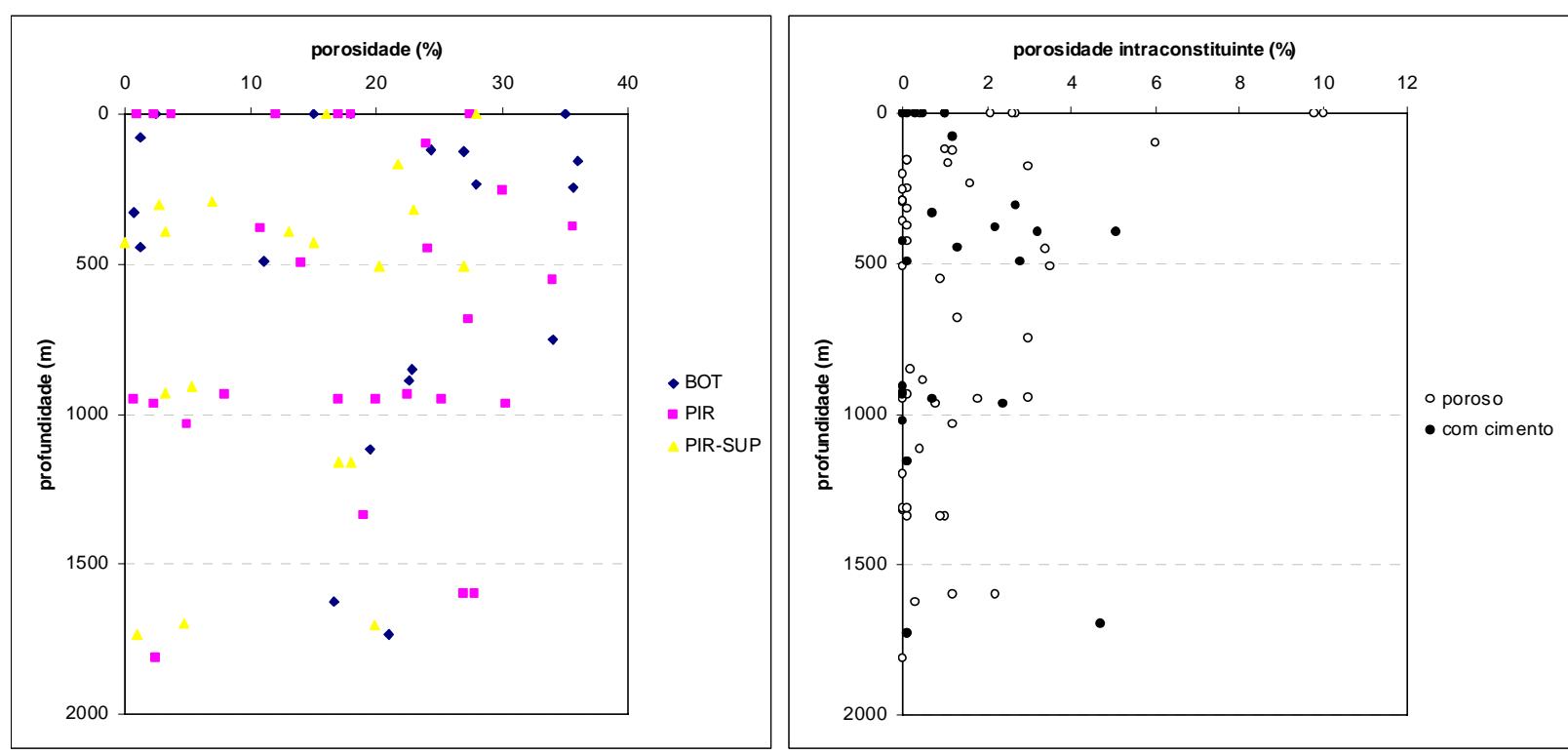

Figura 6.17 - Distribuição da macroporosidade total e da porosidade secundária em relação à profundidade de ocorrência.

As relações espaciais entre os poros secundários e o cimento tardio de calcita não evidenciam uma seqüência de eventos inequívoca, extrapolável para todo o conjunto de amostras. A Formação Botucatu é essencialmente porosa e apresenta cimento de calcita apenas no poço de Matão e Bauru; nestes locais, a calcita é posterior aos poros secundários alveolares e móldicos. O evento de cimentação de calcita nos arenitos da Formação Pirambóia é também posterior à fase de lixiviação parcial de feldspatos, visto que a calcita preenche poros intragranulares nos poços de Agudos, Araçatuba, Barretos, Batatais, Matão, Lins e Orlândia. Nos poços de Presidente Epitácio, Presidente Prudente e Sertãozinho, a calcita preenche exclusivamente o espaço intergranular. Como o cimento de calcita não apresenta variações composicionais identificáveis no MEV e na catodoluminescência, admitese aqui um único evento de cimentação tardia que obstruiu prefencialmente a porosidade dos arenitos da Formação Pirambóia, o qual é posterior à fase principal de geração de porosidade secundária nas unidades.

França et al. (2003) concluíram que o mecanismo gerador de porosidade secundária nos arenitos da Formação Botucatu seria a percolação pervasiva e profunda de águas meteóricas ácidas bacia adentro, a partir das zonas aflorantes. O fluxo intensivo destes fluidos agressivos, favorecido pela alta permeabilidade do 
aqüífero, seria responsável pela intensa lixiviação de grãos de feldspato, mesmo em grandes profundidades, e pela completa eliminação de calcita nas zonas de confinamento marginal e nos afloramentos.

Segundo a interpretação de França et al. (2003), a principal fase de geração de porosidade secundária nos arenitos das formações Pirambóia e Botucatu, responsável pela lixiviação de componentes instáveis mesmo em grandes profundidades, deu-se a partir de águas meteóricas provenientes da zona de afloramento, devido à criação de gradiente hidráulico na borda leste da bacia, determinando a implantação de regime telodiagenético nestas unidades.

\section{Outros cimentos}

Foram reconhecidos localmente anatásio autígeno, cimento de analcima, pirita e óxidos e hidróxidos de ferro intersticiais (Figura 6.18). O cimento de analcima intersticial ocorre em arenitos da interface estratigráfica das unidades Passa Dois e Pirambóia, no poço de Presidente Prudente (1795 m). A ocorrência de pirita é exclusiva dos arenitos asfálticos superficiais da Formação Pirambóia, na forma de cristais euédricos de cerca de $10 \mu \mathrm{m}$. O cimento de óxido/hidróxido de ferro intersticial é mais comum em amostras de afloramento. 

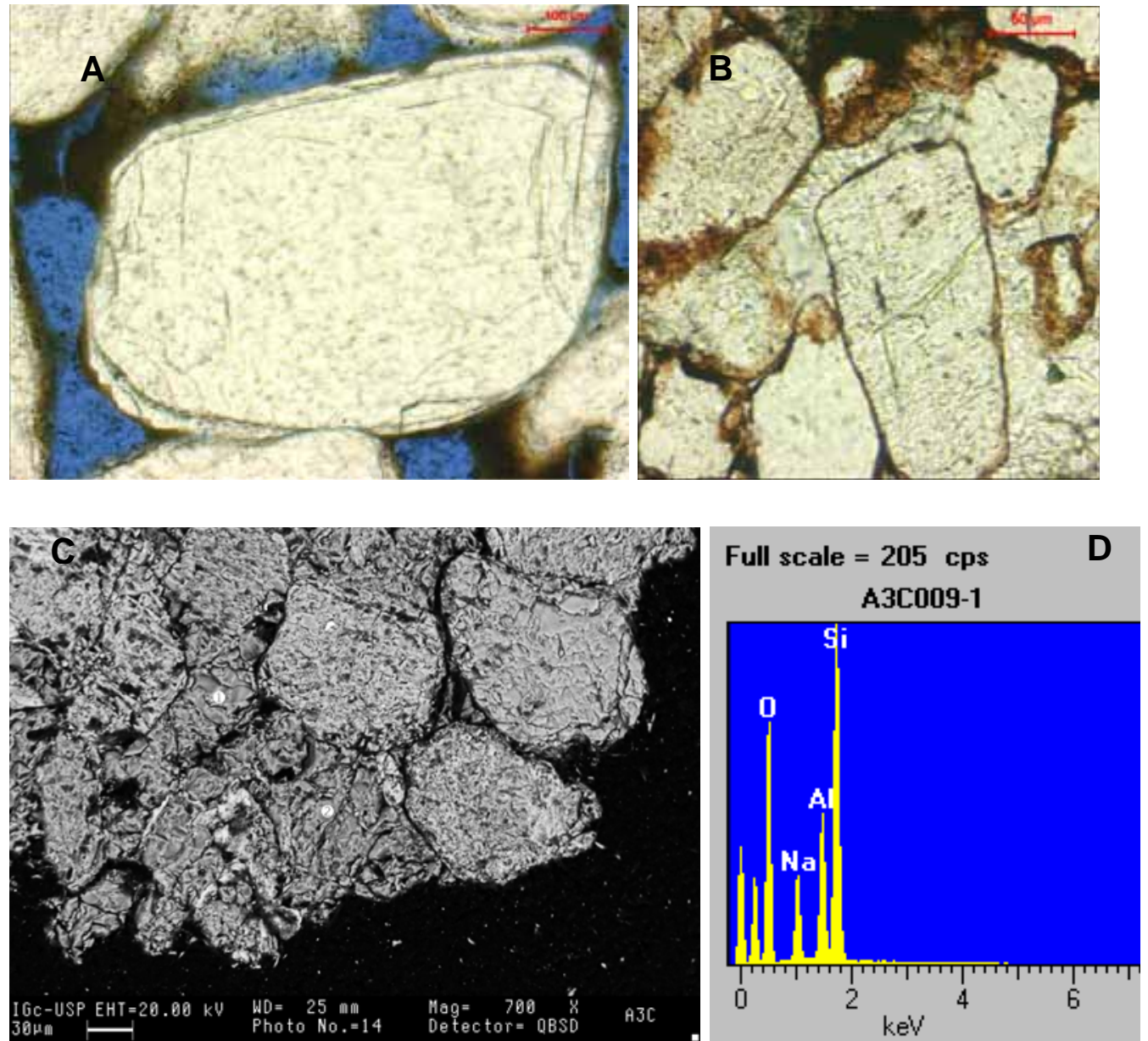

Figura 6.18 - Cimento de óxido de ferro na forma de franja poro-envolvente, em amostra de superfície (A) da porção superior da Formação Pirambóia. Cimento de analcima intersticial, de caráter isotrópico e com relevo negativo (B) em amostra de calha da base da Formação Pirambóia no poço de Presidente Prudente, $1976 \mathrm{~m}$. A composição semiquantitativa (D) deste cimento, no sistema MEV-EDS (C), é de 37,6\% 0; 5,9\% Na; $9,6 \% \mathrm{Al} ; 33,6 \% \mathrm{Si} ; 0,6 \% \mathrm{~K} ; 0,6 \% \mathrm{Ca} ; 0,4 \% \mathrm{Fe}$.

\subsection{Seqüência de eventos diagenéticos}

A figura 6.19 mostra a seqüência de eventos diagenéticos reconhecidos nos arenitos das formações Pirambóia e Botucatu em São Paulo. 


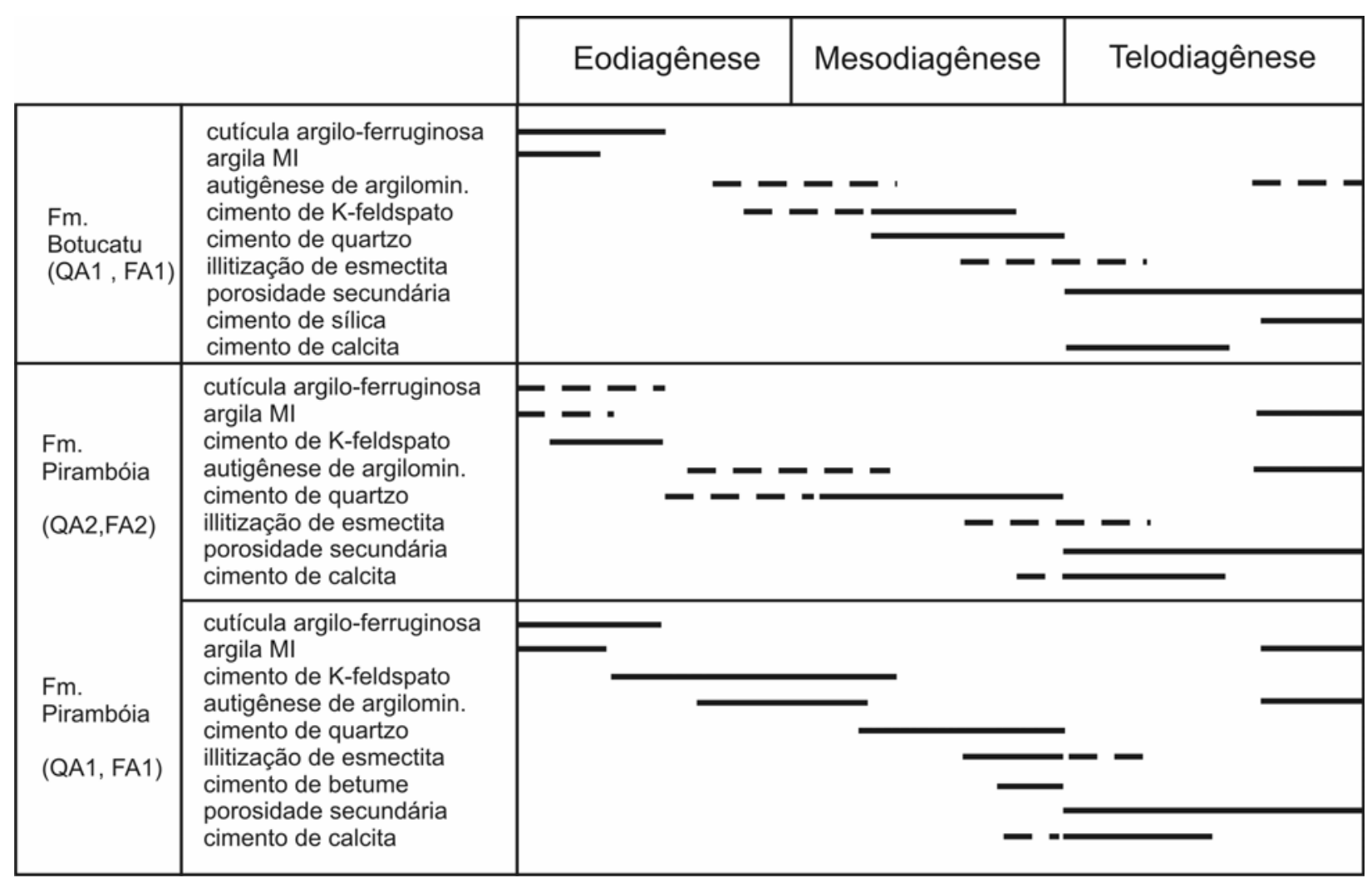

Figura 6.19 - Seqüência paragenética das formações Pirambóia e Botucatu em São Paulo. 


\section{AS FORMAÇÕES PIRAMBÓIA E BOTUCATU EM SUBSUPERFÍCIE}

As descrições e perfis de poços de captação de água nem sempre contêm informações sobre o limite entre as formações Pirambóia e Botucatu, uma vez que, também em subsuperfície, estas duas unidades litoestratigráficas são freqüentemente referidas em conjunto.

Existem pelo menos duas razões, de ordem prática, para o agrupamento das duas unidades, de forma indistinta, nos estudos hidrogeológicos. A primeira é a dificuldade de individualizar os arenitos eólicos de cada unidade a partir da simples análise visual dos diminutos fragmentos de rocha colhidos em amostras de calha. A segunda razão, especialmente no caso de poços de água, é a provável semelhança das unidades quanto ao comportamento em termos de vazão hidráulica, com exceção da fatia estratigráfica inferior da Formação Pirambóia, onde se tornam mais freqüentes as intercalações de pelitos em depósitos de interdunas.

Em virtude destes problemas, houve necessidade de revisar o material de calha e analisar os perfis elétricos dos poços para determinar as profundidades limítrofes entre as unidades e orientar a determinação da origem das amostras de calha quanto ao intervalo estratigráfico atravessado.

Os critérios para distinção entre intervalos estratigráficos basearam-se no contraste entre sistema eólico úmido Pirambóia e sistema eólico seco Botucatu, de acordo com o modelo de fácies elaborado por Giannini (2001). Segundo este modelo, a presença de fácies rudáceas no sistema Pirambóia superior, interpretada como fase de avanço de rios entrelaçados em contexto de recrudescimento tectônico, marcaria seu contato superior com os depósitos do sistema eólico seco Botucatu em boa parte da porção aflorante das duas unidades, em São Paulo e no Paraná. Procurou-se, então, verificar a continuidade desta associação de fácies na porção confinada da bacia, através da revisão do material de calha dos poços de captação de água nas litotecas do DAEE e CPRM e de alguns poços de prospecção de petróleo, inclusive como forma de testar e estender para subsuperfície o modelo de fácies anteriormente proposto.

A revisão dos poços de captação de água disponíveis na litoteca do DAEE revelou que das 76 perfurações, 15 foram paralisadas na Formação Botucatu. Em cerca de 50 poços, o limite entre as formações Pirambóia e Botucatu foi delimitado com segurança pela presença de níveis areno-conglomeráticos, interpretados como 
correspondentes às fácies rudáceas de origem fluvial e flúvio-eólica do sistema Pirambóia superior. Em cinco poços, a presença dos intervalos com rudáceos não foi reconhecida, porém, em seu lugar, notou-se a ocorrência de horizontes sílticos, de coloração rosa clara, fortemente cimentados por carbonato, que corresponderiam, portanto, ao provável limite entre depósitos eólicos das unidades Pirambóia e Botucatu. Em outros cinco poços, todos da região de Bauru, os dados demonstram a inxistência dos intervalos estratigráficos correspondentes à Formação Botucatu e à porção superior da Formação Pirambóia. Em apenas seis poços, o limite estratigráfico entre estas unidades foi considerado incerto, pois não pôde ser delimitado pela presença de níveis conglomeráticos, nem por horizontes preferencialmente cimentados.

A análise dos dados de poços permite observar que a prospecção de água subterrânea de fato prioriza a perfuração nos arenitos da Formação Botucatu e na porção superior da Formação Pirambóia. Enquanto isso, os intervalos mais basais desta unidade são deliberadamente evitados. Por este motivo, nem todos os poços atingem a Formação Pirambóia, e raros são aqueles que a atravessam por completo.

\subsection{Distribuição das unidades em subsuperfície}

Os dados de subsuperfície, referentes à distribuição das formações Botucatu e Pirambóia em poços tubulares de captação de água e de propecção de petróleo, permitiram a elaboração de mapas de contorno estrutural e mapa de isópacas das unidades e do Aqüífero Guarani no Estado de São Paulo.

No mapa de contorno estrutural do aqüífero, é possível identificar mergulho das unidades para $W$, no sentido da calha do rio Paraná, defletindo para SW, no sentido do Pontal do Paranapanema, onde estão as maiores profundidades de soterramento, de até $1900 \mathrm{~m}$ abaixo da superfície e $-1500 \mathrm{~m}$ de altitude (Figura 7.1 e 7.3). O mapa de contorno estrutural do topo da Formação Pirambóia mostra o posicionamento da superfície discordante que delimita esta unidade com a Formação Botucatu, superior. Esta superfície discordante apresenta também mergulho para W e SW, com altitudes de até quase $1650 \mathrm{~m}$ abaixo do nível do mar, na região do Pontal do Paranapanema (Figura 7.2).

As maiores espessuras da Formação Botucatu foram identificadas no poço de Lins (04-LI-02-SP), com 238 m. Como não foi possível revisar as amostras de calha 
e respectivos perfis dos poços de Presidente Epitácio, Três Lagoas e Cuiabá Paulista, não se dispõe de informações sobre a espessura de cada formação segundo o modelo genético dos sistemas eólicos Pirambóia e Botucatu. Assim, não é possível confirmar ou não o espessamento das unidades em direção à porção sudeste de Mato Grosso do Sul, descrito por Araújo et al. (1999). Segundo os dados disponíveis, as isópacas da Formação Botucatu apresentam as maiores espessuras no centro-oeste do Estado de São Paulo (Figura 7.4), configurando depocentro alongado na direção $\mathrm{NE}$, aproximadamente a mesma direção dos paleoventos predominantes da unidade na porção setentrional da Bacia do Paraná.

São poucos os dados de espessura da Formação Pirambóia, uma vez que somente 18 poços para captação de água atravessaram totalmente esta unidade. A maior espessura desta formação foi reconhecida no poço de Olímpia, com 270 m, e a menor em Paraguaçu Paulista, com 75 m. Esta distribuição demonstra possível adelgaçamento da unidade de NE para SW, em direção ao Estado do Paraná. No mapa de superfície de tendência das isópacas da Formação Pirambóia é possível observar que a zona de maior adelgaçamento, no centro-oeste do estado (Figura 7.5), coincide aproximadamente com o depocentro da Formação Botucatu. Esta configuração possivelmente reflete uma superfície de erosão previamente esculpida no topo da Formação Pirambóia, anteriormente à instalação do sistema eólico seco Botucatu.

Os dados de espessura da porção superior da Formação Pirambóia, de contexto flúvio-eólico, são também de distribuição heterogênea no aqüífero, apesar de haver mais dados disponíveis deste intervalo (53 poços) do que da Formação Pirambóia como um todo. A espessura média do intervalo flúvio-eólico, da porção superior da Formação Pirambóia, é de 35 m, com máxima espessura de $164 \mathrm{~m}$ identificada no poço de Guariba, situado em condições de pequeno confinamento (até $500 \mathrm{~m}$ de profundidade). O mapa de superfície de tendência das isópacas do topo da Formação Pirambóia (Figura 7.6) permite delinear um possível depocentro de direção NW, grosso modo concordante com o provável paleodeclive do sítio deposicional, uma vez que as direções de paleocorrentes do sistema fluvial entrelaçado, na zona de afloramento, são voltadas também para oeste (SW e NW), segundo Giannini et al. (2004). 


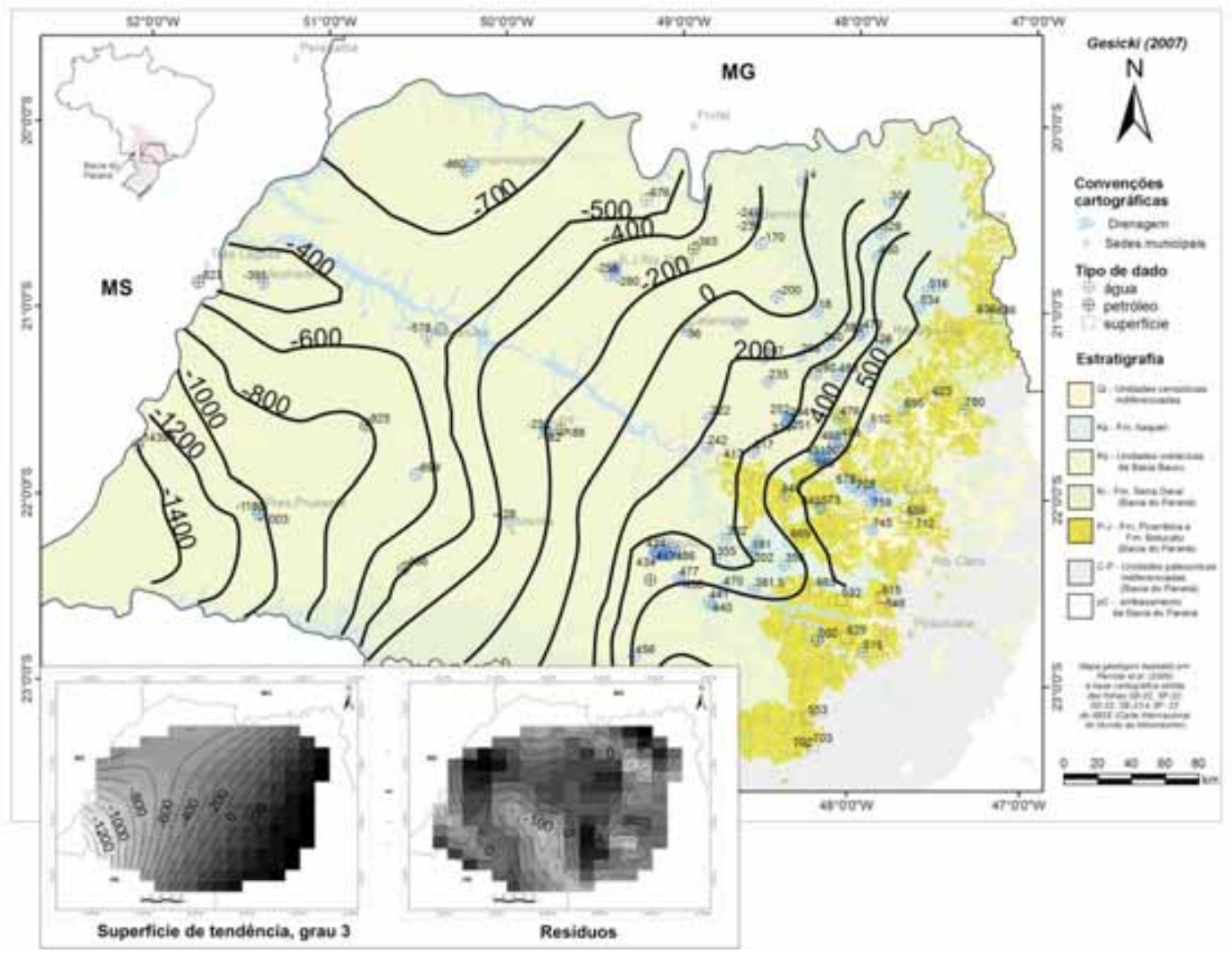

Figura 7.1 - Mapa de contorno estrutural do topo da Formação Botucatu em São Paulo. Isóbatas expressas em metros.

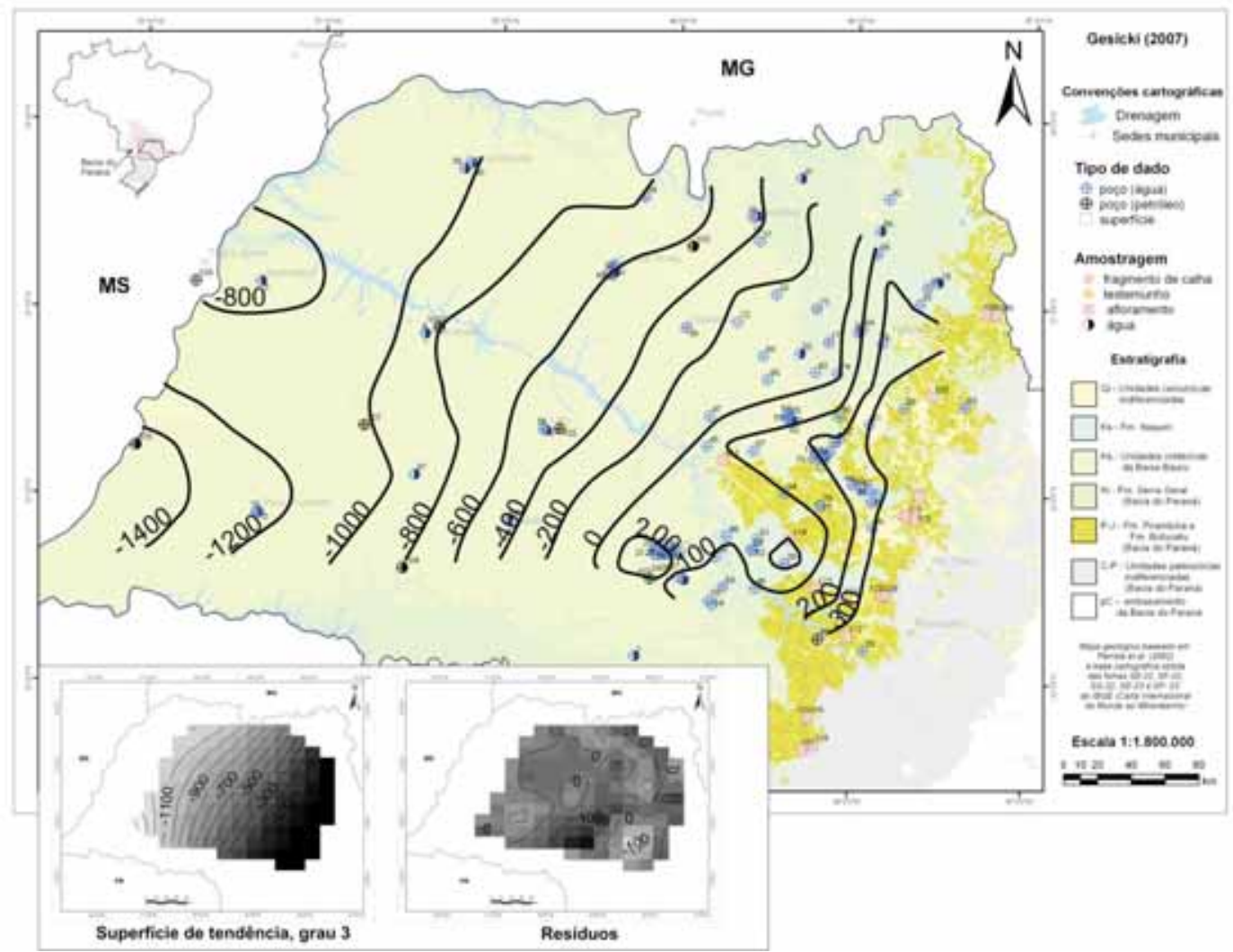

Figura 7.2 - Mapa de contorno estrutural do topo da Formação Pirambóia em São Paulo. Isóbatas expressas em metros. 


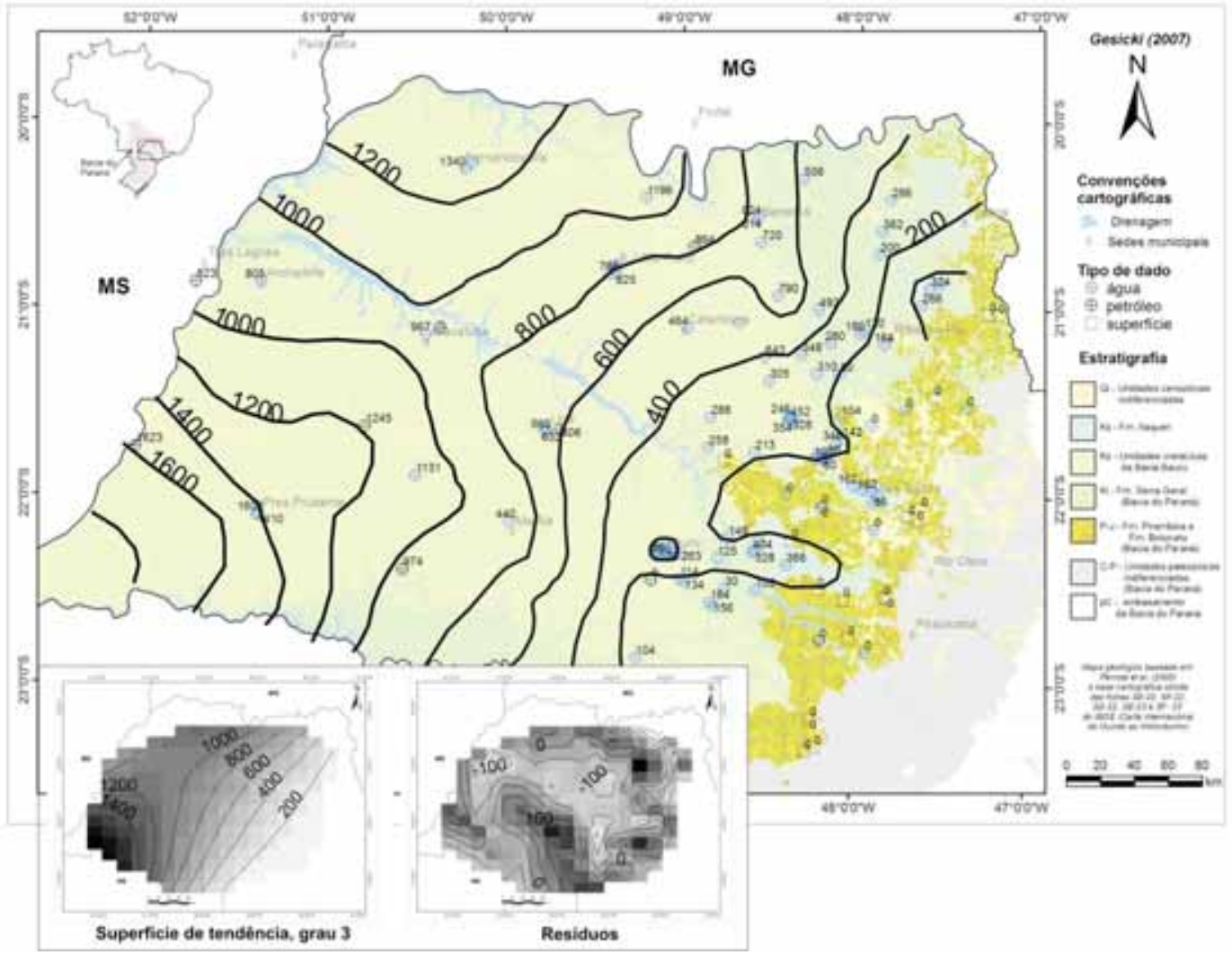

Figura 7.3 - Mapa de isópacas das rochas que encobrem as formações Pirambóia e Botucatu em São Paulo.

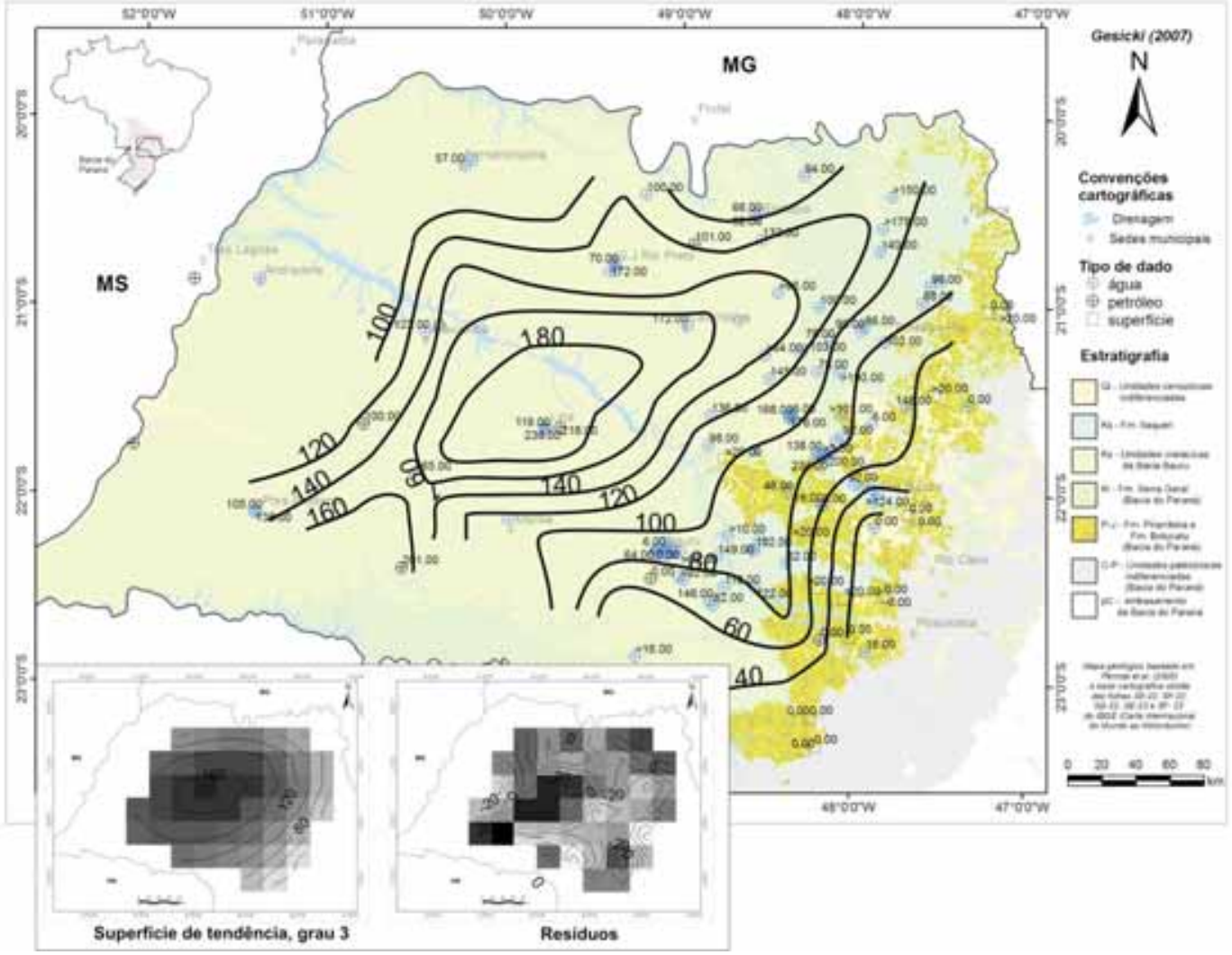

Figura 7.4 - Mapa de isópacas da Formação Botucatu em São Paulo. 


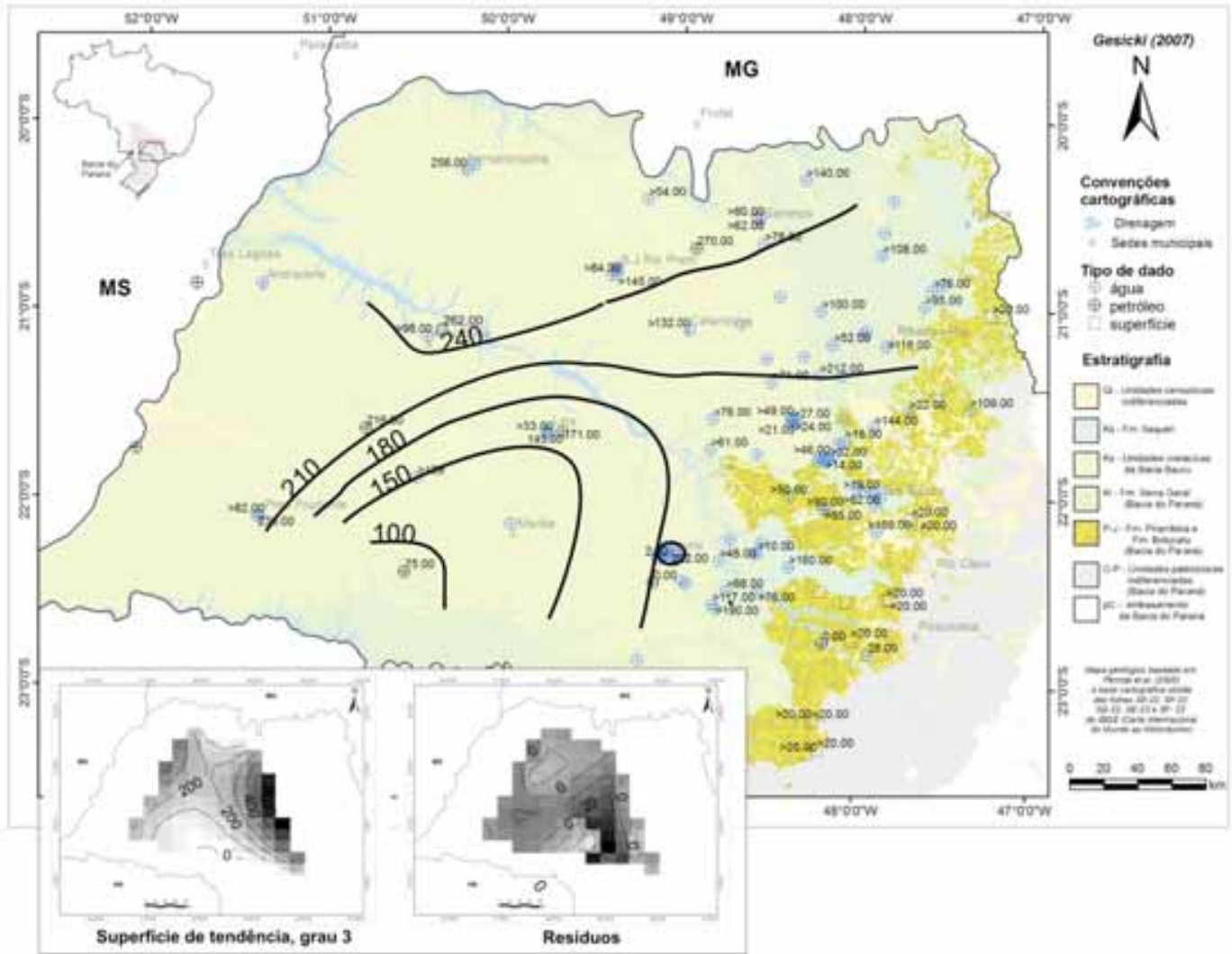

Figura 7.5 - Mapa de isópacas da Formação Pirambóia em São Paulo.

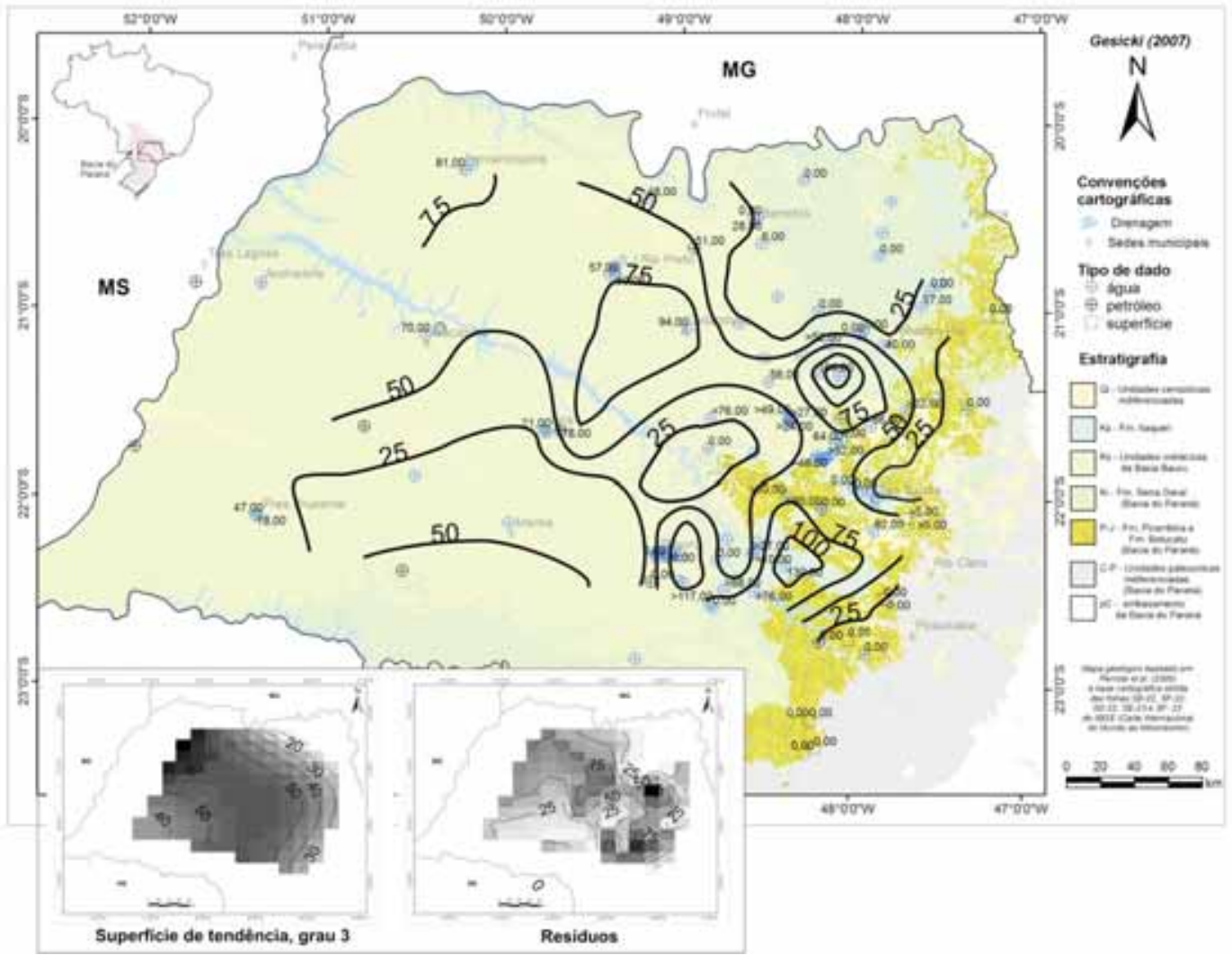

Figura 7.6 - Mapa de isópacas da porção superior da Formação Pirambóia em São Paulo. 
Os mapas de resíduos de superfícies de tendência das isóbatas de topo de Formação Botucatu e das espessuras das unidades que a encobrem são semelhantes e nota-se influência de estruturas de direção NW, provavelmente referentes à tectônica pós-deposicional. O mapa de resíduos das isóbatas de topo da Formação Pirambóia permite inferir sobre o controle das estruturas de direção NE modificando a superfície deposicional desta unidade. 


\section{O SISTEMA AQUÍFERO GUARANI (SAG) EM SP}

O Sistema Aqüífero Guarani (SAG) no Estado de São Paulo é delimitado na base e no topo por dois aquitardes, respectivamente, as rochas pelíticas permianas do Grupo Passa Dois (formações Corumbataí/Teresina/Rio do Rasto) e as rochas vulcânicas cretácicas da Formação Serra Geral. Apesar de constituir regionalmente um importante aqüífero fraturado, a Formação Serra Geral impõe condições de confinamento profundo ao conjunto sedimentar arenoso pré-vulcânico, o que determina o artesianismo do SAG em boa parte do oeste paulista.

As áreas de recarga direta do SAG no Estado de São Paulo situam-se a leste, ao longo da faixa de afloramento das formações Pirambóia e Botucatu, com padrão geral de fluxo subterrâneo de leste para oeste, em direção à calha do rio Paraná, acompanhando o mergulho regional daquelas unidades estratigráficas bacia adentro (Silva 1983). O mapa potenciométrico da figura 8.1 apresenta o padrão geral de fluxo subterrâneo do SAG.

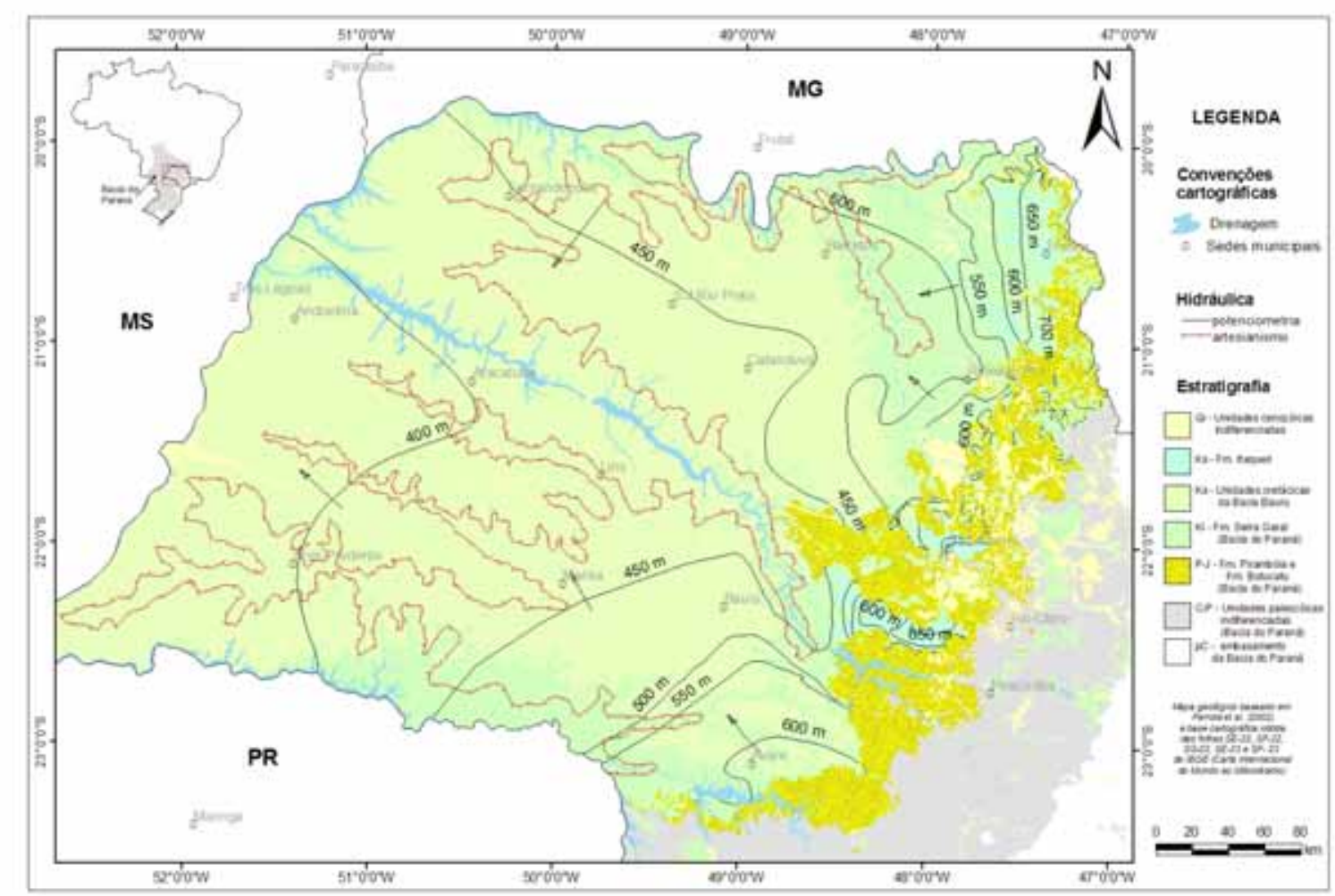

Figura 8.1 - Mapa potenciométrico do SAG no Estado de São Paulo. Baseado em Takahashi (2005). 
As características e a evolução hidroquímica das águas subterrâneas e o padrão de fluxo deste sistema aqüífero, inicialmente denominado Aqüífero Botucatu, foram estabelecidas em caráter pioneiro nos trabalhos de Silva (1983) e Rebouças (1976), cujos dados embasaram vários estudos hidrogeológicos posteriores. A primeira autora reconheceu que as águas subterrâneas apresentam teores salinos muito baixos (resíduo seco médio inferior a $300 \mathrm{mg} / \mathrm{l}$ ), os quais, ao longo do percurso subterrâneo, são enriquecidos e modificados no sentido das áreas de maior confinamento. Em termos gerais, ao longo da área de recarga (porção livre do aqüífero) e de confinamento pouco profundo (faixa marginal de cerca de 60 km de largura sob a Formação Serra Geral), as águas subterrâneas são bicarbonatadas magnesianas e cálcio-magnesianas, com temperaturas da ordem de $25^{\circ}$ a $30^{\circ} \mathrm{C}$, tornando-se bicarbonatadas sódicas e evoluindo para cloro-sulfatadas sódicas no extremo sudoeste do estado, já sob condições de profundo confinamento, onde as temperaturas atingem até $63^{\circ} \mathrm{C}$.

O gradiente hidráulico médio do SAG é de cerca de $1 \mathrm{~m} / \mathrm{km}$, com valores médios de condutividade hidráulica $(\mathrm{K})$ de $1,5 \times 10^{-4} \mathrm{~m} / \mathrm{s}$ e de transmissividade ( $\mathrm{T}$ ) de $3,9 \times 10^{-3} \mathrm{~m}^{2} / \mathrm{s}$ (Silva 1983, Sracek \& Hirata 2002). No Estado de São Paulo, a velocidade média da água subterrânea gira ao redor de 27 m/ano, admitida uma porosidade efetiva média de 12\% (Silva 1983, Sracek \& Hirata 2002). Estas características hidráulicas indicam que o aqüífero apresenta baixa velocidade de fluxo e, portanto, pequeno potencial de renovação de água. Convém ressaltar que Hirata et al. (1999) estabeleceram para o SAG, ao longo da faixa aflorante das formações Pirambóia e Botucatu, um dos índices de mais alto risco de poluição dentre os aqüíferos do Estado de São Paulo.

O uso de técnicas isotópicas (isótopos de ${ }^{18} \mathrm{O}, \mathrm{D}$ e ${ }^{14} \mathrm{C}$ ) e a análise química de águas subterrâneas permitem o estabelecimento de padrões de fluxo hidroquímico, o reconhecimento das idades das águas e os mecanismos de evolução hidrogeoquímica do sistema aqüífero. No caso do SAG no Estado de São Paulo, destacam-se, neste tema, os trabalhos de Silva (1983), Fraga (1992), Campos (1993), Meng \& Maynard (2001) e Sracek \& Hirata (2002). Relações entre a idade e as características geoquímicas das águas subterrâneas foram reconhecidas pioneiramente por Silva (1983). Para esta autora, as águas seriam progressivamente mais antigas e salinas no oeste do estado, apresentando idades $\left({ }^{14} \mathrm{C}\right)$ superiores a 30.000 anos nas áreas de mais profundo confinamento do aqüífero. 
Em vista dessas evidências de fluxo hidráulico lento e da presença de águas muito antigas no oeste do estado, Silva (1983) interpretou que o tempo de residência da água seria cada vez maior no sentido das zonas de maior confinamento do aqǘfero, o que influenciaria o aumento da salinidade devido ao maior tempo de reação entre a água e a rocha. Neste contexto, reforçado ainda por condições de $\mathrm{pH}$ progressivamente mais alcalino e temperaturas altas nas zonas mais internas do SAG, Silva (1983) interpretou variações hidroquímicas do aqüífero relacionadas à dissolução mineral na porção livre do aqüífero e de confinamento pouco profundo e à precipitação de carbonatos na zona de confinamento profundo.

Meng \& Maynard (2001) fizeram uso de técnicas de tratamento estatístico multivariado e de modelamento geoquímico numérico de dados químicos e aprimoraram as interpretações sobre a evolução química do SAG, utilizando os dados de Silva (1983) no Estado de São Paulo. O modelo geoquímico conceitual desenvolvido por estes autores permitiu a individualização de três regiões geoquímicas distintas no SAG: 1- área de recarga, onde predominam altas concentrações de sílica dissolvida em água; 2- zona intermediária (porção confinada do aqǘfero até cerca de $200 \mathrm{~km}$ além da área de recarga), caracterizada por predomínio de íons bicarbonato, e 3- interior da bacia, que apresenta águas mais salinas, ricas em íons dissolvidos de sódio, cloreto e sulfato. Meng \& Maynard (2001) reconheceram também que as áreas de recarga seriam zonas de ativa dissolução mineral, principalmente de feldspato alcalino; na zona intermediária, haveria tanto dissolução quanto precipitação, respectivamente, de cimento carbonático e de sílica; o interior da bacia, por sua vez, teria o predomínio de precipitação de carbonatos, onde as águas salinas seriam provenientes principalmente das formações subjacentes (Grupo Passa Dois).

Sracek \& Hirata (2002) delinearam evolução geoquímica para o SAG no Estado de São Paulo, também baseada nos dados de Silva (1983), utilizando-se exclusivamente de modelamento geoquímico numérico de dados químicos e isotópicos. Para estes autores, além da dissolução de cimento de carbonatos, existiria um importante papel da troca catiônica entre água e rocha na evolução hidrogeoquímica do aqüífero. A perda de cálcio dissolvido nas águas ocorreria basicamente por substituição pelo sódio, o que explica as águas sódiobicarbonatadas nas porções mais confinadas do aqüífero. Esta frente de troca catiônica, segundo os autores, move-se, em direção aos gradientes hidráulicos maiores, numa razão muito menor que a velocidade de fluxo da água subterrânea. 
Estes autores acreditam que o carbonato solubilizado seja proveniente principalmente do cimento calcítico reconhecido por Caetano-Chang (1997) nos arenitos da Formação Pirambóia. Outra importante frente de troca catiônica seria a substituição de íons sulfato $\left(\mathrm{SO}_{4}^{-2}\right)$ por íons cloreto $\left(\mathrm{Cl}^{-}\right)$, ambos relacionados provavelmente à dissolução de evaporitos (gipso, halita e mirabilita) da Formação Pirambóia, que os autores supõem existir pelo caráter árido da sedimentação desta unidade.

Cabe destacar, ainda, o trabalho de Araújo et al. (1999), que apresenta modelo de evolução geológica e hidrogeológica do SAG desde a deposição das unidades Pirambóia e Botucatu. Estes autores acreditam que a história sedimentar e pós-sedimentar destas formações fornece indícios de que as condições geoquímicas do sistema aqüífero após o confinamento sob os vulcanitos Serra Geral, seriam de águas salobras ou pouco salinas, como herança do paleoclima predominantemente árido durante e após a sedimentação. Segundo tal concepção, com o soerguimento e rejuvenescimento da serra do Mar, no Cretáceo Médio e Terciário, respectivamente, com conseqüente criação de gradiente hidráulico no aqüífero, teriam sido instaladas condições para o intenso influxo de águas meteóricas durante o Quaternário, a partir das áreas aflorantes, a leste.

\subsection{Dados hidrogeoquímicos e isotópicos}

Amostras de água subterrânea foram coletadas de 26 poços de captação de água e abastecimento público no interior do estado, e foram analisadas quanto à composição química e parâmetros físico-químicos. Os principais resultados analíticos encontram-se sumarizados no trabalho de Portugal (2006). No Quadro 8.1 , estão relacionados os locais de amostragem de água do SAG.

Com relação à composição e classificação química das águas do SAG, foi observada, a partir destes novos dados, a mesma tendência de variação da composição química e dos parâmetros físico-químicos reportados por Silva (1983). As águas do aqüífero são muito diluídas na zona de recarga, que corresponde à faixa de afloramento das formações Pirambóia e Botucatu, tornam-se bicabonatadas, ricas em cálcio e magnésio na zona de pequeno confinamento, e adquirem características cloro-sulfatadas, ricas em sódio, em direção ao oeste/sudoeste do estado, sob condição de profundo confinamento. 
O trabalho de Portugal (2006) contém abordagem mais abrangente que a de Silva (1983), baseada na obtenção de uma série de resultados analíticos, incluindo: mapas de contorno de isoconcentrações dos principais cátions e ânions dissolvidos; cálculo de índices hidroquímicos, segundo proposta de Hounslow (1995); avaliação teórica de diagramas de estabilidade dos minerais da rocha em relação à composição da água e modelamento hidroquímico, com cálculo teórico de índices de saturação de minerais, utilizando-se o programa PHREEQC (Parkhust 1995). A discussão destes resultados será feita adiante.

Quadro 8.1 - Relação dos poços de amostragem de água (Portugal 2006).

\begin{tabular}{|c|c|c|c|}
\hline Código & Localidade & Profundidade total & Formações perfuradas \\
\hline ADD & Andradina & $940 \mathrm{~m}$ & BOT/PIR \\
\hline AGU & Agudos & $183 \mathrm{~m}$ & BOT \\
\hline ARÇ & Araçatuba & $1200 \mathrm{~m}$ & BOT/PIR \\
\hline BAR & Barretos & $1014 \mathrm{~m}$ & BOT/PIR \\
\hline BAT & Batatais & $265 \mathrm{~m}$ & BOT/PIR \\
\hline BAU 1 & Bauru & $310 \mathrm{~m}$ & BOT/PIR* \\
\hline BAU 2 & Bauru & $473 \mathrm{~m}$ & BOT/PIR* \\
\hline CAS & Cassilândia - MS & $215 \mathrm{~m}$ & BOT \\
\hline EPI & Presidente Epitácio & $3950 \mathrm{~m}$ & BOT/PIR* \\
\hline FER 2 & Fernandópolis & $1680 \mathrm{~m}$ & BOT/PIR* \\
\hline FER 3 & Fernandópolis & $1604 \mathrm{~m}$ & BOT/PIR* \\
\hline GUA & Guaíra & $740 \mathrm{~m}$ & BOT/PIR \\
\hline JAB & Jaboticabal & $456 \mathrm{~m}$ & BOT \\
\hline LIN & Lins & $1042 \mathrm{~m}$ & BOT/PIR* \\
\hline MAT & Matão & $580 \mathrm{~m}$ & BOT/PIR \\
\hline MRL & Marília & $1228 \mathrm{~m}$ & BOT/PIR \\
\hline OLI & Olímpia & $2568 \mathrm{~m}$ & BOT/PIR* \\
\hline PGU & Paraguaçu Paulista & $3663 \mathrm{~m}$ & BOT/PIR* \\
\hline PRU & Presidente Prudente & $1975 \mathrm{~m}$ & BOT/PIR* \\
\hline SBB & Águas de Santa Bárbara & $340 \mathrm{~m}$ & BOT \\
\hline SER & Sertãozinho & $408 \mathrm{~m}$ & BOT/PIR \\
\hline SJB & São Joaquim da Barra & $588 \mathrm{~m}$ & BOT \\
\hline SRP & São José do Rio Preto & $1152 \mathrm{~m}$ & BOT/PIR \\
\hline TIM & Timburi & $181 \mathrm{~m}$ & BOT \\
\hline TUP & Tupã & $1479 \mathrm{~m}$ & BOT/PIR \\
\hline
\end{tabular}

A temperatura das águas, a condutividade elétrica e o $\mathrm{pH}$ apresentam, respectivamente, a seguinte faixa de variação de leste para sudoeste do aqüífero: $22^{\circ} \mathrm{C}$ a $66^{\circ} \mathrm{C} ; 41$ a $1425 \mu \mathrm{S} / \mathrm{cm}$; e de 5,6 a 10 . Os teores de bicarbonato e carbonato dissolvidos são muito baixos na zona de pequeno confinamento, da ordem de 26 mg/L (poço Batatais), crescendo para cerca de 100 a 200 mg/L na 
porção intermediária, até atingir os teores acima de $300 \mathrm{mg} / \mathrm{L}$ nas zonas mais profundas do aqüífero (poços Adamantina e Presidente Prudente).

As concentrações de cálcio e magnésio, de um lado, e de sódio, sulfato e cloro, de outro, apresentam distribuições antagônicas (figura 8.2). Os maiores valores de cálcio e magnésio encontam-se em poços próximos à borda leste do aqüífero, com valores máximos no poço de Matão ( $41 \mathrm{mg} / \mathrm{L}$ e 4,6 mg/L). No centro e oeste do estado, cálcio e magnésio juntos não ultrapassam $2 \mathrm{mg} / \mathrm{L}$ de água. Com relação aos ânions sulfato e cloreto, as concentrações aumentam abruptamente, de valores menores que $10 \mathrm{mg} / \mathrm{L}$, a leste, para valores acima dos $100 \mathrm{mg} / \mathrm{L}$, no oeste do aqüífero. Comportamento semelhante é verificado em relação ao sódio, com concentrações máximas de 308 mg/L no poço de Presidente Prudente.

A relação inversa da distribuição das concentrações de cálcio e sódio pode ser explicada pela troca catiônica do primeiro (em solução na água) pelo segundo (adsorvido na rocha), conforme propuseram Sracek \& Hirata (2002). Este processo pode ser também avaliado através de índices hidroquímicos, como as relações $\mathrm{Ca} /\left(\mathrm{Ca}+\mathrm{SO}_{4}\right)$ e $\mathrm{SiO}_{2} /(\mathrm{Na}+\mathrm{K}-\mathrm{Cl})$. No primeiro caso, valores acima de 0,5 indicam excesso de cálcio na água e valores menores que 0,5 indicam que este cátion está sendo retirado dela por precipitação ou por troca catiônica. De forma semelhante, na relação entre sílica e sódio + potássio, valores maiores que 1 indicam fonte suplementar de íons alcalinos na água (por exemplo da alteração de feldspatos e micas) e valores menores que 1 indicam que estes íons estão sendo dela retirados.

Comparando-se as figuras 8.2 e 8.3, percebe-se que nas zonas de afloramento e de pequeno confinamento do aqüífero (até $500 \mathrm{~m}$ de profundidade) há disponibilidade tanto de cálcio quanto de sódio e sílica dissolvidos. Nesta região, as águas são mais agressivas e tendem a dissolver minerais instáveis do arcabouço rochoso, permitindo a maior disponibilidade destes íons na água. Na zona de médio confinamento (500 a 1000 m de profundidade), nota-se uma nítida fronteira a partir da qual o cálcio é retirado da água, entre os poços de São Joaquim da Barra e Barretos, no norte do estado, e entre Bauru e Marília, no sul. 

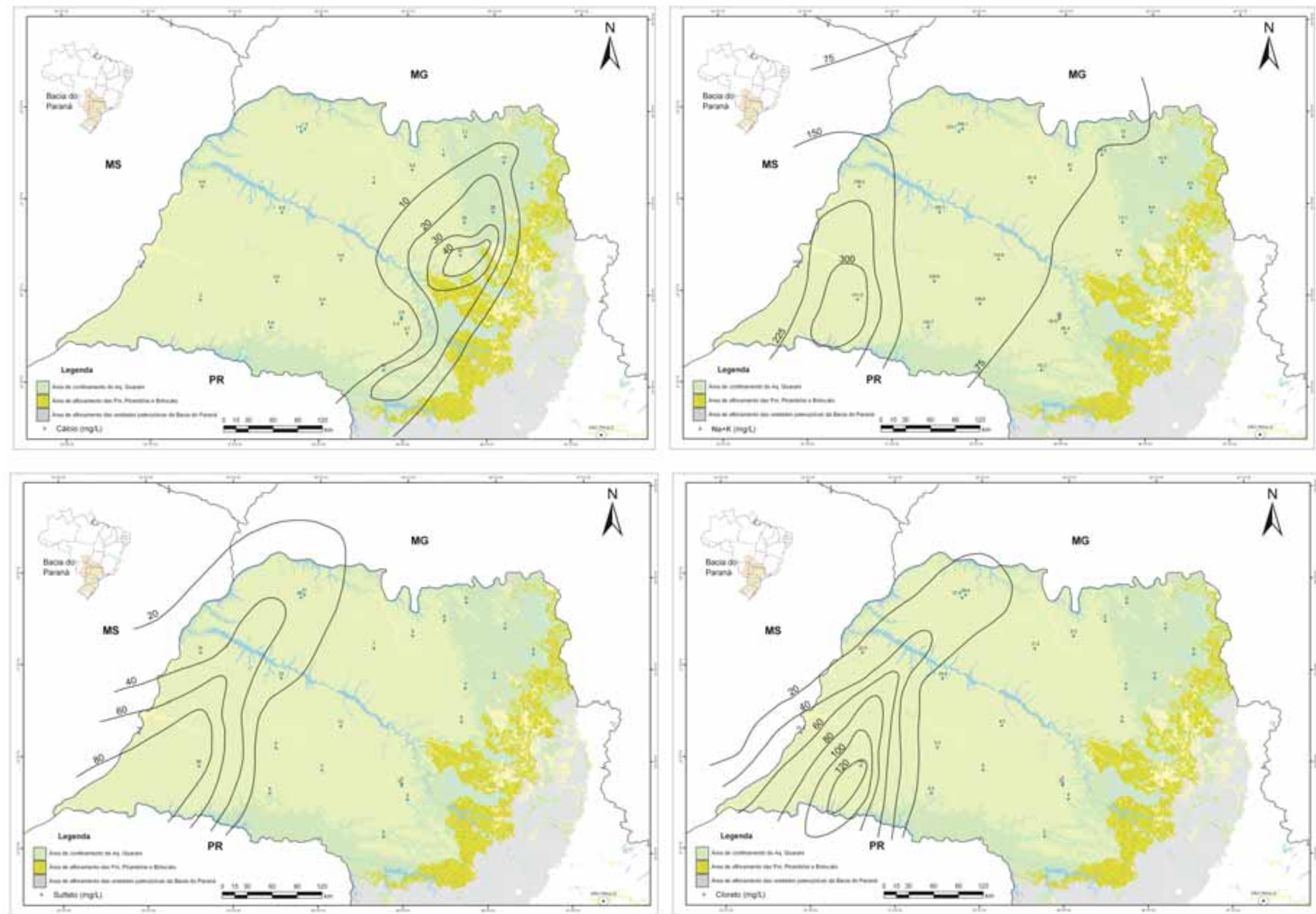

Figura 8.2 - Mapas de isoconcentrações de cálcio, sódio + potássio, sulfato e cloreto do SAG em São Paulo. Extraídos de Portugal (2006). 

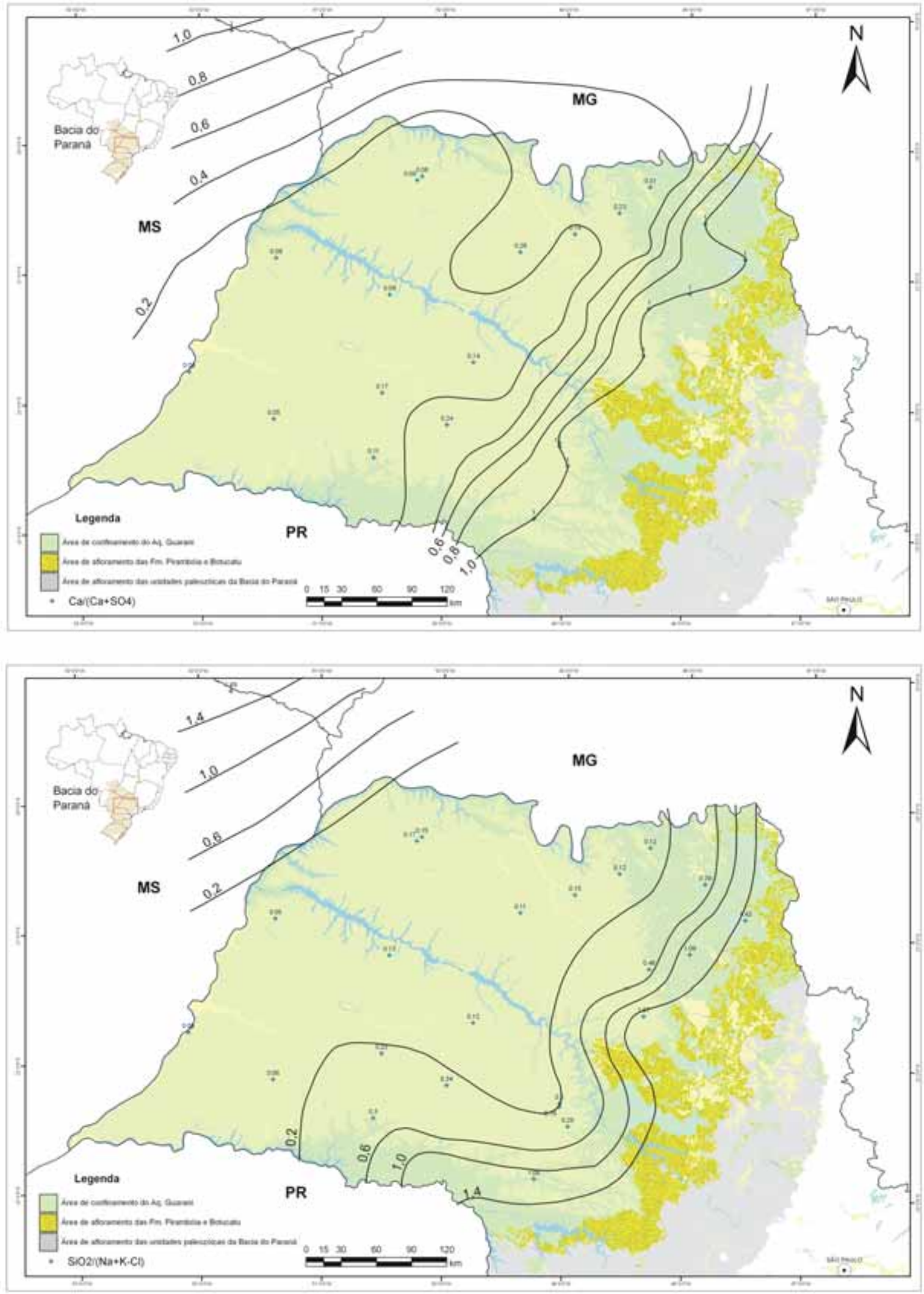

Figura 8.3 - Mapas de distribuição dos índices hidroquímicos $\mathrm{Ca} /\left(\mathrm{Ca}+\mathrm{SO}_{4}\right)$ e $\mathrm{SiO}_{2} /(\mathrm{Na}+\mathrm{K}$ - Cl). Extraídos de Portugal (2006). 
A retirada de cálcio da água pode também ocorrer pela precipitação de cimento de calcita na rocha, no entanto este processo aparentemente não é o principal mecanismo de remoção deste cátion. A relação entre as concentrações de bicarbonato e de sílica e a avaliação do índice de saturação da calcita na água (figura 8.4) demonstram que a faixa marginal do aquífero apresenta excesso de sílica dissolvida, com índices de saturação negativos com relação à calcita. No restante do aquífero, a água encontra-se em equilíbrio com este mineral, e pode estar havendo tanto a sua precipitação quanto dissolução. Somente nos poços de profundo confinamento, no extremo oeste do estado (poços de Andradina, Presidente Prudente e Presidente Epitácio), é que se verifica excesso de bicarbonato, indicativo de efetiva precipitação de calcita.

A porção centro-sul do aqüífero, balizada pelos poços de Paraguaçu Paulista, Marília e Tupã, apresenta excesso de sílica dissolvida na água. Esta é uma característica anômala para poços em condições de confinamento médio a profundo. Nestes poços, apesar das concetrações relativamente altas de bicarbonato (240 a $290 \mathrm{mg} / \mathrm{L}$ ), os valores de índice de saturação da calcita são negativos $(-0,08$ a $-0,19)$ e indicativos de tendência de dissolução deste mineral, ao invés da sua precipitação. É possível que a disponibilidade de sílica dissolvida esteja associada às condições de acentuada alcalinidade da água, visto que nesta porção do aqüífero foram encontrados os valores mais altos de $\mathrm{pH}$ medidos $(\mathrm{pH}=10$ no poço de Marília).

No trabalho de Portugal (2006), foram lançados dados químicos do SAG em diagramas de estabilidade de aluminossilicatos (figura 8.5), de forma a auxiliar na interpretação das fases minerais em equilíbrio com a água e para identificar variações específicas ao longo das zonas de confinameno do aqüífero. Segundo estes diagramas, foi possível identificar que a composição das águas de poços da zona de pequeno confinamento, como Batatais e Timburi, encontra-se dentro do campo de estabilidade da caulinita e do quartzo. Nos outros poços do aquífero, as águas em geral encontram-se em equilíbrio com a montmorillonita (esmectita), com o microclínio e com a muscovita. 

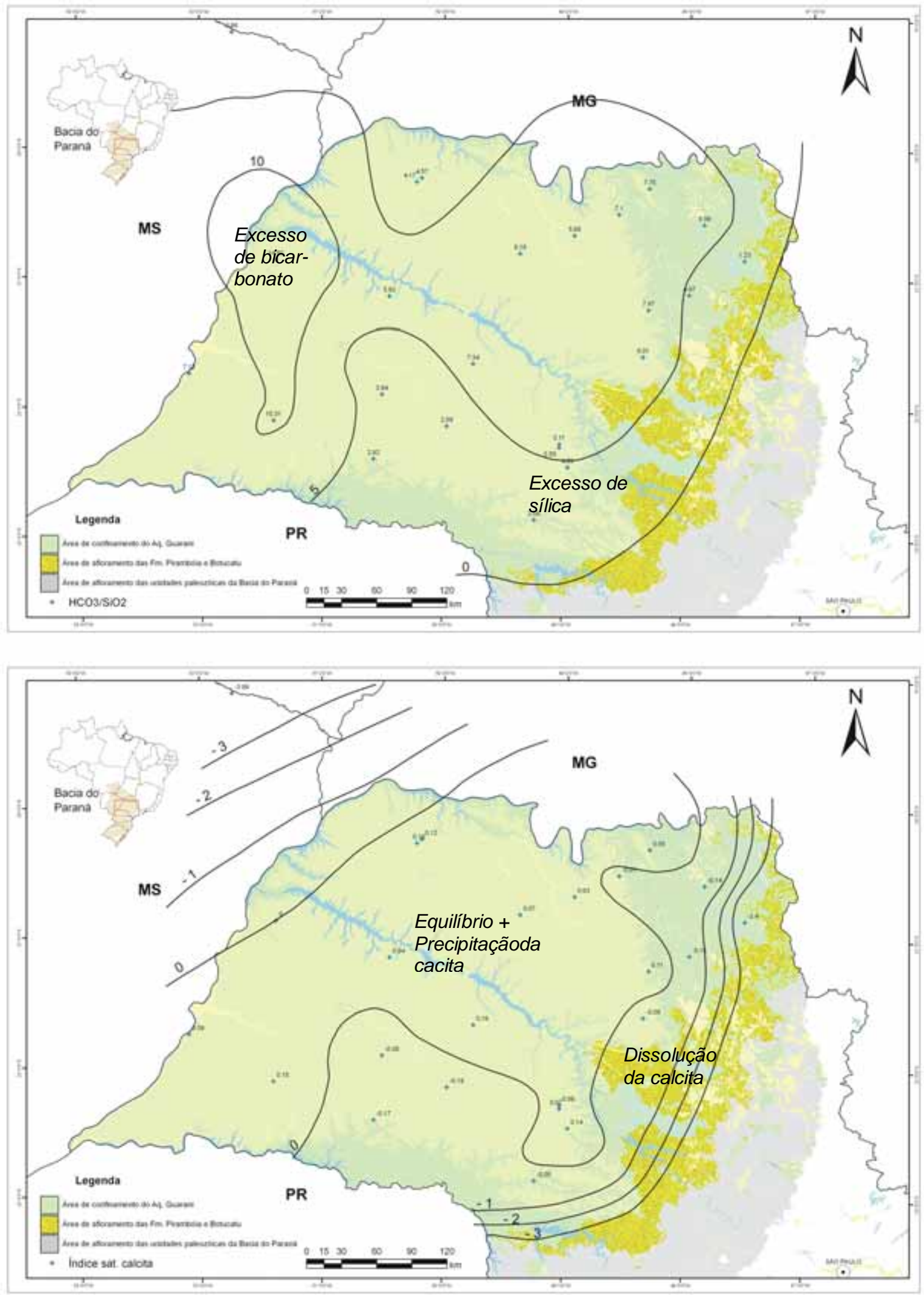

Figura 8.4 - Mapas de distribuição dos valores da razão entre bicarbonato e sílica e do índice de saturação teórico da calcita na água. Extraído de Portugal (2006). 

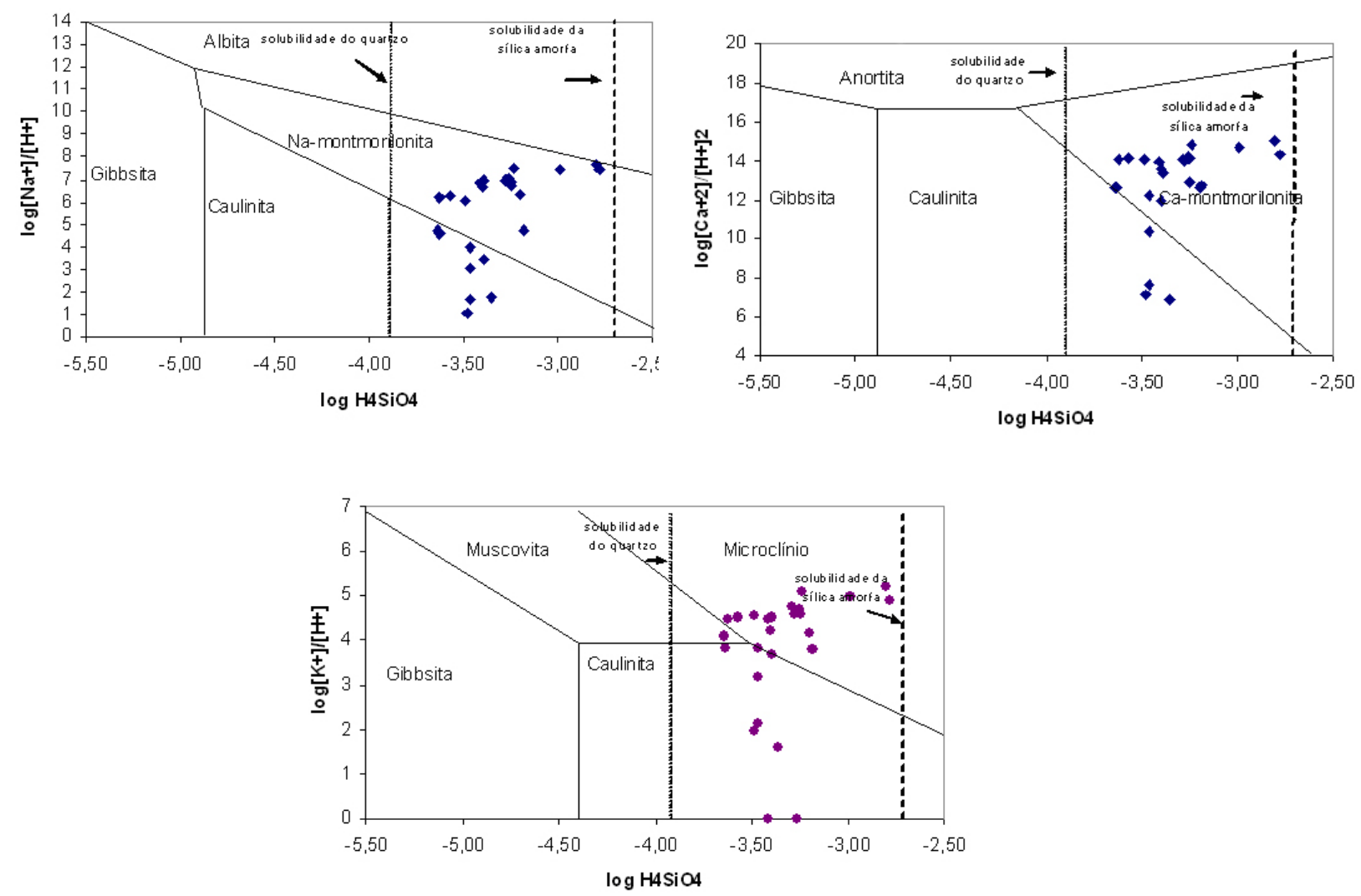

Figura 8.5 - Diagramas de estabilidade de aluminossilicatos, em relação à concentração de cálcio, sódio e potássio da água. Extraído de Portugal (2006).

As idades aparentes das águas do SAG variam de 2380 a 27660 anos AP (datação ${ }^{14} \mathrm{C}$ ), com valores crescentes de leste para oeste do aqüífero (figura 8.6), coerentes com o sentido geral do fluxo subterrâneo (Portugal 2006). A faixa de águas jovens, de até 10.000 anos, corresponde aos poços da zona de pequeno confinamento, como Timburi, Águas de Santa Bárbara, Matão, Sertãozinho e Batatais. Águas com idades entre 10.000 e 20.000 estão situadas na zona de confinamento médio a profundo, como Jaboticabal, Guaíra, Barretos, Fernandópolis e São José do Rio Preto. Acima de 20.000 anos, situam-se as águas dos poços profundos como Marília, Lins, Presidente Epitácio e Adamantina. 


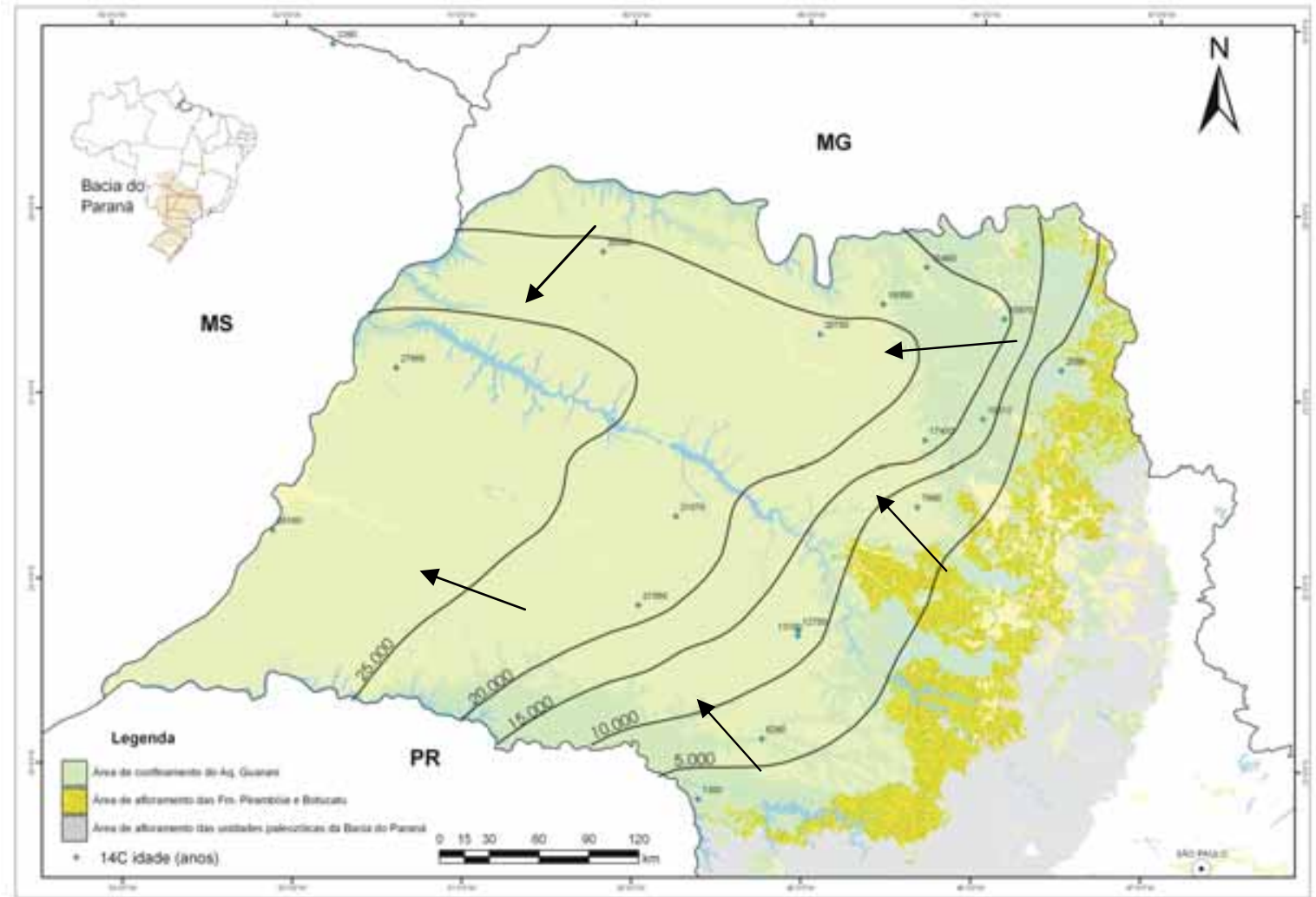

Figura 8.6 - Mapa de isócronas do SAG, baseadas em datação ${ }^{14} \mathrm{C}$. Extraído de Portugal (2006). As setas indicam o sentido de fluxo advectivo do aqüífero.

As águas da porção nordeste do aqüífero em São Paulo são relativamente antigas, na faixa dos 15000 a 20000 anos, mesmo em condições de relativa proximidade com a zona de afloramento, como os poços de Jaboticabal e São Joaquim da Barra. Esta característica é contraditória com a velocidade teórica de fluxo subterrâneo nesta região, que apresenta grandiente hidráulico relativamente maior se comparado com a porção equivalente do aqüífero ao sul do rio Tietê. Silva (1983) já havia chamado a atenção para o fato de, na porção nordeste do estado, o fluxo subterrâneo poder ser retardado pela presença marcante de sills e diques de diabásios.

No noroeste do aqüífero, balizado pelo poço de Fernandópolis, as águas não são tão velhas (20.000 anos) se considerada sua condição de confinamento profundo em comparação aos poços de Andradina e Presidente Prudente ( $>25.000$ anos). Nesta região, o sentido de fluxo subterrâneo para SW demonstra que as águas não são provenientes da zona de afloramentos das formações Pirambóia e Botucatu, a leste, mas sim do Triângulo Mineiro, ao norte. 
Gastmans \& Chang (2005) apontaram a zona aflorante das unidades Pirambóia e Botucatu em Mato Grosso e Goiás como a principal área de recarga do SAG setentrional (figura 8.7). Segundo estes autores, o padrão de fluxo subterrâneo em Mato Grosso do Sul seria primordialmente de NNE para SSW, na porção confinada do aqüífero, no leste do estado, e de SE para NW na borda da cuesta basáltica (serra de Maracaju). Assim, o padrão de fluxo subterrâneo naquele estado, na zona de pequeno confinamento, seria o oposto do padrão de fluxo do SAG paulista, com as áreas de afloramento das formações Pirambóia e Botucatu constituindo área de descarga do aqüífero. Segundo esta configuração, Gastmans \& Chang (2005) definiram um divisor do SAG, de direção NE, situado a leste de Campo Grande, que estaria condicionando a direção de fluxo subterrâneo paralelamente à calha do rio Paraná em grande parte do leste sul-matogrossense.

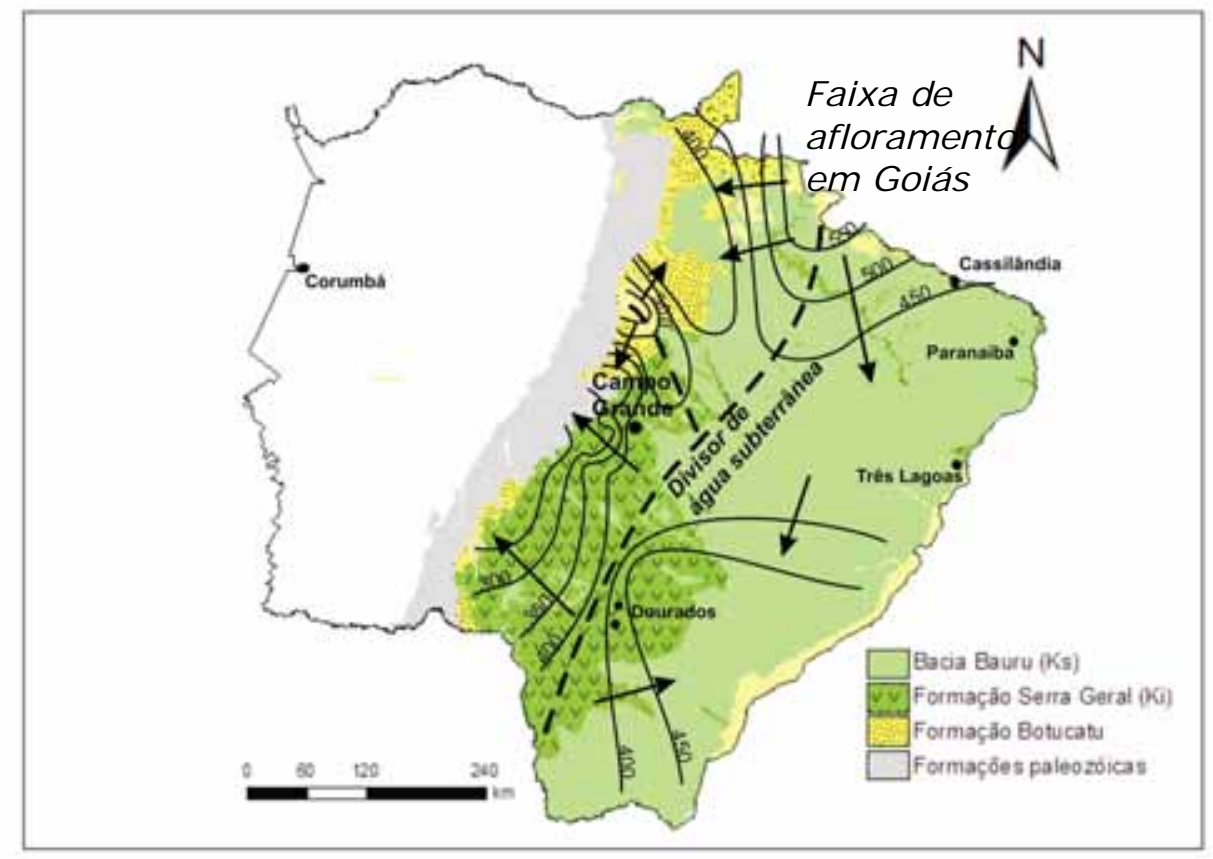

Figura 8.7 - Mapa potenciométrico do SAG em Mato Grosso do Sul, segundo proposta de Gastmans \& Chang (2005).

O padrão de fluxo subterrâneo diferenciado do aquífero em Mato Grosso do Sul e as áreas de recarga do extremo norte do SAG, em Goiás, aparentemente não influenciam o fluxo do aqüífero em Fernandópolis e no Triângulo Mineiro. Porém, não há informações na literatura sobre o comportamento hidráulico e a hidrogeoquímica do SAG em Minas Gerais, portanto pouco se pode inferir sobre a evolução da água subterrânea proveniente de norte/nordeste e a área de recarga do aqüífero naquele estado. Sabe-se somente que, no Estado de Minas Gerais, as 
formações Pirambóia e Botucatu são aflorantes numa estreita faixa na borda nordeste da Bacia do Paraná, na região do Arco da Canastra.

\subsection{Modelo hidrogeoquímico conceitual}

Segundo modelo proposto por Portugal (2006), o SAG pode ser subdividido em cinco áreas hidrogeoquímicas distintas no Estado de Sâo Paulo, além de uma área intermediária, balizada pela calha do rio Tietê, a qual delimita os domínos norte e sul do aquífero (Figura 8.8).

A Área I do SAG é representada pela porção de pequeno confinamento e de recarga do aqüífero, definida pelos poços de Timburi, Agudos, Bauru, Matão, Jaboticabal, Sertãozinho, Batatais e São Joaquim da Barra. As características da água nesta área são de baixas temperaturas $\left(<30^{\circ} \mathrm{C}\right)$, baixa condutividade elétrica ( $<260 \mu \mathrm{S} / \mathrm{cm}$ ) e valores variáveis de $\mathrm{pH}$ (6 a 9). Quimicamente, predominam águas com baixas concentrações de bicarbonato + carbonato ( $<150 \mathrm{mg} / \mathrm{L}$ ) e de sílica (14 a $26 \mathrm{mg} / \mathrm{L})$, mas com concentrações elevadas de cálcio e magnésio (respectivamente $>10 \mathrm{mg} / \mathrm{L}$ e $>1 \mathrm{mg} / \mathrm{L}$ ), as quais atingem valores anômalos no poço de Matão (respectivamente 41 e 4,6 mg/L). O índice de saturação da calcita é negativo nesta região, exceto nos poços de Bauru e Agudos, enquanto o índice de saturação da calcedônia é positivo na maior parte dos poços amostrados, exceto Matão.

A Área II do SAG situa-se no centro-sul paulista, região dos poços de Marília, Tupã e Paraguaçu Paulista. As principais características das águas nesta área são o alto valor de $\mathrm{pH}(>9,5)$ e o excesso de sílica dissolvida, com as concentrações mais elevadas do aqüífero (62 a $100 \mathrm{mg} / \mathrm{L}$ ). Os teores de sódio + potássio variam de 105 a $130 \mathrm{mg} / \mathrm{L}$ e de bicarbonato + carbonato encontram-se na faixa dos 240 a $300 \mathrm{mg} / \mathrm{L}$. A temperatura das águas varia de $43^{\circ}$ a $54^{\circ} \mathrm{C}$ e a condutividade elétrica apresenta valores entre 490 e $610 \mu \mathrm{S} / \mathrm{cm}$. As concetrações de cloreto, cálcio, magnésio e sulfato são baixas, em geral $<10$ mg/L.

A porção de maior confinamento do SAG, no sudeoste do estado, que compreende os poços de Presidente Prudente e Presidente Epitácio, foi definida como Área III por Portugal (2006). Nesta região situam-se as águas mais quentes $\left(55^{\circ}\right.$ a $67^{\circ} \mathrm{C}$ ) e mineralizadas do aqüífero (condutividade elétrica de 900 a 1300 $\mu \mathrm{S} / \mathrm{cm}$ ). São águas antigas (26.000 anos AP), com concentrações elevadas de bicarbonato + carbonato (275 e 356 mg/L), cloreto (54 e 130 mg/L), sódio + 
potássio (193 e $312 \mathrm{mg} / \mathrm{L}$ ) e de sufato (78 e $99 \mathrm{mg} / \mathrm{L}$ ). Existe excesso de bicarbonato dissolvido e os índices de saturação da calcita e da calcedônia são positivos ou próximos do equilíbrio. Os teores de cálcio e magnésio são baixos, em geral menores que $2 \mathrm{mg} / \mathrm{L}$.

A Área IV do SAG foi definida em função das características dos poços de Fernandópolis, situados na região noroeste do Estado de São Paulo. Nestes poços, as águas apresentam valores moderados a altos de temperatura $\left(55^{\circ} \mathrm{C}\right)$, condutividade elétrica (em média $530 \mu \mathrm{S} / \mathrm{cm}$ ) e concentrações de cloreto ( 38 $\mathrm{mg} / \mathrm{L})$, sulfato ( $38 \mathrm{mg} / \mathrm{L})$ e sódio ( $106 \mathrm{mg} / \mathrm{L})$. Existe excesso de sílica dissolvida ( $33 \mathrm{mg} / \mathrm{L})$ em relação ao bicarbonato ( 140 mg/L), no entanto o índice de saturação de calcita neste local é positivo. Os teores de cálcio e magnésio são baixos, em geral menores que $2 \mathrm{mg} / \mathrm{L}$.

O domínio nordeste do aqüífero em São Paulo, representado pelos poços de Guaíra, Barretos, Olímpia e São José do Rio Preto, foi definido por Portugal (2006) como Área V. Esta região apresenta situação de confinamento um pouco mais profundo que na Área II, com características físico-química distintas no que se refere à temperatura $\left(34^{\circ}\right.$ a $48^{\circ} \mathrm{C}$ ), condutividade elétrica (340 e $408 \mu \mathrm{S} / \mathrm{cm}$ ) e valores de $\mathrm{pH}$ (máximo de 9). São águas com concentrações baixas de cloreto (entre 0 e $12 \mathrm{mg} / \mathrm{L}$ ) e sulfato ( 6 a $8 \mathrm{mg} / \mathrm{L}$ ) e relativamente altas da soma de sódio e potássio ( 74 a 92 mg/L). O índice de saturação da calcita apresenta valores muito próximos de zero, ou seja, de situação de equilíbrio da água com este mineral. Os teores de cálcio e magnésio são baixos, em geral menores que 2 mg/L.

Uma área intermediária do SAG foi identificada por Portugal (2006), situada no centro do estado, paralela à calha do rio Tietê. É constituída pelos poços Lins, Araçatuba e Andradina, cujas águas não se enquadram exatamente nas características físico-químicas das outras áreas do SAG. Uma das características marcantes da área intermediária é um decréscimo na temperatura, em comparação com os outros poços a norte e a sul dessa região. A água do poço de Andradina possui características próximas às da Área III; a água do poço de Lins assemelhase bastante com a Área II e Araçatuba possui água com poucas características em comum com as outras áreas. 


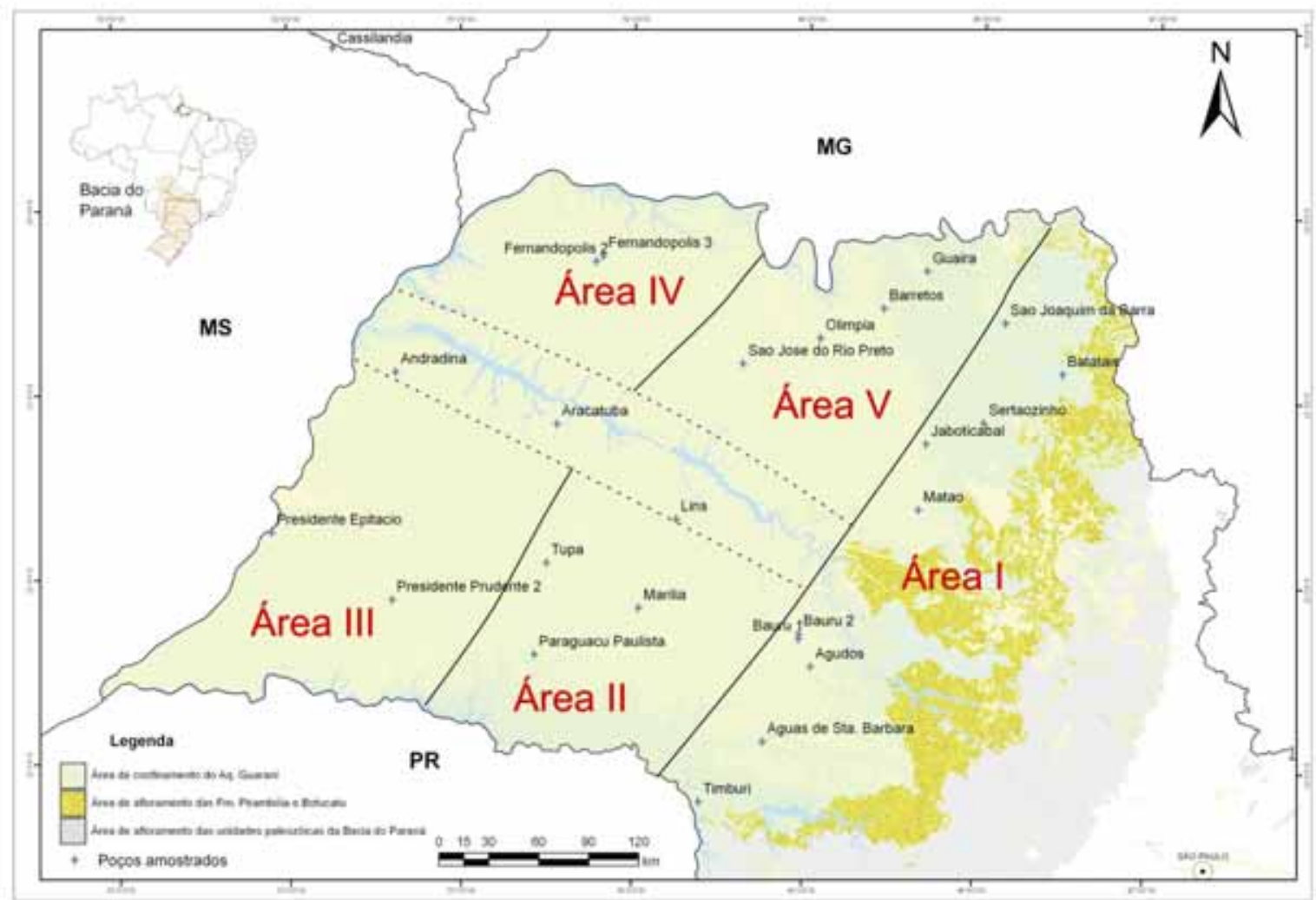

Figura 8.8 - Mapa com a distribuição das áreas hidrogeoquímicas do SAG, segundo modelo conceitual proposto por Portugal (2006).

O limite entre a Área I, a leste, e as áreas II e V, na porção central do aqüífero, corresponde à provável fronteira de troca catiônica do cálcio dissolvido na água pelo sódio adsorvido na rocha. As áreas III e IV, no oeste do estado, possivelmente correspondem ao domínio do SAG que recebe contribuição de águas a partir das rochas do Grupo Passa Dois, subjacente. 


\section{CONSIDERAÇÕES SOBRE A DIAGÊNESE E A EVOLUÇÃO QUÍMICA DO SAG}

O quadro evolutivo diagenético delineado neste trabalho revela que existem diferenças marcantes nas modificações físico-químicas pós-deposicionais entre as rochas das formações Pirambóia e Botucatu, as quais estão relacionadas basicamente com as diferentes características faciológicas dos dois sistemas deposicionais eólicos envolvidos.

A herança das características faciológicas de cada sistema deposicional eólico reside na marcante presença de água no sistema eólico úmido Pirambóia, responsável pela preservação de interdunas e horizontes ricos em finos, em contraposição ao sistema eólico seco Botucatu, relativamente mais homogêneo em termos faciológicos (textura, composição mineralógica e estruturas sedimentares) que o sistema antecessor. Embora o conjunto sedimentar, como um todo, tenha sido submetido a condições de soterramento pouco profundo, no máximo 2000 m na área de estudo, o histórico de soterramento um pouco mais eficiente das rochas da Formação Pirambóia, aliado a características deposicionais desta unidade, com maior variabilidade da composição mineralógica devido ao conteúdo mais elevado de argilominerais, feldspato e minerais acessórios metamórficos, imprimiu-lhe evolução diagnética mais complexa do que a verificada nas rochas da Formação Botucatu.

No entanto, algumas semelhanças diagenéticas podem ser apontadas. Devido a características sedimentológicas que podem ser consideradas típicas de depósitos eólicos em geral, como presença de arenitos isentos de matriz, boa seleção granulométrica e porosidades primárias altas (até $40 \%$ a $45 \%$ ), os depósitos eólicos dunares tanto da Formação Pirambóia quanto da Formação Botucatu apresentam atualmente excelente qualidade de reservatório de água, pois as transformações diagenéticas não foram eficientes a ponto de modificar profundamente as características permo-porosas originais. A presença de cutículas argilosas envoltórias aos grãos do arcabouço, aderidas precocemente, reduziu a formação posterior de sobrecrescimentos minerais e também contribuiu desse modo para a manutenção da porosidade ao longo da evolução diagenética destas unidades.

As características hidrogeoquímicas e as idades aparentes do Sistema Aqüífero Guarani no Estado de São Paulo apontam que a evolução química das 
águas subterrâneas representa a história mais tardia, do ponto de vista diagenético, da interação da água com a rocha. Isto significa que as principais reações químicas no sistema aquífero e a evolução da composição química e isotópica ao longo do rumo de fluxo do aqüífero referem-se à água de origem meteórica de até 30 mil anos atrás, que se infiltrou na zona de afloramentos das unidades (zona de recarga do aqüífero) e vem percolando a rocha já modificada por eventos diagenéticos pretéritos.

A seqüência de modificações diagenéticas sobre os sedimentos das formações Pirambóia e Botucatu, reconhecida neste estudo, revela sucessão de eventos eodiagenéticos, mesodiagenéticos e telodiagenéticos. Será apresentado, adiante, o quadro diagenético evolutivo das unidades (figura 9.1), com reconstituição tentativa da duração relativa e das principais reações químicas envolvidas em cada etapa diagenética.

\subsection{Eodiagênese}

A fase eodiagenética compreende as modificações ocorridas logo abaixo da superfície deposicional, com forte controle das condições climáticas e geoquímicas do ambiente sedimentar. Existe significativo descompasso de tempo entre as modificações precoces verificadas nas rochas das formações Pirambóia e Botucatu, pois durante a deposição desta última unidade, a primeira já se encontrava soterrada havia milhões de anos, e portanto, em estágio mais avançado de diagênese.

\section{Formação Pirambóia (Triássico até limite J uro-Cretáceo)}

Na eodiagênese, as principais modificações verificadas nas rochas da Formação Pirambóia são a adesão de cutículas argilosas de composição esmectítica à superfície dos grãos do arcabouço e a infiltração mecânica de argilas devido à ocorrência de enxurradas esporádicas nos domínios interdunas. É possível que a precipitação de cimentos intersticiais, em condições superficiais, como evaporitos e calcita/dolomita, também tenham ocorrido, porém sem preservação no registro sedimentar. Sob condições de soterramento raso, teria havido favorabilidade para precipitação de cimentos de feldspato potássico e quartzo, este último preferencialmente nos depósitos arenosos de canais e barras de rios entrelaçados. 
Já sob soterramento mais efetivo, surgiriam condições favoráveis à regeneração das cutículas aderidas e eventualmente infiltradas (franjas de esmectitas de hábito crenulado). Inferem-se águas eodiagenéticas salinas ou salobras, com baixas temperaturas.

\section{Formação Botucatu (limite J uro-Cretáceo a Cretáceo I nferior)}

Como a deposição das areias da Formação Botucatu se deu sob condições de nível freático profundo, algumas modificações eodiagenéticas ocorreram na zona vadosa, como infiltração mecânica de argilas e, eventualmente, precipitação localizada de evaporitos. Em condições freáticas, teria ocorrido a adesão de cutículas argilosas à superfície dos grãos do arcabouço. À semelhança da Formação Pirambóia, as águas eodiagenéticas seriam salinas ou salobras, com baixas temperaturas.

\subsection{Mesodiagênese}

A mesodiagênese está associada ao soterramento efetivo dos depósitos das formações Pirambóia e Botucatu devido ao início da atividade vulcânica na Bacia do Paraná e solidificação de grande volume de rochas da Formação Serra Geral (Cretáceo Inferior), seguido pela deposição dos sedimentos da Bacia Bauru (Cretáceo Superior). O evento magmático é também apontado como principal desencadeador da geração e migração de hidrocarbonetos na bacia, responsável pelo desenvolvimento do sistema petrolífero Irati-Pirambóia (Araújo 2003). A datação das rochas efusivas e intrusivas da Formação Serra Geral no Cretáceo Inferior (137-127 Ma, segundo Turner et al. 1994) e a ocorrência de arenitos asfálticos, cuja exumação data provavelmente do esculpimento da Depressão Periférica, no Terciário, permitem deduzir que as principais modificações mesodiagenéticas ocorreram ao longo do período Cretáceo.

O soterramento efetivo das formações Pirambóia e Botucatu imprimiu condições de sistema fechado na diagênese avançada. Assim, é razoável inferir que as condições geoquímicas das águas intersticiais neste período seriam as herdadas das condições climáticas e deposicionais vigentes na eodiagênese, ou seja, de águas salinas ou salobras, posteriormente submetidas a temperaturas mais altas, 
provavelmente da ordem de 50 a $100^{\circ}$ C, devido ao presumível aumento do gradiente geotérmico na bacia propiciado pelo magmatismo Serra Geral.

\section{Formação Pirambóia (Cretáceo Inferior a Superior)}

Processos que podem ser atribuídos à fase mesodiagenética na Formação Pirambóia compreendem: a compactação física e química nas porções mais profundas da bacia, com amassamento de fragmentos líticos, fraturamento de grãos de feldspato e geração de contatos interpenetrativos entre grãos; provável illitização parcial da esmectita regenerada, cuja reação libera sílica e cátions; e geração de cimentos sintaxiais de quartzo e feldspato, favorecidos pela dissolução por pressão e pela liberação de sílica do processo de illitização. Localmente, teria ocorrido a entrada de hidrocarbonetos nos arenitos da porção inferior da unidade. Em estágio mais avançado, presume-se o início do evento de cimentação de calcita intersticial. Inferem-se condições geoquímicas de sistema fechado, águas intersticiais salinas, temperaturas altas e reações químicas regidas primordialmente por difusão iônica.

\section{Formação Botucatu (Cretáceo I nferior a Superior)}

Na Formação Botucatu, a mesodiagênese é caracterizada por: compactação física e química nas porções mais profundas da bacia, com fraturamento de grãos de feldspato e mica e geração de contatos entre grãos interpenetrativos; regeneração incipiente das cutículas aderidas precocemente, de composição esmectítica; e geração de cimentos sintaxiais de quartzo e feldspato nas porções mais profundas da bacia, favorecida pela dissolução por pressão. Inferem-se as mesmas condições de sistema fechado da Formação Pirambóia.

\subsection{Telodiagênese}

Com o soerguimento da borda leste da Bacia do Paraná, iniciado já no final do Cretáceo (110-90 Ma, segundo Araújo et al. 1999), foi criado gradiente hidráulico na bacia e início de influxo de águas meteóricas nas formações Pirambóia e Botucatu, a partir das zonas aflorantes a leste, em São Paulo. No final do Cretáceo, no entanto, predominava clima árido, reinante durante toda a deposição dos sedimentos da Bacia Bauru. A partir do Terciário Médio (15 Ma), com o 
rejuvenescimento do relevo a leste e instalação de clima predominantemente úmido, teria se iniciado o processo de invasão profunda de águas doces nestas unidades (Araújo et al. 1999) e a configuração do Sistema Aqüífero Guarani. Devido às características sedimentológicas das formações Pirambóia e Botucatu e ao histórico de pequeno soterramento, foi possível a percolação profunda de águas diluídas provenientes da área de recarga e início da fase de extensiva lixiviação mineral (França et al. 2003), com ampliação da porosidade original das rochas. A instalação do regime telodiagenético é responsável pela principal fase de geração de porosidade secundária nas rochas das formações Pirambóia e Botucatu.

\section{Formação Pirambóia (Terciário Médio ao Recente)}

O principal processo telogenético da Formação Pirambóia é a geração de porosidade secundária por lixiviação de cimentos prévios (calcita e eventuais evaporitos) e grãos instáveis do arcabouço, principalmente feldspato, minerais acessórios e micas. Nos domínios marginais, próximos à zona de afloramento, verifica-se principalmente redistribuição da porosidade secundária, com a dissolução de minerais instáveis associada à precipitação de caulinita. No domínio de confinamento intermediário (até 500 m), a troca catiônica entre água e rocha resgata o cálcio dissolvido pela precipitação de calcita e, possivelmente, pela adsorção nos argilominerais dos horizontes pelíticos (domínios de interdunas). Sob condições de confinamento profundo $(>1000 \mathrm{~m}$ ), a redistribuição da porosidade secundária está associada à substituição mineral parcial de feldspato por argilominerais ("sericitização"). Aventa-se, também, a possibilidade de illitização de esmectita sob condições de maior confinamento. Nas porções mais profundas da bacia, a possível ascensão de águas mais salinizadas, provenientes das unidades subjacentes (Grupo Passa Dois), aportaria ao aqüífero íons dissolvidos, principalmente $\mathrm{Na}, \mathrm{SO}_{4}, \mathrm{Cl}$ e $\mathrm{F}$. As características físico-químicas do aqüífero resultam de águas pouco mineralizadas, com $\mathrm{pH}$, condutividade elétrica e temperatura crescentes da borda para o interior da bacia, no sentido do fluxo subterrâneo, de E para W-SW. 


\section{Formação Botucatu (Terciário Médio ao Recente)}

Também na Formação Botucatu, a telogênese é marcada pela geração de porosidade secundária através da lixiviação de cimentos prévios (eventuais evaporitos e carbonatos) e de grãos do arcabouço quimicamente instáveis. É possível que as condições favoráveis à precipitação de caulinita sejam restritas à zona de afloramento da unidade. Nos domínios de pequeno confinamento, próximos à faixa de afloramento, as características geoquímicas das águas favorecem a precipitação de sílica de baixa cristalinidade e criptocristalina (opala e calcedônia). Sob condições de confinamento profundo (>1000 m), verifica-se redistribuição da porosidade secundária, à semelhança da Formação Pirambóia, com substituição parcial de feldspato por argilominerais ("sericitização"). As características físicoquímicas do aqüífero são de águas pouco mineralizadas, com variação de parâmetros geoquímicos da borda (zona de recarga a leste) para o interior (W-SW).

\begin{tabular}{|c|c|c|c|c|c|c|c|}
\hline \multicolumn{2}{|c|}{ EODIAGÊNESE } & \multicolumn{2}{|c|}{\begin{tabular}{|c|c} 
& MESODIAGÊNESE \\
1 & BOT
\end{tabular}} & 1 & \multicolumn{3}{|c|}{ TELODIAGÊNESE } \\
\hline & $\begin{array}{l}\quad \text { BOT } \\
\text { - Precipitaçắo de } \\
\text { evaporitos (?) } \\
\text { - Argllas infiltradas } \\
\text { mecanicamente }\end{array}$ & 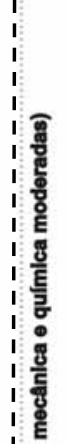 & $\begin{array}{l}\text { - Cimento de quartzo e } \\
\text { felspato } \\
\text { - Regeneraçăa de cutticulas } \\
\text { argiliosas (incipiente } \\
\text { neoformaçăo de esmectita) }\end{array}$ & 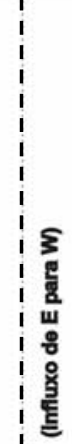 & $\begin{array}{l}\text { - Geraçắ de } \\
\text { porosidade } \\
\text { secundária } \\
\text { (dissoluçăo de } \rightarrow \\
\text { cimentos } \theta \\
\text { arcabouç } \\
\text { instável) }\end{array}$ & 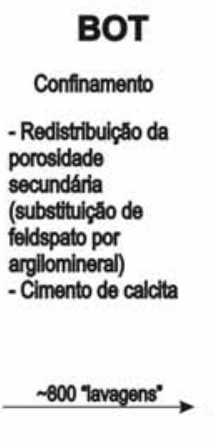 & $\begin{array}{l}\quad \text { Borda } \\
\text { - Dissoluçắo } \\
\text { mineral } \\
\text { - Neoformaçắo de } \\
\text { caolinita } \\
\text { - Cimento de opala } \\
\text { e calcedônia } \\
T=25^{\circ}-70^{\circ} \mathrm{C} \\
\text { Aquifero doce }\end{array}$ \\
\hline 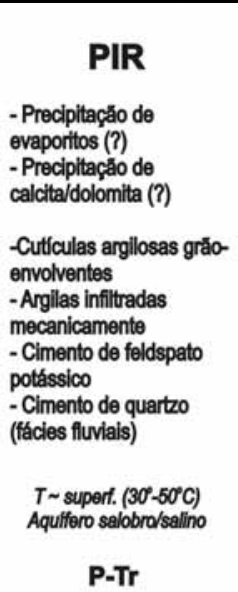 & $\begin{array}{l}\text {-Regeneraç̆o de cutticulas } \\
\text { arglilosas } \\
\text { (neoformaçăo de esmectita) } \\
\text {-Cimento de quartzo e } \\
\text { felspato (inciplente) }\end{array}$ & 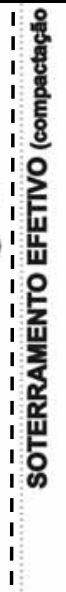 & $\begin{array}{l}\text {-Cimento de quartzo e } \\
\text { felspato } \\
\text { - Illitizaçăo da esmectita } \\
\text { - Cimento de calcita } \\
\text {-Cimento de betume }\end{array}$ & 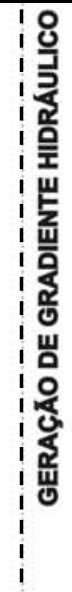 & $\begin{array}{l}\text { - Geraçăa de } \\
\text { porosidade } \\
\text { secundária } \\
\text { (dissoluçăo de } \\
\text { cimentos } \theta \\
\text { arcabougso } \\
\text { instavel) } \\
\text {-Degradaçăa } \\
\text { do petroleo }\end{array}$ & 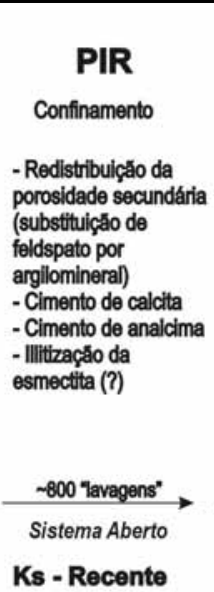 & \begin{tabular}{l}
\multicolumn{1}{c}{ Borda } \\
- Dissoluçăa \\
mineral \\
- Neoformaçăo de \\
caolinita
\end{tabular} \\
\hline
\end{tabular}

Figura 9.1 - Quadro diagenético evolutivo das formações Pirambóia (PIR) e Botucatu (BOT) no Estado de São Paulo. P-Tr -Permiano ao Triássico; J/K - Ki - limite Juro-Cretáceo ao Cretáceo Inferior; Ki - Ks - Cretáceo Inferior ao Cretáceo Superior; Ks - recente - Cretáceo Superior ao recente. 


\subsection{Evolução do SAG em São Paulo}

As águas meteóricas que infiltram no rumo geral oeste, a partir da zona de recarga do Aqüífero Guarani (zona aflorante das formações Pirambóia e Botucatu), são inicialmente ácidas e oxidantes. A acidez é rapidamente neutralizada pela dissolução de pequenas quantidades de carbonato ou de minerais aluminossilicáticos, como feldspato e micas. Ao longo do fluxo subterrâneo, as águas adquirem maior pH (por incorporação de cátions alcalinos e alcalinos terrosos) e tornam-se progressivamente mais redutoras. Com o aumento da profundidade, aumenta também a temperatura, e dependendo da paragênese mineral, as águas podem alcançar a saturação com respeito a minerais silicáticos (quartzo) e carbonáticos (calcita). A solubilidade dos minerais alumino-silicáticos é, no geral, baixa nas condições físico-químicas diagenéticas; portanto, a neoformação de minerais a partir da relação água-rocha é fortemente dependente da dissolução simultânea de outros minerais ou fases instáveis quimicamente (Bjørlykke \& Aagaard 192). As reações químicas ligadas à ação das águas superficiais que percolam a rocha consolidada (estágio telodiagenético) geralmente são restritas a poucas centenas de metros de profundidade, fluxo subterrâneo adentro. No entanto, a percolação de águas meteóricas nas formações Pirambóia e Botucau tem sido apontada como exemplo de profunda invasão num sistema aqüífero supostamente aberto e de alta permeabilidade (França et al. 2003).

A porção marginal do SAG, que engloba a faixa de afloramentos das formações Pirambóia e Botucatu e porções de pequeno confinamento do SAG (correspondente à Área I de Portugal 2006), apresenta águas com composição bicarbonatada cálcica e magnesiana. As características hidrogeoquímicas apontam a ação de águas diluídas, ácidas a neutras, as quais se encontram em equilíbrio com caulinita (poços Cassilândia, Timburi e Batatais), muscovita (São Joaquim da Barra) e esmectita (Matão, Sertãozinho e Jaboticabal). Esta zona apresenta índices de saturação positivo para calcedônia e negativo para calcita, o que significa tendência de precipitação da primeira e dissolução da segunda.

Estes índices teóricos são compatíveis com as observações petrográficas das rochas do aqüífero, já que foi constatada presença de cimento de caulinita em amostras de afloramento e de calha da Formação Pirambóia nos poços de Sta. Rosa do Viterbo, Santa Lúcia, São Carlos e Orlândia. Nos poços da Área 1, a presença marcante de porosidade secundária intraconstituinte (alveolar e móldica) revela a ação agressiva da água e demarca zona de intensa lixiviação mineral, 
principalmente de felspato. A dissolução mineral provavelmente está associada à precipitação de caulinita intersticial (Formação Pirambóia) ou à substituição pseudomórfica de felspato e precipitação de sílica (Formação Botucatu). O cimento de calcita está ausente na porção aflorante das unidades, no entanto foi encontrado na Formação Pirambóia mesmo em poços próximos à borda de confinamento do aqüífero, como em Sertãozinho, Batatais e Matão.

A fronteira de efetiva dissolução mineral nas formações Pirambóia e Botucatu, responsável pela geração de volume significativo de poros secundários nas zonas marginais, pode ser balizada entre os poços de Barretos e São Joaquim da Barra, no norte do estado, e entre Bauru e Marília, no sul. A fronteira de precipitação de caulinita na Formação Pirambóia e de sílica (opala, calcedônia e quartzo) na Formação Botucatu é mais recuada, restrita à proximidade com a zona de afloramento destas unidades (figura 9.2).

Podem-se destacar duas situações de anomalia na Área 1, representadas pelos poços de Bauru, no centro-sul do estado, e Matão, no centro-norte. Nestes poços, foram encontradas as duas únicas ocorrências de cimento tardio de calcita (telodiagenético) em arenitos da Formação Botucatu. Na região de Bauru, existe uma "janela" subterrânea do Aqüífero Guarani, onde as formações Pirambóia e Botucatu situam-se em profundidades rasas (50 a $250 \mathrm{~m}$ ) e são sobrepostas diretamente pelas rochas da Bacia Bauru devido à erosão pontual dos vulcanitos da Formação Serra Geral. Nos poços de Matão, o topo do aqüífero está soterrado em profundidades relativamente altas (300 a 400 m), apesar da proximidade à zona aflorante, e suas águas subterrâneas apresentam os mais elevados conteúdos de cálcio e magnésio do SAG.

As características químicas das águas subterrâneas da região de Bauru mostram equilíbrio tanto com a calcita quanto com a calcedônia, tendo em vista os valores positivos, próximos de zero, dos índices de saturação destes minerais. Os dados petrográficos corroboram o modelo teórico, uma vez reconhecidas feições de substituição de cimento de sílica por calcita microespática em amostras de arenito da Formação Botucatu no poço de Bauru (código B18).

Nos poços de Matão, existe contraposição entre a composição química das águas e as feições diagenéticas observadas. As águas apresentam índice de saturação negativo com relação à calcedônia e à calcita, situação que demonstra tendência de dissolução ao invés de precipitação destes minerais. No entanto, verifica-se extensiva cimentação telodiagenética de calcita tanto nos arenitos 
Pirambóia (porção superior) quanto Botucatu. É possível que as concentrações altas de cálcio e magnésio, nesta região, tenham induzido a precipitação de carbonato no conjunto sedimentar. A grande oferta destes cátions na água não pode ser explicada por fonte interna de íons (dissolução de minerais instáveis), o que leva à hipótese de uma eventual contribuição de águas provenientes da Formação Serra Geral ou do Grupo Passa Dois e do controle estrutural de fluxo de água para o SAG, através de zonas de cisalhamento.

O mapa potenciométrico do Aqüífero Guarani e os dados isotópicos e químicos das águas obtidos em Portugal (2006) indicam que existe fluxo subterrâneo e evolução das águas da Área 1 para a Área 2 (sul do estado) e da Área 1 para a Área 5 (norte do estado). No entanto, observam-se diferenças marcantes nas características geoquímicas das águas confinadas do SAG do domínio norte e sul do estado, com limite balizado pela calha do rio Tietê.

A Área 5 do SAG, setentrional, apresenta águas de composição bicarbonatada sódica, pH alcalino $(9,1$ a 9,5), com concentrações baixas de cálcio, cloreto e sulfato dissolvidos. Neste domínio, as rochas das formações Pirambóia e Botucatu situam-se em profundidades de 500 a 1000 m e os minerais diagenéticos, como a esmectita das cutículas regeneradas e a calcita intersticial tardia (Formação Pirambóia), encontram-se em equilíbrio com as águas subterrâneas.

Na Área 2 do SAG, meridional, a situação de confinamento das rochas das formações Pirambóia e Botucatu é da ordem de 600 a $1200 \mathrm{~m}$ de profundidade. As águas subterrâneas são de composição bicarbonatada sódica, pH alcalino (9,6 a $10,0)$ e pequeno conteúdo de cálcio, cloreto e sulfato dissolvidos. O índice de saturação da calcita na água é negativo e existe excesso de sílica dissolvida. Infelizmente, não há dados petrográficos de poços deste domínio para checar se existe de fato predomínio de dissolução mineral de carbonato e aluminossicatos nas rochas do aqüífero.

A mudança das características hidroquímicas do SAG entre o domínio marginal do aqüífero (Área 1) e de confinamento (Áreas 2 e 5), respectivamente, de águas bicarbonatadas cálcicas para sódicas, provavelmente está relacionada ao fenômeno de troca catiônica entre água e rocha (Sracek \& Hirata 2002), uma vez que o decréscimo dos íons cálcio é acompanhado pelo acréscimo, na mesma proporção, de íons sódio. A troca catiônica ocorre preferencialmente nos espaços trocáveis dos argilominerais (adsorção à superfície ou nos espaços interfoliares), sendo que a esmectita tem maior capacidade de troca catiônica que caulinita, illita 
e clorita. Os argilominerais reconhecidos nos arenitos das formações Pirambóia e Botucatu ocorrem principalmente na forma de cutículas envoltórias, as quais foram regeneradas ao longo da diagênese, com neoformação de esmectita e de camadas mistas esmectita/illita. Devido ao maior conteúdo de argilominerais na Formação Pirambóia, em vista das características faciológicas desta unidade, como argilas infiltradas e estratos argilosos típicos dos domínios interdunares, é razoável inferir que a fronteira de troca catiônica do cálcio pelo sódio no SAG seja regida preferencialmente pela Formação Pirambóia.

As zonas de grande confinamento do SAG situam-se no extremo ocidental do estado, onde as formações Pirambóia e Botucatu encontram-se em profundidades abaixo de $1000 \mathrm{~m}$. Neste contexto, foram definidas duas zonas hidrogeoquímicas do aqüífero por Portugal (2006), a Área 3 e a Área 4. As águas destes domínios são também bicarbonatadas sódicas, porém com concentrações altas de cloreto e sulfato, as quais crescem no sentido sudoeste do estado.

A direção de fluxo subterrâneo do SAG verificada na Área 4 (porção norte) difere do padrão geral de fluxo no estado, pois apresenta sentido de NNE para SSW. Esta configuração demonstra que as águas nesta área são provenientes do Triângulo Mineiro e não há dados disponíveis na literatura sobre as características químicas, comportamento hidráulico e condições de recarga do aqüífero nesta região. Pode-se afirmar, contudo, que as águas da Área 4 não evoluem a partir da Área 5, a leste. A principal característica hidroquímica da Área 4 é o excesso de sílica dissolvida, apesar do aparente equilíbrio da águas com relação à calcita e à esmectita. Este excesso de sílica pode ser explicado pela dissolução preferencial de feldspatos verificada nos arenitos da Formação Pirambóia no poço de Fernandópolis, onde o conteúdo de porosidade secundária intragranular é de até $2,2 \%$ da rocha.

A Área 3, no extremo sudoeste do estado, apresenta as maiores profundidades de confinamento (até quase $2000 \mathrm{~m}$ ) e as maiores concentrações de íons cloreto, sulfato, bicarbonato, sódio e fluoreto do SAG em São Paulo. As águas encontram-se em equilíbrio com esmectita e calcita, embora o excesso de carbonato dissolvido favoreça a precipitação deste último mineral nos poços de Andradina e Presidente Prudente. A Formação Botucatu é essencialmente porosa, mesmo sob condições de grande confinamento e de águas saturadas em carbonato. Assim como no restante da bacia, o horizonte prefencial de cimentação de calcita situa-se no domínio superior da Formação Pirambóia, como se observa nos poços 
de Presidente Epitácio, Presidente Prudente e Araçatuba. O excesso de sódio nas águas do poço de Presidente Prudente provavelmente reflete as características hidroquímicas da base da Formação Pirambóia, próximo à transição com o Grupo Passa Dois, em cujo horizonte foi reconhecido cimento de analcima.

A evolução das águas do SAG de bicarbonatadas cálcio-magnesianas, na zona marginal da bacia, para bicarbonatadas sódicas e cloro-sulfatadas sódicas em direção ao centro da bacia já havia sido delineada por Silva (1983). Esta autora apontou que o tempo de residência longo da água em contato com a rocha e a dissolucão mineral no substrato do aqüífero ao longo do fluxo subterrâneo seriam suficientes para explicar as variações na composição química das águas do SAG em SP. Meng \& Maynard (2001) e Sracek \& Hirata (2002) aventaram, ainda, a possibilidade de contribuição de águas ricas em sulfato, cloreto e sódio a partir das unidades subjacentes do aqüífero. Estes últimos autores demostraram, através de cálculos de balanço de massa, que o aumento da concentração de sódio na água não pode ser atribuído exclusivamente a uma fonte interna de íons (dissolução de aluminossilicatos) e que uma fonte alternativa poderia ser a difusão de íons derivados da dissolução de sais e evaporitos do Grupo Passa Dois.

De fato, não foram encontrados vestígios diretos da presença de minerais evaporíticos nos arenitos das formações Pirambóia e Botucatu, embora as características faciológicas dos sistemas deposicionais eólicos de cada unidade sejam muito sugestivas de que estes minerais possam ter precipitado precocemente nas rochas, durante estágio eodiagenético. O histórico de invasão profunda de águas meteóricas no SAG pode ter eliminado por completo estes cimentos mais solúveis. Considerando os parâmetros hidráulicos apresentados por Silva (1983) e Sracek \& Hirata (2002), de que a condutividade do SAG em São Paulo é, em média, $27 \mathrm{~m} / a n o$, e considerando que a configuração atual do aqüífero se estabeleceu provavelmente no Terciário Superior (Araújo et al. 1999), as rochas das formações Pirambóia e Botucatu em São Paulo sofreram teoricamente por volta de 800 lavagens nos últimos 15 Ma.

A contribuição de íons sódio, sulfato, cloreto e fluoreto a partir das unidades subjacentes do SAG é uma hipótese favorecida por vários aspectos: a) a abundância de minerais-fonte destes íons (carbonatos e evaporitos) no Grupo Passa Dois; b) as condições de grande confinamento das rochas próximo à calha da bacia, o que pode impor fluxo compactacional ascendente das unidades permianas para o aqüífero, mais permeável; c) o possível favorecimento do fluxo 
compactacional ascendente por estruturas rúpteis como fraturas e falhas; d) o enriquecimento preferencial nesses íons do domínio basal do SAG, representado pelas rochas da Formação Pirambóia, situado mais próximo das rochas do Grupo Passa Dois.

A provável fronteira de contribuição de íons no SAG a partir das unidades permianas pode ser delineada entre os poços de Paraguaçu Paulista e Presidente Prudente, no sul do estado, entre Lins e Araçatuba no centro do estado e entre Rio Preto e Fernandópolis, no norte (figura 9.2).

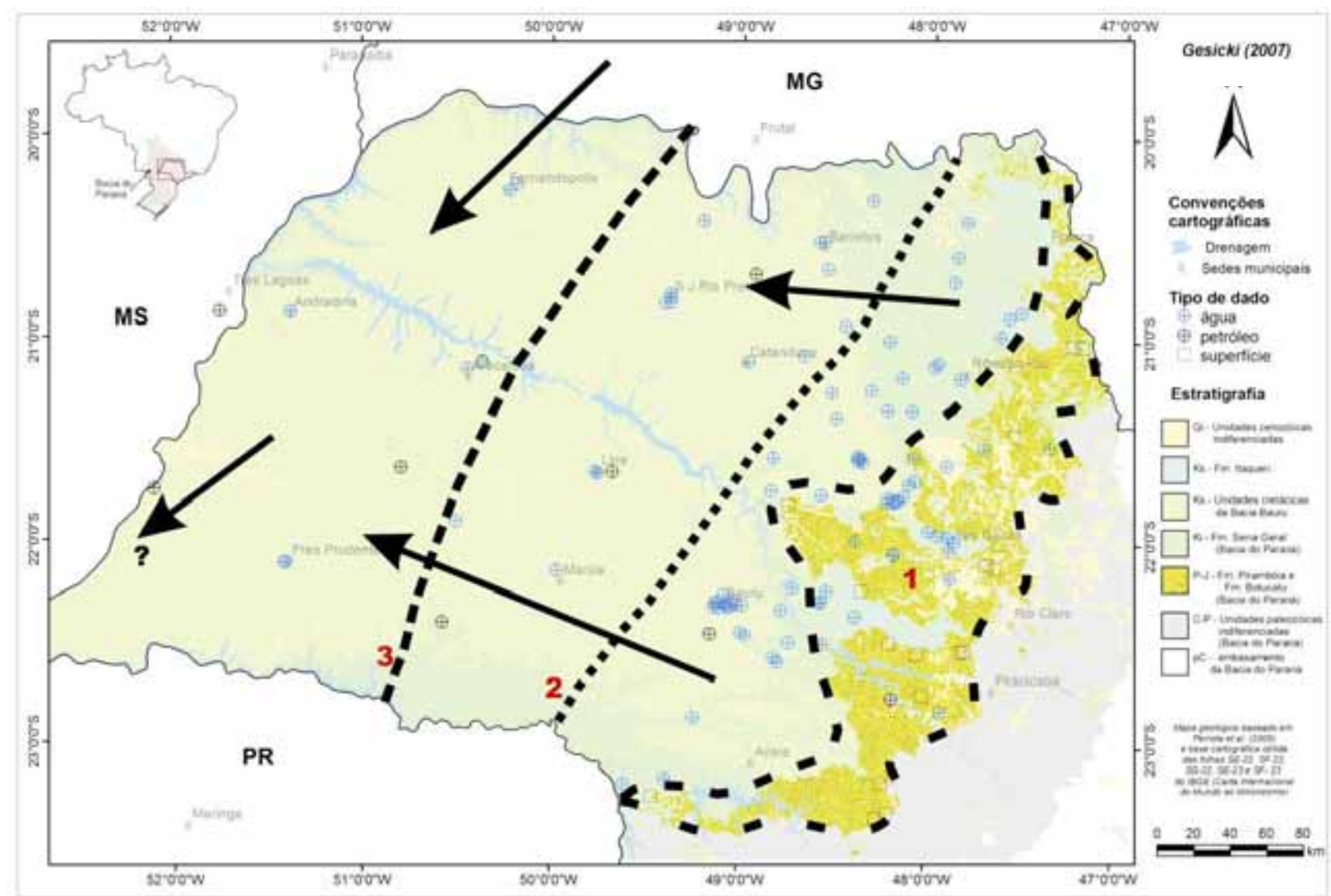

Figura 9.2 - Evolução hidráulica do SAG e principais fronteiras de modificação química das águas. 1: área de precipitação da caulinita; 2: fronteira de troca catiônica do cálcio da água pelo sódio da rocha; 3: limite de ascensão das águas provenientes do Grupo Passa Dois. Setas: direção média de fluxo subterrâneo. 


\section{CONCLUSÕES}

1) A deposição dos sedimentos das formações Pirambóia e Botucatu no Estado de São Paulo está associada ao desenvolvimento, respectivamente, de sistema eólico úmido e sistema eólico seco, sensu Kocurek \& Havholm (1993). A duração do hiato temporal envolvido na discordância entre os depósitos destes dois sistemas ainda não pôde ser estabelecida com precisão.

2) O sistema eólico úmido Pirambóia é caracterizado por associações de fácies eólicas (dunas, interdunas e raros lençóis de areia) seguida de associação subaquosa de canais e barras de rios entrelaçados. Os depósitos eólicos da porção inferior teriam sido desenvolvidos em contexto costeiro marginal ao sistema marinho Passa Dois, com intensa, porém descrescente influência de inundações nas interdunas, da base para o topo da unidade.

3) O sistema eólico seco Botucatu reflete deposição sob condições de extrema aridez e influência mínima de água. O desfecho deste sistema é atribuído às manifestações vulcânicas na Bacia do Paraná (Formação Serra Geral).

4) O modelo genético definido em superfície para o sistema eólico úmido Pirambóia e o sistema eólico seco Botucatu foi testado em subsuperfície através da revisão de material de calha e perfis de poços de captação de água no Estado de São Paulo. O limite estratigráfico entre os depósitos dos dois sistemas pôde ser identificado na maior parte dos poços estudados, com base no contato entre os horizontes areno-rudáceos de contexto flúvio-eólico, do topo do sistema Pirambóia, e os arenitos eólicos da base do sistema Botucatu.

5) A presença marcante de depósitos areno-rudáceos na porção superior da Formação Pirambóia norteou o agrupamento das lâminas petrográficas de amostras de calha em dois grupos genéticos maiores: o das fácies eólicas, referentes aos depósitos dunares e interdunares, e o das fácies flúvio-eólicas.

6) A Formação Pirambóia é contituída por arenitos finos a grossos, bimodais, com seleção ruim a boa, de composição predominantemente feldspática ( $F>10 \%)$ e arcabouço tipicamente frouxo, mesmo em grandes profundidades. É comum a ocorrência de argila diagenética infiltrada mecanicamente. Os principais componentes diagenéticos são cutículas argilo-ferruginosas grão-envolventes, esmectita neoformada e cimentos de feldspato, quartzo, calcita e, localmente, betume. 
7) A Formação Botucatu é caracterizada pelo predomínio de quartzo-arenitos de granulometria fina a média, seleção moderada a boa e arcabouço aberto. Os principais componentes diagenéticos são cutículas argilo-ferruginosas grãoenvolventes, esmectita neoformada incipiente, cimentos de quartzo e feldspato e, localmente, cimento de opala, calcedônia e calcita.

8) Duas petrofácies foram estabelecidas, a dos quartzo-arenitos (QA) e a dos arenitos feldspáticos (FA), ambas subdivididas nos tipos 1 e 2 com base, respectivamente, na presença ou ausência de cutículas argilosas precoces. Subtipos puderam ser também identificados, levando em conta o componente diagenético principal: p- poros, c - cimento de calcita, f - cimento de feldspato, i - argilas infiltradas mecanicamente, s - cimento de sílica, b - cimento de betume.

9) Os depósitos eólicos da Formação Pirambóia compreendem as petrofácies FA1p, FA1c, FAb, FAi, QA1p e QA1c, enquanto os depósitos flúvio-eólicos da mesma unidade são constituídos principalmente pela petrofácies QA2c e QA2p, além de QA2f. A ocorrência de petrofácies com cimento carbonático intersticial apresenta ampla distribuição na bacia, exceto na zona aflorante da unidade, e está posicionada na porção superior da Formação Pirambóia, abaixo do contato discordante com a Formação Botucatu.

10) A Formação Botucatu é caracterizada por menor variedade de petrofácies, com predomínio de QA1p e presença secundária de FA1p, QA1c e QA1s. A distribuição das petrofácies com cimento intersticial (calcita e sílica) é restrita à zona de afloramentos ou de pequeno confinamento da unidade.

11) A evolução diagenética das formações Pirambóia e Botucatu abrangeu eventos ocorridos em estágio eo, meso e telodiagenético. O soterramento pouco profundo, no máximo 2000 m, não foi suficiente para imprimir modificações marcantes nas propriedades permo-porosas originais das unidades. A porosidade média, a partir de imagens de seções delgadas das petrofácies porosas, é de 18,9\% para a Formação Pirambóia e 19,5\% para a Formação Botucatu.

12) A Formação Pirambóia apresenta evolução diagenética mais complexa, se comparada à da Formação Botucatu. Esta complexidade deve-se à herança faciológica, com maior diversidade mineralógica (composição feldspática, maior conteúdo de argilominerais e de minerais acessórios metamórficos), e ao histórico mais longo de soterramento. 
13) O estágio eodiagenético da Formação Pirambóia é caracterizado por adesão de cutículas argilosas-ferruginosas, regeneradas em estágio mais avançado (neoformação de esmectita), e pela cimentação por feldspato e quartzo, principalmente nas petrofácies com ausência de cutículas precoces. O estágio mesodiagenético caracteriza-se por compactação mecânica e química incipientes a moderadas, cimentação por quartzo e feldspato em condições de soterramento efetivo, provável illitização de esmectitas neoformadas e, eventualmente, cimentação por calcita. Neste estágio, teria ocorrido também a entrada de petróleo nos reservatórios do domínio inferior da unidade. O estágio telodiagenético é caracterizado pela principal fase de geração de porosidade secundária, além de neoformação de argilominerais e de cimentação por calcita e analcima.

14) Na Formação Botucatu, o estágio eodiagenético compreendeu a adesão de cutículas argilo-ferruginosas e a infiltração mecânica de argilas em condições vadosas. O estágio mesodiagenético incluiu compactação mecânica e química pouco eficientes e incipiente neoformação de esmectita (regeneração da cutícula precoce), além de cimentação por quartzo e feldspato nas porções de confinamento mais profundas. No estágio telodiagenético, ocorre a ampliação da porosidade original pela infiltração profunda de águas diluídas, a partir das bordas da bacia. Em condições marginais, há ainda cimentação de sílica de baixa cristalinidade e de calcita.

15) As águas subterrâneas na zona de recarga e pequeno confinamento do SAG possuem altas concentrações do cátion cálcio, indicando água bicarbonatada cálcica, com concentrações razoáveis de magnésio. As águas tornam-se mais ricas em cátions sódio e potássio e em ânions cloreto e sulfato, à medida que aumenta, rumo oeste, o confinamento e profundidade do aqüífero, o que torna a composição das águas do tipo bicarbonatada sódica e cloro-sulfatada.

16) As águas na zona marginal do SAG possuem temperaturas baixas ( $\leq$ $30^{\circ} \mathrm{C}$ ), $\mathrm{pH}$ baixo a médio (entre 5,5 e 8,0 ), condutividade elétrica baixa ( $\leq 250$ $\mu \mathrm{S} / \mathrm{cm}$ ), e os valores mais elevados de cálcio e magnésio do aqüífero (até $40 \mathrm{mg} / \mathrm{L}$ e $4,0 \mathrm{mg} / \mathrm{L}$, respectivamente). Cloreto e sulfato estão ausentes na sua composição. A soma de bicarbonato e carbonato apresenta baixos valores ( $<150 \mathrm{mg} / \mathrm{L}$ ), bem como a soma de sódio e potássio ( $<35 \mathrm{mg} / \mathrm{L}$ ).

17) As águas na zona de confinamento do SAG possuem temperaturas altas (médias acima de $40^{\circ} \mathrm{C}$, com valores de até $65^{\circ} \mathrm{C}$ ), $\mathrm{pH}$ elevado $(>8,0$ a até 10,0$)$, 
condutividade elétrica alta (até $1.250 \mu \mathrm{S} / \mathrm{cm}$ ), concentração de magnésio próximo de zero e concentração de cálcio menor que 2,0 mg/L. Observam-se também valores relativamente elevados de cloreto (até $130 \mathrm{mg} / \mathrm{L}$ ) e sulfato (até $99 \mathrm{mg} / \mathrm{L}$ ). A soma de bicarbonato e carbonato apresenta valores de até $370 \mathrm{mg} / \mathrm{L}$ e a de sódio e potássio, até $311 \mathrm{mg} / \mathrm{L}$.

18) O modelamento teórico dos índices de saturação de minerais nas águas subterrâneas indica dissolução de calcita na zona de recarga (afloramento) e em subsuperfície, nas regiões de Barretos, Marília, Paraguaçu Paulista e Tupã, e precipitação do mesmo mineral nas demais regiões de confinamento do aqüífero. Para calcedônia, a precipitação é indicada na zona de recarga e na região sudoeste do estado, de maior confinamento e profundidade do aqüífero; e a dissolução é sugerida na região central (Fernandópolis, Barretos, Tupã, Lins) e em Matão (zona de recarga), onde se encontra a tendência mais alta de dissolução desse mineral.

19) Através dos índices hidroquímicos identificou-se fonte de cálcio tanto na zona de recarga como na de pequeno confinamento do SAG. Rumo ao interior do aqüífero, este cátion esse estaria sendo retirado da água por precipitação e/ou troca iônica. Na zona de recarga e nas regiões de Fernandópolis, Marilia, Tupã e Paraguaçu Paulista, têm-se condições hidrogeoquímicas favoráveis para a precipitação de sílica, enquanto na zona de confinamento profundo, entre as regiões de Presidente Prudente e Andradina, as condições favorecem a precipitação de carbonato. A precipitação dos dois minerais é indicada nas demais áreas do aqüífero.

20) A configuração do SAG foi delineada a partir do final do período Cretáceo, quando o soerquimento da borda leste da bacia criou gradiente hidráulico e deu início à infiltração de águas superficiais (meteóricas) de leste para oeste (Araújo et al. 1999) no estado. A partir do Terciário Médio, em contexto de instalação de clima úmido, a invasão profunda de águas vindas da zona de recarga e a modificação das características hidroquímicas do aqüífero aproximam-no de sua composição atual.

21) A análise diagenética das formações Pirambóia e Botucatu revela que a configuração hidrogeoquímica atual do SAG está associada à interação rocha / água durante o estágio telodiagenético mais tardio daquelas unidades, referente à percolação das águas, nos últimos 30000 anos, através de substrato rochoso previamente modificado por eventos diagenéticos pretéritos. 
22) O quadro hidrogeoquímico do SAG no Estado de São Paulo, delineado por Portugal (2006), revela que na zona de recarga do sistema (Área 1), as águas diluídas e bicarbonatadas cálcicas favorecem a dissolução de cimento carbonático e de arcabouço quimicamente instável e a co-precipitação de fases secundárias (argilominerais e sílica de baixa cristalinidade). As águas da Área 1 evoluem para a Área 2, no sul do estado, e para a Área 5, no norte, onde adquirem composição bicarbonatada sódica, com aumento de temperatura e $\mathrm{pH}$, e delimitam, nesta passagem, a fronteira de troca catiônica do cálcio por sódio. Não há aparentemente evolução das águas da Área 5 para a Área 4, uma vez que as águas deste domínio provêm de norte, a partir do Triângulo Mineiro. No sul do estado, a evolução das águas da Área 2 para Área 3 representa modificação das características hidrogeoquímicas em direção a composição bicarbonatada sódica rica em íons cloreto, sulfato e fluoreto. No domínio sudoeste do estado, o enriquecimento progressivo nestes íons provavelmente significa ascensão de íons por difusão ou advecção ao longo de estruturas rúpteis, a partir das unidades permianas subjacentes (Grupo Passa Dois). Nestas condições, o equilíbrio geoquímico das águas favorece a precipitação de carbonato (calcita) e aluminossilicato (analcima).

23) Toda a porção confinada do aqüífero apresenta águas em equilíbrio geoquímico com esmectita e calcita. Na Área 4, no noroeste do estado, e na Área 2, ao sul, as águas apresentam excesso de sílica dissolvida devido provavelmente à maior intensidade de lixiviação de arcabouço instável (feldspato e mica). 


\section{REFERÊNCIAS BIBLIOGRÁFICAS}

ALMEIDA, F.F.M. \& BARBOSA, O. 1953. Geologia das quadrículas de Piracicaba e Rio Claro, Estado de São Paulo. Bol. Div. Geol. Min., DNPM, 143: 1-96.

ALMEIDA, F.F.M. 1954. Botucatu, um deserto triássico da América do Sul. Div. Geol. Min., DNPM, Notas Preliminares e Estudos, 86:1-21.

ANJOS, S.M.C. dos; DE ROS, L.F.; SOUZA, R.S.; SILVA, C.M.A.; SOMBRA, C.L. 2000. Depositional and diagenetic controls on the reservoir quality of Lower Cretaceous Pendência sandstones, Potiguar rift basin, Brazil. AAPG Bulletin $84: 1719-1742$.

ARAÚJO, C.C. 2003. Gênese das ocorrências de arenito asfáltico da borda leste da Bacia do. Paraná, SP. São Paulo, IG-USP, 135 p. (Tese de Doutoramento).

ARAÚJO, L.M.; FRANÇA, A.B.; POTTER, P.E. 1999. Hydrogeology of the Mercosul aquifer system in the Paraná and Chaco-Paraná Basins, South America, and comparison with the Navajo-Nugget aquifer system, USA. Hydrogeology Journal, 7: 317-336.

ASSINE, M.L. 1993. O fluvial e o eólico na Formação Pirambóia. In: Simpósio SulBrasileiro de Geologia, 5, Curitiba, 1993. Resumos, p. 53-54.

ASSINE, M.L.; PIRANHA, J.M.; CARNEIRO, C.D.R. 2004. Os paleodesertos Pirambóia e Botucatu. In: V. Mantesso-Neto; A. Batorelli, C.D.R. Carneiro, B.B. Brito-Neves (eds.) Geologia do Continente Sul-Americano: Evolução da obra de Fernando Flávio Marques de Almeida, São Paulo, Editora Beca, p. 77-92.

BIGARELLA, J.J. \& SALAMUNI, R. 1961. Early Mesozoic wind patterns as suggested by dune bedding in the Botucatu Sandstones of Brazil and Uruguay. Geol. Soc. of America Bull. 72: 1089-1106.

BIGARELLA, J.J. 1973. Paleocorrentes e deriva continental (Comparação entre América do Sul e África). Boletim Paranaense de Geociências 31:141-224.

BJORLYKKE, K. \& AAGAARD, P. 1992. Clay minerals in the North Sea. In: D.W. Houseknecht \& E.D. Pittman (eds.) Origin, diagenesis, and petrophisics of clay minerals in sandstones, SEPM Special Publication 47, p. 65-80.

BÓSIO, N.J. 1973. Geologia da Área de São Pedro, SP. Rio Claro, SP, Fac. Filos. Ciências e Letras, 125 p. (Tese de Doutoramento)

CAETANO-CHANG, M.R. \& WU, F.T. 1992a. A composição faciológica das formações Pirambóia e Botucatu no centro-leste paulista e a delimitação do contato entre as unidades. In: SIMP. CRONOESTR. DA BACIA DO PARANÁ, 1. Rio Claro, 1992. Resumos, IGCE-UNESP, p. 93.

CAETANO-CHANG, M.R. \& WU, F.T. 1992b. Bacia do Paraná: Formações Pirambóia e Botucatu. In: CONGR. BRAS. GEOL., 37. São Paulo, 1992. Roteiro de Excursão. SBG, vol. 2.

CAETANO-CHANG, M.R. \& WU, F.T. 1993a. A composição faciológica das formações Pirambóia e Botucatu no centro-leste paulista e delimitação do contato entre as unidades. In: Simpósio de Cronoestratigrafia da Bacia do Paraná, 1, Rio Claro, 1993, Boletim de Resumos Expandidos, p. 93. 
CAETANO-CHANG, M.R. \& WU, F.T. 1993b. A Formação Pirambóia na região de Anhembi (SP), com base em dados de subsuperfície. In: Simpósio de Geologia do Sudeste, 3, Rio de Janeiro, 1993, Boletim de Resumos, p.

CAETANO-CHANG, M.R. \& WU, F.T. 1994. Afloramento-modelo da Formação Pirambóia. Geociências, 13(2):371-385.

CAETANO-CHANG, M.R. 1992. Estado d'arte dos conhecimentos sedimentológicos/estratigráficos das formações Pirambóia e Botucatu no Estado de São Paulo. In: SIMP. CRONOESTR. DA BACIA DO PARANÁ, 1. Rio Claro, 1992. Resumos, IGCE-UNESP, p. 84-85.

CAETANO-CHANG, M.R. 1997. A Formação Pirambóia no centro-leste do Estado de São Paulo. Rio Claro, IGCE-UNESP, 196 p. (tese de Livre-Docência).

CAETANO-CHANG, M.R.; WU, F.T.; BRIGHETI, J.M.P. 1991. Caracterização eólica de arenitos da Formação Pirambóia, proximidades de São Pedro (SP). In: Simpósio de Geologia do Sudeste, 1, São Paulo, 1991, Atas, vol. 2, p. 53-58.

CAMPOS, H.C.N.S. 1993. Caracterização e cartografia das províncias hidrogeoquímicas do Estado de São Paulo. São Paulo, IG-USP, 177 p. (Tese de Doutorado)

CARVALHO, A.M.V. 1954. Contribuição ao estudo petrográfico do Arenito Botucatu no Estado de São Paulo. Bol. Soc. Bras. Geol. 3(1): 51-72.

CHANG, H.K. 2006. Utilização atual do Aqüífero Guarani. In: Jornada Estadual Aqüífero Guarani, 1, Botucatu, SP, 2006 (cd-rom).

CHOQUETTE, P.W. \& PRAY, L. 1970. Geologic nomenclature and classifications of porosity in sedimentary carbonates. AAPG Bull., 54:207-250.

CRABTREE Jr, S.; EHRLICH, R.; PRINCE, C. 1984. Evaluation of strategies for segmentation of blue-dyed pores in thin sections of reservoir rocks. Computer Vision, Graphics, and Image Processing, 28: 1-18.

DE ROS. L.F.; SGARBI, G.N.C.; MORAD, S. 1994. Multiple authigenesis of Kfeldspar in sandstones: evidence from the Cretaceous Areado Formation, São Francisco Basin, Central Brazil. Jour. Sedim. Res., A64:778-787.

DIXON, S.A.; SUMMERS, D.M.; SURDAM, R.C. 1989. Diagenesis and preservation of porosity in Norphlet Formation (Upper Jurassic), Southern Alabama. AAPG Bull., 73:707-728.

DONATTI, L.M. 2002. Faciologia, proveniência e paleogeografia das formações Pirambóia e Botucatu no Estado do Paraná. São Paulo, IG-USP, 135 p. (Dissertação de Mestrado)

DONATTI, L.M.; SAWAKUCHI, A.O.; GIANNINI, P.C.F.; FERNANDES, L.A. 2001. The Pirambóia-Botucatu Succession in São Paulo and Paraná States: different eolian systems in the Paraná Basin. Rio de Janeiro, Anais da Academia Brasileira de Ciências, 73(3):465.

DOTT, R.H., Jr. 1964. Wacke, graywacke and matrix - what approach to immature sandstone classification? J. Sedim. Petrol. 34(3):625-632.

EHRLICH, R.; CRABTREE, S.J.; HORKOWITZ, K.O.; HORKOWITZ, J.P. 1991. Petrography and reservoir physics I: Objective classification of reservoir porosity. AAPG Bull. 75(10):1547-1562. 
EHRLICH, R.; KENNEDY, S.K.; CRABTREE, S.J.; CANNON, R.L. 1984. Petrographic image analysis, I. Analysis of reservoir pore complexes. Jour. Sedim. Petrol., 54(4): 1365-1378.

ERHENBERG, S.N. 1995. Relationship between diagenesis and reservoir quality in sandstones of the Garn Formation, Haltenbanken, mid-Norwegian Continental Shelf. AAPG Bull., 74:1538-1558.

FOLK, R.L. 1965. Petrology of sedimentary rocks. Austin, Texas University, 154 p.

FOLK, R.L. 1968. Petrology of sedimentary rocks. Austin, Hemphill Publ. Co. 170p

FRAGA, C.G. 1992. Origem do fluoreto em águas subterrâneas dos sistemas aqüíferos Botucatu e Serra Geral da Bacia do Paraná. São Paulo, IG-USP, 178 p. (Tese de Doutorado)

FRANÇA, A.B.; ARAÚJO, L.M.; MAYNARD, J.B.; POTTER, P.E. 2003. Secondary porosity formed by deep meteoric leaching: Botucatu eolianite, southern South America. AAPG Bull., 87: 1073-1082.

GASTMANS, D. \& CHANG, H.K. 2005. Avaliação da hidrogeologia e hidrogeoquímica do Sistema Aqüífero Guarani (SAG) no Estado de Mato Grosso do Sul. Águas Subterrâneas, 19(1):35-48.

GIANNINI, P.C.; FERNANDES, L.A.; DONATTI, L.M.; SAWAKUCHI, A.S.; MORI, E.K.; COIMBRA, A.M. 1999. Rumos de paleoventos na Formação Pirambóia nos estados de São Paulo e Paraná. In: Simpósio de Geologia do Sudeste, 6, São Pedro, 1999, Boletim de Resumos, p. 71.

GIANNINI, P.C.F. 2001. As formações Pirambóia e Botucatu nos estados de São Paulo e Paraná. São Paulo, IG-USP, 143 p. (Relatório final de pesquisa)

GIANNINI, P.C.F.; DONATTI, L.M.; FERNANDES, L.A.; FONSECA, P. L..; SAWAKUCHI, A. O.; RODRIGUES, S.O.; MORI, E. K. 1999. Confronto entre o sistema eólico da costa sul-catarinense e as formações Pirambóia e Botucatu: correlações processo-produto do Quaternário no estudo de rochas mesozóicas. In: CONGR. ASSOC. BRASIL. DE ESTUDOS DO QUATERNÁRIO, 7, Porto Seguro, BA. Anais... (cd). Salvador, Abequa. 3p.

GIANNINI, P.C.F.; SAWAKUCHI, A.O.; FERNANDES, L.A.; DONNATI, L.M. 2004. Paleofluxo sedimentar do sistema deposicional Pirambóia nos estados de São Paulo e Paraná, Bacia do Paraná: estudo baseado em análise estatística de dados azimutais. Rev. Bras. Geociências, 34(2): 282-292.

GILES, M.R. \& MARSHALL. 1986. Constraints on the development of secondary porosity in the subsurface: re-evaluation of processes. Marine and Petroleum Geology, 3:243-255.

HIRATA, R.C.A.; BASTOS, C.R.A.; ROCHA, G.A.; GOMES, D.C.; IRITANI, M.A. 1999. Groundwater pollution risk and vulnerability map of the State of São Paulo, Brazil. Wat. Sci. Tech., 24 : 159-169.

HOUNSLOW, A. W. 1995. Water Quality Data. Analysis and Interpretation. Lewis Publishers, $397 \mathrm{p}$.

HOUSEKNECHT, D.W. 1987. Assessing the relative importance of compaction processes and cementation to reduction of porosity in sandstones. AAPG Bull., 6: 633-642. 
KAHN, J.S. 1956. The analysis and distribution of the properties of packing in sandsize sediments: 1 . On the measurement of packing in sandstones. Journal of Geology, 64: 385-395.

KOCUREK, G. \& HAVHOLM, K.G. 1993. Eolian sequence stratigraphy - A conceptual framework. In: P. Weimer \& H.W. Possamentier (eds.) Siliciclastic sequence stratigraphy, AAPG Memoir 58, p.393-409.

LAVINA, E.L. 1991. Geologia sedimentar e paleogeografia do Neopermiano e Eotriássico (Intervalo Kazaniano-Scythiano) da Bacia do Paraná. Porto Alegre, IG-UFRGS, 2 vol., 332 p. (Tese de Doutorado)

LEINZ, V. 1938. Estudos petrográficos sobre os arenitos de Anhembi. Mineração e Metalurgia, 2(11): 340-342.

LUNDEGARD, P.D. 1992. Sandstone porosity loss, a "big picture" view of the importance of compaction. Jour. Sedim. Petrol., 62: 250-260.

MARASCHIN, A.J.; MIZUSAKI, A.M.; DE ROS, L.F. 2004. Near -surface K-Feldspar precipitation in Cretaceous Sandstones from the Potiguar Basin, Northeasthern Brazil. J ournal of Geology, 112:317-334.

MATOS, S.L.F. \& COIMBRA, A.M. 1997. Sucessão de fácies na Camada Porangaba, Grupo Passa Dois, Estado de São Paulo. Rev. Bras. Geociências, 27(4): 377386.

MATOS, S.L.F. 1995. O contato entre o Grupo Passa Dois e a Formação Pirambóia na borda leste da Bacia do Paraná no Estado de São Paulo. São Paulo, IGUSP, 110 p. (Dissertação de Mestrado)

MCBRIDE, E.F. 1989. Quartz cement in sandstones: a review. Earth-Science Reviews, 26: 69-112.

MCBRIDE, E.F.; LAND, L.S.; MACK, L.E. 1987. Diagenesis of eolian and fluvial feldspathic sandstones, Norphlet Formation (Upper Jurassic), Rankin County, Mississipi, and Mobile County, Alabama. AAPG Bull., 9: 1019-1034.

MCBRIDE, M. B. - 1994 - Environmental Chemistry of Soils. Oxford University Press, $406 \mathrm{p}$.

MCKINLEY, J.M.; WORDEN, R.H.; RUFFEL, A.H. 2003. Smectite in sandstones: a review of the controls on occurrence and behaviour during diagenesis. In: R.H. Worden \& S. Morad (eds.) Clay Mineral Cements in Sandstones, IAS Special Publication 34, p.109-128.

MENG, S.X. \& MAYNARD, J.B. 2001. Use of statistical analysis to formulate conceptual models of geochemical behavior: water chemical data from Botucatu aquifer in São Paulo state, Brazil. Journal of Hydrology, 250: 7897.

MILANI, E.J.; FRANÇA, A.B.; SCHNEIDER, R.L. 1994. Bacia do Paraná. Bol. Geoc. Petrobras, 8(1):69-82.

MORAD, S.; BERGAN, M.; KNARUD, R.; NYSTUEN, J.P. 1990. Albitization of detrital plagioclase in Triassic reservoir sandstones from the Snorre Field, Norwegian North Sea. Jour. Sedim. Petrol., 60:411-425.

MORAD, S.; KETZER, J.M.; DE ROS, L.F. 2000. Spatial and temporal distribution of diagenetic alteration insiliciclastic rocks: implications for mass transfer in sedimentary basin. Sedimentology, 47:95-120. 
MORAES, M.A.S. \& DE ROS, L.F. 1990. Infiltrated clays in fluvial Jurassic sandstones of Recôncavo Basin, northeastern Brazil. Jour. Sedim. Petrol., 60: 809-819.

MORAES, M.A.S. \& DE ROS, L.F. 1992. Depositional, infiltrated, and authigenic clays in fluvial sandstones of the Jurassic Sergi Formation, Recôncavo Basin, northeastern Brazil. In: D.W. Houseknecht \& E.D. Pittman (eds.) Origin, Diagenesis, and Petrophysics of Clay Minerals in Sandstones, SEPM Special Publication 47, p.197-208.

MOWERS, T.T. \& BUDD, D.A. 1996. Quantification of porosity and permeability reduction due to calcite cementation using computer-assisted petrographic Image Analysis Techniques. AAPG Bull., 80(3): 309-322.

NORTHFLEET, A.P.; MEDEIROS, R.A.; MULHMANN, H. 1969. Reavaliação dos dados geológicos da Bacia do Paraná. Bol. Téc. Petrobras, 12(3): 291-346.

OLIVEIRA, R.A.R.N. 2001. Arenitos silicificados das formações Pirambóia e Botucatu no Estado de São Paulo: processos geradores e aspectos geomorfológicos associados. São Paulo, IG-USP, 33 p., 6 pranchas (Monografia de Trabalho de Formatura, TF-2001/33).

PARAGUASSU, A.B. 1968. Contribuição ao estudo da Formação Botucatu sedimentos aquosos, estruturas sedimentares e silicificação. São Carlos, Esc. Eng-USP, 131 p. (Tese de Doutorado)

PARAGUASSU, A.B. 1972. Experimental silicification of sandstone. GSA Bull., 83(9):2853-2858.

PARKHUST, D.L. 1995. User's guide to PHREEQC - a computer program for speciation, reaction-path, advective-transport, and inverse geochemical calculations. USGS Water Resource Invest. Rep, p. 95-4227.

PEREIRA, C.A.F. 1991. Petrologia e diagênese dos arenitos da Unidade Açu-4 da Formação Açu (Ksup) ao longo da Linha de Charneira de Areia Branca, Bacia Potiguar, Rio Grande do Norte. Ouro Preto, Escola de Minas, 158 p. (Dissertação de Mestrado)

PERROTA, M.M.; SALVADOR, E.D.; LOPES R.C.; D'AGOSTINO, L.Z.; PERRUFO, N.; GOMES, S.D.; SACHS, L.L.B.; MEIRA, V.T.; LACERDA FILHO, J.V. 2005. Mapa geológico do Estado de São Paulo, escala 1:750.000. Programa Levantamentos Geológicos Básicos do Brasil, CPRM, SP.

PETTIJOHN, F.J.; POTTER, P.E.; SIEVER, R. 1973. Sand and sandstone. Heidelberg, Springer-Verlag, $618 \mathrm{p}$.

PITTMAN, E.D.; LARESE, R.E.; HEALD, M.T. 1992. Clay coats: Occurrence and relevance to preservation of porosity in sandstones. In: D.W. Houseknecht \& E.D. Pittman (eds.) Origin, diagenesis, and petrophisics of clay minerals in sandstones, SEPM Special Publication 47, p. 241-255.

PORTUGAL, W. 2006. Investigação hidrogeoquímica do Sistema Aqüífero Guarani no Estado de São Paulo. São Paulo, IG-USP, 45 p (Monografia de Trabalho de Formatura)

POWERS, M.C. 1953. Comparison chart for visual estimation of roundness. Jour. Sedim. Petrol., 23:117-119.

RAMOS, A.N. \& FORMOSO, M.L.L. 1975. Argilominerais das rochas sedimentares da Bacia do Paraná. Rio de Janeiro, Ciência - Técnica - Petróleo, Seção Exploração de Petróleo, 9, 72p. e anexos. 
REBOUÇAS, A.C. 1976. Recursos hídricos subterrâneos da Bacia do Paraná: análise de pré-viabilidade. São Paulo, IG-USP, 176 p. (Tese de Livre-Docência)

RICCOMINI, C. 1995. Tectonismo gerador e deformador dos depósitos sedimentares pós-gondvânicos da porção centro-oriental do Estado de São Paulo e áreas vizinhas. São Paulo, IG-USP, 100 p. (Tese de Livre-Docência)

RICCOMINI, C.; GIMENEZ FILHO, A.; ALMEIDA, F.F.M. 1984. Considerações sobre a estratigrafia do Permo-Triássico na região da Serra do Cadeado, Paraná. In: CONGR. BRAS. GEOL., 33. Rio de Janeiro, 1984. Anais. Rio de Janeiro, SBG, v.2, p. 754-763.

ROCHA, G. 1997. O grande manancial do Cone Sul. Estudos Avançados, 11: 191212.

ROHN, R. 1994. Evolução ambiental da Bacia do Paraná durante o Neopermiano no leste de Santa Catarina e do Paraná. São Paulo, IG-USP, 2 vol, 386 p. (Tese de Doutoramento)

SALAMUNI, R. \& BIGARELLA, J.J. 1967. The Botucatu Formation. In: J.J. Bigarella; R.D. Becker; J.D. Pinto (eds.) Problems in Brazilian Gondwana Geology. Curitiba, UFPR, p. 197-206.

SAWAKUCHI, A.O. 2000. Dinâmica e contexto paleogeográfico do Sistema Deposicional Eólico Pirambóia no Estado de São Paulo. São Paulo, IG-USP, 38 p. (Monografia de Trabalho de Formatura, TF-2000/2)

SCHERER, C.M.S. 2000. Eolian dunes of the Botucatu Formation (Cretaceous) in southernmost Brazil: morphology and origin. Sedimentary Geology, 137:6384.

SCHMIDT, V. \& MCDONALD, D.A. 1979. Texture and recognition of secondary porosity in sandstones. SEPM Special Publication, 26: 209-225.

SCHNEIDER, R.L.; MÜLHMANN, H.; TOMMASI, E.; MEDEIROS, R.A.; DAEMON, R.F.; NOGUEIRA, A.A. 1974. Revisão estratigráfica da Bacia do Paraná. In: CONGR. BRAS. GEOL., 28. Porto Alegre, 1974. Anais. Porto Alegre, SBG, v.1, p. 41-65.

SILVA, R.B.G. 1983. Estudo hidroquímico e isotópico das águas subterrâneas do Aqüífero Botucatu no Estado de São Paulo. São Paulo, IG-USP, 133 p. (Tese de Doutorado)

SOARES, P.C. 1973. O Mesozóico gondwânico no Estado de São Paulo. Rio Claro, Fac. Filos. Ciências e Letras, 153 p. (Tese de Doutoramento)

SOARES, P.C. 1975. Divisão estratigráfica do Mesozóico no Estado de São Paulo. Rev. Bras. Geociências, 5(4):229-251

SRACEK, O. \& HIRATA, R. 2002. Geochemical and stable isotopic evolution of the Guarani Aquifer System in the state of São Paulo, Brazil. Hydrogeology Journal, 10: 643-655.

SUGUIO, K.; COIMBRA, A.M.; GUARDADO, L.R. 1974. Correlação sedimentológica de arenitos da Bacia do Paraná. Bol. IG-USP, 5:85-116.

SURDAM, R.C.; BOESE, S.W.; CROSSEY, L.J. 1984. The chemistry of secondary porosity. In: D.A. McDonald \& R.C. Surdam (eds.) Clastic Diagenesis, AAPG Memoir 37, p. 127-151. 
TAKAHASHI, A. 2005. Aqüífero Guarani. In: Conselho Estadual de Recursos Hídricos, Mapa de Águas Subterrâneas do Estado de São Paulo. São Paulo, DAEE/ IG-SMA / IPT / CPRM, p. 39-45.

THIRY, M. \& MILLOT, G. 1987. Mineralogical forms of silica and their sequence of formation in silcretes. J our. Sedim. Petrol., 57:343-352.

TURNER S.; REGELOUS, M.; KELLEY, S.; HAWKESWORTH, C.; MANTOVANI, M. 1994. Magmatism and continental break-up in the South Atlantic: high precision ${ }^{40} \mathrm{Ar}-{ }^{39} \mathrm{Ar}$ geochronology. Earth Planet. Sci. Lett., 121:333-348.

WALKER, R.G. 1980. Facies and Facies Models. General introduction. In: R.G. Walker (ed.) Facies Models, Geological Association of Canada, p. 1-7.

WALKER, T.R. 1967. Formation of red beds in modern and ancient deserts. GSA Bull., 78:353-368.

WALKER, T.R. 1979. Red color in dune sand. In: E.D. McKee, ed., A Study of Global Sand Seas, USGS Professional Paper 1052, p.62-81.

WASHBURNE, C.W. 1930. Petroleum geology of State of São Paulo. Bol. Com. Geogr. Geol. do Est. de São Paulo, 22:1-282.

WAUGH, B. 1978. Authigenic K-feldspar in British Permo-Triassic sandstones. Journal of Geological Society of London, 135:51-56.

WILLIAMS, L. A.; PARKS, G. A.; CREAR, D. A. 1985, Silica Diagenesis, I. Solubility Controls: Jour. Sedim. Petrol., 55:301-311.

WILSON, M.D. 1992. Inherited grain-rimming clays in sandstones from eolian and shelf environments: their origin and control on reservoir properties. In: D.W. Houseknecht \& E.D. Pittman (eds.) Origin, diagenesis, and petrophisics of clay minerals in sandstones, SEPM Special Publication 47, p. 209-225.

WORDEN, R.H. \& MORAD, S. 2000. Quartz cementation in oil fields sandstones: a review of the key controversies. In: R.H. Worden and S. Morad (eds.) Quartz Cementation in Sandstones, IAS Special Publication 29, p. 1-20.

WU, F.T. \& CAETANO-CHANG, M.R. 1992a. Estudo mineralógico dos arenitos das formações Pirambóia e Botucatu no centro-leste do Estado de São Paulo. Rev. IG, 13(1):58-68.

WU, F.T. \& CAETANO-CHANG, M.R. 1992b. Estudo petrográfico de arenitos da Formação Pirambóia a partir de testemunhos de poços na região de Anhembi (SP). In: CONGR. BRAS. GEOL., 37. São Paulo, 1992. Boletim de Resumos Expandidos.São Paulo, SBG, v.2, p. 428-429.

WU, F.T. \& SOARES, P.C. 1974. Minerais pesados nas formações Pirambóia e Botucatu. In: CONGR. BRAS. GEOL., 28. Porto Alegre, 1974. Anais. Porto Alegre, SBG, v.2, p. 119-127.

YAMAMOTO, J.K.; FAIRCHILD, T.R.; BOGGIANI, P.C.; MONTANHEIRO, T.J.; ARAÚJO, C.C.; KIYOHARA, P.K.; MATOS, S.F.L.; SOARES, P.C. 2005. A record of Permian subaqueous vent activity in southeastern Brazil. Nature, 438:205-207.

ZALÁN, P.V.; WOLFF, S.; CONCEIÇÃO, J.C.J.; ASTOLFI, M.A.M.; VIEIRA, I.S. ; APPI, V.T.; ZANOTTO, O.A. 1987. Tectônica e Sedimentação da Bacia do Paraná. In: SIMP. SUL-BRAS. GEOL., 3. Curitiba, 1987. Atas. Curitiba, SBG, v.1, p. 441-477. 


\section{ANEXOS}

Tabela 1 - Relação dos poços revisados/amostrados e pontos de afloramento descritos.

Tabela 2 - Dados petrográficos (1).

Tabela 3 - Dados petrográficos (2).

Tabela 4 - Dados petrográficos (3). 
Tabela 1 - Relação dos poços revisados/amostrados e pontos de afloramento descritos.

\begin{tabular}{|c|c|c|c|c|c|c|c|c|c|c|c|c|c|c|c|c|c|}
\hline Ref. & LONG & LAT & Município & cota-BP & $\begin{array}{l}\text { prof- } \\
\text { final }\end{array}$ & $\begin{array}{l}\text { esp- } \\
\text { conf. }\end{array}$ & $\begin{array}{l}\text { esp- } \\
\text { SG }\end{array}$ & $\begin{array}{l}\text { prof-tp- } \\
\text { BOT }\end{array}$ & \begin{tabular}{|l} 
prof-tp- \\
PirSup
\end{tabular} & $\begin{array}{l}\text { prof-tp- } \\
\text { PIR }\end{array}$ & $\begin{array}{l}\text { prof-tp- } \\
\text { PD }\end{array}$ & $\begin{array}{l}\text { esp- } \\
\text { BOT }\end{array}$ & $\begin{array}{c}\text { esp- } \\
\text { PirSup }\end{array}$ & $\begin{array}{l}\text { esp- } \\
\text { PIR }\end{array}$ & $\begin{array}{l}\text { esp- } \\
\text { PIRt }\end{array}$ & $\begin{array}{l}\text { esp- } \\
\text { Gua }\end{array}$ & Aquífero \\
\hline 1 & -49.238 & -22.881 & $\begin{array}{c}\text { Águas de Sta. } \\
\text { Bárbara }\end{array}$ & 560.00 & 120.00 & 104.00 & 104.00 & 104.00 & & & & $>16.00$ & & & & $>16.00$ & BOT \\
\hline 2 & -48.963 & -22.472 & Agudos & 620.00 & 182.80 & 134.00 & 0.00 & 134.00 & & & & $>48.80$ & & & & $>48.80$ & BOT \\
\hline 3 & -48.990 & -22.459 & Agudos & 591.00 & 206.00 & 114.00 & 10.00 & 114.00 & & & & $>92.00$ & & & & $>92.00$ & ВОт \\
\hline 4 & -48.108 & -21.722 & $\begin{array}{c}\text { Américo } \\
\text { Brasiliense }\end{array}$ & 680.00 & 414.00 & 346.00 & 131.00 & 215.00 & 346.00 & & & 131.00 & 64.00 & & & $>195.00$ & BOT/PIRf \\
\hline 5 & -51.378 & -20.883 & Andradina & 410.00 & 1030.00 & 805.00 & 700.00 & 805.00 & -395.00 & & & & & & & $>135.00$ & BOT/PIR \\
\hline 6 & -50.445 & -21.165 & Araçatuba & 410.00 & 1200.00 & 967.00 & 917.00 & 967.00 & 1102.00 & 1172.00 & & 123.00 & 70.00 & $>28.00$ & $>98.00$ & $>221.00$ & BOT/PIRf/PIRe \\
\hline 7 & -50.367 & -21.131 & Araçatuba & 362.50 & 969.00 & 944.00 & 923.70 & 944.00 & & & & $>25.00$ & & & & $>25.00$ & BOT \\
\hline 8 & -48.172 & -21.800 & Araraquara & 625.00 & 365.00 & 106.50 & 90.00 & 106.50 & & & 365.00 & & & & & 258.50 & BOT/PIR \\
\hline 9 & -48.184 & -21.812 & Araraquara & 600.00 & 338.00 & 80.00 & 80.00 & 80.00 & 324.00 & & & 234.00 & $>14.00$ & & $14.00>$ & $>248.00$ & BOT/PIRf \\
\hline 10 & -48.223 & -21.810 & Araraquara & 505.00 & 125.00 & 10.00 & 10.00 & 125.00 & & & & $>125.00$ & & & & $>125.00$ & BOT \\
\hline 11 & -48.135 & -21.779 & Araraquara & 640.00 & 381.00 & 144.00 & 144.00 & 144.00 & 344.00 & & & 114.00 & $>39.00$ & & $>39.00$ & $>153.00$ & BOT/PIRf \\
\hline 12 & -48.212 & -21.786 & Araraquara & 600.00 & 384.00 & 190.00 & 190.00 & 190.00 & 336.00 & & & 138.00 & $>46.00$ & & $>46.00$ & $>184.00$ & BOT/PIRf \\
\hline 13 & -48.190 & -21.801 & Araraquara & 645.00 & 197.00 & 194.00 & 194.00 & 194.00 & & & & $>3.00$ & & & & $>3.00$ & BOT \\
\hline 14 & -48.158 & -21.799 & Araraquara & 600.00 & 330.00 & 98.00 & 98.00 & 98.00 & 298.00 & & & 200.00 & $>32.00$ & & $>32.00$ & $>232.00$ & BOT/PIRf \\
\hline 15 & -48.565 & -20.523 & Barretos & 575.00 & 1014.00 & 814.00 & 745.00 & 814.00 & & 879.00 & & 62.00 & 0.00 & $>62.00$ & $>62.00$ & $>124.00$ & BOT/PIRe \\
\hline 16 & -48.591 & -20.527 & Barretos & 575.00 & 990.00 & 824.00 & 750.00 & 824.00 & 910.00 & 938.00 & & 66.00 & 28.00 & $>52.00$ & $>80.00$ & $>166.00$ & BOT/PIRe \\
\hline 17 & -48.149 & -21.192 & Barrinha & 520.00 & 410.00 & 280.00 & 247.00 & 280.00 & 358.00 & & & 78.00 & $>52.00$ & & $>52.00$ & $>130.00$ & BOT/PIRf \\
\hline 18 & -47.531 & -20.865 & Batatais & 700.00 & 265.00 & 104.00 & 104.00 & 104.00 & 132.00 & 148.00 & & 32.00 & 16.00 & $>117.00$ & $>101.00$ & $>161.00$ & BOT/PIRf/PIRe \\
\hline 19 & -47.591 & -20.892 & Batatais & 840.00 & 496.00 & 324.00 & 324.00 & 324.00 & & 420.00 & & 96.00 & 0.00 & $>76.00$ & $>76.00$ & $>172.00$ & BOT/PIRe \\
\hline 20 & -49.036 & -22.320 & Bauru & 510.00 & 291.00 & 54.00 & 0.00 & 54.00 & & 78.00 & 288.00 & 20.00 & 0.00 & 210.00 & 210.00 & 230.00 & BOT/PIRe \\
\hline 21 & -49.133 & -22.333 & Bauru & 520.00 & 187.00 & 86.00 & 0.00 & 86.00 & & 150.00 & 173.00 & 64.00 & 0.00 & 23.00 & 23.00 & 87.00 & BOT/PIRe \\
\hline 22 & -49.080 & -22.274 & Bauru & 533.50 & 406.00 & 146.00 & 54.00 & 146.00 & 272.00 & & & 96.00 & $>134.00$ & & $>134.00$ & $>224.00$ & BOT/PIRf \\
\hline 23 & -49.034 & -22.320 & Bauru & 515.00 & 310.00 & 60.00 & 0.00 & 60.00 & 80.00 & 220.00 & 308.00 & 20.00 & 140.00 & 88.00 & 228.00 & 248.00 & BOT/PIRf/PIRe \\
\hline 24 & -49.111 & -22.338 & Bauru & 580.00 & 276.00 & 190.00 & 0.00 & & & 190.00 & 192.00 & 0.00 & 0.00 & 2.00 & 2.00 & 2.00 & PIRe \\
\hline 25 & -49.075 & -22.317 & Bauru & 500.00 & 206.00 & 70.00 & 0.00 & 70.00 & 94.00 & & 198.00 & 24.00 & 104.00 & 0.00 & 104.00 & 128.00 & BOT/PIRf \\
\hline 26 & -49.061 & -22.334 & Bauru & 560.00 & 150.00 & 104.00 & 0.00 & 104.00 & & & & $>46.00$ & & & & $>46.00$ & BOT \\
\hline 27 & -49.050 & -22.333 & Bauru & 560.00 & 307.00 & 100.00 & 0.00 & & 100.00 & 170.00 & 302.00 & 0.00 & 70.00 & 132.00 & 202.00 & 202.00 & PIRf/PIRe \\
\hline 28 & -49.127 & -22.314 & Bauru & 580.00 & 286.00 & 133.00 & 0.00 & & 133.00 & 150.00 & 284.00 & 0.00 & 17.00 & 118.00 & 135.00 & 135.00 & PIRf/PIRe \\
\hline
\end{tabular}




\begin{tabular}{|c|c|c|c|c|c|c|c|c|c|c|c|c|c|c|c|c|c|}
\hline Ref. & LONG & LAT & Município & cota-BP & $\begin{array}{l}\text { prof- } \\
\text { final }\end{array}$ & $\begin{array}{l}\text { esp- } \\
\text { conf. }\end{array}$ & esp-SG & \begin{tabular}{|c|} 
prof-tp- \\
BOT \\
\end{tabular} & \begin{tabular}{|l|} 
prof-tp- \\
PirSup \\
\end{tabular} & \begin{tabular}{|c|} 
prof-tp- \\
PIR \\
\end{tabular} & \begin{tabular}{|c|} 
prof-tp- \\
PD \\
\end{tabular} & $\begin{array}{l}\text { esp- } \\
\text { BOT }\end{array}$ & \begin{tabular}{|c|} 
esp- \\
PirSup
\end{tabular} & esp-PIR & $\begin{array}{l}\text { esp- } \\
\text { PIRt }\end{array}$ & $\begin{array}{l}\text { esp- } \\
\text { Gua }\end{array}$ & Aquífero \\
\hline 29 & -48.981 & -22.325 & Bauru & 590.00 & 327.00 & 263.00 & 141.00 & 263.00 & & & & $>63.00$ & & & & $>63.00$ & BOT \\
\hline 30 & -49.013 & -22.321 & Bauru & 520.00 & 414.00 & 114.00 & 18.00 & 114.00 & 216.00 & 342.00 & & 102.00 & 126.00 & $>72.00$ & $>198.00$ & $>300.00$ & BOT/PIRf/PIRe \\
\hline 31 & -49.114 & -22.309 & Bauru & 560.00 & 322.00 & 136.00 & 0.00 & 136.00 & 142.00 & 186.00 & 314.00 & 6.00 & 44.00 & 128.00 & 172.00 & 178.00 & BOT/PIRf/PIRe \\
\hline 32 & -49.034 & -22.294 & Bauru & 510.00 & 473.00 & 219.00 & 159.00 & 219.00 & 262.00 & 378.00 & 470.00 & 43.00 & 116.00 & 92.00 & 208.00 & 251.00 & BOT/PIRf/PIRe \\
\hline 33 & -48.451 & -20.942 & Bebedouro & 590.00 & 924.00 & 790.00 & 707.00 & 790.00 & & & & $>96.00$ & & & & $>96.00$ & BOT \\
\hline 34 & -48.387 & -22.002 & $\begin{array}{c}\text { Boa Esperança } \\
\text { do Sul }\end{array}$ & 540.00 & 96.00 & 0.00 & 0.00 & 0.00 & 46.00 & & & 46.00 & $>50.00$ & & $>50.00$ & $>96.00$ & BOT/PIRf \\
\hline 35 & -47.636 & -20.983 & Brodowsqui & 800.00 & 450.00 & 266.00 & 266.00 & 266.00 & 354.00 & 412.00 & & 88.00 & 57.00 & $>38.00$ & $>95.00$ & $>183.00$ & BOT/PIRf/PIRe \\
\hline 36 & -48.960 & -21.123 & Catanduva & 500.00 & 770.00 & 464.00 & 366.00 & 464.00 & 636.00 & 730.00 & & 172.00 & 94.00 & $>38.00$ & 132.00 & 304.00 & BOT/PIRf/PIRe \\
\hline 37 & -48.549 & -20.660 & Colina & 550.00 & 933.00 & 720.00 & 682.00 & 720.00 & 852.00 & 858.00 & & 132.00 & 6.00 & $>72.00$ & $>78.00$ & $>210.00$ & BOT/PIRf/PIRe \\
\hline 38 & -48.381 & -22.376 & Dois Córregos & 722.00 & 558.00 & 366.00 & 338.00 & 366.00 & 398.00 & 528.00 & & 32.00 & 130.00 & $>30.00$ & $>160.00$ & $>192.00$ & BOT/PIRf/PIRe \\
\hline 39 & -50.223 & -20.282 & Fernandópolis & 480.00 & 1680.00 & 1340.00 & 1210.00 & 1340.00 & 1397.00 & 1478.00 & 1653.00 & 57.00 & 81.00 & 175.00 & 256.00 & 313.00 & BOT/PIRf/PIRe \\
\hline 40 & -50.183 & -20.251 & Fernandópolis & 436.00 & 1604.00 & 1269.00 & 1226.00 & 1269.00 & 1302.00 & 1353.00 & 1601.00 & 33.00 & 51.00 & 248.00 & 197.00 & 230.00 & BOT/PIRf/PIRe \\
\hline 41 & -48.318 & -20.319 & Guaíra & 520.00 & 740.00 & 506.00 & 506.00 & 506.00 & & 600.00 & & 94.00 & 0.00 & $>140.00$ & $>140.00$ & $>234.00$ & BOT/PIRe \\
\hline 42 & -47.819 & -20.424 & Guará & 590.00 & 436.00 & 286.00 & 286.00 & 286.00 & & & & $>150.00$ & & & & $>150.00$ & BOT \\
\hline 43 & -48.223 & -21.355 & Guariba & 590.00 & 600.00 & 310.00 & 286.00 & 310.00 & 388.00 & 580.00 & & 78.00 & 164.00 & $>20.00$ & $>212.00$ & $>262.00$ & BOT/PIRf/PIRe \\
\hline 44 & -48.000 & -21.950 & Ibaté & 840.00 & 338.00 & 162.00 & 104.00 & 162.00 & & 254.00 & & 92.00 & 0.00 & $>84.00$ & $>84.00$ & $>176.00$ & BOT/PIRe \\
\hline 45 & -48.836 & -21.758 & Ibitinga & 500.00 & 417.00 & 258.00 & 258.00 & 258.00 & & 356.00 & & 98.00 & 0.00 & $>61.00$ & $>61.00$ & $>159.00$ & BOT/PIRe \\
\hline 46 & -48.554 & -22.512 & Igaraçu do Tietê & 480.00 & 300.00 & 102.00 & 102.00 & 102.00 & 224.00 & & & 122.00 & $>76.00$ & & $>76.00$ & $>198.00$ & BOT/PIRf \\
\hline 47 & -48.823 & -21.596 & Itápolis & 510.00 & 500.00 & 288.00 & 230.00 & 288.00 & 424.00 & & & 136.00 & $>76.00$ & & $>76.00$ & $>212.00$ & BOT/PIRf \\
\hline 48 & -48.715 & -22.236 & Itapuí & 450.00 & 158.00 & 148.00 & 148.00 & 148.00 & & & & $>10.00$ & & & & $>10.00$ & BOT \\
\hline 49 & -47.883 & -22.182 & Itirapina & 745.00 & 176.00 & 0.00 & 0.00 & & 0.00 & 148.00 & & 0.00 & 82.00 & $>27.00$ & $>109.00$ & $>109.00$ & PIRf/PIRe \\
\hline 50 & -48.311 & -21.255 & Jaboticabal & 554.00 & 480.00 & 348.00 & 348.00 & 348.00 & & & & $>103.00$ & & & & $>103.00$ & BOT \\
\hline 51 & -48.537 & -22.251 & Jaú & 500.00 & 552.00 & 302.00 & 302.00 & 302.00 & 446.00 & & & 144.00 & $>106.00$ & & $>106.00$ & $>250.00$ & BOT/PIRf \\
\hline 52 & -48.562 & -22.305 & Jaú & 530.00 & 530.00 & 328.00 & 328.00 & 328.00 & 520.00 & & & 192.00 & $>10.00$ & & $>10.00$ & $>202.00$ & BOT/PIRf \\
\hline 53 & -48.575 & -22.308 & Jaú & 595.00 & 608.00 & 404.00 & 404.00 & 404.00 & 578.00 & & & 174.00 & $>27.00$ & & $>27.00$ & $>201.00$ & BOT/PIRf \\
\hline 54 & -48.796 & -22.602 & Lençóis Paulista & 596.00 & 470.00 & 156.00 & 156.00 & 156.00 & & 250.00 & & 82.00 & 82.00 & 108.00 & $>190.00$ & $>272.00$ & BOT/PIRe \\
\hline 55 & -48.814 & -22.580 & Lençóis Paulista & 605.00 & 430.00 & 164.00 & 164.00 & 164.00 & 370.00 & & & 146.00 & $>57.00$ & 60.00 & $>117.00$ & $>263.00$ & BOT/PIRf \\
\hline 56 & -49.769 & -21.672 & Lins & 450.00 & 1042.00 & 632.00 & 502.00 & 632.00 & 870.00 & 891.00 & 1015.00 & 238.00 & 21.00 & 124.00 & 145.00 & 383.00 & BOT/PIRf/PIRe \\
\hline 57 & -49.753 & -21.679 & Lins & 413.40 & 817.00 & 665.00 & 567.00 & 665.00 & & 784.00 & & 119.00 & & & $>33.00$ & $>152.00$ & BOT/PIR \\
\hline 58 & -47.714 & -21.539 & Luiz Antônio & 695.00 & 170.00 & 0.00 & 0.00 & 0.00 & 148.00 & & & 148.00 & $>22.00$ & & $>22.00$ & $>170.00$ & BOT/PIRf \\
\hline
\end{tabular}




\begin{tabular}{|c|c|c|c|c|c|c|c|c|c|c|c|c|c|c|c|c|c|}
\hline Ref. & LONG & LAT & Município & cota-BP & $\begin{array}{l}\text { prof- } \\
\text { final }\end{array}$ & $\begin{array}{l}\text { esp- } \\
\text { conf. }\end{array}$ & Esp-SG & $\begin{array}{l}\text { prof-tp- } \\
\text { BOT }\end{array}$ & $\begin{array}{l}\text { prof-tp- } \\
\text { PirSup }\end{array}$ & $\begin{array}{c}\text { prof-tp- } \\
\text { PIR }\end{array}$ & \begin{tabular}{|l|} 
prof-tp- \\
PD \\
\end{tabular} & $\begin{array}{l}\text { esp- } \\
\text { BOT }\end{array}$ & $\begin{array}{c}\text { esp- } \\
\text { PirSup }\end{array}$ & esp-PIR & $\begin{array}{l}\text { esp- } \\
\text { PIRt }\end{array}$ & $\begin{array}{l}\text { esp- } \\
\text { Gua }\end{array}$ & Aquífero \\
\hline 59 & -48.734 & -22.508 & Macatuba & 500.00 & 228.00 & 30.00 & 30.00 & 30.00 & 140.00 & & & 110.00 & $>88.00$ & & $>88.00$ & $>198.00$ & BOT/PIRf \\
\hline 60 & -49.968 & -22.161 & Marília & 580.00 & 1228.00 & 1008.00 & 723.00 & 1008.00 & & & & & & & & $>220.00$ & BOT/PIR \\
\hline 61 & -48.350 & -21.613 & Matão & 596.00 & 580.00 & 440.00 & 372.00 & 440.00 & 566.00 & & & 124.00 & $>14.00$ & & $>14.00$ & $>138.00$ & BOT/PIRf \\
\hline 62 & -48.378 & -21.605 & Matão & 590.00 & 463.00 & 266.00 & 213.00 & 266.00 & 442.00 & & & 176.00 & $>21.00$ & & $>21.00$ & $>197.00$ & BOT/PIRf \\
\hline 63 & -48.362 & -21.593 & Matão & 605.00 & 456.00 & 354.00 & 302.00 & 354.00 & 430.00 & & & 76.00 & $>24.00$ & & $>24.00$ & $>100.00$ & BOT/PIRf \\
\hline 64 & -48.379 & -21.583 & Matão & 580.00 & 531.00 & 328.00 & 266.00 & 328.00 & 482.00 & & & 154.00 & $>49.00$ & & $>49.00$ & $>203.00$ & BOT/PIRf \\
\hline 65 & -48.371 & -21.597 & Matão & 540.00 & 442.00 & 246.00 & 234.00 & 246.00 & 414.00 & & & 168.00 & $>27.00$ & & $>27.00$ & $>195.00$ & BOT/PIRf \\
\hline 66 & -48.520 & -21.271 & Monte Alto & 750.00 & 707.00 & 643.00 & 413.00 & 643.00 & & & & $>64.00$ & & & & $>64.00$ & BOT \\
\hline 67 & -48.570 & -21.778 & Nova Europa & 530.00 & 305.00 & 213.00 & 185.00 & 213.00 & & & & $>92.00$ & & & & $>92.00$ & BOT \\
\hline 68 & -47.880 & -20.717 & Orlândia & 660.00 & 448.00 & 200.00 & 200.00 & 200.00 & & 340.00 & & 140.00 & 0.00 & $>108.00$ & $>108.00$ & $>248.00$ & BOT/PIRe \\
\hline 69 & -48.777 & -22.346 & Pederneiras & 480.00 & 325.00 & 125.00 & 125.00 & 125.00 & & 274.00 & & 149.00 & 0.00 & $>48.00$ & $>48.00$ & $>197.00$ & BOT/PIRe \\
\hline 70 & -47.924 & -22.837 & Piracicaba & 515.00 & 60.00 & 0.00 & 0.00 & 0.00 & & 16.00 & 44.00 & 16.00 & 0.00 & 28.00 & 28.00 & 44.00 & $\mathrm{BOT} / \mathrm{PIRe}$ \\
\hline 71 & -49.387 & -23.186 & Piraju & 540.00 & 322.00 & 258.00 & 258.00 & 258.00 & & & & $>64.00$ & & & & $>64.00$ & BOT \\
\hline 72 & -48.668 & -21.090 & Pirangi & 530.00 & 560.00 & 362.00 & 279.00 & 362.00 & & 496.00 & & 128.00 & 0.00 & $>64.00$ & $>64.00$ & $>192.00$ & BOT/PIRe \\
\hline 73 & -48.219 & -21.014 & Pitangueiras & 510.00 & 692.00 & 492.00 & 492.00 & 492.00 & & 592.00 & & 100.00 & 0.00 & $>100.00$ & $>100.00$ & $>200.00$ & BOT/PIRe \\
\hline 74 & -48.095 & -21.358 & Pradópolis & 538.00 & 357.00 & 50.00 & 50.00 & 50.00 & & & & $>190.00$ & & & & $>190.00$ & BOT \\
\hline 75 & -51.414 & -22.122 & $\begin{array}{l}\text { Presidente } \\
\text { Prudente }\end{array}$ & 407.00 & 1795.00 & 1410.00 & 1192.00 & 1410.00 & 1548.00 & 1566.00 & 1784.00 & 138.00 & 18.00 & 218.00 & 236.00 & 374.00 & BOT/PIRf/PIRe \\
\hline 76 & -51.402 & -22.119 & $\begin{array}{c}\text { Presidente } \\
\text { Prudente }\end{array}$ & 420.00 & 1795.00 & 1608.00 & 1376.00 & 1608.00 & 1713.00 & 1760.00 & & 105.00 & 47.00 & $>35.00$ & $>82.00$ & $>187.00$ & BOT/PIRf/PIRe \\
\hline 77 & -48.183 & -22.067 & Ribeirão Bonito & 640.00 & 66.00 & 0.00 & 0.00 & & & 0.00 & & 0.00 & 0.00 & $>65.00$ & $>65.00$ & $>65.00$ & $\mathrm{PIRe}$ \\
\hline 78 & -48.183 & -22.064 & Ribeirão Bonito & 573.00 & 114.00 & 0.00 & 0.00 & 0.00 & 19.00 & & & 19.00 & $>90.00$ & & $>90.00$ & $>109.00$ & BOT/PIRf \\
\hline 79 & -47.843 & -21.195 & Ribeirão Preto & 590.00 & 384.00 & 164.00 & 164.00 & 164.00 & 266.00 & 306.00 & & 102.00 & 40.00 & $>78.00$ & $>118.00$ & $>220.00$ & BOT/PIRf/PIRe \\
\hline 80 & -48.082 & -21.589 & Rincão & 580.00 & 205.00 & 104.00 & 104.00 & 104.00 & & & & $>101.00$ & & & & $>101.00$ & BOT \\
\hline 81 & -47.909 & -21.627 & Rincão & 510.00 & 120.00 & 0.00 & 0.00 & 0.00 & 6.00 & 92.00 & & 6.00 & 86.00 & $>58.00$ & $>144.00$ & $>150.00$ & BOT/PIRf \\
\hline 82 & -48.074 & -21.702 & Santa Lúcia & 635.00 & 250.00 & 142.00 & 142.00 & 142.00 & & 234.00 & & 92.00 & 0.00 & $>16.00$ & $>16.00$ & $>108.00$ & BOT/PIRe \\
\hline 83 & -47.368 & -21.526 & $\begin{array}{c}\text { Santa Rosa do } \\
\text { Viterbo }\end{array}$ & 780.00 & 109.00 & 0.00 & 0.00 & & & 0.00 & & 0.00 & 0.00 & $>109.0$ & $>109.00$ & $>109.00$ & $\mathrm{PIRe}$ \\
\hline 84 & -47.950 & -21.968 & São Carlos & 850.00 & 260.00 & 119.00 & 119.00 & 119.00 & & 241.00 & & 122.00 & 0.00 & $>19.00$ & $>19.00$ & $>141.00$ & BOT/PIRe \\
\hline 85 & -47.865 & -21.999 & São Carlos & 890.00 & 386.00 & 262.00 & 236.00 & 262.00 & & & & $>124.00$ & & & & $>124.00$ & BOT \\
\hline 86 & -47.889 & -22.047 & São Carlos & 845.00 & 282.00 & 86.00 & 26.00 & 86.00 & 200.00 & & & 114.00 & $>82.00$ & & $>82.00$ & $>196.00$ & BOT/PIRf \\
\hline 87 & -47.900 & -21.977 & São Carlos & 870.00 & 235.00 & 162.00 & 162.00 & 162.00 & & & & $>71.00$ & & & & $>71.00$ & BOT \\
\hline
\end{tabular}




\begin{tabular}{|c|c|c|c|c|c|c|c|c|c|c|c|c|c|c|c|c|c|}
\hline Ref. & LONG & LAT & Município & cota-BP & $\begin{array}{l}\text { prof- } \\
\text { final }\end{array}$ & $\begin{array}{l}\text { esp- } \\
\text { conf. }\end{array}$ & esp-SG & $\begin{array}{l}\text { prof-tp- } \\
\text { BOT }\end{array}$ & $\begin{array}{l}\text { prof-tp- } \\
\text { PirSup }\end{array}$ & $\begin{array}{l}\text { prof-tp- } \\
\text { PIR }\end{array}$ & \begin{tabular}{|l} 
prof-tp- \\
PD
\end{tabular} & $\begin{array}{l}\text { esp- } \\
\text { BOT }\end{array}$ & $\begin{array}{c}\text { esp- } \\
\text { PirSup }\end{array}$ & esp-PIR & $\begin{array}{l}\text { esp- } \\
\text { PIRt }\end{array}$ & $\begin{array}{l}\text { esp- } \\
\text { Gua }\end{array}$ & Aquífero \\
\hline 88 & -47.865 & -20.593 & $\begin{array}{l}\text { São Joaquim da } \\
\text { Barra }\end{array}$ & 690.00 & 588.00 & 362.00 & 362.00 & 362.00 & & & & $>179.00$ & & & & $>179.00$ & BOT \\
\hline 89 & -49.373 & -20.807 & $\begin{array}{c}\text { São José do Rio } \\
\text { Preto }\end{array}$ & 467.00 & 1100.00 & 790.00 & 682.00 & 790.00 & 860.00 & 886.00 & & 70.00 & 26.00 & $>214.00$ & $>240.00$ & 70.00 & BOT/PIRf/PIRe \\
\hline 90 & -49.375 & -20.789 & $\begin{array}{c}\text { São José do Rio } \\
\text { Preto }\end{array}$ & 490.00 & 1122.00 & 834.00 & 712.00 & 834.00 & 944.00 & 1024.00 & & 110.00 & 80.00 & $>98.00$ & $>178.00$ & 110.00 & BOT/PIRf/PIRe \\
\hline 91 & -49.373 & -20.831 & $\begin{array}{c}\text { São José do Rio } \\
\text { Preto }\end{array}$ & 545.00 & 1152.00 & 825.00 & 626.00 & 825.00 & 1007.00 & 1066.00 & & 182.00 & 59.00 & $>86.00$ & $>145.00$ & 182.00 & BOT/PIRf/PIRe \\
\hline 92 & -49.404 & -20.837 & $\begin{array}{c}\text { São José do Rio } \\
\text { Preto }\end{array}$ & 510.00 & 1024.00 & 768.00 & 611.00 & 768.00 & 940.00 & 997.00 & & 172.00 & 57.00 & $>27.00$ & $>84.00$ & 172.00 & BOT/PIRf/PIRe \\
\hline 93 & -47.979 & -21.137 & Sertãozinho & 560.00 & 408.00 & 180.00 & 180.00 & 180.00 & & 270.00 & & 90.00 & 0.00 & $>132.00$ & $>132.00$ & 90.00 & BOT/PIRe \\
\hline 94 & -47.960 & -21.120 & Sertãozinho & 590.00 & 323.00 & 120.00 & 120.00 & 120.00 & & 206.00 & & 86.00 & 0.00 & $>117.00$ & $>117.00$ & 86.00 & BOT/PIRe \\
\hline 95 & -48.494 & -21.397 & Taquaritinga & 540.00 & 565.00 & 305.00 & 244.00 & 305.00 & 450.00 & 550.00 & & 145.00 & 56.00 & $>15.00$ & $>71.00$ & 145.00 & BOT/PIRf/PIRe \\
\hline 96 & -49.610 & -23.211 & Timburi & 736.00 & 182.00 & 84.00 & 84.00 & 84.00 & & & & $>96.00$ & & & & $>96.00$ & BOT \\
\hline 97 & -50.505 & -21.918 & Tupã & 432.00 & 1479.00 & 1131.00 & 985.00 & 1131.00 & & & & 165.00 & & & $>139.00$ & $>304.00$ & BOT/PIR \\
\hline 98 & -49.203 & -20.429 & Votuporanga & 520.00 & 1352.00 & 1196.00 & 1053.00 & 1196.00 & 1296.00 & 1344.00 & 1350.00 & 100.00 & 48.00 & $>6.00$ & $>54.00$ & 100.00 & BOT/PIRf/PIRe \\
\hline 99 & -48.181 & -22.782 & Anhembi & 502.00 & 1659.00 & 0.00 & 0.00 & & & & & 0.00 & 0.00 & & & & $\mathrm{PIRe}$ \\
\hline 100 & -50.365 & -21.130 & Araçatuba & 371.00 & 3605.00 & 928.00 & 868.00 & 928.00 & 1143.00 & 1190.00 & 1405.00 & 175.00 & 47.00 & 215.00 & 262.00 & 175.00 & BOT/PIRf/PIRe \\
\hline 101 & -50.793 & -21.654 & Lagoa Azul & 420.00 & 4416.00 & 1245.00 & 1092.00 & 1245.00 & & 1345.00 & 1561.00 & 100.00 & & & 216.00 & 316.00 & BOT/PIR \\
\hline 102 & -49.676 & -21.670 & Lins & 417.00 & 3459.00 & 606.00 & 496.00 & 606.00 & 841.00 & 935.00 & 1186.00 & 218.00 & 78.00 & 93.00 & 171.00 & 218.00 & BOT/PIRf/PIRe \\
\hline 103 & -48.928 & -20.688 & Olímpia & 499.00 & 2568.00 & 864.00 & 802.00 & 864.00 & 965.00 & 1016.00 & 1273.00 & 101.00 & 51.00 & 219.00 & 270.00 & 101.00 & BOT/PIRf/PIRe \\
\hline 104 & -50.575 & -22.417 & $\begin{array}{c}\text { Paraguaçu } \\
\text { Paulista }\end{array}$ & 478.00 & 3663.00 & 974.00 & 910.00 & 974.00 & & 1175.00 & 1250.00 & 201.00 & & & 75.00 & 201.00 & BOT/PIR \\
\hline 105 & -52.100 & -21.753 & $\begin{array}{l}\text { Presidente } \\
\text { Epitácio }\end{array}$ & 184.00 & 3950.00 & 1623.00 & 1529.00 & 1623.00 & & & 1860.00 & & & & & 237.00 & BOT/PIR \\
\hline 106 & -51.750 & -20.879 & Três Lagoas & 316.00 & 4582.00 & 823.00 & & 823.00 & & & 1255.00 & & & & & 432.00 & BOT/PIR \\
\hline 107 & -49.152 & -22.467 & Piratininga & 570.00 & 2103.00 & & 0.00 & & & & & 0.00 & 0.00 & 0.00 & 0.00 & 0.00 & - \\
\hline 108 & -47.254 & -21.023 & Altinópolis & 836.00 & 0.00 & 0.00 & 0.00 & & & & & 0.00 & 0.00 & $>20.00$ & $>20.00$ & $>20.00$ & $\mathrm{PIRe}$ \\
\hline 109 & -47.203 & -21.028 & Altinópolis & 797.00 & 0.00 & 0.00 & 0.00 & & & & & $>20.00$ & & & & $>20.00$ & BOT \\
\hline 110 & -47.640 & -22.127 & Analândia & 712.00 & 0.00 & 0.00 & 0.00 & & & & & 0.00 & $>5.00$ & & $>20.00$ & $>20.00$ & PIRf/PIRe \\
\hline 111 & -48.259 & -23.369 & Angatuba & 702.00 & 0.00 & 0.00 & 0.00 & & & & & 0.00 & 0.00 & $>20.00$ & $>20.00$ & $>20.00$ & PIRe \\
\hline 112 & -48.020 & -22.760 & Anhembi & 525.00 & 0.00 & 0.00 & 0.00 & & & & & 0.00 & 0.00 & $>20.00$ & $>20.00$ & $>20.00$ & $\mathrm{PIRe}$ \\
\hline 113 & -48.744 & -21.828 & Araraquara & 413.00 & 0.00 & 0.00 & 0.00 & & & & & $>20.00$ & & & & $>20.00$ & BOT \\
\hline 114 & -48.351 & -22.247 & Brotas & 669.00 & 0.00 & 0.00 & 0.00 & & & & & $>20.00$ & & & & $>20.00$ & BOT \\
\hline 115 & -48.233 & -23.193 & Conchas & 553.00 & 0.00 & 0.00 & 0.00 & & & & & 0.00 & 0.00 & $>20.00$ & $>20.00$ & $>20.00$ & PIRe \\
\hline
\end{tabular}




\begin{tabular}{|c|c|c|c|c|c|c|c|c|c|c|c|c|c|c|c|c|c|}
\hline Ref. & LONG & LAT & Município & cota-BP & $\begin{array}{l}\text { prof- } \\
\text { final }\end{array}$ & $\begin{array}{l}\text { esp- } \\
\text { conf. }\end{array}$ & esp-SG & $\begin{array}{c}\text { prof-tp- } \\
\text { BOT }\end{array}$ & $\begin{array}{l}\text { prof-tp- } \\
\text { PirSup } \\
\end{array}$ & $\begin{array}{c}\text { prof-tp- } \\
\text { PIR } \\
\end{array}$ & $\begin{array}{c}\text { prof-tp- } \\
\text { PD }\end{array}$ & $\begin{array}{l}\text { esp- } \\
\text { BOT }\end{array}$ & $\begin{array}{c}\text { esp- } \\
\text { PirSup }\end{array}$ & esp-PIR & $\begin{array}{l}\text { esp- } \\
\text { PIRt }\end{array}$ & $\begin{array}{l}\text { esp- } \\
\text { Gua }\end{array}$ & Aquífero \\
\hline 116 & -48.233 & -23.193 & Conchas & 553.00 & 0.00 & 0.00 & 0.00 & & & & & 0.00 & 0.00 & $>20.00$ & $>20.00$ & $>20.00$ & PIRe \\
\hline 117 & -47.618 & -22.006 & Corumbataí & 810.00 & 0.00 & 0.00 & 0.00 & & & & & 0.00 & $>5.00$ & $>20.00$ & $>20.00$ & $>20.00$ & PIRf/PIRe \\
\hline 118 & -47.689 & -22.110 & Corumbataí & 886.00 & 0.00 & 0.00 & 0.00 & & & & & 0.00 & $>5.00$ & $>20.00$ & $>20.00$ & $>20.00$ & PIRf/PIRe \\
\hline 119 & -48.203 & -23.345 & Guareí & 703.00 & 0.00 & 0.00 & 0.00 & & & & & 0.00 & 0.00 & $>20.00$ & $>20.00$ & $>20.00$ & PIRe \\
\hline 120 & -47.557 & -21.472 & São Simao & 623.00 & 0.00 & 0.00 & 0.00 & & & & & $>20.00$ & & & & $>20.00$ & BOT \\
\hline 121 & -51.157 & -23.934 & Ivaiporã & 1100.00 & 0.00 & 0.00 & 0.00 & & & & & 0.00 & $>5.00$ & $>20.00$ & $>20.00$ & $>20.00$ & PIRf/PIRe \\
\hline 122 & -49.455 & -23.272 & Piraju & 738.00 & 0.00 & 0.00 & 0.00 & & & & & $>20.00$ & & & & $>20.00$ & BOT \\
\hline 123 & -48.201 & -22.506 & $\begin{array}{c}\text { Santa Maria da } \\
\text { Serra }\end{array}$ & 665.00 & 0.00 & 0.00 & 0.00 & & & & & $>20.00$ & & & & $>20.00$ & BOT \\
\hline 124 & -48.052 & -22.559 & $\begin{array}{c}\text { Santa Maria da } \\
\text { Serra }\end{array}$ & 532.00 & 0.00 & 0.00 & 0.00 & & & & & $>20.00$ & & & & $>20.00$ & BOT \\
\hline 125 & -47.801 & -22.537 & São Pedro & 546.00 & 0.00 & 0.00 & 0.00 & & & & & 0.00 & 0.00 & $>20.00$ & $>20.00$ & $>20.00$ & PIRe \\
\hline 126 & -47.821 & -22.541 & São Pedro & 515.00 & 0.00 & 0.00 & 0.00 & & & & & 0.00 & 0.00 & $>20.00$ & $>20.00$ & $>20.00$ & $\mathrm{PIRe}$ \\
\hline
\end{tabular}

\section{Abreviações:}

Coordenadas: LONG - longitude, em graus decimais; LAT - latitude, em graus decimais.

Cota-BP - cota da boca do poço, em metros.

prof-final - profundidade final do poço, em metros.

esp-conf. - espessura de confinamento do aqüífero, em metros.

esp-SG - espessura da Formação Serra Geral, em metros.

prof-tp-Bot - profundidade do topo da Formação Botucatu, em metros.

prof-tp-PirSup - profundidade do topo da Formação Pirambóia Superior (flúvio-eólica), em metros.

prof-tp-Pir - profundidade do topo da Formação Pirambóia (eólica), em metros.

prof-tp-PD - profundidade do topo do Grupo Passa Dois, em metros.

esp-BOT - espessura da Formação Botucatu, em metros.

esp-PirSup - espessura da Formação Pirambóia Superior, em metros.

esp-PIR - espessura da Formação Pirambóia, em metros.

esp-PIRt - espessura da Formação Pirambóia (total), em metros.

esp-Gua - espessura do Aqüífero Guarani, em metros.

Aquífero - aqüíferos atravessados: BOT - Botucatu, PIRf - Pirambóia flúvio-eólico, PIRe - Pirambóia eólico.

Fonte de dados: DAEE (Superintendência de Araraquara), CPRM, SABESP, SAAEJ (Serviço de Água e Esgoto de Jaboticabal), DAEM (Departamento de Água e Esgoto de Marília), ANP/BDEP, Ramos \& Formoso (1970). 
Tabela 2 - Dados petrográficos (1).

\begin{tabular}{|c|c|c|c|c|c|c|c|c|c|c|c|c|c|c|}
\hline Município & Cota-BP & Unidade & $\begin{array}{l}\text { Petro- } \\
\text { fácies }\end{array}$ & Fácies & Profund. & Cota & $\begin{array}{l}\text { gran } \\
\text { med }\end{array}$ & $\begin{array}{l}\text { gran } \\
\text { mod }\end{array}$ & moda1 & moda2 & seleção & DP1 & DP2 & $\begin{array}{l}\text { arred } \\
\text { md }\end{array}$ \\
\hline Agudos & 620.00 & BOT & QA1p & duna & 178.00 & 442.00 & 204.0 & 210.0 & & & 0.57 & & & 0.6 \\
\hline Aracatuba & 410.00 & PIR-SUP & $F A 2 c(p)$ & $\begin{array}{l}\text { flúvio- } \\
\text { eólica }\end{array}$ & 1158.00 & -748.00 & 160.0 & 163.0 & & & 0.39 & & & 0.5 \\
\hline Araçatuba & 410.00 & PIR-SUP & QA2p & $\begin{array}{l}\text { flúvio- } \\
\text { eólica }\end{array}$ & 1158.00 & -748.00 & 100.0 & 105.0 & & & 0.74 & & & 0.4 \\
\hline Araraquara & 640.00 & PIR-SUP & QA1(p) & $\begin{array}{l}\text { flúvio- } \\
\text { eólica }\end{array}$ & 296.00 & 344.00 & 607.0 & 771.0 & 115.0 & 771.0 & 1.00 & 0.41 & 0.58 & 0.5 \\
\hline Araraquara & 640.00 & BOT & QA1(p) & duna & 156.00 & 484.00 & 217.0 & 230.0 & & & 0.47 & & & 0.5 \\
\hline Araraquara & 600.00 & BOT & Qa1(p) & duna & 202.00 & 398.00 & 266.0 & 273.0 & & & 0.58 & & & 0.5 \\
\hline Araraquara & 600.00 & PIR & QA1(p,c) & $\begin{array}{l}\text { flúvio- } \\
\text { eólica }\end{array}$ & 358.00 & 242.00 & 276.0 & 230.0 & & & 0.64 & & & 0.5 \\
\hline Barretos & 560.00 & PIR & QA1p & eólica & 934.00 & -359.00 & 188.0 & 137.0 & 137.0 & 410.0 & 0.79 & 0.50 & 0.43 & 0.5 \\
\hline Barretos & 560.00 & PIR & FA1c & eólica & 934.00 & -359.00 & 185.0 & 137.0 & 108.0 & 231.0 & 0.65 & 0.26 & 0.49 & 0.5 \\
\hline Barretos & 575.00 & BOT & QA1p & eólica & 852.00 & -277.00 & 238.0 & 221.0 & 193.0 & 385.0 & 0.61 & 0.39 & 0.32 & 0.5 \\
\hline Barretos & 575.00 & BOT & QA1p & eólica & 890.00 & -315.00 & 218.0 & 202.0 & 134.0 & 398.0 & 0.77 & 0.56 & 0.30 & 0.5 \\
\hline Barretos & 575.00 & PIR-SUP & QA2C & $\begin{array}{l}\text { flúvio- } \\
\text { eólica }\end{array}$ & 910.00 & -335.00 & 432.0 & 423.0 & 139.0 & 423.0 & 0.38 & 0.40 & 0.41 & 0.5 \\
\hline Barretos & 575.00 & PIR-SUP & QA2C & $\begin{array}{l}\text { flúvio- } \\
\text { eólica }\end{array}$ & 928.00 & -353.00 & 324.0 & 335.0 & 212.0 & 355.0 & 0.52 & 0.41 & 0.35 & 0.5 \\
\hline Barretos & 575.00 & PIR & QA1p & eólica & 952.00 & -377.00 & 233.0 & 273.0 & & & 0.53 & & & 0.5 \\
\hline Barretos & 575.00 & PIR & QA1c & eólica & 952.00 & -377.00 & 171.0 & 115.0 & 115.0 & 385.0 & 0.77 & 0.48 & 0.49 & 0.5 \\
\hline Barretos & 575.00 & PIR & FA1i & eólica & 948.00 & -373.00 & 151.0 & 163.0 & & & 0.45 & & & 0.5 \\
\hline Barretos & 575.00 & PIR & FA1p & eólica & 968.00 & -393.00 & & & & & & & & 0.5 \\
\hline Barretos & 575.00 & PIR & QA1c & eólica & 968.00 & -393.00 & 170.0 & 163.0 & & & 0.31 & & & 0.5 \\
\hline Barrinha & 520.00 & PIR-SUP & QA2c & $\begin{array}{l}\text { flúvio- } \\
\text { eólica }\end{array}$ & 394.00 & 126.00 & 234.0 & 210.0 & 200.0 & 402.0 & 0.60 & 0.42 & 0.29 & 0.5 \\
\hline Barrinha & 520.00 & PIR-SUP & QA2C & fluvial & 394.00 & 126.00 & 281.0 & 300.0 & & & 0.86 & & & 0.4 \\
\hline Batatais & 700.00 & BOT & FA1p & duna & 124.00 & 579.50 & 145.0 & 137.0 & & & 0.53 & & & 0.5 \\
\hline Batatais & 700.00 & PIR-SUP & QA2p & $\begin{array}{l}\text { flúvio- } \\
\text { eólica }\end{array}$ & 168.00 & 535.50 & 210.0 & 193.0 & & & 0.60 & & & 0.4 \\
\hline Batatais & 700.00 & PIR & QA1p & eólica & 254.00 & 449.50 & 182.0 & 197.0 & & & 0.49 & & & 0.5 \\
\hline Batatais & 840.00 & BOT & QA2s & eólica & 330.00 & 510.00 & 219.0 & 163.0 & & & 0.50 & & & 0.5 \\
\hline Batatais & 840.00 & PIR & QA2c(p) & eólica & 496.00 & 344.00 & 200.0 & 193.0 & & & 0.67 & & & 0.5 \\
\hline
\end{tabular}




\begin{tabular}{|c|c|c|c|c|c|c|c|c|c|c|c|c|c|c|}
\hline Município & Cota-BP & Unidade & $\begin{array}{l}\text { Petro- } \\
\text { fácies }\end{array}$ & Fácies & Profund. & Cota & $\begin{array}{l}\text { gran } \\
\text { med }\end{array}$ & \begin{tabular}{|l|} 
gran \\
mod
\end{tabular} & moda1 & moda2 & seleção & DP1 & DP2 & \begin{tabular}{|l} 
arred \\
md
\end{tabular} \\
\hline Bauru & 510.00 & BOT & QA1C & duna & 78.00 & 432.00 & 167.0 & 137.0 & & & 0.42 & & & 0.5 \\
\hline Bauru & 533.50 & PIR-SUP & QA2(p) & $\begin{array}{l}\text { flúvio- } \\
\text { eólica }\end{array}$ & 290.00 & 243.50 & & & 105.0 & 300.0 & 0.60 & 0.40 & 0.40 & 0.5 \\
\hline Catanduva & 500.00 & BOT & QA1 & duna & 476.00 & 24.00 & 247.0 & & 136.0 & 273.0 & 0.68 & 0.33 & 0.36 & 0.5 \\
\hline Catanduva & 500.00 & PIR-SUP & QA1 & eólica & 668.00 & -168.00 & 360.0 & 460.0 & & & 0.56 & & & 0.5 \\
\hline Dois Córregos & 722.00 & PIR & QA1p & eólica & 552.00 & 170.00 & 198.0 & 149.0 & & & 0.69 & & & 0.4 \\
\hline Fernandópolis & 436.00 & PIR & FA1p & eólica & 1598.00 & -1162.00 & 143.0 & 124.0 & & & 0.52 & & & 0.4 \\
\hline Fernandópolis & 436.00 & PIR & FA2p & eólica & 1598.00 & -1162.00 & 205.0 & 193.0 & & & 0.55 & & & 0.4 \\
\hline Ibaté & 840.00 & BOT & QA1(p) & duna & 234.00 & 606.00 & 209.0 & 193.0 & & & 0.49 & & & 0.5 \\
\hline Macatuba & 500.00 & BOT & QA1p & duna & 156.00 & 344.00 & 187.0 & 163.0 & & & 0.53 & & & 0.5 \\
\hline Matão & 580.00 & BOT & QA2C & duna & 446.00 & 134.00 & 196.0 & 149.0 & & & 0.53 & & & 0.5 \\
\hline Matão & 580.00 & BOT & QA1c & duna & 492.00 & 88.00 & 232.0 & 230.0 & & & 0.43 & & & 0.5 \\
\hline Matão & 580.00 & PIR-SUP & QA1f & $\begin{array}{l}\text { flúvio- } \\
\text { eólica }\end{array}$ & 508.00 & 72.00 & 362.0 & & 114.0 & 687.0 & 1.36 & 0.64 & 0.38 & 0.5 \\
\hline Matão & 580.00 & PIR-SUP & QA2f & $\begin{array}{l}\text { flúvio- } \\
\text { eólica }\end{array}$ & 508.00 & 72.00 & 523.0 & 545.0 & & & 0.35 & & & 0.7 \\
\hline Matão & 540.00 & PIR-SUP & QA2C & $\begin{array}{l}\text { flúvio- } \\
\text { eólica }\end{array}$ & 428.00 & 112.00 & 264.0 & 230.0 & & & 0.55 & & & 0.5 \\
\hline Matão & 540.00 & PIR-SUP & QA2f & $\begin{array}{l}\text { flúvio- } \\
\text { eólica }\end{array}$ & 428.00 & 112.00 & 375.0 & 385.0 & & & 0.52 & & & 0.5 \\
\hline Orlândia & 660.00 & PIR & FA1c & eólica & 380.00 & 280.00 & 182.0 & 193.0 & & & 0.54 & & & 0.5 \\
\hline Orlândia & 660.00 & PIR & FA1p & eólica & 450.00 & 210.00 & 179.0 & 193.0 & & & 0.47 & & & 0.5 \\
\hline Pitangueiras & 510.00 & PIR & QA1p & eólica & 682.00 & -172.00 & 180.0 & 163.0 & & & 0.55 & & & 0.4 \\
\hline $\begin{array}{l}\text { Presidente } \\
\text { Prudente }\end{array}$ & 420.00 & PIR-SUP & QA2c & $\begin{array}{l}\text { flúvio- } \\
\text { eólica }\end{array}$ & 1698.00 & -1278.00 & 320.0 & 163.0 & 163.0 & 460.0 & 0.71 & 0.35 & 0.35 & 0.5 \\
\hline $\begin{array}{l}\text { Presidente } \\
\text { Prudente }\end{array}$ & 420.00 & PIR-SUP & QA2p & $\begin{array}{l}\text { flúvio- } \\
\text { eólica }\end{array}$ & 1702.00 & -1282.00 & 110.0 & 137.0 & 136.0 & 325.0 & 0.70 & 0.41 & 0.36 & 0.3 \\
\hline Santa Lúcia & 635.00 & BOT & QA1p & duna & 248.00 & 387.00 & 182.0 & 163.0 & 163.0 & 460.0 & 0.74 & 0.51 & 0.27 & 0.4 \\
\hline $\begin{array}{c}\text { Santa Rosa } \\
\text { Viterbo }\end{array}$ & 780.00 & PIR & FA1p & eólica & 100.00 & 680.00 & 274.0 & 273.0 & & & 0.43 & & & 0.6 \\
\hline São Carlos & 850.00 & BOT & QA1p & duna & 234.00 & 616.00 & 208.0 & 193.0 & 115.0 & 420.0 & 0.69 & 0.47 & 0.42 & 0.5 \\
\hline São Carlos & 845.00 & BOT & QA1p & duna & 118.00 & 727.00 & 190.0 & 193.0 & & & 0.40 & & & 0.5 \\
\hline $\begin{array}{c}\text { São Jose Rio } \\
\text { Preto }\end{array}$ & 545.00 & BOT & QA1(p) & duna & 848.00 & -303.00 & 314.0 & 300.0 & & & 0.43 & & & 0.5 \\
\hline
\end{tabular}




\begin{tabular}{|c|c|c|c|c|c|c|c|c|c|c|c|c|c|c|}
\hline Município & Cota-BP & Unidade & $\begin{array}{l}\text { Petro- } \\
\text { fácies }\end{array}$ & Fácies & Profund. & Cota & $\begin{array}{l}\text { gran } \\
\text { med }\end{array}$ & $\begin{array}{l}\text { gran } \\
\text { mod }\end{array}$ & moda1 & moda2 & seleção & DP1 & DP2 & $\begin{array}{l}\text { arred } \\
\text { md }\end{array}$ \\
\hline $\begin{array}{c}\text { São José Rio } \\
\text { Preto }\end{array}$ & 545.00 & PIR-SUP & $\mathrm{QA1}(\mathrm{c}, \mathrm{p})$ & $\begin{array}{l}\text { flúvio- } \\
\text { eólica }\end{array}$ & 1024.00 & -479.00 & 380.0 & 385.0 & & & 0.74 & & & 0.5 \\
\hline $\begin{array}{c}\text { São José Rio } \\
\text { Preto }\end{array}$ & 545.00 & PIR & FA1(c,p) & eólica & 1136.00 & -591.00 & 113.0 & 105.0 & & & 0.45 & & & 0.5 \\
\hline Sertãozinho & 560.00 & PIR & QA1p & eólica & 376.00 & 184.00 & 108.0 & 225.0 & & & 0.49 & & & 0.5 \\
\hline Sertãozinho & 590.00 & PIR-SUP & QA2C & $\begin{array}{l}\text { flúvio- } \\
\text { eólica }\end{array}$ & 304.00 & 286.00 & 240.0 & 210.0 & & & 0.79 & & & 0.6 \\
\hline Sertãozinho & 590.00 & PIR-SUP & QA1p & $\begin{array}{l}\text { flúvio- } \\
\text { eólica }\end{array}$ & 316.00 & 274.00 & 168.0 & 149.0 & & & 1.03 & & & 0.4 \\
\hline Votuporanga & 520.00 & BOT & QA1(p) & duna & 1198.00 & -678.00 & 245.0 & 230.0 & & & 0.57 & & & 0.5 \\
\hline Votuporanga & 520.00 & PIR-SUP & $\mathrm{QA} 2(\mathrm{p}, \mathrm{c})$ & $\begin{array}{l}\text { flúvio- } \\
\text { eólica }\end{array}$ & 1316.00 & -796.00 & 422.0 & 460.0 & & & 0.50 & & & 0.4 \\
\hline Votuporanga & 520.00 & PIR-SUP & QA2(p,c) & fluvial & 1340.00 & -820.00 & 459.0 & 385.0 & & & 0.81 & & & 0.35 \\
\hline Araçatuba & 363.00 & BOT & QA1p & duna & 1116.00 & -745.00 & 197.0 & & 135.0 & 437.0 & 0.82 & 0.45 & 0.38 & 0.5 \\
\hline Araçatuba & 363.00 & PIR-SUP & QA2 & $\begin{array}{l}\text { flúvio- } \\
\text { eólica }\end{array}$ & 1173.00 & -802.00 & 1050.0 & 917.0 & & & 0.40 & & & 0.3 \\
\hline Araçatuba & 363.00 & PIR & FA1p & eólica & 1338.00 & -967.00 & 260.0 & 193.0 & 187.0 & 399.0 & 0.66 & 0.42 & 0.34 & 0.5 \\
\hline Lagoa Azul & 420.00 & BOT & QA1(p,c) & duna & 1317.00 & -897.00 & 280.0 & & 210.0 & 350.0 & 0.50 & 0.40 & 0.40 & 0.6 \\
\hline Lagoa Azul & 420.00 & PIR-SUP & $\mathrm{QA} 2(\mathrm{p}, \mathrm{c})$ & $\begin{array}{l}\text { flúvio- } \\
\text { eólica }\end{array}$ & 1341.00 & -921.00 & 1114.0 & 1091.0 & & & 0.27 & & & 0.3 \\
\hline Lins & 411.50 & BOT & QA1p & duna & 750.00 & -333.00 & 163.0 & 163.0 & & & 0.54 & & & 0.45 \\
\hline Lins & 411.50 & PIR & FA1p & interduna & 949.00 & -532.00 & 203.0 & 163.0 & 163.0 & 917.0 & 0.79 & 0.53 & 0.48 & 0.4 \\
\hline Olímpia & 495.00 & PIR & FA1i & interduna & 1032.20 & -533.20 & 199.0 & 137.0 & & & 0.79 & & & 0.4 \\
\hline $\begin{array}{l}\text { Presidente } \\
\text { Epitácio }\end{array}$ & 184.00 & BOT & QA1p & duna & 1625.00 & -1441.00 & 184.0 & 149.0 & & & 0.77 & & & 0.5 \\
\hline $\begin{array}{l}\text { Presidente } \\
\text { Epitácio }\end{array}$ & 184.00 & BOT & QA1p & duna & 1732.00 & -1548.00 & 132.0 & 163.0 & & & 0.58 & & & 0.5 \\
\hline $\begin{array}{l}\text { Presidente } \\
\text { Epitácio }\end{array}$ & 184.00 & PIR-SUP & FA2c & $\begin{array}{l}\text { flúvio- } \\
\text { eólica }\end{array}$ & 1732.00 & -1548.00 & 204.0 & 230.0 & 137.0 & 230.0 & 0.62 & 0.38 & 0.33 & 0.4 \\
\hline $\begin{array}{l}\text { Presidente } \\
\text { Epitácio }\end{array}$ & 184.00 & PIR & FA2 $i$ & eólica & 1813.00 & -1629.00 & 188.0 & 137.0 & 137.0 & 230.0 & 0.55 & & & 0.4 \\
\hline Brotas & 669.00 & BOT & FA1p & duna & 0.00 & 669.00 & 195.0 & 230.0 & 97.0 & 230.0 & 0.52 & 0.29 & 0.38 & 0.6 \\
\hline Analândia & 712.00 & PIR & QA1p & $\begin{array}{c}\text { duna/inte } \\
\text { rd }\end{array}$ & 0.00 & 712.00 & 175.0 & 163.0 & & & 0.44 & & & 0.5 \\
\hline Corumbataí & 810.00 & PIR-SUP & QA2p & fluvial & 0.00 & 810.00 & 625.0 & 425.0 & & & 1.04 & & & 0.47 \\
\hline
\end{tabular}




\begin{tabular}{|c|c|c|c|c|c|c|c|c|c|c|c|c|c|c|}
\hline Município & Cota-BP & Unidade & $\begin{array}{l}\text { Petro- } \\
\text { fácies }\end{array}$ & Fácies & Profund. & Cota & \begin{tabular}{|l|}
$\begin{array}{l}\text { gran } \\
\text { med }\end{array}$ \\
\end{tabular} & \begin{tabular}{|l|} 
gran \\
mod
\end{tabular} & moda1 & moda2 & seleção & DP1 & DP2 & $\begin{array}{l}\text { arred } \\
\text { md }\end{array}$ \\
\hline Araraquara & 413.00 & BOT & QA1s & duna & 0.00 & 413.00 & 244.0 & 273.0 & & & 0.47 & & & 0.7 \\
\hline Angatuba & 702.00 & PIR & QAb & duna & 0.00 & 702.00 & 188.0 & 193.0 & & & 0.37 & & & 0.5 \\
\hline Angatuba & 702.00 & PIR & Fab & interduna & 0.00 & 702.00 & 201.0 & 193.0 & & & 0.39 & & & 0.5 \\
\hline Conchas & 553.00 & PIR & $\mathrm{Fab}$ & duna & 0.00 & 553.00 & 140.0 & 115.0 & & & 0.47 & & & 0.4 \\
\hline Conchas & 553.00 & PIR & Fab & interduna & 0.00 & 553.00 & 138.0 & 105.0 & 105.0 & 273.0 & 0.66 & 0.48 & 0.35 & 0.4 \\
\hline Anhembi & 525.00 & PIR & $\mathrm{FAb}$ & duna & 0.00 & 525.00 & 240.0 & 230.0 & & & 0.39 & & & 0.4 \\
\hline Anhembi & 525.00 & PIR & $\mathrm{FAb}$ & interduna & 0.00 & 525.00 & 180.0 & 193.0 & & & 0.45 & & & 0.4 \\
\hline São Pedro & 546.00 & PIR & FA1p & interduna & 0.00 & 546.00 & 152.0 & 137.0 & & & 0.60 & & & 0.4 \\
\hline São Pedro & 546.00 & PIR & FA1p & duna & 0.00 & 546.00 & 190.0 & 105.0 & 137.0 & 385.0 & 0.85 & 0.56 & 0.39 & 0.5 \\
\hline $\begin{array}{c}\text { Santa Maria da } \\
\text { Serra }\end{array}$ & 665.00 & BOT & QA1p & duna & 0.00 & 665.00 & 165.0 & 97.0 & 97.0 & 230.0 & 0.77 & 0.44 & 0.30 & 0.5 \\
\hline $\begin{array}{c}\text { Santa Maria da } \\
\text { Serra }\end{array}$ & 665.00 & BOT & QA1p & interduna & 0.00 & 665.00 & 318.0 & 325.0 & & & 0.70 & & & 0.5 \\
\hline Ivaiporã & 1100.00 & PIR-SUP & QA2p & $\begin{array}{l}\text { flúvio- } \\
\text { eólica }\end{array}$ & 0.00 & 1100.00 & 536.0 & 460.0 & & & 0.56 & & & 0.5 \\
\hline
\end{tabular}

\section{Abreviações:}

Coordenadas: LONG - longitude, em graus decimais; LAT - latitude, em graus decimais.

Cota-BP - cota da boca do poço, em metros.

Unidade: BOT - Formação Botucatu, PIR - Formação Pirambóia. PIR-SUP - Formação Pirambóia Superior (flúvio-eólico).

Profund. - Profundidade amostrada, em metros.

gran_med - granulometria média, em micrômetros.

gran_mod - granulometria modal, em micrômetros.

moda1 - moda granulométrica mais fina (distribuição bimodal), em micrômetros.

moda2 - moda granulométrica mais grossa (distribuição bimodal), em micrômetros.

seleção - segundo escala de Pettijohn et al. (1973).

DP1 - seleção referente à moda 1, segundo classificação de Pettijohn et al. (1973).

DP2 - seleção referente à moda 2, segundo classificação de Pettijohn et al. (1973).

arred_md - arredondamento médio, segundo escala de Powers (1959). 
Tabela 3 - Dados petrográficos (2).

\begin{tabular}{|c|c|c|c|c|c|c|c|c|c|c|c|}
\hline Município & cota-BP & Unidade & $\begin{array}{l}\text { Petro- } \\
\text { fácies }\end{array}$ & Fácies & Profund. & Cota & ARC & MATRIZ & CIM & PORO & IGV \\
\hline Agudos & 620.00 & BOT & QA1p & duna & 178.00 & 442.00 & 53.0 & 0.0 & 6.0 & 41.0 & 47.0 \\
\hline Araçatuba & 410.00 & PIR-SUP & FA2c(p) & flúvio-eólica & 1158.00 & -748.00 & 65.0 & 0.0 & 18.0 & 17.0 & 35.0 \\
\hline Araçatuba & 410.00 & PIR-SUP & QA2p & flúvio-eólica & 1158.00 & -748.00 & 74.0 & 0.0 & 8.0 & 18.0 & 26.0 \\
\hline Barretos & 560.00 & PIR & QA1p & eólica & 934.00 & -359.00 & 73.0 & 0.0 & 6.0 & 21.0 & 27.0 \\
\hline Barretos & 560.00 & PIR & FA1c & eólica & 934.00 & -359.00 & 65.0 & 0.0 & 27.0 & 8.0 & 35.0 \\
\hline Barretos & 575.00 & BOT & QA1p & eólica & 852.00 & -277.00 & 71.6 & 0.0 & 5.6 & 22.8 & 28.4 \\
\hline Barretos & 575.00 & BOT & QA1p & eólica & 890.00 & -315.00 & 70.4 & 0.0 & 7.0 & 22.6 & 29.6 \\
\hline Barretos & 575.00 & PIR-SUP & QA2C & flúvio-eólica & 910.00 & -335.00 & 60.4 & 0.0 & 34.2 & 5.4 & 39.6 \\
\hline Barretos & 575.00 & PIR-SUP & QA2C & flúvio-eólica & 928.00 & -353.00 & 58.8 & 0.0 & 38.0 & 3.2 & 41.2 \\
\hline Barretos & 575.00 & PIR & QA1p & eólica & 952.00 & -377.00 & 67.8 & 0.0 & 7.0 & 25.2 & 32.2 \\
\hline Barretos & 575.00 & PIR & QA1C & eólica & 952.00 & -377.00 & 62.3 & 0.0 & 36.7 & 0.7 & 37.4 \\
\hline Barretos & 575.00 & PIR & FA1i & eólica & 948.00 & -373.00 & 48.0 & 9.0 & 23.0 & 20.0 & 43.0 \\
\hline Barretos & 575.00 & PIR & FA1p & eólica & 968.00 & -393.00 & 63.0 & 0.0 & 6.7 & 30.3 & 37.0 \\
\hline Barretos & 575.00 & PIR & QA1c & eólica & 968.00 & -393.00 & 61.8 & 0.0 & 35.8 & 2.4 & 38.2 \\
\hline Barrinha & 520.00 & PIR-SUP & QA2C & flúvio-eólica & 394.00 & 126.00 & 58.8 & 0.0 & 38.0 & 3.2 & 41.2 \\
\hline Barrinha & 520.00 & PIR-SUP & QA2C & fluvial & 394.00 & 126.00 & 70.5 & 0.0 & 17.5 & 13.0 & 30.5 \\
\hline Batatais & 700.00 & BOT & FA1p & duna & 124.00 & 579.50 & 60.5 & 0.0 & 12.5 & 27.0 & 39.5 \\
\hline Batatais & 700.00 & PIR-SUP & QA2p & flúvio-eólica & 168.00 & 535.50 & 74.4 & 0.0 & 3.8 & 21.8 & 25.6 \\
\hline Batatais & 700.00 & PIR & QA1p & eólica & 254.00 & 449.50 & 61.5 & 0.0 & 8.4 & 30.1 & 38.5 \\
\hline Batatais & 840.00 & BOT & QA2s & eólica & 330.00 & 510.00 & 68.3 & 0.0 & 31.0 & 0.7 & 31.7 \\
\hline Batatais & 840.00 & PIR & QA2c(p) & eólica & 496.00 & 344.00 & 69.2 & 0.0 & 16.8 & 14.0 & 30.8 \\
\hline Bauru & 510.00 & BOT & QA1C & duna & 78.00 & 432.00 & 59.8 & 0.0 & 39.0 & 1.2 & 40.2 \\
\hline Bauru & 533.50 & PIR-SUP & QA2(p) & flúvio-eólica & 290.00 & 243.50 & 81.0 & 0.0 & 12.0 & 7.0 & 19.0 \\
\hline Dois Córregos & 722.00 & PIR & QA1p & eólica & 552.00 & 170.00 & 56.0 & 0.0 & 10.0 & 34.0 & 44.0 \\
\hline Fernandópolis & 436.00 & PIR & FA1p & eólica & 1598.00 & -1162.00 & 64.2 & 0.0 & 8.0 & 27.8 & 35.8 \\
\hline Fernandópolis & 436.00 & PIR & FA2p & eólica & 1598.00 & -1162.00 & 67.4 & 0.0 & 5.6 & 27.0 & 32.6 \\
\hline Macatuba & 500.00 & BOT & QA1p & duna & 156.00 & 344.00 & 46.0 & 0.0 & 18.0 & 36.0 & 54.0 \\
\hline Matão & 580.00 & BOT & QA2c & duna & 446.00 & 134.00 & 70.0 & 0.0 & 30.0 & 0.1 & 30.1 \\
\hline Matão & 580.00 & BOT & QA1C & duna & 492.00 & 88.00 & 63.0 & 0.0 & 26.0 & 11.0 & 37.0 \\
\hline Matão & 580.00 & PIR-SUP & QA2f & flúvio-eólica & 508.00 & 72.00 & 63.8 & 0.0 & 16.0 & 20.2 & 36.2 \\
\hline
\end{tabular}




\begin{tabular}{|c|c|c|c|c|c|c|c|c|c|c|c|}
\hline Município & cota-BP & Unidade & $\begin{array}{l}\text { Petro- } \\
\text { fácies }\end{array}$ & Fácies & Profund. & Cota & ARC & MATRIZ & CIM & PORO & IGV \\
\hline Matão & 580.00 & PIR-SUP & QA2f & flúvio-eólica & 508.00 & 72.00 & 57.0 & 0.0 & 16.0 & 27.0 & 43.0 \\
\hline Matão & 540.00 & PIR-SUP & QA2C & flúvio-eólica & 428.00 & 112.00 & 77.0 & 0.0 & 23.0 & 0.0 & 23.0 \\
\hline Matão & 540.00 & PIR-SUP & QA2f & flúvio-eólica & 428.00 & 112.00 & 68.3 & 0.0 & 16.7 & 15.0 & 31.7 \\
\hline Orlândia & 660.00 & PIR & FA1c & eólica & 380.00 & 280.00 & 47.0 & 0.0 & 39.0 & 14.0 & 53.0 \\
\hline Orlândia & 660.00 & PIR & FA1p & eólica & 450.00 & 210.00 & 62.2 & 0.0 & 15.8 & 21.9 & 37.7 \\
\hline Pitangueiras & 510.00 & PIR & QA1p & eólica & 682.00 & -172.00 & 69.6 & 0.0 & 3.1 & 27.3 & 30.4 \\
\hline $\begin{array}{c}\text { Presidente } \\
\text { Prudente }\end{array}$ & 420.00 & PIR-SUP & QA2C & flúvio-eólica & 1698.00 & -1278.00 & 65.5 & 0.0 & 29.8 & 4.7 & 34.5 \\
\hline $\begin{array}{c}\text { Presidente } \\
\text { Prudente }\end{array}$ & 420.00 & PIR-SUP & QA2p & flúvio-eólica & 1702.00 & -1282.00 & 74.9 & 0.0 & 5.2 & 19.9 & 25.1 \\
\hline Santa Lúcia & 635.00 & BOT & QA1p & duna & 248.00 & 387.00 & 56.7 & 0.0 & 7.7 & 35.6 & 43.3 \\
\hline $\begin{array}{c}\text { Santa Rosa } \\
\text { Viterbo }\end{array}$ & 780.00 & PIR & FA1p & eólica & 100.00 & 680.00 & 57.5 & 0.0 & 18.5 & 24.0 & 42.5 \\
\hline São Carlos & 850.00 & BOT & QA1p & duna & 234.00 & 616.00 & 62.4 & 0.0 & 9.6 & 28.0 & 37.6 \\
\hline São Carlos & 845.00 & BOT & QA1p & duna & 118.00 & 727.00 & 65.0 & 0.0 & 10.7 & 24.3 & 35.0 \\
\hline Sertãozinho & 560.00 & PIR & QA1p & eólica & 376.00 & 184.00 & 59.8 & 0.0 & 4.5 & 35.7 & 40.2 \\
\hline Sertãozinho & 590.00 & PIR-SUP & QA2C & flúvio-eólica & 304.00 & 286.00 & 70.0 & 0.0 & 20.0 & 10.0 & 30.0 \\
\hline Sertãozinho & 590.00 & PIR-SUP & QA1p & flúvio-eólica & 316.00 & 274.00 & 60.0 & 0.0 & 17.0 & 23.0 & 40.0 \\
\hline Araçatuba & 363.00 & BOT & QA1p & duna & 1116.00 & -745.00 & 73.0 & 0.0 & 7.5 & 19.5 & 27.0 \\
\hline Araçatuba & 363.00 & PIR & FA1p & eólica & 1338.00 & -967.00 & 76.0 & 0.0 & 5.0 & 19.0 & 24.0 \\
\hline Lins & 411.50 & BOT & QA1p & duna & 750.00 & -333.00 & 60.0 & 0.0 & 6.0 & 34.0 & 40.0 \\
\hline Lins & 411.50 & PIR & FA1p & interduna & 949.00 & -532.00 & 73.0 & 0.0 & 10.0 & 17.0 & 27.0 \\
\hline Olímpia & 495.00 & PIR & FA1i & interduna & 1032.20 & -533.20 & 70.0 & 22.0 & 3.0 & 5.0 & 30.0 \\
\hline $\begin{array}{l}\text { Presidente } \\
\text { Epitácio }\end{array}$ & 184.00 & BOT & QA1p & duna & 1625.00 & -1441.00 & 70.8 & 0.0 & 12.6 & 16.6 & 29.2 \\
\hline $\begin{array}{l}\text { Presidente } \\
\text { Epitácio }\end{array}$ & 184.00 & BOT & QA1p & duna & 1732.00 & -1548.00 & 72.0 & 0.0 & 7.0 & 21.0 & 28.0 \\
\hline $\begin{array}{l}\text { Presidente } \\
\text { Epitácio }\end{array}$ & 184.00 & PIR-SUP & $\mathrm{FA} 2 \mathrm{c}$ & flúvio-eólica & 1732.00 & -1548.00 & 70.0 & 0.0 & 29.0 & 1.0 & 30.0 \\
\hline $\begin{array}{l}\text { Presidente } \\
\text { Epitácio }\end{array}$ & 184.00 & PIR & FA2 $\mathrm{i}$ & eólica & 1813.00 & -1629.00 & 82.5 & 0.0 & 15.0 & 2.5 & 17.5 \\
\hline Brotas & 669.00 & BOT & FA1p & duna & 0.00 & 669.00 & 59.3 & 0.0 & 5.7 & 35.0 & 40.7 \\
\hline Analândia & 712.00 & PIR & QA1p & duna/interd & 0.00 & 712.00 & 61.0 & 0.0 & 4.0 & 35.0 & 39.0 \\
\hline
\end{tabular}




\begin{tabular}{|c|c|c|c|c|c|c|c|c|c|c|c|}
\hline Município & cota-BP & Unidade & $\begin{array}{l}\text { Petrofá- } \\
\text { cies }\end{array}$ & Fácies & Profund. & Cota & ARC & MATRIZ & CIM & PORO & IGV \\
\hline Corumbataí & 810.00 & PIR-SUP & QA2p & fluvial & 0.00 & 810.00 & 74.5 & 0.0 & 9.5 & 16.0 & 25.5 \\
\hline Araraquara & 413.00 & BOT & QA1s & duna & 0.00 & 413.00 & 68.0 & 0.0 & 29.5 & 2.5 & 32.0 \\
\hline Angatuba & 702.00 & PIR & $\mathrm{QAb}$ & duna & 0.00 & 702.00 & 57.0 & 0.0 & 42.0 & 1.0 & 43.0 \\
\hline Angatuba & 702.00 & PIR & $\mathrm{Fab}$ & interduna & 0.00 & 702.00 & 56.0 & 0.0 & 32.0 & 12.0 & 44.0 \\
\hline Conchas & 553.00 & PIR & $\mathrm{FAb}$ & duna & 0.00 & 553.00 & 55.0 & 0.0 & 41.3 & 3.7 & 45.0 \\
\hline Conchas & 553.00 & PIR & $F A b$ & interduna & 0.00 & 553.00 & 66.7 & 0.0 & 31.0 & 2.3 & 33.3 \\
\hline Anhembi & 525.00 & PIR & $\mathrm{FAb}$ & duna & 0.00 & 525.00 & 42.0 & 0.0 & 34.0 & 24.0 & 58.0 \\
\hline Anhembi & 525.00 & PIR & $\mathrm{FAb}$ & interduna & 0.00 & 525.00 & 45.7 & 0.0 & 42.3 & 30.0 & 72.3 \\
\hline São Pedro & 546.00 & PIR & FA1p & interduna & 0.00 & 546.00 & 46.3 & 0.0 & 36.7 & 17.0 & 53.7 \\
\hline São Pedro & 546.00 & PIR & FA1p & duna & 0.00 & 546.00 & 62.0 & 0.0 & 18.0 & 20.0 & 38.0 \\
\hline $\begin{array}{c}\text { Santa Maria da } \\
\text { Serra }\end{array}$ & 665.00 & BOT & QA1p & duna & 0.00 & 665.00 & 62.0 & 0.0 & 20.0 & 18.0 & 38.0 \\
\hline $\begin{array}{c}\text { Santa Maria da } \\
\text { Serra }\end{array}$ & 665.00 & BOT & QA1p & interduna & 0.00 & 665.00 & 81.0 & 0.0 & 4.0 & 15.0 & 19.0 \\
\hline Ivaiporã & 1100.00 & PIR-SUP & QA2p & flúvio-eólica & 0.00 & 110.00 & 63.0 & 0.0 & 9.0 & 28.0 & 37.0 \\
\hline
\end{tabular}

\section{Abreviações:}

Coordenadas: LONG - longitude, em graus decimais; LAT - latitude, em graus decimais.

Cota-BP - cota da boca do poço, em metros.

Unidade: BOT - Formação Botucatu, PIR - Formação Pirambóia. PIR-SUP - Formação Pirambóia Superior (flúvio-eólico).

Profund. - Profundidade amostrada, em metros.

ARC - conteúdo de arcabouço, em \%.

MATRIZ - conteúdo de matriz, em \%.

CIM - conteúdo de cimento, em \%.

PORO - conteúdo de poros, em \%.

IGV -volume intergranular, em \%.

Observações: amostras de areia de calha (fragmentos não preservados) não puderam ter os componentes deposicionais e diagenéticos quantificados. 
Tabela 4 - Dados petrográficos (3).

\begin{tabular}{|c|c|c|c|c|c|c|c|c|c|c|c|c|c|c|}
\hline Município & Cota-BP & Unidade & $\begin{array}{l}\text { Petro- } \\
\text { fácies }\end{array}$ & Fácies & Profund. & Cota & Q & $\mathbf{F}$ & LE & LI & $\begin{array}{l}\text { Por } \\
\text { inter }\end{array}$ & $\begin{array}{l}\text { Por_- } \\
\text { intra }\end{array}$ & $\begin{array}{l}\text { Por_ } \\
\text { alv }\end{array}$ & $\begin{array}{l}\text { Por } \\
\text { mold }\end{array}$ \\
\hline Agudos & 620.00 & BOT & QA1p & duna & 178.00 & 442.00 & 96.0 & 2.5 & 1.5 & 0.1 & 38.0 & 3.00 & 3.00 & 0.00 \\
\hline Araçatuba & 410.00 & PIR-SUP & FA2c(p) & flúvio-eólica & 1158.00 & -748.00 & 89.5 & 10.5 & 0.0 & 0.0 & 16.9 & 0.10 & 0.10 & 0.00 \\
\hline Araçatuba & 410.00 & PIR-SUP & QA2p & flúvio-eólica & 1158.00 & -748.00 & 97.0 & 3.0 & 0.1 & 0.1 & 17.1 & 0.90 & 0.90 & 0.00 \\
\hline Araraquara & 640.00 & PIR-SUP & QA1(p) & flúvio-eólica & 296.00 & 344.00 & 85.0 & 4.0 & 11.0 & 0.0 & & 0.00 & 0.10 & 0.00 \\
\hline Araraquara & 640.00 & BOT & QA1(p) & duna & 156.00 & 484.00 & 91.0 & 6.0 & 3.0 & 0.1 & & 0.10 & 0.00 & 0.00 \\
\hline Araraquara & 600.00 & BOT & Qa1(p) & duna & 202.00 & 398.00 & 92.0 & 5.0 & 3.0 & 0.1 & & 0.00 & 0.00 & 0.00 \\
\hline Araraquara & 600.00 & PIR & QA1 $(p, c)$ & flúvio-eólica & 358.00 & 242.00 & 91.0 & 7.0 & 2.0 & 0.1 & & 0.00 & 0.00 & 0.00 \\
\hline Barretos & 560.00 & PIR & QA1p & eólica & 934.00 & -359.00 & 91.0 & 8.0 & 1.0 & 0.1 & 21.0 & 0.01 & 0.01 & 0.00 \\
\hline Barretos & 560.00 & PIR & FA1c & eólica & 934.00 & -359.00 & 90.0 & 10.0 & 0.1 & 0.1 & 8.0 & 0.01 & 0.01 & 0.00 \\
\hline Barretos & 575.00 & BOT & QA1p & eólica & 852.00 & -277.00 & 91.8 & 6.4 & 1.4 & 0.4 & 22.6 & 0.20 & 0.20 & 0.01 \\
\hline Barretos & 575.00 & BOT & QA1p & eólica & 890.00 & -315.00 & 90.6 & 6.8 & 1.8 & 0.8 & 22.1 & 0.50 & 0.50 & 0.01 \\
\hline Barretos & 575.00 & PIR-SUP & QA2C & flúvio-eólica & 910.00 & -335.00 & 88.0 & 7.6 & 3.2 & 1.2 & 5.4 & 0.01 & 0.01 & 0.00 \\
\hline Barretos & 575.00 & PIR-SUP & QA2C & flúvio-eólica & 928.00 & -353.00 & 96.4 & 2.4 & 1.1 & 0.1 & 3.2 & 0.01 & 0.01 & 0.00 \\
\hline Barretos & 575.00 & PIR & QA1p & eólica & 952.00 & -377.00 & 91.6 & 7.3 & 1.0 & 0.1 & 25.2 & 0.01 & 0.01 & 0.00 \\
\hline Barretos & 575.00 & PIR & QA1C & eólica & 952.00 & -377.00 & 95.6 & 3.0 & 1.3 & 0.1 & 0.0 & 0.70 & 0.01 & 0.00 \\
\hline Barretos & 575.00 & PIR & FA1i & eólica & 948.00 & -373.00 & 83.0 & 17.0 & 0.1 & 0.1 & 15.0 & 3.00 & 3.00 & 0.01 \\
\hline Barretos & 575.00 & PIR & FA1p & eólica & 968.00 & -393.00 & 87.7 & 10.4 & 0.8 & 1.1 & 29.5 & 0.80 & 0.80 & 0.01 \\
\hline Barretos & 575.00 & PIR & QA1c & eólica & 968.00 & -393.00 & 92.1 & 6.4 & 0.9 & 0.6 & 0.0 & 2.40 & 0.20 & 0.00 \\
\hline Barrinha & 520.00 & PIR-SUP & QA2C & flúvio-eólica & 394.00 & 126.00 & 92.7 & 6.3 & 0.6 & 0.4 & 0.0 & 3.20 & 0.03 & 0.00 \\
\hline Barrinha & 520.00 & PIR-SUP & QA2C & fluvial & 394.00 & 126.00 & 91.5 & 8.0 & 0.4 & 0.1 & 12.4 & 5.10 & 0.70 & 0.00 \\
\hline Batatais & 700.00 & BOT & FA1p & duna & 124.00 & 579.50 & 86.9 & 12.9 & 0.2 & 0.0 & 25.8 & 1.20 & 1.20 & 0.00 \\
\hline Batatais & 700.00 & PIR-SUP & QA2p & flúvio-eólica & 168.00 & 535.50 & 94.9 & 4.3 & 0.8 & 0.0 & 21.8 & 0.01 & 0.01 & 0.00 \\
\hline Batatais & 700.00 & PIR & QA1p & eólica & 254.00 & 449.50 & 92.8 & 5.7 & 1.5 & 0.1 & 30.1 & 0.01 & 0.01 & 0.00 \\
\hline Batatais & 840.00 & BOT & QA2s & eólica & 330.00 & 510.00 & 94.5 & 4.0 & 1.0 & 0.5 & 0.0 & 0.70 & 0.70 & 0.00 \\
\hline Batatais & 840.00 & PIR & QA2c(p) & eólica & 496.00 & 344.00 & 92.5 & 6.9 & 1.1 & 0.6 & 11.2 & 2.80 & 1.20 & 1.60 \\
\hline Bauru & 510.00 & BOT & QA1c & duna & 78.00 & 432.00 & 93.3 & 5.6 & 0.6 & 0.5 & 0.0 & 1.20 & 0.00 & 0.00 \\
\hline Bauru & 533.50 & PIR-SUP & QA2(p) & flúvio-eólica & 290.00 & 243.50 & 96.0 & 4.0 & 0.1 & 0.1 & 7.0 & 0.01 & 0.01 & 0.00 \\
\hline Catanduva & 500.00 & BOT & QA1 & duna & 476.00 & 24.00 & 92.0 & 5.0 & 3.0 & 0.1 & & & $\mathrm{pr}$ & \\
\hline Catanduva & 500.00 & PIR-SUP & QA1 & eólica & 668.00 & -168.00 & 90.0 & 9.0 & 1.0 & 0.1 & & & pr & \\
\hline Dois Córregos & 722.00 & PIR & QA1p & eólica & 552.00 & 170.00 & 91.7 & 7.1 & 0.6 & 0.6 & 33.1 & 0.90 & 0.00 & 0.60 \\
\hline
\end{tabular}




\begin{tabular}{|c|c|c|c|c|c|c|c|c|c|c|c|c|c|c|}
\hline Município & Cota-BP & Unidade & $\begin{array}{l}\text { Petro- } \\
\text { fácies }\end{array}$ & Fácies & Profund. & Cota & Q & $\mathbf{F}$ & LE & LI & $\begin{array}{l}\text { Por_ } \\
\text { inter }\end{array}$ & $\begin{array}{l}\text { Por_- } \\
\text { intra } \\
\end{array}$ & $\begin{array}{l}\text { Por__ } \\
\text { alv }\end{array}$ & \begin{tabular}{|l} 
Por \\
mold \\
\end{tabular} \\
\hline Fernandópolis & 436.00 & PIR & FA1p & eólica & 1598.00 & -1162.00 & 79.4 & 17.3 & 1.9 & 1.4 & 26.6 & 1.20 & 1.20 & 0.01 \\
\hline Fernandópolis & 436.00 & PIR & FA2p & eólica & 1598.00 & -1162.00 & 88.4 & 10.0 & 1.6 & 0.1 & 24.8 & 2.20 & 2.20 & 0.01 \\
\hline Ibaté & 840.00 & BOT & QA1(p) & duna & 234.00 & 606.00 & 94.0 & 6.0 & 0.1 & 0.1 & & & $\mathrm{pr}$ & \\
\hline Macatuba & 500.00 & BOT & QA1p & duna & 156.00 & 344.00 & 94.0 & 4.0 & 2.0 & 0.1 & 35.9 & 0.10 & 0.10 & 0.00 \\
\hline Matão & 580.00 & BOT & QA2C & duna & 446.00 & 134.00 & 94.0 & 3.0 & 3.0 & 0.1 & 0.0 & 0.10 & 0.10 & 0.00 \\
\hline Matão & 580.00 & BOT & QA1C & duna & 492.00 & 88.00 & 96.0 & 4.0 & 0.1 & 0.1 & 10.9 & 0.10 & 0.10 & 0.00 \\
\hline Matão & 580.00 & PIR-SUP & QA1f & flúvio-eólica & 508.00 & 72.00 & 93.6 & 6.4 & 0.1 & 0.1 & 16.7 & 3.50 & 2.10 & 1.40 \\
\hline Matão & 580.00 & PIR-SUP & QA2f & flúvio-eólica & 508.00 & 72.00 & 93.0 & 3.0 & 4.0 & 0.0 & 15.9 & 0.10 & 0.10 & 0.00 \\
\hline Matão & 540.00 & PIR-SUP & QA2C & flúvio-eólica & 428.00 & 112.00 & 95.0 & 3.0 & 2.0 & 0.0 & 0.0 & 0.00 & 0.00 & 0.00 \\
\hline Matão & 540.00 & PIR-SUP & QA2f & flúvio-eólica & 428.00 & 112.00 & 92.2 & 5.4 & 2.4 & 0.0 & 14.0 & 1.00 & 0.70 & 0.00 \\
\hline Orlândia & 660.00 & PIR & FA1c & eólica & 380.00 & 280.00 & 79.0 & 19.0 & 0.1 & 2.0 & 10.0 & 4.00 & 2.00 & 2.00 \\
\hline Orlândia & 660.00 & PIR & FA1p & eólica & 450.00 & 210.00 & 82.3 & 13.7 & 2.0 & 2.0 & 19.9 & 2.00 & 0.10 & 2.00 \\
\hline Pitangueiras & 510.00 & PIR & QA1p & eólica & 682.00 & -172.00 & 95.2 & 3.3 & 1.5 & 0.1 & 26.0 & 1.30 & 0.30 & 1.00 \\
\hline $\begin{array}{l}\text { Presidente } \\
\text { Prudente }\end{array}$ & 420.00 & PIR-SUP & QA2C & flúvio-eólica & 1698.00 & -1278.00 & 87.0 & 4.0 & 7.0 & 2.0 & 0.0 & 4.70 & 0.10 & 0.00 \\
\hline $\begin{array}{l}\text { Presidente } \\
\text { Prudente }\end{array}$ & 420.00 & PIR-SUP & QA2p & flúvio-eólica & 1702.00 & -1282.00 & 87.1 & 7.9 & 2.9 & 2.1 & 19.8 & 0.10 & 0.10 & 0.00 \\
\hline Santa Lúcia & 635.00 & BOT & QA1p & duna & 248.00 & 387.00 & 91.7 & 5.3 & 0.3 & 2.7 & 35.5 & 0.10 & 0.10 & 0.00 \\
\hline $\begin{array}{c}\text { Santa Rosa } \\
\text { Viterbo }\end{array}$ & 780.00 & PIR & FA1p & eólica & 100.00 & 680.00 & 88.2 & 10.0 & 1.7 & 0.1 & 18.0 & 6.00 & 0.50 & 5.50 \\
\hline São Carlos & 850.00 & BOT & QA1p & duna & 234.00 & 616.00 & 90.3 & 7.0 & 2.0 & 0.7 & 26.4 & 1.60 & 0.40 & 1.20 \\
\hline São Carlos & 845.00 & BOT & QA1p & duna & 118.00 & 727.00 & 94.3 & 5.3 & 0.3 & 0.1 & 23.0 & 1.00 & 1.00 & 0.00 \\
\hline $\begin{array}{c}\text { São Jose Rio } \\
\text { Preto }\end{array}$ & 545.00 & BOT & QA1 $(p)$ & duna & 848.00 & -303.00 & 92.0 & 3.0 & 5.0 & 0.1 & & $\mathrm{pr}$ & $\mathrm{pr}$ & \\
\hline $\begin{array}{c}\text { São José Rio } \\
\text { Preto } \\
\end{array}$ & 545.00 & PIR-SUP & $\mathrm{QA1}(\mathrm{c}, \mathrm{p})$ & flúvio-eólica & 1024.00 & -479.00 & 94.0 & 5.0 & 1.0 & 0.0 & & 0.00 & 0.00 & \\
\hline $\begin{array}{c}\text { São José Rio } \\
\text { Preto }\end{array}$ & 545.00 & PIR & $\mathrm{FA1}(\mathrm{c}, \mathrm{p})$ & eólica & 1136.00 & -591.00 & 81.0 & 16.0 & 3.0 & 0.1 & & $\mathrm{pr}$ & $\mathrm{pr}$ & \\
\hline Sertãozinho & 560.00 & PIR & QA1p & eólica & 376.00 & 184.00 & 94.6 & 5.0 & 0.4 & 0.0 & 35.6 & 0.10 & 0.10 & 0.01 \\
\hline Sertãozinho & 590.00 & PIR-SUP & QA2C & flúvio-eólica & 304.00 & 286.00 & 94.9 & 3.0 & 2.0 & 0.1 & 9.5 & 0.50 & 0.10 & 0.00 \\
\hline Sertãozinho & 590.00 & PIR-SUP & QA1p & flúvio-eólica & 316.00 & 274.00 & 94.0 & 3.0 & 3.0 & 0.1 & 22.9 & 0.10 & 0.10 & 0.00 \\
\hline Votuporanga & 520.00 & BOT & QA1(p) & duna & 1198.00 & -678.00 & 96.0 & 2.0 & 2.0 & 0.0 & & 0.00 & 0.00 & 0.00 \\
\hline Votuporanga & 520.00 & PIR-SUP & QA2(p,c) & flúvio-eólica & 1316.00 & -796.00 & 96.0 & 2.0 & 3.0 & 0.0 & & 0.00 & 0.00 & 0.00 \\
\hline
\end{tabular}




\begin{tabular}{|c|c|c|c|c|c|c|c|c|c|c|c|c|c|c|}
\hline Município & Cota-BP & Unidade & $\begin{array}{l}\text { Petro- } \\
\text { fácies }\end{array}$ & Fácies & Profund. & Cota & $\mathbf{Q}$ & $\mathbf{F}$ & LE & LI & $\begin{array}{l}\text { Por } \\
\text { inter }\end{array}$ & $\begin{array}{l}\text { Por } \\
\text { intra }\end{array}$ & $\begin{array}{l}\text { Por_ } \\
\text { alv }\end{array}$ & \begin{tabular}{|l} 
Por_ \\
mold \\
\end{tabular} \\
\hline Votuporanga & 520.00 & PIR-SUP & $\mathrm{QA} 2(\mathrm{p}, \mathrm{c})$ & fluvial & 1340.00 & -820.00 & 93.0 & 2.0 & 5.0 & 0.0 & & 0.00 & 0.00 & 0.00 \\
\hline Araçatuba & 363.00 & BOT & QA1p & duna & 1116.00 & -745.00 & 89.5 & 8.0 & 2.5 & 0.1 & 19.3 & 0.40 & 0.40 & 0.00 \\
\hline Araçatuba & 363.00 & PIR-SUP & QA2 & flúvio-eólica & 1173.00 & -802.00 & 70.0 & 2.0 & 28.0 & 0.0 & & & & \\
\hline Araçatuba & 363.00 & PIR & FA1p & eólica & 1338.00 & -967.00 & 84.0 & 11.0 & 4.0 & 1.0 & 18.9 & 0.10 & 0.10 & 0.00 \\
\hline Lagoa Azul & 420.00 & BOT & QA1(p,c) & duna & 1317.00 & -897.00 & 98.0 & 1.0 & 1.0 & 0.0 & & 0.00 & 0.00 & 0.00 \\
\hline Lagoa Azul & 420.00 & PIR-SUP & QA2(p,c) & flúvio-eólica & 1341.00 & -921.00 & 97.0 & 0.1 & 3.0 & 0.0 & & 0.00 & 0.00 & 0.00 \\
\hline Lins & 411.50 & BOT & QA1p & duna & 750.00 & -333.00 & 90.0 & 9.0 & 1.0 & 0.1 & 31.0 & 3.00 & 3.00 & 0.01 \\
\hline Lins & 411.50 & PIR & FA1p & interduna & 949.00 & -532.00 & 75.0 & 12.0 & 10.0 & 3.0 & 15.2 & 1.80 & 1.70 & 0.00 \\
\hline Olímpia & 495.00 & PIR & FA1i & interduna & 1032.20 & -533.20 & 85.0 & 13.0 & 1.0 & 1.0 & 2.3 & 1.20 & 0.20 & 0.00 \\
\hline $\begin{array}{l}\text { Presidente } \\
\text { Epitácio }\end{array}$ & 184.00 & BOT & QA1p & duna & 1625.00 & -1441.00 & 94.0 & 5.4 & 0.3 & 0.3 & 16.3 & 0.30 & 0.30 & 0.00 \\
\hline $\begin{array}{l}\text { Presidente } \\
\text { Epitácio }\end{array}$ & 184.00 & BOT & QA1p & duna & 1732.00 & -1548.00 & 91.7 & 5.5 & 2.8 & 0.1 & 19.9 & 0.10 & 0.10 & 0.00 \\
\hline $\begin{array}{l}\text { Presidente } \\
\text { Epitácio }\end{array}$ & 184.00 & PIR-SUP & FA2c & flúvio-eólica & 1732.00 & -1548.00 & 85.7 & 11.4 & 2.9 & 0.1 & 20.9 & 0.10 & 0.10 & 0.00 \\
\hline $\begin{array}{l}\text { Presidente } \\
\text { Epitácio }\end{array}$ & 184.00 & PIR & FA2i & eólica & 1813.00 & -1629.00 & 75.2 & 18.8 & 5.0 & 1.0 & 2.5 & 0.01 & 0.01 & 0.00 \\
\hline Brotas & 669.00 & BOT & FA1p & duna & 0.00 & 669.00 & 89.7 & 10.7 & 0.5 & 0.1 & 34.60 & 0.40 & 0.40 & 0.01 \\
\hline Analândia & 712.00 & PIR & QA1p & $\begin{array}{c}\text { duna/ } \\
\text { interduna }\end{array}$ & 0.00 & 712.00 & 94.8 & 5.0 & 0.1 & 0.1 & 90.10 & 9.80 & 0.10 & 9.80 \\
\hline Corumbataí & 810.00 & PIR-SUP & QA2p & fluvial & 0.00 & 810.00 & 83.5 & 4.0 & 12.0 & 0.5 & 15.90 & 0.10 & 0.10 & 0.00 \\
\hline Araraquara & 413.00 & BOT & QA1s & duna & 0.00 & 413.00 & 93.9 & 3.0 & 3.0 & 0.1 & 2.40 & 0.10 & 0.10 & 0.00 \\
\hline Angatuba & 702.00 & PIR & QAb & duna & 0.00 & 702.00 & 88.9 & 9.3 & 1.2 & 0.6 & 1.00 & 0.01 & 0.01 & 0.00 \\
\hline Angatuba & 702.00 & PIR & $F A b$ & interduna & 0.00 & 702.00 & 87.3 & 11.9 & 0.7 & 0.1 & 11.00 & 1.00 & 1.00 & 0.00 \\
\hline Conchas & 553.00 & PIR & $F A b$ & duna & 0.00 & 553.00 & 87.3 & 12.1 & 0.3 & 0.3 & 3.70 & 0.01 & 0.01 & 0.00 \\
\hline Conchas & 553.00 & PIR & $\mathrm{FAb}$ & interduna & 0.00 & 553.00 & 82.4 & 17.0 & 0.5 & 0.1 & 2.00 & 0.30 & 0.30 & 0.00 \\
\hline Anhembi & 525.00 & PIR & $\mathrm{FAb}$ & duna & 0.00 & 525.00 & 85.5 & 14.3 & 0.1 & 0.1 & 23.00 & 1.00 & 0.70 & 0.01 \\
\hline Anhembi & 525.00 & PIR & $\mathrm{FAb}$ & interduna & 0.00 & 525.00 & 86.1 & 13.1 & 0.3 & 0.5 & 25.50 & 0.50 & 0.01 & 0.50 \\
\hline São Pedro & 546.00 & PIR & FA1p & interduna & 0.00 & 546.00 & 85.7 & 11.5 & 1.4 & 1.4 & 10.70 & 6.30 & 3.00 & 1.30 \\
\hline São Pedro & 546.00 & PIR & FA1p & duna & 0.00 & 546.00 & 86.0 & 10.0 & 2.0 & 2.0 & 12.00 & 8.00 & 4.00 & 4.00 \\
\hline
\end{tabular}




\begin{tabular}{|c|c|c|c|c|c|c|c|c|c|c|c|c|c|c|}
\hline Município & Cota-BP & Unidade & $\begin{array}{l}\text { Petro- } \\
\text { fácies }\end{array}$ & Fácies & Profund. & Cota & Q & $\mathbf{F}$ & LE & LI & $\begin{array}{l}\text { Por_ } \\
\text { inter }\end{array}$ & $\begin{array}{l}\text { Por_- } \\
\text { intra }\end{array}$ & $\begin{array}{l}\text { Por_- } \\
\text { alv }\end{array}$ & $\begin{array}{l}\text { Por } \\
\text { mold }\end{array}$ \\
\hline $\begin{array}{c}\text { Santa Maria } \\
\text { da Serra }\end{array}$ & 665.00 & BOT & QA1p & duna & 0.00 & 665.00 & 90.9 & 7.0 & 2.0 & 0.1 & 15.30 & 2.70 & 0.90 & 1.80 \\
\hline $\begin{array}{c}\text { Santa Maria } \\
\text { da Serra }\end{array}$ & 665.00 & ВОТ & QA1p & interduna & 0.00 & 665.00 & 95.9 & 3.0 & 0.1 & 1.0 & 12.90 & 2.10 & 0.20 & 1.90 \\
\hline Ivaiporã & 1100.00 & PIR-SUP & QA2p & flúvio-eólica & 0.00 & 1100.00 & 93.9 & 0.1 & 6.0 & 0.0 & 26.6 & 1.40 & 0.00 & 1.10 \\
\hline
\end{tabular}

\section{Abreviações:}

Cota-BP - cota da boca do poço, em metros.

Unidade: BOT - Formação Botucatu, PIR - Formação Pirambóia. PIR-SUP - Formação Pirambóia Superior (flúvio-eólico).

Profund. - Profundidade amostrada, em metros.

$\mathrm{Q}$ - conteúdo de quartzo, em \%.

$\mathrm{F}$ - conteúdo de feldspato, em \%.

LE - conteúdo de fragmentos líticos estáveis, em \%.

LI - conteúdo de fragmentos líticos instáveis, em \%.

Por_inter - porosidade intergranular, em \%.

Por intra - porosidade intragranular, em \%.

Por_alv - porosidade alveolar, em \%.

Por_mold - porosidade móldica, em \%.

Observações: amostras de areia de calha (fragmentos não preservados) não puderam ter os componentes diagenéticos quantificados; por isto anotou-se apenas a presença de porosidade secundária (anotações pr). 